\title{
HISTORY OF THE ART \\ DF CUTTING IN ENGLAND
}

EDWARD B. GILES. 
8. 


$$
7+3
$$


Cooper-Hewitt Museum Library

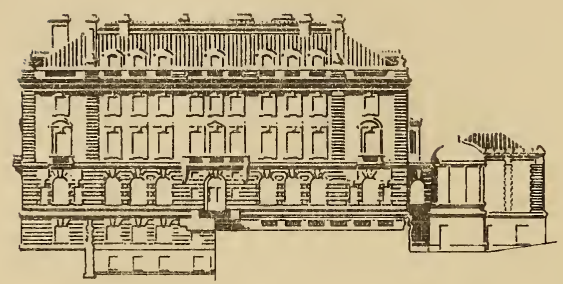

Smithsonian Institution Libraries 
Meldred.Moars 


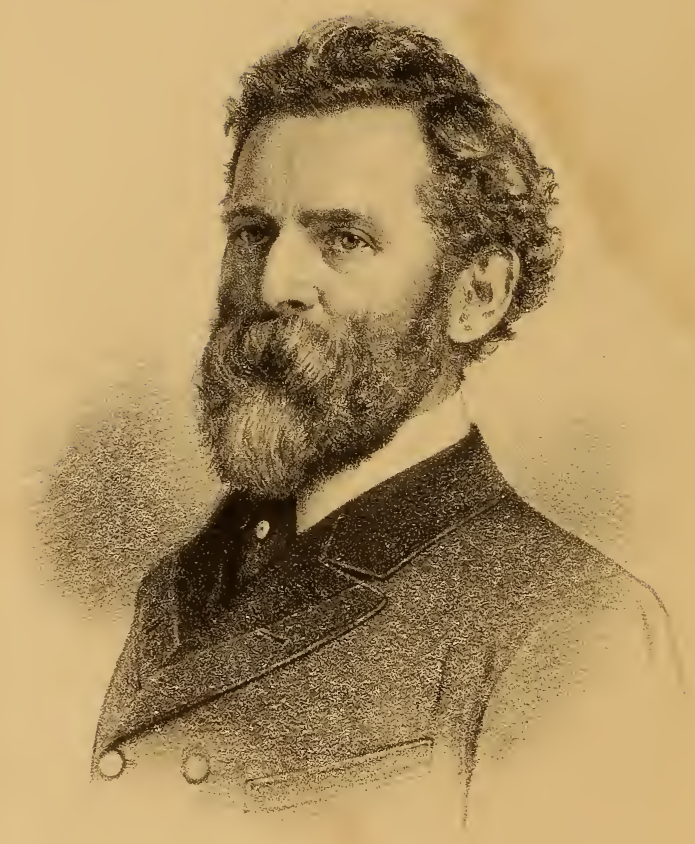

(2) 


\section{THE HISTORY \\ OF THE}

\section{ART OF CUTT
IN ENGLAND;}

PRECEDED BY

A SKETCH

OF THE

HISTORY OF ENGLLSH COSTUMES.

ILLUSTRATED BY

TWENTY-ONE ILLUSTRATIONS, NINE PLATES OF DIAGRAMS,

AND A

LITHOGRAPHIC PORTRAIT OF THE AUTHOR.

By EDWARD B. Giver ${ }_{1,1}^{\text {cwys, }}$

Twenty-three years Editor of the "West-End Gazette," and Co-Author of the "West-End System of Cutting."

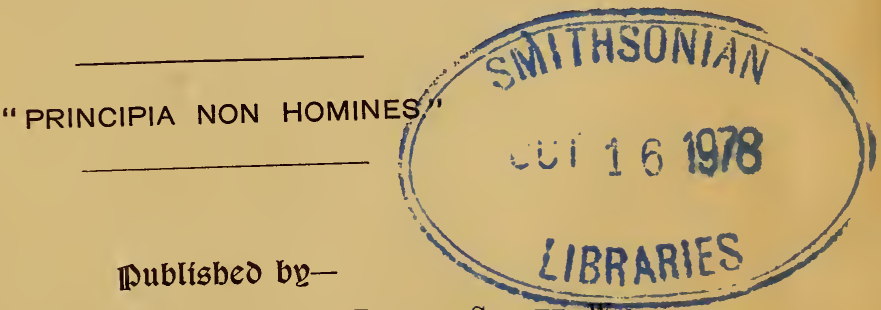

F. T. PREWETT, 23, WARwick Street, Regent Street, W.;

Messrs. KENT \& Co., Paternoster Row;

JNO. J. MITCHELL \& Co., 280, Broadway, New York.

LONDON, 1887. 


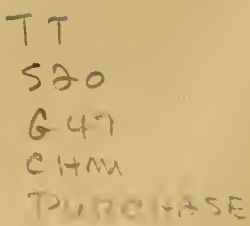

Kenny \& Co., Printers,

25, Camden Road, London, N.W. 
THIS WORK

IS DEDICATED TO MY FRIEND AND CO-AUTHOR,

MR. F. T. PREWETT,

AS A

SLIGHT TESTIMONY OF THE AUTHOR'S PERSONAL ESTEEM

AND HIGH APPRECIATION OF

HIS LABOURS FOR THE BENEFI' OF TAILORS

AND THE ADVANCEMENT AND ELEVATION OF THE TRADE. 



\section{PREFACE.}

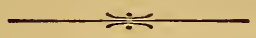

\section{Gentle Reader,-}

It is due to you at least to explain why the Author of this work was induced to write it, and to justify in some measure, however small, its addition to the Literature of our Trade. In a course of reading works on Cutting, I met with a German work containing "The History of the Art of Cutting in Europe," by H. Klemm, jun. It occurred to me that if I translated this history it would be interesting and instructive to the readers of the "West-End Gazette." I also had the pleasure to read a work in French, by M. Canneva, relating to the same subject. This I translated and published through the same medium as the former.

I felt deeply that some injustice had been done to our old English Authors, from the meagre list of their names and works given by Herr Klemm. This arose most probably from the imperfect knowledge of the writer of the names of our Old Authors, and not from any desire to slight them. However, I was convinced that it was the duty of some one to endeavour to make a permanent record of their names and works; and as no one else could be induced to undertake the task of writing "The History of the Art of Cutting in England," I determined to make the attempt myself. The materials have been more difficult to collect, and the labour has been greater than I anticipated; still, if the duty has been in some measure accomplished I shall be amply repaid for my efforts.

The sketch of the History of Costume I hope will be interesting, and of some service to tailors, because it treats of costumes especially, where it is instructive to them, and assuredly this information cannot be obtained anywhere else in so compact a form. In each case the most reliable authorities 
have been consulted, so that the statements may be absolutely relied upon. I have purposely omitted any reference to ladies' attire, or to the various changes in fashion in armour, wigs, hats, \&c., \&c., which either the change of circumstances dictated, or the folly or caprice of youth originated. Those who desire information on these subjects will find it in works which are referred to. I am afraid that some repetitions will be found, but these have scarcely been avoidable, from the fragmentary manner in which the greater part of the work has been written.

I am fully conscious of my inability to do ample justice to these subjects, and I say this frankly and without any absurd affectation of modesty; so wherever I fail, I beg you will consider it a deficiency of capacity and opportunity, rather than a lack of will.

E. B. G. 


\section{INTRODUCTION.}

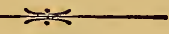

"The History of the Art of Cutting in England" has not yet been written. Our old authors, who have "lived, died, and had their being," have not been noticed, nor their labours recorded, beyond their own works. It is certainly full time that their names and works were rescued from possible oblivion, that we should testify our gratitude for the unselfishness of their labours, and make some acknowledgment of the benefits we have derived from their works.

I have endeavoured in the following pages to collect, arrange, and notice some of the more prominent features of their varied works, and have illustrated with diagrams the more important. I make no pretence nor claim to completeness, only as far as I have been able to gather the materials. Still, I have had the generous assistance of several kind friends, whose kindness I desire to acknowledge and record, amongst whom I may mention Mr. S. RAwLEY and Mr. J. Blomfield, of Rayleigh, Essex, without whose aid my labours would at least have been considerably increased.

It is exceedingly interesting to note that the earliest known work on Cutting is written in Spanish, and that we possess a copy in our library at the South Kensington Museum. I also discovered an earlier work, by a French author, than is mentioned by the French historian, M. Canneva, and this is in the library of the Royal Society of British Architects. The work by the Society of Adepts, which I found in the British Museum, is without doubt the first of the kind published in England. Between this and the works of Hearn, Cook, and Goulding, I think there must have been Systems which were taught, if not written and published, although I have not been able to trace or find any. Some future historian may possibly be able to supply this void, if it really exists. 
I have been much astonished at the loss of time and thought incurred by authors and inventors, from a want of knowledge of the labours of those who had preceded them. I have a faint hope that this work will furnish enquirers with information that may be useful to them, and prevent them using some exploded theories or discarded useless inventions; still leaving them "fancy free to wander forth 'midst fresh fields and pastures new."

I have endeavoured to give a complete sketch of the History of English Costume from a Tailor's point of view, and have taken considerable care that the information should be reliable. Such Illustrations have been added as cannot fail to convey a clearer idea than I could hope to give with words alone.

This work has occupied a great part of my leisure hours during these last ten years. I may frankly confess that if I had had an adequate idea of the labour involved, I should have been deterred from making the attempt. Still, it has been, in a great measure, a labour of love; and if I have been the means of conveying some interesting facts to the knowledge of the trade, and preserving the memories green of some departed trade worthies, I shall be amply compensated. But if not, the self-consciousness that I have made an effort, that "something has been accomplished, something done," lends a charm and contentment to the mind, produces a peace and satisfaction that passeth all understanding, and satisfies the demands of a sensitive conscience.

London, 1887. 


\section{HISTOR Y}

OF THE

\section{ART OF CUTTING IN ENGLAND.}

\section{PART I.}

\section{AN INTRODUCTORY SKETCH OF ENGLISH COSTUME.}

The origin of the Art of Cutting is involved in obscurity. Any attempt to discover its continual progress must necessarily be imperfect, from the paucity of materials and the dearth of reliable information obtainable for the purpose. Still, such an endeavour (incomplete though it may be) must possess considerable interest for the thoughtful student, and afford a reliable basis for a future and more extended research.

Before, however, commencing this record, I have concluded, after mature consideration, that additional interest would be created, and its usefulness increased, if it were preceded by a concise narrative of the origin of various garments and the different changes which have taken place in this department of English Costume.

Such an intimate relation exists between the Tailor and the garment which he fashions that I can scarcely treat of the various methods he uses in his art without reflecting on the kinds of costume he is required to produce; therefore, some account of the changes in costume will form an appropriate and valuable introduction to this subject, and at the same time, by affording information which is not obtainable in so concise a form, it may both interest and instruct.

There is a vast difference between the period when the armourer forged suits of armour, or implements of the chase, and that when the tailor made suits of velvet richly embroidered or trimmed with lace. The one reminds us of a rude and rough time when the chase was a man's principal pastime, and war his 
noblest occupation; the other is associated with a period of luxury, frivolity, splendour, and vice. These external signs clearly indicate two different and opposite eras of civilisation and progress. If other periods do not afford so marked a contrast, still the intelligent reader will be able to note the development in the physical and social conditions of the people, and the gradual progress of civilisation as shewn by the costumes of successive epochs in English history.

It would extend far beyond the scope of my purpose to make more than a passing allusion to prehistoric times, when the fishbone needle was used by the primeval tailors to sew the skin coverings of our primordial ancestors. I intend merely to indicate the period when our forefathers-

\section{"Their leaves}

They gathered broad as Amazonian Targe

And with what skill they had, together sewed

To gird their waist."

And I shall only have occasion to refer incidentally to the costumes of the ancients for the purpose of illustration or comparison. Neither shall I attempt to describe regal robes or knightly armour, nor ladies' costumes, styles of head dress or foot gear which necessity or fashion had originated.

Those who desire to possess a more complete and extended knowledge of this subject should study "Dress and Habits of the people of England," by Joseph Strutt; "The History of Costume," by J. R. Planché ; "Manners and Customs of the English Nation;" and Fairholt's "Costumes in England." I simply propose to treat of English Costume where it is interesting or instructive to tailors, with the view of forming a connecting link between the Tailor's Art of the past and the present.

The study of costume was formerly considered to be unnecessary, useless, or even a waste of valuable time; but a more mature knowledge has impelled Artists to depict with greater accuracy the dresses of any period they may be illustrating. Managers of theatres have made considerable progress in the study of costume, as they now feel it is imperative in ligh-class dramatic representations to present their dramatis persona clothed in the actual dress of the period in which the action is supposed to take place. The absurdity of representing on the stage the heroes of antiquity clothed in modern costume is patent to the multitude, and it would now be considered a great breach of historical propriety to pourtray an English Statesman or Warrior robed in a Roman toga. Some able remarks on this subject by a modern author are so apposite as to merit quotation:

"The taste for a correct conception of the arms and habits of 
our ancestors has of late years rapidly diffused itself throughout Europe. The historian, the poet, the novelist, the painter, and the actor have discovered in attention to costume a new spring of information and a fresh source of effect. Its study, embellished by picture and enlivened by anecdote, soon becomes interesting even to the young and careless reader; and at the same time that it sheds light upon manners and rectifies dates, stamps the various events and eras in the most natural and vivid colours indelibly on the memory.

"Of those who affect to ridicule the description of a doublet, or to deny the possibility of assigning the introduction of any particular habit to any particular period (and some have done so in print who should have known better), we would only inquire what criticism they would pass upon the painter who should represent Július Cæsar in a frock-coat, cocked hat, and Wellington trousers? nor will we admit this to be an extreme case, for how lately have the heroes and sages of Greece and Rome strutted upon the stage in flowing perukes and gold-laced waistcoats?

'What shook the stage and made the people stare?-

Cato's long wig, flowered gown, and lacker'd chair.'

And is the representing Paris in a Roman dress, as was done by West, the President of the Royal Academy, to be considered a more venial offence, because it is more picturesque and less capable of detection by the general spectator?"

It has been the usual practice, when describing the costumes of a period, to consider principally, if not solely, the robes of monarchs, the vestments of the clergy, and the uniform of soldiers; the garb of the trading classes, and the clothing of the common people being considered as of no moment, or at least of very little importance. In my opinion the manners, customs, and even the dress of the trading and working classes, are equally full of interest and value, as they give us an insight into the prevailing habits, occupations, and social condition of people whose lives were passed in obscurity, and whom historians have formerly felt it unnecessary or unworthy to describe or dwell upon.

If a correct knowledge of the costume of our ancestors is now felt to be absolutely necessary to the historian or artist who wishes to depict the events of the past, it is scarcely conceivable that this subject will be devoid of interest to those who are at present engaged in designing or manufacturing the clothing of their fellow citizens.

I hope it will be clearly understood that the purpose of the following remarks is to give a concise narrative of English costume, so far as it concerns the art and trade of tailors, therefore 
all extraneous matters, such as ladies' dress, armour, shoes, \&c., will be omitted.

As no similar attempt has been made, and as the information cannot be obtained in so compact a form, it is hoped that this effort will be acceptable to the young and aspiring minds in our profession. With this view the best and most reliable authorities have been consulted for the purpose of rendering the information perfectly trustworthy and authentic.

The necessity of man's protecting his body from the inclemency of the elements would naturally suggest itself as one of the primary reasons for his providing some kind of clothing. The most ready, useful, and natural covering that he could procure was the skin of animals; these he converted to his use by forming them into garments which would afford warmth and comfort to his person. The skins were also dried and used as a protection to his feet; and still later on in the world's history, they were made into shields for his body to ward off the attacks of ferocious animals, or the weapons of his enemies.

The long wool of certain animals was, after passing through various processes, woven into a fabric which was afterwards formed into garments for his use or adornment. The resources of the vegetable kingdom were also found suitable to his wants, the fibre of the flax plant supplying material for the distaff.

After his primary wants had been-supplied, without much lapse of time there arose other demands. It was found requisite to distinguish the social position of individuals, and this was most readily effected by assigning certain colours or emblematic ornaments to the different grades of society. It was also necessary to distinguish the sex, to protect, and even add to the beauty of the person. The wild flowers, laving in the summer's sun, the precious ornaments with which Nature has so bountifully decked the earth, those "things of beauty and joy for ever," attracted the attention of the more impressionable sex, by the splendour of their colours, the beauty of their forms, and the fragrance of their perfumes. To adapt them as an ornament was the most simple and spontaneous act. The pleasure which colours afforded to the senses stimulated art to endeavour to imitate or reproduce their various beautiful hues.

As man progressed in intelligence, and increased in possessions, a desire for greater comfort and even luxury arose. The product of the silkworm was found available, and made conducive to the splendour of his attire. The wool of the cotton plant was also made contributory to his many requirements. Which of these two last-named materials was first discovered and adapted for man's use it is impossible to determine, as their origin and first application are buried in darkness and obscurity.

Another advance in the art of dress was then made. As 
apparel of some kind had to be worn in war as well as in peace, a variety of form was found necessary to adapt to those conditions, as well as for the adornment of the person. Thus the art of the tailor, rude or unskilled as it must have been in its primitive conception, soon developed itself, and formed an early indication of man's status in art, and was an essential instrumentality in the progress of civilisation.

The necessary garments of mankind, as Mr. Strutt has truly observed, were never many: one adjusted to the body, reaching to the knee or mid-leg, for the men, to the ankle for the women; another ample enough to clothe the whole person in "inclement weather." These two, remarks Mr. Planché, with or without some protection to the feet, comprised the whole of the clothing of many millions of human beings in pre-historic times, and under innumerable names, have, with very few additions, descended, however altered in form or material, to the present day. The first of these two garments was the tunic, adapted from the Greeks by the Romans. The nomenclature has now re-appeared among us, as the name of the military coat. In his "Cyclopædia of Costume," Planché adds, "I have said that millions of men and women in these early ages were content with two or three garments of a similar description, whatever their name or the material of which they were composed; there were, however, other millions whose costume at the same period presented an important addition so markedly characteristic of a distinct origin that it deserves, I think, more consideration than it seems to have hitherto received. This addition was the clothing of the legs, independently and completely down to the feet, a custom invariably observed by them through all their migrations, unaffected by change of climate or form of government. In brief, the nations of the ancient world might fairly be divided into two great groups or classes-the trousered and the untrousexed. Amongst the latter were the Greeks and the Romans, deriving their origin, as it appears to be generally acknowledged, from the barelegged Egyptians; while two great branches of the Scythic or Northern Asiatic family, which had overrun Europe and colonised the south of Britain long previous to the Roman invasion, viz., the Kimmerii and the Keltae, wore the distinguishing close trousers, or loose pantaloons, called by them braccæ or bracchæ."

The division which that eminent historian of costume has made between the different races of the ancient world as the trousered and the untrousered is very striking, and certainly we may be permitted to entertain the opinion that the persons who fashioned the article which marked this distinction were not an unimportant section of that race. I was very much surprised to observe, when reading Mr. Thomas Hope's work, 
entitled "The Costume of the Ancients," that the lower limos of the Sarmatians and Scythians were clothed in a species of trousers descending to and being confined at the ankles with a string or band. A facsimile of these trousers may be seen at the present day on the persons of the suite of the Chinese Embassy. The trousers are cut very full in the body, and tied in at the ankle with strings. As far as I can compare, they seem to perfectly resemble the trousers worn by the ancients, as illustrated in that work.

\section{ANCIENT BRITISH COSTUMES.}

Great Britain was originally colonised by two great nomadic tribes: the Cimmerii or Cimbrians, and the Celtre or Celts. They are said to be descended from the ancient Scythians, a nation bordering on the Frozen Ocean, comprehending Russia and Tartary. They wandered from the shores of the Thracian Bosphorus to the northern coasts of Europe. Some in their migrations passed from Gaul across the Channel, others came over the German Ocean to these islands. Scarcely anything is known of the dress and manners of the early Britons before the invasion of Julius Cæsar. Brief notices of them are all that can be found in the works of ancient writers, who scarcely knew or cared to allude to this semi-barbarous people. At a very early period the Phœnician merchants traded to the Scilly islands for tin, from whence it was dug and exported. Strabo, a celebrated Greek geographer, who was born about B.c. 50, when speaking in reference to the Scilly Isles, says: "They are inhabited by a people wearing black garments or cloaks reaching down to their heels, and bound round their breasts. They walk with sticks, and wear long beards, so that when walking they looked like furies in a tragedy, although really a quiet and inoffensive people." This is a specimen of the few brief notices obtainable; and from a comparison of them it would appear that in many particulars the ancient Britons bore a striking resemblance in manners and customs to the South Sea Islanders, as described by Captain Cook.

We know, from unquestionable authorities, they followed the practice of savages in tattooing and dyeing their bodies. Pomponius Thela, who lived B.c. 45 , says: "The Britons dyed their bodies with woad (which bore a small flower of a blue colour) after they had been tattooed." Pliny describes the operation as performed in infancy by mothers and nurses of the British. Isodorus says: "They squeeze the juice of certain herbs into figures made on their bodies with the points of needles." And Herodian attributes the slight clothing of the northern tribes to their desire for displaying the figures of animals thus formed on 
their person. The object of the Britons in tattooing and dyeing themselves was to render their aspect more terrible in battle.

Julius Cæsar, who landed on these shores fifty-five years before the birth of Christ, speaking of the Britons, in his work entitled the "Gallican Wars," says : "He found the inhabitants of Kent the most civilised of all the Britons, and differing but little in their manner from the Gauls," from whom they had most probably acquired the arts of dressing, spinning, dyeing, and weaving wool, as they there practised them after the Gaulish fashion, and possessed, in common with their continental brethren, some valuable secrets in those arts unknown to other nations. These facts are confirmed by Diodorus Siculus, Strabo, and Pliny; the latter of whom enumerates several herbs used for this purpose, and tells us they dyed purple, scarlet, and several other colours from these alone; but the herb which the Britons chiefly used was the glastum or woad.

Of the several kinds of cloth manufactured in Gaul, one, according to Pliny and Diodorus Siculus, was composed of fine wool, dved with several colours, which being spun into yarn, was woven either in stripes or chequers, and of this fabric the Gauls and Britons made their lighter or summer garments. Here we have the undoubted origin of the Scotch plaid or tartan, which is called the "garb of old Gaul" to this day; and, indeed, with the exception of the plumed bonnet and the tasselled sporan or purse, a Highland chief, in his full costume, with truis, plaid, dirk, and target, affords as good an illustration of the appearance of an ancient Briton of distinction as can well be imagined. In speaking of the Belgic Gauls, Diodorus says : "They wore dyed tunics, beflowered with all manner of colours. With these they wore close trousers, which they called braccr; these trousers were an article of clothing by which all the barbaric nations seem to have been distinguished from the Romans, and were made by the Gauls and Britons of their chequered cloth." Martial has the following line of comparison :-

"Like the old braccæ of a needy Briton."

In a work "On the Costume of the Original Inhabitants of the British Islands," by Sir S. R. Meyrick and C. H. Smith, Esq., they say, "That the Cimbrian savage of Britain and Ireland, clad in the skin of the beast he had slain, issued in search of his prey from a cave hollowed by nature, or a hut scarcely artificial, which the interwoven twigs and leaves presented.in a wood." And speaking of his wife and her occupations, they say, "The partner of his life passed her time in basket making, or in sewing together with leathern prongs or vegetable fibres the skins of such animals as had fallen victims to her husband's prowess, employing for that purpose needles 
made of bone, exactly similar to those used for the heads of arrows. Clad by preference in the skin, if to be procured, of the brindled ox, pinned together with thorns (a custom still with the Welsh peasantry), ornamented with a necklace formed of jet or other beads, and with the wild flowers entwined in her long but twisted locks, she attractively became the soother of his toils." This picture of our forefathers is very interesting, as it is the first account we have of the sewing and the kind of needles used by our female ancestors. It would be too great a digression to enter into a comparison of the modes of life and simple habits and occupation of our barbaric forefathers; but the very rude implements for sewing which they used are certainly a striking illustration of the primitive manner in which they "lived, moved, and had their being."

Another very graphic description of our ancestors is also given by Herodian, when describing the incursion of the Emperor Severus, in the year 207, to repress the northern tribes, who disputed the Roman power. He says, "many parts of Britain were become fenny, by the frequent inundations of the sea. The natives swim through these fens, or run through them up to the waist in mud, for the greatest part of their bodies being naked, they regard not the dirt. They wear iron about their waists and necks, esteeming this as fine and rich an ornament as others do gold. They make upon their bodies the figures of divers animals, and use no clothing, that these may be exposed to view. They are a very bloody and warlike people, using a little shield or target and a spear; their sword hangs on their naked bodies. They know not the use of a breast-plate and helmet, and imagine these would be an impediment to them in passing the fens."

It would appear from the foregoing authorities that the ordinary dress of the primitive Briton was the skin of the brindled or spotted cow, or of the beasts killed in hunting, or a cloak of sheepskin. Before the Roman invasion the British chieftain's dress consisted of a close coat or covering for the body, shaped like a tunic, and described as chequered with various colours in divisions. It was open before, and had long close sleeves reaching to the waist. Below were loose pantaloons, called by the Irish brigis, and by the Romans brages and braccæ; whence the modern term breeches. Over their shoulders wasthrown the mantle or cloak, styled by the Romans sagum, and derived from the Celtic word saic, which signified a skin or hide, and which formed, as was previously shown, the original cloak of the country. Diodorus tells us that it was of one uniform colour generally, either blue or black, the predominating tint in the chequered trousers and tunic being red. Perhaps the clearest idea of an ancient Briton may be obtained by an 
examination of the statues of the Gaulish Chiefs in the Louvre, at Paris, who, in point of costume, exactly resembled them. A copy of one of these figures is here engraved, Fig. 1, Plate 1. He wears the capacious sagum, described by Strabo as "a garment opened in the middle, which descended nearly to his knees," and was fastened by a brooch or fibula in the centre of the breast, or sometimes upon the right shoulder. His tunic, which reaches a little below the knees, is secured by a girdle round the waist. His braccæ are very loose upon the leg, and are gathered tightly round the ankle, where they terminate in a sort of plait or fringe.

We have here the tunic mentioned, Fig. 2, Plate 1, and it is exceedingly interesting to us, as it is the oldest form of garment known to be worn by our forefathers. It is, according to Fairholt, one of the earliest, if not the most ancient shape of garment upon record. He tells us that the tunic may be seen in the sculptures and paintings of early Egypt. It was in constant use by the early Greeks, and was ultimately adopted by the Romans, and it was worn in this country in a variety of forms and lengths until the end of the fifteenth century, as may be seen by many examples. The word was also applied to the military surcoat. It is curious to remark that this term has been revived, and is applied to the military coat of the present day.

The shape of this ancient garment is sufficiently interesting to tailors to justify its illustration by a diagram. In looking at it attentively we shall see a distinct resemblance to the form of the merino under-vest worn by men of the present period. The shape of the neck, the form of the opening in front, and the cut of the body and sleeves, combine to make it a facsimile of that universally worn under-garment.

Mr. Strutt, in his elaborate work on the "Dress and Habits of the People of England," when speaking of the tunic, says, "This garment certainly is not of Saxon origin; we trace it in the monuments of highest antiquity, and so far as we can judge of it from the form, and even from the name which it bore among our ancestors, it was derived from the Romans. It was of two kinds, the short tunic worn at times by all classes of people; and the long tunic, which appeared to be the distinguishing mark of superiority of rank. The short tunic in its simplest state bears no distant resemblance to the modern shirt."

A corroboration of some of the foregoing details was furnished by the opening of a singularly interesting tumulus in 1834, on the cliffs at Gristhorpe, near Scarborough, Yorkshire. In it was found the body of a man enclosed in a coffin, roughly formed from the trunk of an oak. The skull was most striking from the unusual prominences and depressions, the nose promi- 
nent, and the whole aspect singularly wild and savage. The remains of a bronze dagger with a bone handle was found, with flint heads of arrows, and a javelin. Pins of bone and wood were found upon the body, which had been used to secure the mantle of skin in which it had been enveloped. Fragments of a bone ring and of a girdle ornament were also found, as well as a small basket of wickerwork, the bottom and sides formed of bark, stitched together by the sinews of animals. From the rude simplicity of this funeral deposit, we may safely conjecture that we look on an ancient Silurian chief who, in accordance with Roman record, devoted his days to the chase at a time when only the Phœnician traders came to the southern counties of England.

It will well repay the effort of our imaginations, if we for a moment picture to our mind's eye the physical condition of the primitive inhabitants of this country. We should see an ignorant savage covered either with the skin of animals, or the coarsest of woollen clothing; his semi-nude body decked with the forms of animals rudely drawn and gaudily coloured. His head for the most part bare, or only protected by a cap if covered at all. His feet shielded by shoes which reached to the ankles, made of raw cow hide. His house, a darksome cave, or a hut built of wattle and stakes stuck in the ground, fastened together at the top and plastered with mud; a hole in the roof served for both window and chimney; his implements of agriculture, war, and the cliase made of flint or bone. The walls of his hut bare, the floor uncovered, the scanty furniture of the simplest form and roughest material, and his food procured from the fields, the cow and the sheep, or else the product of successful hunting or fishing. His spouse was equally unsightly and equally savage. In short, their whole existence was passed amid the usual debasing conditions of uncivilised life.

If we contrast the homes and habits of these people and their surroundings, with the dwellings of the humblest of our citizens or agricultural labourers, what comforts and even luxuries in comparison do they not possess! As we move still higher in the social scale the contrast is still greater, and the progress of civilisation more evident.

As clothing is an outward indication of the physical comfort and even luxuriousness of a nation, as well as an evidence of the frivolity of taste or manners of the wearers, so a study of this subject will be more fruitful of interest and instruction than at first sight would appear. The want of food sufficient, or suitable clothing, is a clear proof of the poverty of a people, and direct evidence of their physical condition. Whilst a profusion of garments, elaborately ornamented, points irresistibly to a possession of material wealth and physical comfort. 


\section{ROMAN-BRITISH PERIOD.-A.D. 78-400.}

The first beneficial change in the social condition of the Ancient Britons was effected by their contact with the Romans, whose dominion over this country existed above a period of three hundred years. History teaches us that Julius Cæsar, the great Roman general, landed on these shores in the year 55 B.c., and entirely defeated the British forces who opposed him. The Romans continued their conquest and extended their dominion, so that after Julius Agricola was appointed to the command of Britain in the year 78, he not only succeeded in establishing the Roman dominion, but he also introduced the Roman manners and language. The effect of the contact of a higher civilisation with barbarism was soon apparent: the savage Britons became more civilised, they imitated the manners and customs, and even the dress of their conquerors, so that the Britons became quite Romanised. "The sons of the British chieftains," says Tacitus, "began to affect our dress." And this imitation proceeded so far that before the end of the first century the ancient British habit was regarded as a badge of barbarism, and was therefore discarded by the chiefs. The braccee were left off by the southern and eastern Britons, and the Roman tunic, reaching to the knee, with the cloak or mantle, varying but little from their own sagum, were the ordinary clothing of the better classes. That the young men were the first to adopt the new fashions and customs we can readily conceive, for the young are more impressionable, and readier to adopt new methods than the old, whose habits are fixed and whose prejudices are not so easily overcome.

The best information that can be gathered respecting the costume of the Romans, is contained in Mr. Thomas Hope's work on Ancient Costume. The following extract will convey to our minds the kind of dress which the Britons assumed when they abandoned their ancient garb and adopted the costume of their conquerors :-

"The pre-eminent dress of the Romans, and which distinguished them in the most marked way as well from the Greeks as from the barbarians, was the toga. This they seem to have derived from their neighbours the Etrurians; and it may be called their true national garb. In the eartiest ages of Rome it appears to have been worn by the women as well as by the men, by the lowest orders as well as by the highest, at home as well as abroad, in the country as well as in town: love of novelty probably caused it first to be relinquished by the women; next, motives of convenience by the men in lower stations; and afterwards, fondness of ease and unconstraint even by the men of higher rank when enjoying the obscurity of private life or the retire- 
ment of the country. From the unsuccessful attempts, however, first of Augustus and afterwards of Domitian, entirely to abolish a dress which still continued to remind the people more forcibly than was wished of their ancient liberty, it appears that the toga remained the costume of state on all occasions with the patricians until the last days of Rome's undivided splendour; and we may, I think, assert that not until the empire was transferred to Constantinople did the toga become entirely superseded by that more decidedly Grecian dress, the pallium.*

"The tunic was a later introduction among the Romans than the toga, and, being regarded as a species of luxury, was discarded by those who displayed and affected humility, such as candidates and others. The tunics of the men only reached half way down the thigh; longer tunics being regarded by them all as a mark of effeminacy, and left to women and to Eastern nations. The inferior functionaries at sacrifices wore the tunic without the toga; so did the soldiers when in the camp. The tunic of senators was edged with a purple border, called laticlavus, and that of the knights with a narrow border, called angusticlavus.

"The pallium, or mantle, of the Greeks, from its being less cumbersome and trailing than the toga of the Romans, by degrees superseded the latter in the country and the camp. When worn over armour, and fastened on the right shoulder with a clasp or button, this cloak assumed the name of paludamentum.

"The common people used to wear a sort of cloak made of very coarse brown wool, and provided with a hood which was called cucullus. This hooded cloak, always given to Telesphorus, the youthful companion of Esculapius, remains to this day the usual protection against cold and wet with all the seafaring inhabitants both of the islands of the Archipelago and the shores of the Mediterranean. It will at once be seen how admirably this garb would adapt itself to our more northern climate. The costume of Rome would in many instances be the most comfortable and commodious of dresses; and as it found many analogies in the British garb, the native chiefs had but to discard the bracce speedily to become Romanised. To this they soon accommodated themselves, and it became considered as a barbarism to retain the more uncivilised native dress."

In the adoption at so early a period of the manners, customs, and dress of the more civilised Romans, may be discerned certain indications of intelligence and desire for improvement. As a proof that the youth of this country possessed intelligence and

* A mantle which generally reached to the thigh, and was fastened by a fibula to the right shoulder, allowing free motion to that arm, and covering the left: its corners were loaded by weights to make it sit more straight and elegantly on the body. The Saxon cloak or mantle was precisely similar. 
aptitude for learning, may be mentioned the fact that when Julius Agricola came to Britain he praised those young Britons who studied the Latin language and literature, and declared that in genius they excelled the youths of Gaul. Even at this time we can perceive the dawn of a higher civilisation which illumined the mental horizon of the Britons, in the capacity for appreciating the comparatively advanced state of manners and customs of their Roman conquerors; and in the desire to cultivate their taste, improve their manners, adopt more enlightened customs, and add to their scanty knowledge.

\section{ANGLO-SAXON PERIOD.-A.D. 450-1016.}

The decline of the Roman Empire caused the Romans to withdraw from Britain, leaving the inhabitants unprotected and defenceless. The Britons, after enjoying more than three centuries of Roman civilisation, government, luxury, and protection, were abandoned to their own resources. Weakened by divisions within and harassed by barbarians without, their defenceless position would have ensured their destruction, had they not sought the aid of the Saxons to protect them from the incursions of the Picts and Scots. Although the Britons had advanced in civilisation, yet, like all subjected peoples, they had retrograded in warlike spirit. The Saxons, who were invited to aid in repelling, remained to conquer and subdue. Successive immigrations of Saxons and Angles followed, who afterwards acquired and divided the whole country between them. Disputes and internecine war followed, until Egbert, King of Wessex, by subduing the other states, became the first-sole-monarch of England, A.D. 827.

After a contest of a century and a half the Britons were entirely subjugated, driven into the remote recesses of the country, or else amalgamated with the Angles and Saxons. So great was the ascendancy of the conquering race that the very name of Briton disappeared. The two races were fused together, and a new race, the Anglo-Saxon, was founded. How this race took root, expanded, and flourished, until it has become one of the principal peoples of the world, is a theme for wonder and admiration.

It is in the Kentish barrows we find the most interesting relics of these early people, and of the Romano-Britons. The high grounds or downs to the south, within a distance of a few miles, in a sweep from the south-west to the south-east of the city of Canterbury, are covered by groups of barrows, which are proved to be the graves of the Kentish Saxons, from their 
arrival in this island to the beginning of the seventh century. They are most numerous over the hills towards the south-west, which may be fairly termed the ancient necropolis of East Kent.

There is no period in our national history which is more important to Englishmen than this, nor one which is more fraught with interest to our descendants. At this time was founded that great Anglo-Saxon race, which is now the most prominent, and portends to be the greatest race of people in the world. To this period must we look back for the commencement of our language, that tongue which is now spoken in all parts of the world. 'Then were planted the germs of that literature which may be equalled, but is not surpassed.

We are indebted to the early illuminators for the knowledge we possess of the costumes of this period, as they invariably pourtrayed every personage they represented in the dress of their own time. Had these artists attempted to represent the costumes of the period appertaining to their subject, or had they designed fanciful dresses, instead of faithfully copying the dresses they saw day by day, our knowledge of this subject would have been much more scant and imperfect than it is at present.

A fine example of Anglo-Saxon royal costume is to be found in a splendidly decorated Benedictional, executed for St. Ethelwold, between the years 963 and 984 , and now in the library of His Grace the Duke of Devonshire. The royal figure is represented wearing a crown of simple form, "with a plain purple tunic reaching nearly to the knees, and confined round the waist by a linen girdle. His short blue cloak, bordered with gold, covers the left arm, leaving the right one perfectly free, as it is fastened upon that shoulder by a gold fibula or brooch." The kind of bandaged stocking, so common on all Saxon figures, is seen in this instance to greater advantage than in any other known to exist. His legs are enswathed up to. the knee in garters of gold, tied in a knot at the top, from which hang tassels. In the Cotton MS. is a representation of King David playing on the harp, whose legs are crossed with bandages diagonally: this was the original "cross-gartering," as mentioned by Shakspeare in Twelfth Night; and the fashion lingered in England at a still later period. Barton Holyday, who wrote fifty years after our great dramatist, spealis of

$$
\text { "Some sharp, cross-gartered man, }
$$

Whom their loud laugh might nickname Puritan."

The general civil costume of the Anglo-Saxons, from the eighth to the tenth century, consisted of a linen shirt, ${ }^{*}$ a tunic

* Charlemagne's shirt is expressly said to have been of linen : "camisiam lineam." Eginhartus de "Vitâ Caroli Magni." 
of linen or woollen, according to the season, descending to the knee, and having long close sleeves, but which set in wrinkles, or rather rolls, from the elbow to the wrist.* It was made like the shirt, and open at the neck to put on in the same manner. It was sometimes open at the sides, and confined by a belt or girdle round the waist. Its Saxon name was roc or rooc, and it was either plain or ornamented round the collar, waists, and borders, according to the rank of the wearer.t Over this was worn a short cloak (mentil) like the Roman pallium or Gaulish sagum, fastened sometimes on the breast, sometimes on one orboth shoulders, with brooches or fibulæ.

Mr. Planché, in a critical note to Strutt, says: "Roc or frock was, in my opinion, the tunic. The surcoat or super-tunic was the over-frock." We seem to trace here, as plainly as possible, the origin of our term frock, which we apply to a shape of coat of English invention, and which, in my opinion, is unsurpassed for comfort, appearance, and style. It suits every age and every condition of man, and is equally well adapted for all ordinary occasions.

It is worth remembering that the word roc is the German word for coat, and is applied by them to all kinds of coats.

Drawers reaching half way down the thigh, and stockings meeting them, occur in most Saxon illuminations, and are altuded to by writers under the names of brech or hose.t Scin hose and leather hose are also mentioned, and may mean a species of buskin or short boot now and then met with, or Iiterally, leathern stockings.

Over these stockings they wore bands of cloth, linen, or leather, commencing at the ankle and terminating a little below the knee either in close rolls like the haybands of a modern ostler, or crossing each other sandal-wise, as they are

* In some instances these rolls are so regular as to present the appearance of bracelets, and when painted yellow they probably are intended so to do, as Malmesbury tells us the English at the time of the Conquest were in the habit of loading their arms with them ("brachia onerati"); but it is also evident that generally the marks are merely indicative of a long sleeve wrinkled up, and confined by a single bracelet at the wrist, by removing which, perhaps, the sleeve was pulled out of its folds and drawn over the hand as a substitute for gloves-a custom of which we have hereafter historical notice.

† Charlemagne's was bordered with silk: “Tunicam quæ limbo serico ambiebatur."-Eginhart. Paulus Diaconus, describing the dress of the Lombards, says, their vestments were loose and flowing, and consisted, like those of the Anglo-Saxons, chiefiy of linen, ornamented with broad borders, woven or embroidered with various colours.- "De Gestis Longobardorum," lib. iv. c. 23 .

\pm The femoralia or drawers of Charlemagne were of linen.-Eginhart. The Monk of St. Gall speaks of "tibialia vel coxalia" (stockings or drawers) of linen of one colour, bu 1ornamented with precious workmanship, lib. $i$. c. 36. By the following note, we shall perceive he meant long drawers, or hose and drawers in one, like the Gaulish braccæ. 
worn to this day by the people of the Abruzzi and the Apennines, and in some parts of Russia and Spain. They are called in Saxon scancleorg, literally shank or leg-guard, and Latinised fasciolo crurum. In the ancient canons the monks are commanded to wear them of linen, to distinguish them from the laity, who wore woollen.*

Those useful garments, brech and hose, are alluded to by Saxon writers. The breeches were tight to the leg, and sometimes ornamented round the thigh and middle of the leg with coloured bows; but sometimes they were wide at the bottom, and reached only to the calf of the leg. This style of breeches, or, as we would say, short trousers, is shown upon a mounted soldier, who is afterwards described as wearing no extra clothing of defence, and further "he has a tight dress and full trousers."

Few people are aware that the smock-frock, made of a strong flaxen fabric and reaching down to the knees, is a purely Saxon article of costume, and it is very questionable whether any style of labourer's jacket or coat which has since been worn is equally economical, durable, and suitable for the various requirements of the labouring class; the collar and wristbands of such frocks are very often curiously decorated with needlework and much in the same manner as the Saxon tunic was ornamented.

"In some illuminations a sort of half-stocking or sock, most likely the Saxon socca, is worn over the hose instead of the bandages. It is generally bordered at the top, and reminds one of the Scotch stocking, which probably, from the red crossgartering imitated upon it, is a relic of the ancient Saxon or Danish dress.

"The above articles composed the dress from all classes from the monarch to the hind. The bretwald or king, the ealderman, and the theyn were distinguished by the ornaments and richness, not the form, of their apparel; except perhaps upon state occasions, when the nobler classes wore the tunic longer and the mantle more ample: but the same articles of dress appear to have been common to Anglo-Saxons of all conditions.

"Towards the tenth century the national dress certainly became more magnificent; silk, which was known as early as the eighth century, but from its cost must have been exceedingly rare, was afterwards much worn by the higher classes. Bede mentions silken palls of incomparable workmanship, and his own remains were enclosed in silk, as were also those of Dunstan and other distinguished personages. Adhelm, Bishop of Sher-

* Du Cange, in voce Fasciola. The Monk of St. Gall says that over the stockings and drawers they (the Franks) wore long fillets, bound crosswise in such a manner as to keep them properly upon their legs. These were worn as late as the sixteenth century in France by the butchers, and called les lingettes.-_"Archæologia," vol. xxiv. p. 37. 
borne, who wrote in the seventh century, speaks of the 'admirable art' exhibited in the weaving and embroidery of the English females even at that early period, and that reputation increased to such a degree as to cause the name of Anglicum opus to be given on the Continent to all rare work of that description. A variety of colours appears to have been much admired. Red, blue, and green are most common in the illuminations. The hose are generally red or blue."

The chief, if not the only, distinction of quality at this period was made by the costliness of the materials which composed the dress, or the abundance of the ornaments with which it was enriched. The habits already described, with very few additions and little variations in their general appearance, constituted the Saxon dress for centuries. The first indication which we have of the introduction of that useful article of man's attire denominated breeches, occurs in some observations by Mr. Strutt respecting the drawers that were worn by Anglo-Saxons in the minth century. "The drawers appear," he says, "to have been made to fit the thigh with great precision, and were usually fastened some distance above the knee, and then they bear no small resemblance to the breeches of the present day."

I am also indebted to the same author for a description of the trousers of that primitive period, as he tells us that the coxalia or trousers were certainly a species of garment distinct from the drawers and stockings, for in general they appear to have been the two parts of dress comprised into one. The coxalia, from the name, must in some measure have been applicable to the hips; and from the preceding description we find that they covered the legs also, and were fastened upon them by the leg bandages. Over the trousers the leg bandages were fastened from the feet, and reached to the middle of the leg, by which means they were secured at the bottom, and answered, as I have already observed, the double purpose of drawers and stockings.

An illustration of these trousers, which was copied from an illuminated manuscript of that time, pictures to us a pair of trousers coming down to the ankles, fitting about the seat and hips, and fastened around the waist by a band. The thought occurs to me, how were those trousers cut, who cut them, and what was the physical condition of the tailors of that period? History is silent. But, looking at the semi-nude condition of the Saxon peasantry, almost barefooted, and without any covering to the head, their lot must have been indeed an unenviable one, and the artisans, although a grade higher in the social scale, must have keenly felt the pangs of poverty, if not of want.

It may be fairly presumed that we shall take an interest in all productions of that useful little implement, the needle, so that 
no apology need be giren for quoting the same author's opinion respecting the skill of the Anglo-Saxon ladies with it. "It is certain," he states, "that garments ornamented with needlework were held in the highest estimation by the Anglo-Saxons, and it is equally certain that the Saxon ladies excelled in the performance of these elegant manufactures. The Anglo-Saxon ladies employed much of their time in carding of wool, spinning, and working with the needle, and some of them also encountered the labours of the loom. The four princesses, daughters of Edward the Elder, and sisters to Athelstan, were highly celebrated for their skill in spinning, weaving, and embroidering; and Editha, the wife of Edward the Confessor, was perfectly mistress of the needle. The French and Normans, says an ancient author, admired the beautiful dresses of the English nobility, for, says he, the Englishwomen excel all others in needlework, and in embroidering with gold."

The social condition of the Anglo-Saxon people must have been wretched, for two-thirds of the nation were slaves. Beside those born in bondage, all captives in war and persons arrested for debt or crime became slaves. Their owners could whip or put them in irons. The sale and purchase of slaves were quite common, the usual price for one being four times that of an ox. From the following passage it appears that they might be yoked together as cattle: "Let every man know his team of men, of horses and of oxen." Cattle and men were the measure of value, and came under the denomination of live money, and were the medium of exchange in which the prices were estimated.

A few facts like these prove how shallow and thoughtless those people are who sigh with regret for "the good old times," and justify those who are convinced of our progress in the past, and have faith in a more glorious future.

\section{ANGLO-DANISH PERIOD, A.D. 1016-1041.}

We have very little reliable information respecting the costume of the Danes from the time of their first landing upon the British coast to the establishment of their dominion in this island by Canute the Great, but it is generally supposed that it resembled that of their Scythian kindred, the Anglo-Saxons. Arnold, of Lubeck, describes the whole nation as originally wearing the garments of sailors, as befitted men who lived by piracy and inhabited the sea; but that in process of time they became wearers of scarlet, purple and fine linen. It would appear from various passages in the Welsh chronicles, and the old Danish ballads, that the favourite if not the general colour of the Danish dress was black. Caradoc of Llancarvan, repeat- 
edly calls them the black danes, and black, bordered by red, is still common among the northern peasantry. The chronicles continually allude to them by the name of the "black army." It is probable, says Planché, that on their conversion to Christianity they cast their "nighted colour off," and on their establishment in England endeavoured to outshine the Saxons; for we are told that "the Danes were effeminately gay in their dress, combed their hair once a day, bathed once a week, and often changed their attire; by those means they pleased the eyes of the women, and frequently seduced the wives and daughters of the nobility." A manuscript register of Hyde Abbey gives illustrations of the costumes of Canute and his Queen Alfgyfe. Canute is represented in a plain tunic and mantle, the only novelty being that his mantle is tied by cords ending in conical ornaments or tassels; he wears stockings very similar to the modern Highland ones, nearly reaching to the knee, the tops ornamented by a band. In June, 1766 , some workmen who were repairing Winchester Cathedral discovered a monument, wherein was contained the body of King Canute. It was remarkably fresh, had a wreath round the head, and several other ornaments of gold and silver bands. On his finger was a ring, in which was set a large and remarkably fine stone, and in one of his hands a silver penny. 'The penny found in the hand is a singular instance of a continuance of the pagan custom of always providing the dead with money to pay Charon. It may be observed that although the monarch and many of his nobles, warriors, and domestics were Danes, the people were still Anglo-Saxons, and if any difference of dress did exist between the two nations, the Danes were as likely to have adopted the fashions of their new country as the natives were to have assumed those of their new rulers.

\section{EDWARD THE CONFESSOR AND HAROLD II.,}

\section{A.D. $1042-1066$.}

The short interval between the Danish rule and Norman conquest, during which time the crown reverted to the Saxon line, is remarkable for the change which took place in the manners and customs of the people of that period, as according to the complaint of William of Malmesbury, in the time of Edward the Confessor, "the English had transformed themselves into Frenchmen and Normans, adopting not only their strange manner of speech and behaviour, but also the ridiculous and fantastic fashions of their habits, wearing shorter tunics, clipping their hair, and shaving their beards, leaving however the upper lip still unshorn. They were also guilty of puncturing their 
skins and loading their arms with golden bracelets." A residence of twenty-seven years in Normandy, from the age of thirteen until forty, made Edward the Confessor a Norman in thought, feeling, and manners. He spoke the Norman language, and introduced their customs into his palace, which was pretty nearly populated with Norman adventurers, whose company the king, from long habit, generally preferred. The Saxons, who desired to be well with their monarch, learned to speak French, and urge their claim to notice in the favourite language of their masters, and the dress, fashions, and manners of the Normans were as faithfully imitated, much to the disgust of the genuine Saxon lords.

In the time of Edward the Confessor noblemen wore dresses of fur or skins ( $p e l l e s$, from which comes our modern word pelisse). In Michel's "Chroniques Anglo-Normandes," written about 1185 , is a curious passage, relating to a rencontre on a little bridge between London and Westminster (probably Strand bridge) between Taite, Earl of Huntingdon, son-in-law of Earl Godwin, and Siward, afterwards Earl of Huntingdon, which runs thus: "The said Earl Taite approached so near Siward on the bridge, that he dirted his pelisse (pelles) with his miry feet; for it was then customary for noblemen to use skins without cloth."

During the reign of Harold II., who had also resided at the Court of William, Duke of Normandy, the same complaint is made of the prevalence of Norman fashions. The monkish chroniclers declare that the English had transformed themselves in speech and garb, and adopted all that was ridiculous in the manners of that people. Harold is represented dressed in a plain red tunic, yellow cloak and stockings, a blue close cap, and blue shoes.

THE NORMAN PERIOD, A.D. 1066-1154.

The conquest of England by the Normans, under the command of William the Conqueror, effected a most important change in the laws, manners, customs, and costume of the inhabitants. But the change in dress was not so great as might have been anticipated, because, as it has been remarked, the English had imitated the dress and manners of the Normans, instigated by the example of Edward the Confessor, whose tastes and sympathies were entirely Norman.

It is remarkable that the best authority we have for representatives of the costumes of the Norman invaders is the celebrated Bayeux tapestry, which is traditionally reported to have been worked by Matilda the wife of the Conqueror. Archæologists have declared that this piece of work is fully 
entitled to our confidence as a faithful representation of the armour, weapons, and habits of William and his followers. This tapestry is still preserved at Bayeux, in Normandy. It is 214 feet long and 20 inches broad, and is rudely worked in coloured worsteds like a sampler. The Society of Antiquaries, impressed with the historical value of this important historical production, despatched the late Mr. C. A. Stothard to Normandy, to copy it in the most accurate manner possible. Those who are curious in this matter can see an exact representation of the Bayeux tapestry, which has been copied in full size by means of photography, and coloured in imitation of the original needlework. It will be found hung on the east wall of the Architectural Court at the South Kensington Museum. It will well repay the trouble of inspection, as it is a facsimile of a remarkable relic of the past. It is a pictorial history of the Norman Conquest, commencing with Harold's visit to Normandy at the instigation of Edward the Confessor, and pourtrays all the incidents of his stay at William's court, his subsequent departure, the death of Edward and his funeral at Westminster, the coronation of Harold, William's invasion, the battle of Hastings, and Harold's death.

In speaking of costume during the reign of William the Conqueror, Fairholt says : "The ordinary costume of the people during this reign appears to have been as simple as that of the Anglo-Saxons. Short tunics, with a sort of cape or tippet about the neck, and drawers that covered the entire leg, known as chaussès, were worn, sometimes bandaged round the leg with various colours, or crossed diagonally. Full trousers reaching to the knee are not uncommon, as may be seen in various instances, and one example occurs in the Bayeux tapestry, in which they end in a series of vandykes or points of different colour to the trouser itself. The tunic, too, was sometimes variegated in perpendicular stripes from the waist, where it was. confined by a coloured girdle. Their mantles were fastened by brooches or pins of an ornamental character, either square or round, which, having been common for ages previous, remained in fashion centuries afterwards."

The Normans and the Flemings who accompanied the Conqueror into England, and those who followed in great numbers after his establishment upon the throne, are said by our early historians to have been remarkable for their ostentation and love of finery. Personal decoration was their chief study, and new fashions were continually introduced by them. The habits of the nobility were of course more influenced by fashion than those of the common people, and the reign of Rufus is stigmatised by the writers of the period for many shameful abuses and innovations. 
The king set the example, and the clergy and laity alike became infected with the love of costly and extravagant clothing. The tunic was made larger and fuller, and the sleeves particularly so. The long tunic worn on state occasions, and the interula or linen vestment worn beneath it, actually trailed upon the ground. The length and breadth of the sleeves were sufficient to cover the whole hand. The mantles were made of the finest cloth and lined with rich furs. The extravagancy of the taste of the period is best illustrated by the grotesque shape of the shoes which were then worn. The boots and shoes were made with such extremely peaked toes that they excited the wrath of the ecclesiastical authorities, who strictly prohibited the adoption of them by the clergy. The shoes called pigaciæ had their points made like a scorpion's tail, and a courtier named Robert stuffed his out with tow, and caused them to curl round like a ram's horn; a fashion which took mightily among the nobles, and obtained for its originator the cognomen of Cornadu.

We glean some information respecting the dress of the poorer classes of the community of this period from a representation of a singular dream of Henry I., which is depicted in a manuscript of Florence of Worcester in Corpus Christi College, Oxford. It represents three husbandmen. They are each dressed in simple tunics, without girdles, with plain, close-fitting sleeves; the central figure has a mantle fastened by a plain brooch, leaving the right arm free, and one carrying a scythe wears a hat not unlike the felt hat now worn by agricultural labourers. The beards of two of these figures are ample. Ascending higher in the social scale, we find an increase in the ornamental details of dress. We can see the ordinary costume of the middle classes, as worn during the reigns of William Rufus, Henry I., and Stephen, represented on two figures, the one designed as David and the other as Noah. The first is dressed in a long tunic, reaching nearly to the ankles; it is of a red colour, and has a white lining; the collar is gilt as well as the cuffs, which reach nearly to the elbow; it is bordered with a simple ornament, and is open on the left side from the waist downward, a fashion common at this period. He has tight-fitting chaussès and high boots, or perhaps the Saxon leg bandages. The second figure, representing Noah, wears a hat similar to the Anglo-Saxon helmet in shape, a very long full red tunic, with hanging sleeves, over which is thrown a green mantle bordered with gold. His tunic also is open at the side, showing what appears to be a stocking reaching to the knee; his shoes are ornamented by diagonal lines, and complete what may be considered a sample of the ordinary costume of the age. The travelling costume of the period is shown on two figures of disciples. One wears a 
large round hat, with a wide brim, which seems to have been the original of the pilgrim's hat, and formed a distinguishing mark of their costume. His short green tunic is protected by a capacious mantle of skin, provided with a cowl or hood to draw over the head, which was frequently used in place of a hat. He wears white breeches ornamented with red cross stripes, which end at the ankle, where they are secured by a band or garter, the foot being covered by close shoes. His companion wears the common cap so frequently represented; he has an under tunic of white, and an upper one of red, and a white mantle bordered with gold; he also wears the same kind of breeches reaching to the ankle, but he has no shoes, which frequently appears to have been the case when persons went on a journey. I cannot omit mentioning one fact which is interesting to us as tailors, and which dates its origin from the time of Henry I.: the yard measure was then fixed at the length of the king's arm.

That important branch of our commerce, the woollen manufacture, was introduced about this time by some Flemings, who settled first on the Tweed, and afterwards at Haverfordwest, in Pembroke, and Worsted, in Norfolk.

The feudal system was paramount, the barons lived in their castles, which were built for strength and safety in boisterous times. Around the castle clustered the shops and houses of those who were employed by the baron. Smiths, carpenters, workers in leather, tailors, and other craftsmen, built their huts in close proximity to the castle for convenience and protection, and thus the castle often became the nucleus of a town. While the Norman nobles were richly dressed, the Saxon serf was clad in untanned hide, with sandals of boar-skin, and leathern bandage rolled half-way up the leg, and wearing round his neck a collar of brass engraved with his master's name.

It would appear, according to Strutt, that the trousers, posterior to the Conquest, ceased to form a part of a gentleman's dress, and were confined to the rustics and lower classes of the people.

The short tunic of the Normans was somewhat longer than that of the Saxons, and in the twelfth century it reached to the middle of the legs : at the same time it was also richly adorned with broad borders and collars superbly ornamented with embroideries of gold and of silver, to which were even added the embellishment of precious stones. It will be easily conceived that these remarks refer only to the garments of the nobility and personages of distinction. The tunics of the Norman rustics and slaves do not appear to have differed in the least from those of the Saxons.

The gown seems to have been very commonly worn towards the conclusion of the twelfth century: it bears great resemblance 
to the tunic, but it was much looser; and the sleeves, which were long and large, appear to have been contrived in such a manner that the arms might either be inserted in them or left at liberty. The official gown of the chief magistrate of the City of London is made much in the same manner to this day. The gowns of the succeeding centuries were made of various rich materials, and lined with furs; they then became marks of distinction, and it is abundantly evident that they were not common among the lower classes of the people.

\section{THE PLANTAGENET EPOCH, A.D. 1154-1399.}

A new source of information is afforded us by the monumental effigies of the illustrious dead, sculptured in a style of art remarkable for so dark an age, and pourtraying in minute detail the very garments as were worn by the men when living. Many of these ancient memorials are elaborately coloured and gilt, and all are of the full size of the figure. They take precedence of every other authority, until Holbein and Vandyke, whose paintings appear to place the breathing originals before us.

The earliest sepulchral effigy of an English sovereign is that of Henry II. in the Abbey of Fontevrault, Normandy. The value that is attached to these monumental figures is considerable, for, beyond doubt, they faithfully represent the deceased persons buried beneath them. "Nor can we," says the late Mr. C. A. Stothard, "otherwise account for the singular coincidence between the effigy of King John on the lid of his coffin and his body within it, when discovered a few years since, than to suppose such was the custom." A knowledge of this fact enables us to appreciate the importance of these figures in an historical point of view, and creates an intelligent interest in their examination.

The costume of the nobles during the latter half of the 12 th century imitated as nearly as possible in form and magnificence the habit of their kings. Henry II. is said to have introduced a mantle called the "Cloak of Anjou," which, being shorter than those worn in the previous reigns, obtained for him the cognomen of Court Manteau (short cloak). Of the splendour and character of the decorations of the mantles of this period we may judge from the description of one belonging to Richard I., which is said to have been nearly covered with half moons and shining orbs of solid silver, in imitation of the system of the heavenly bodies. During the reign of Henry II. the fashion of indenting the borders of the tunics and mantles seems to have been introduced, as in the last year but one of that monarch's reign a statute was passed prohibiting certain classes from wearing cut or jagged garments. 
Besides the surcoat, two other military garments are common to this period, the wambeys or gambeson, and the haqueton or acketon. The latter of these was made of buckskin filled with cotton. Both were worn as defences by those who could not afford hauberks, but they were also worn under the hauberk by persons of distinction, and sometimes in lieu of it as fancy or convenience might dictate. In the latter case these garments were stitched with silk or gold thread, and rendered extremely ornamental. The word gamboisè or gamboised, from this circumstance, was afterwards applied to saddles and other padded, stitched, or quilted articles.

The term jacket, which we now apply to various garments such as shooting jacket, Eton jacket, lounge jacket, \&c., is a word derived from an ancient military garment which was identical with the gambeson, and which is thus described:

"This part of the military habit was generally made of cloth, but sometimes also of leather doubled and stuffed with wool, tow, hair, or linen rags, and it was quilted strongly together, and fitted to the body in order to prevent it from being chafed by the external armour, as well as to defend it from the blows of the sword or spear. The gambeson descended to the middle of the thighs, and the same kind of garment was worn by the women to regulate their shape; but as Fauchel justly observes, 'it was not made so stout and strong for them, either with respect to the materials or by the quilting.' 'The facings of the military gambesons were composed of a variety of materials, but those of taffety and buckram seem to have been the most esteemed; the latter especially was considered as best calculated to resist the blows from the weapon of an enemy. In the succeeding centuries the jaque or jacket, which was only another appellation given to the gambeson, was faced with leather, that is with jacked leather, from whence the name. The oId black jack or leathern jug, and the jack boot were both so called from being made of leather hardened by the peculiar process of jacking."

Caquillart describes the jaque as made of shamois and stuffed with flocks, which he calls a jaque d'anglais or English jacket, and adds that it reached to the knees. The gambesons appertaining to persons of high rank were sometimes handsomely ornamented.

In the romance of "Gayston," mention is made of one that was quilted with gold, which must have been very expensive; we learn the price of those belonging to the common soldiers from Froissart, who tells us that John Tycle, a pourpointer (a doublet maker), of London, assisted the insurgents under Wat Tyler and Jack Straw with sixty pourpoints or gambesons, for which he demanded thirty marks or twenty pounds; it thus 
appears they were singly valued at six shillings and eightpence. When these same rioters plundered and burnt the palace of the Duke of Lancaster at the Savoy, they took his jacke, which Walsingham calls his most precious garment, and stuck it upon a spear as a mark to shoot at; but finding their arrows could not damage it sufficiently, to satisfy their hatred they chopped it to pieces with swords and hatchets.

In the reign of King John a garment called a bliaut or bliaus was worn. This appears to have been only another name for the surcoat or supertunic. It was worn by knights over their armour. In the bliaus we may trace the origin of the French blouse.

In the time of Henry II. the general male costume consisted. of the tunic, the cyclas or cointise, girded or not according to the fancy of the wearer, chaussès or stockings, and drawers. The tunic was open in front sometimes as high as the waist for greater freedom in action. Mantles and cloaks were only seen in state or travelling dresses, and for the latter purpose we hear of the supertotus or overall, an improvement on the capa, being more ample, and having large sleeves, as well as a hood.

\section{EDWARD I., A.D. 1272-1307.}

In this reign the dress of the nobles was becomingly magnificent. The long tunic and mantle, varied sometimes by the cyclas and the bliaus, composed of rich stuffs, lined with ermine and other costly furs, was the general costume of the court. A fashion appeared about this time of setting buttons closely from the wrist to the elbow. In a manuscript poem, written about the year 1300, this fashion is thus alluded to:

\section{"His robe was all of gold beganne,}

Well christlike marked, I understand,

Botones azurd (azure) everilike ane,

From his elboth to his hande."

The dress of the commonalty remains as in the last century, or as indeed from the time of the Conquest, with the addition of the bliaus or bliais (the smock frock of the present day), made generally of canvas or fustian, and worn by both sexes. Coarse woollen cloths, such as russet, berries or burreau, cordetum and sarciles, were used for the garments of the lower orders during the thirteenth century.

Jews in the time of Edward I. were obliged to have two woollen tablets of different colours, each two fingers broad and four long, sewn on the breast of their exterior garments. Cowls with points or tails to them were worn more than caps; and the blacksmith had his brown leather apron with the square bib as worn at the present day. 


\section{EDWARD II., A.D. 1307-1327.}

The twenty years' reign of Edward II. was remarkable for the increase of luxury. Each rank vied with its superior in the richness and extravagance of costume. Towards the latter end of this reign appeared the parti-coloured, straight, and shortened habits which were generally worn during the reign of Edward III. Then also appeared the long tippets or streamers at the elbows. A remarkable style of wearing the capuchon or hood was introduced at this period; instead of drawing it over the head as a monk does his cowl, it was sometimes twisted into a fanciful form, and placed upon the top of the head like a modern toque, or simply folded and balanced upon it as the women of the Pays de Bosque wear it to this day in summer. The effigy of Edward II., which may be seen upon his tomb in Gloucester Cathedral, is certainly more remarkable for the simplicity rather than the luxuriousness of the costume.

\section{EDW ARD III., A.D. 1327-1377.}

The period of this monarch's reign is very important to the student of costume, for an entire change took place both in the civil and military dress, which makes the effigies and illuminations pertaining to this epoch more remarkable than any other date from the time of the Conquest to that of Elizabeth. The long robes and tunics of the preceding reigns vanished altogether, and a close-fitting body garment called a cote hardie, buttoning all the way down the front and reaching to the middle of the thigh, became the prevailing dress of the higher classes. It was sometimes magnificently embroidered, and the splendid military belt, worn by every knight, was buckled across the hips over this new and peculiar garment. From the sleeves of this cote, which sometimes only descended to the elbow, discovering the sleeves of an under vest or doublet, buttoned from the elbow to the wrist, hung long strips called tippets, and over this dress was worn, occasionally, an exceedingly long mantle, fastened by four or five large buttons upon the right shoulder, so that when suffered to hang loose it covered the wearer entirely to the feet; but the front part being thrown back over the left shoulder, it formed a sort of cape upon the breast. A specimen of this style of dress may be seen in York Cathedral, on the effigy of William of Hatfield, second son of Edward III. His mantle, as may be perceived, is cut out at the border in the form of leaves, or else, (which is more probable, the trimming on the edge gives it that form. This fashion, which was now general, was introduced in the reign of Henry II. 
It may here be noted that the word cote, signifying a garment, is here used for the first time. It is evidently an abbreviation of the word cote hardie, and is probably the original of our present word coat, which is pronounced the same although spelt differently.

In the year 1331 two cloth weavers from Brabant settled in York. Before that time only very coarse woollen cloth was made in this country; the finer sort was imported from Flanders. It was also in this reign that Thomas Blanket, of Bristol, established looms for weaving the woollen cloths which still bear his name.

In the year 1363 we find the House of Commons solemnly debating the regulations for the dress of all classes. A complaint was made to the House of the general use of expensive clothes unsuited to the position or the income of the people, so they decreed the following amongst other resolutions : cloths of gold and silver, and habits embroidered with jewellery, lined with pure minever and other furs, were permitted only to knights and ladies whose incomes exceeded four hundred marks yearly.

Knights whose income exceeded two hundred marks, or squires possessing two hundred pounds in lands or tenements, were permitted to wear cloth of silver, with ribands, girdle, \&c., reasonably embellished with silver, and woollen cloth, of the value of six marks the whole piece; and were prohibited wearing silks and embroidered garments of any sort, or embellishing their apparel with any kinds of ornaments of gold, silk, or jewellery. Rings, buckles, pouches, girdles, and ribands, were all forbidden decorations to them, and the penalty affixed to the infringement of this statute was the forfeiture of the dress or ornament so made or worn.

The use of black as a sign of mourning seems to have been introduced at this period, as this colour appears for the first time on monuments and effigies of this period. Chaucer, in his "Knight's Tale," speaks of Palamon appearing at Arcite's funeral, " in clothes black dropped all with tears"; and Froissart tells us that the Earl of Faix, on hearing of the death of his son Gaston, sent for his barber and was close shaved, and clothed himself and all his household in black. And at the funeral of the Earl of Flanders, he says, all the nobles and attendants wore black gowns.

\section{RICHARD II., A.D. 1377-1399.}

The taste for finery was increased in the reign of this weak and luxurious monarch. "Fashions from proud Italy," and many imported by Queen Anne from Bohemia, infected even the menial servants. The vanity of the common people in their 
dress was so great, says Knighton, that it was impossible to distinguish the rich from the poor, the high from the low, the clergy from the laity, by their appearance. The curious and authentic portrait of Richard, preserved in the Jerusalem Chamber at Westminster Abbey, represents him in a robe embroidered all over with roses and the initial letter of his name; and the effigies of Richard and his queen Anne, engraved by Hollis from their monument in Westminster Abbey, present us also with splendid specimens of embroidered garments. A few sumptuary law's were enacted by Richard, but they were little attended to, and extravagance of every description seemed the object of the entire population.

Chaucer, who wrote his "Canterbury Tales" towards the close of this reign, puts a twofold lamentation into the mouth of the parson concerning "the sinful, costly array of clothing." First, as to the sin in superfluity of clothing, which maketh it so dear, to the harm of the people; and, secondly, upon the horrible disordinate scantiness of clothing as be these cut-slops or hanse-lines. Froissart mentions at this time a garment of German origin, for he tells us that Henry, Duke of Lancaster, on his return to England, entered London in a courte jaques (short jacket) of cloth of gold, "à fachon d'Almayne " (German fashion). The little jack or jaques was afterwards called jaquette by the French, and jacket by the English, as the shortened roc or tunic had been called roquette and rocket previously. The epithet "cut-slop," also applied to it, shows that it was a shortened garment. It would appear that from this the term jacket, signifying a short coat, was thus early employed-a signification which it retains to the present day.

The parti-coloured dresses which commenced about the reign of Edward II., are certainly more singular than elegant, and have a particularly grotesque appearance when- as we see John of Gaunt represented, wearing a long robe divided exactly in half -one side being blue and the other white, the colours of the House of Lancaster. Knighton says the fashions were continually changing, everyone endeavouring to outshine his neighbour in the richness of his habit and the novelty of its form. The luxurious and extravagant dress of this period was directly encouraged, if not stimulated, by the personal example of the King, as he was perhaps the greatest fop of the day. One of his coats was estimated to be of the value of 30,000 marks : its enormous cost arose from its being embroidered with precious stones. This fashion, as well as the working of mottoes and letters on the dress, and cutting the edges of mantles, \&c., into the shapes of leaves and other devices, was very prevalent during the fourteenth century.

The author of an anonymous work cited by Camden, says : 
"The commons were besotted in excess of apparel; some in wide surcoats reaching to their loins, some in a garment reaching to their heels, close before and strutting out at the sides, so that at the back they make men seem like women, and this they call by a ridiculous name gowne. Their hoods are little, tied under the chin and buttoned like the women's, but set with gold, silver, or precious stones. Their liripipes or tippets pass round the neck, and hanging down before reach to the heels, all jagged. They have another weed of silk, which they call a paltock. Their hose are of two colours, or pied with more, which they tie to their paltocks with white lachets, called herlots, without any breeches."

The tight sleeves of the preceding reigns were now out of fashion; and the Monk of Evesham speaks of the deep wide sleeves, commonly called pokys, shaped like a bagpipe, and worn indifferently by servants as well as by masters. They were denominated, he says, the devil's receptacles, for whatever could be stolen was popped into them. Some were so long and so wide that they reached to the feet, others to the knees, and were full of slits: and all that they could procure was meant to clothe their uncurable carcases with these pokys or sleeves, while the rest of their habit was short.

The social condition of the people during the reign of the Plantagenets seems to have improved. The use of tiles instead of thatch rendered their dwellings more habitable, whilst the use of glass for windows, the introduction of earthen vessels, and addition of coal fires and candles increased the comfort of their homes. Still the home comforts were few. A decent farmhouse could boast of little more than one or two beds, a few seats, a set of fire-irons, a brass pot, dish and cup.

The rate of wages at this period will give us some idea of the value of their money. Haymakers got a penny a day; labourers, three-halfpence ; carpenters, twopence ; and masons, threepence. None were allowed to work out of their own neighbourhood, except the men of Staffordshire, Derbyshire, Lincolnshire, and those from the marches of Scotland and Wales who helped to reap the English harvest.

\section{THE LANCASTER AND YORK EPOCH. HENRY IV., A.D. 1399-1411.}

The effigies of the nobility and monarchs afford the most reliable representations of the costumes of this period. A cognisance of this fact endows these relics of the past with greater interest, and enables us better to appreciate their historical importance. When perchance we visit any of our old 
cathedrals, and admire their harmonious proportions, grand design, or architectural beauty, the sculptured effigies of the worthies who flourished in this mediæval age should naturally attract a great part of our attention. With our minds thus carried back to the past, we shall no longer regard them with ignorant wonder, but pause to view them with intelligent appreciation. For example, in Worcester Cathedral we may see the earliest monumental effigy of an English sovereign (King John) in this country. In Westminster Abbey, in York, Winchester, Gloucester, and other cathedrals, we may look upon equally interesting monumental remains of bygone years. Even from our limited point of view they will be no longer uninteresting vestiges of the past, but may prove a source of sound knowledge, and a fund of pure and intelligent gratification.

The effigy of King Henry IV. in the chapel of St. Thomas a Becket at Canterbury Cathedral is one of the most splendid of our regal series. His long tunic, with pocket holes in front, is richly embroidered at the openings and the borders of the sleeves. A cape covers the shoulders, and descends in front to the girdle. The inner tunic has a roll collar, setting close up to the neck, and the mantle of state, with a broad edging of embroidery, is connected not only by cords and tassels, but by a splendidly jewelled band passing over the chest. An author says " that this is an elegant instance of a style of royal costume, uniting richness, grandeur, and simplicity."

The day before his coronation, Henry IV. made forty-six knights, and gave to each of them a long coat of a green colour, with straight sleeves furred with minever, having long hoods lined with the same kind of fur, and fashioned like those of the prelates, and on the day of the ceremony the lords wore a long tunic, called a houppelande, of scarlet, with a long mantle over it, and the knights and esquires wore the scarlet houppelande without the mantle. This houppelande was the name of a coat made of skin, formerly worn by the French shepherds and peasants.

A dandy of the fourteenth century is thus described by Camden: "He wore long-pointed shoes, fastened to his knees by gold or silver chains; hose of one colour on one leg, and of another colour on the other. Short breeches, not reaching to the middle of the thigh; a coat, one half white and the other half black or blue; a long beard, a silk band buttoned under his chin, embroidered with grotesque figures of animals, dancingmen, \&c., and sometimes ornamented with gold, silver, and precious stones."

In the fourth year of this reign the sumptuary laws were reenacted. Among other edicts it was ordained that no man, let his condition be what it might, should be permitted to wear a 
gown or garment cut or slashed into pieces, in the form of letters, rose leaves, and poesies of various kinds, or any such like devices, under the penalty of forfeiting the same, and the offending tailor was to be imprisoned during the king's pleasure.

The lower garments of gentlemen during this period were all of one piece from the foot to the waist. There were no separate stockings and pantaloons. This dress fitted as tight to their limbs as possible. Their upper garments were of various kinds and shapes. The elder gentlemen much affected a close fitting gown or coat, with skirts reaching to the feet, as is shown on the seated figure in the illustration. It was buttoned down the front, and had a row of similar buttons under each sleeve from the elbow. Their broad hats were turned up behind, and beneath them they wore a hood which enclosed both neck and shoulders like a cape. The younger men wore tunics fitting the body, belted at the waist, and with skirts terminating at the knee. The sleeves were wide, but not so long as in the preceding or succeeding reign, as our illustration shows.

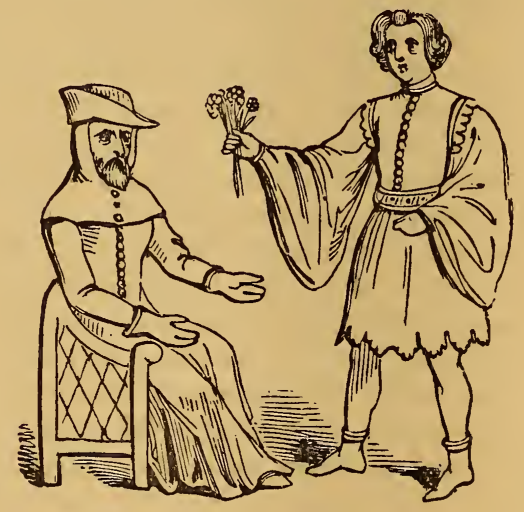

HENRY V., A.D. 1411-1422.

The civil costume of this period scarcely differs from that of the previous period. Long and short gowns, with sweeping pokys or bagpipe sleeves, fancifully indented at the edges, were generally worn by both rich and poor. Heukes of scarlet cloth and camlet and pilches of gray fur are novel articles. The first was probably a form of cloak, like that still called a heuke by the inhabitants of Morocco. The latter word is a corruption of the Latin pelliceus, or the Saxon pylce, and was an over garment of fur used in winter. Chaucer says :

"After grete hete comith colde,

No man cast his pilche away." 
The illustration gives a curious example of pendent decorations, a fashion of the period, and which continued to the time of Henry VIII. The gentleman wears a baldrick slung across

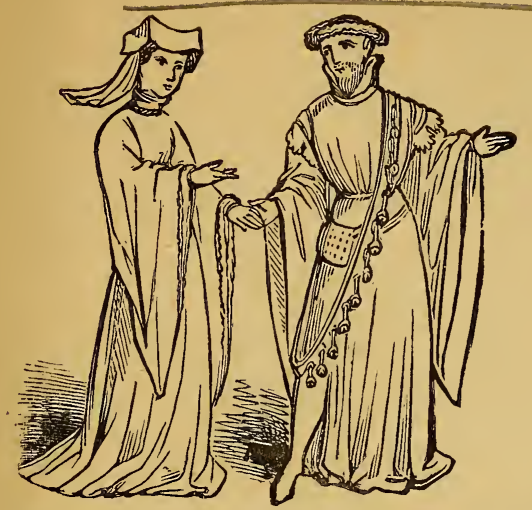

his person from his left shoulder and reaching to his right knee, which is decorated in its entire length with a series of small bells hanging by loops, so that the gentleman must, on the slightest motion, have rivalled a team of waggon horses, to whose bells those upon his baldrick bear an exact resemblance.

\section{HENRY VI., A.D. 1422-1461.}

In the middle of the fifteenth century the fashionable apparel seems to have been a jumble of the fashions of former ages, with everything the most ridiculous or extravagant that could be invented or discovered. These three figures point out dis-

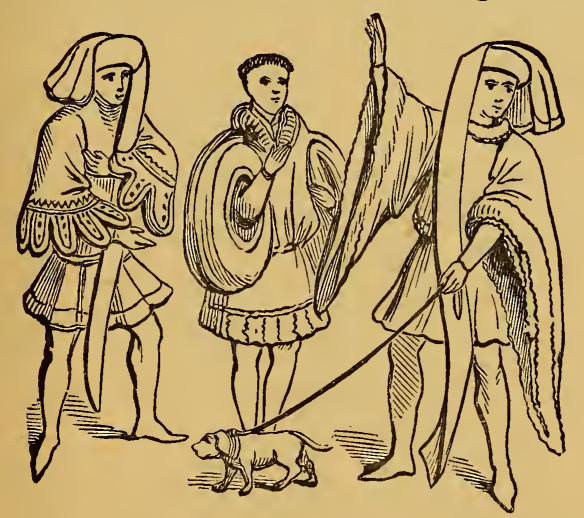

tinctly the follies of the period. These follies were, however, chiefly shown in the fantastic shapes of the caps and boots. The gown, doublet, or jacket, instead of being made close and high up in the neck, as in the last century, was now cut round, 
even with the shoulders, frequently showing the small stand-up collar, hollowed out in front, of some under vestment, with tight sleeves that protruded through openings made in the loose ones of the gown or jacket, which latter hung down, richly trimmed with fur, and seemingly more for ornament than service.

The mantle at this period was first made of velvet, and lined with white damask or satin. Legal and other official habits were composed invariably of long and full gowns, sometimes of two colours, girdled round the waist, and hoods with long tippets, by which they were occasionally slung over the shoulder. The gowns were trimmed and lined with fur, according to the rank of the wearer.

The cloak or mantle obtained an early place in the catalogue of the Jewish habits. A garment of this kind is spoken of immediately after the Deluge, as a part of dress well known, and probably derived from times still more remote than that event. This mantle covered the whole of the body; and it seems, according to a modern author, to have been much the same kind of garment as the hyke, which is still worn by the Kabyles and Arabs in Africa and the Levant. These hykes, or blankets as we should call them, are of different sizes and of different qualities and fineness; the usual size of them is six yards long and five or six feet broad, serving the Kabyle or Arab for a complete dress in the day; and as he sleeps in his raiment, as the Israelites did of old, it serves him likewise for his bed and a covering by night. The plaid of the Highlanders in Scotland is the very same. This garment appears to have been universally used by every rank of persons among the people of Israel; and was, I doubt not, the garment with four edges, which they were positively enjoined to adorn with fringes, and with ribbands of blue colours upon the fringes.

When Henry VI. returned to England after being crowned in France, A.D. 1432, the Lord Mayor of London rode to meet him at Eltham, being arrayed in crimson velvet, a great velvet hat furred, a girdle of gold about his middle, and a baldrick of gold about his neck, trailing down behind him. His three pages wore suits of red spangled with silver. The Aldermen in gowns of scarlet, with purple hoods, and all the commonalty of the City in white gowns and scarlet hoods, with divers cognisances embroidered on their sleeves. "Of older times," says Stow, "I read that the officers of this City wore gowns of particolors, as the right side of one color, and the left side of another. As, for example, I read in books of account at Guildhall, that on the 19th year of King Henry VI., there was bought for an officer's gown two yards of cloth colored mustard villars, a color now out of use, and two yards of cloth colored blew, price two shillings the yard, paid to John Pope, 
draper, for two gown cloths, eight yards, of two colors, eux ambo deux de rouge, or red medley, brune and porre (or purple) color. Price, the yard two shillings. These gowns were for Pears Rider and John Buckle, clerks of the chamber."

The Yard Measure. - The custom of the woollen drapers measuring 37 inches, or 36 inches and a thumb, is much older than we imagine; and it even seems to have been ordered by the King, as appears by the following: "The worsted and cloths called old-hames, made at Norwich as far back as the fourteenth century, were thirty yards in length; but in the third year of Edward II. a complaint was exhibited to the Parliament against the clothiers of that city for making their: cloths five yards shorter than they had been accustomed to be made, and selling them for full measure. This abuse was rectified by an Act then passed; and the price of every piece of cloth was to be regulated by the number of yards that it contained. A similar Act was made in the twenty-seventh year of Edward III., wherein it is declared that the cloth should not be forfeited, which it seems a former statute had ordained, although it might be found to be deficient of the full length, but that it should be measured by the King's aulneger, and its true contents marked upon it, and a proper allowance made to the buyer in proportion to its deficiency." The word aulneger is derived from aulne or aune, which means an ell. . It is, however to be observed that this aulne consisted of one yard and one inch, and in London it was a yard and a handful (a hand's breadth). The London measure was prohibited, anno. 18th Henry VI., and the yard, with the additional inch, commanded to be used throughout the whole kingdom.

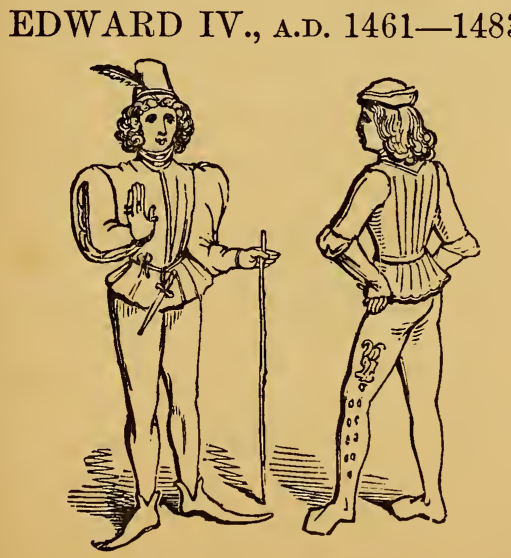

The influence of France upon English fashions was already evident, as shown on these two figures, for it is said that there 
was no fashion, however ridiculous, which was started in France, but that it was immediately adopted in England. The "Chronicles of Monstrelet" state, "that the jacket, doublets or pourpoints, were cut shorter than ever, and the sleeves slit, so as to show their large, loose, and white shirts." The padded shoulders of the present day are, it seems, no novelty, for the writer continues: "The shoulders were padded out with large waddings called mahortres, and so capricious were the beaux of the period, that he who to-day was shortly clothed, was habited to-morrow down to the ground. Even boys wore doublets of silk, satin, and velvet."

With the view of checking some of these extravagances, an Act was passed in the third year of this reign. Amongst other prohibitions were the following: "No one under the estate of a lord was permitted to wear the indecently short jackets, gowns, \&c.; or pike, or poulains to his shoes and boots exceeding two inches in length. No yeoman, or person under the degree of a yeoman, was allowed bolsters or stuffing of wool, cotton or cadis in his pourpoint or doublet, under a penalty of $6 \mathrm{~s} .8 \mathrm{~d}$., fine and forfeiture awarded. And to every tailor making such short or stuffed dresses, or shoemaker or cobbler manufacturing such long-toed shoes for unprivileged persons," Stow adds, "the pain of cursing by the clergy for the latter offence, as well as the forfeit of $20 \mathrm{~s}$. - one noble to the King, another to the Cordwainers of London, and a third to the Chamber of London."

\section{EDWARD V. \& RICHARD III., A.D. 1483-1485.}

Contrary to all our preconceived notions, Richard III., "the crooked-back tyrant," appears to have been always magnificently attired. His dresses were rich and costly, more suitable to the courtier than the warrior.

The dress of the nobility of this period consisted of hose or long stockings, which we are already conversant with as the Norman chaussès. They were tied by points, as the laces were called, to the doublet, which was sometimes open in front about halfway down the breast, showing a placard or stomacher, over which it was laced like a peasant's bodice. Over the doublet was worn either a long or a short gown-the former hanging loose, the latter full of plaits before and behind, but plain at the sides, and girdled tightly about the waist. These upper vestments had sleeves of various descriptions, very full, and slashed in front, so as to let the arm through; or cut open at the elbow behind, and showing the sleeve of the doublet, or even of the shirt, the doublet being slashed also, and laced across for ornament sake merely. 


\section{THE TUDOR PERIOD, A.D. 1485-1603. HENRY VII., 1485-1509.}

We are now entering upon a most interesting period. The Wars of the Roses had terminated, after desolating the land. The contending Houses of York and Lancaster were united in the persons of Henry VII. and his Queen Elizabeth of York; and the nation was looking forward hoping for a term of tranquillity and prosperity. The introduction of printing into England had created some desire for knowledge, and men began to read and think for themselves. So important is this era that an English historian has stated "that true English history begins with the reign of Henry VII."

We have now passed the periods of doubt, uncertainty and supposition, and are approaching a time when the illustrations of costume are more numerous and more reliable than previously, for the celebrated portraits painted by those eminent artists, Holbein, Rubens, and Vandyke, afford us clear examples of the costumes of the period.

"At the close of the fifteenth century," says Strutt, "the dress of the English was exceedingly fantastical and absurd, inasmuch that it was even difficult to distinguish one sex from another." This is quite evident, for on looking at the right hand figure one fails to distinguish that difference of attire

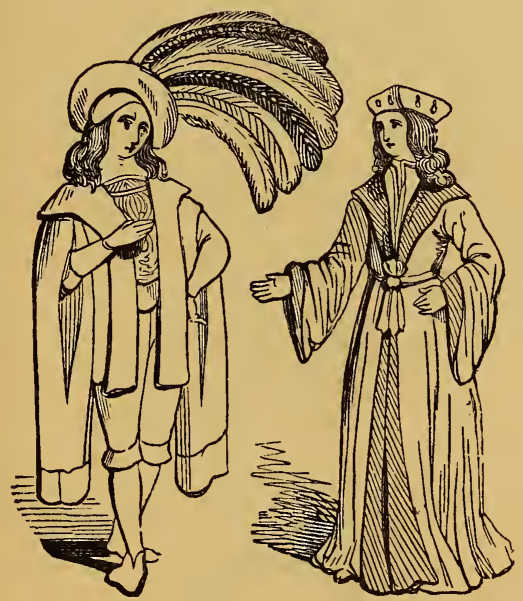

which should, and usually does, distinguish the sexes. The names which were given to various articles of men's clothing at this time would seem to sustain this remark, for in a MS. of this date, called the "Boke of Curtasye," the chamberlain is commanded to provide against his master's uprising, "a clene sherte and breeche, a pettycote, a doublette, a long cotte, a 
stomasher, hys hozen, hys socks, and hys schoen." The term pettycote used here is certainly a corruption of the French petit, little, and cote, a coat, meaning a little coat. Another author gives the following directions: "warm your soverayne his petticote, his doublette, and his stomacher, and then put on his hozen, and then his shoen, or slippers, then stryten up his hozen mannerly, and tye them up; then lace his doublette hole by hole," \&c.

The elegant fashion of slashing makes its appearance about this time, and the opening of the sleeve at the elbow, first observable in the costumes of the reign of Edward IV., has introduced another curious fancy, the complete division of the sleeve into two or more pieces, and their attachment to each other by means of points or laces, through which the shirt is seen puffed and protruding.

REIGN OF HENRY VIII., A.D. 1509-1547.

This Illustration is copied from Holbein's portrait of the Earl of Surrey, exhibited in the picture galleries of Hampton Court Palace; and I have no doubt it has been seen and

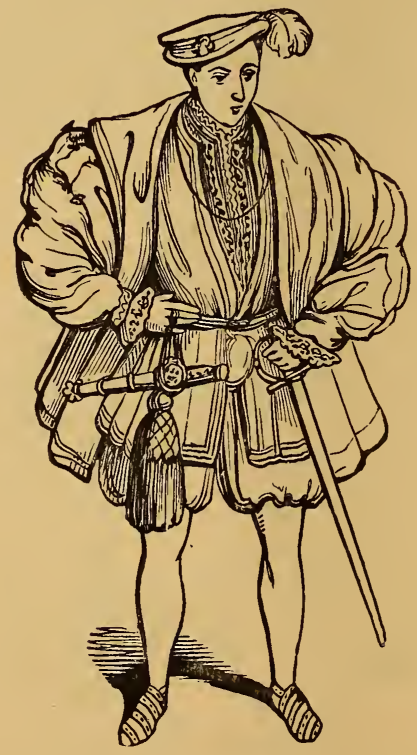

admired there by many of my readers. Fairholt describes it as "a fine example of the usual costume of the nobility and gentry of the period." The dress is of a scarlet color ; the doublet is short and open in front, displaying his white shirt embroidered with black. His ruffles are similarly embroidered; his jerkin 
is broad in the shoulders and wide in the sleeves, which are gathered in and pressed and slashed. He wears full trunk hose and tight stockings, and a small flat cap with a feather at the side.

The portrait of King Henry VIII. is perhaps the most familiar to us of all our monarchs. The events of his reign are so important, and his personal. qualities, virtues as well as vices, had such a powerful influence in guiding the destinies of this country, that we shall probably regard with increased interest the costume of his time.

The ordinary costume of King Henry, as well as that of the nobility and gentry, consisted of a full-skirted jacket or doublet, with large sleeves extending to the wrist, over which was worn a short but equally full coat or cloak, with loose hanging sleeves, and a broad rolling collar of fur. Soon after his accession were introduced the close hose fitting exactly to the limbs, which we are already familiar with as the chaussès worn in the time of the Norman kings, but now called trouses. This word trouses would seem to be the parent of our modern word trousers. The French word for trousers is pantalon, and the German words are hosen and beinkleider, therefore it is evident that our term is not derived from either of these sources, but owes its origin to the very similar term of trouses.

Camden, in his "Remains," tells an amusing tale of a shoemaker at Norwich, named John Drakes, who in the time of Henry VIII., coming to a tailor's and finding some fine French tawny cloth lying there, which had been sent to be made into a gown for Sir Philip Calthrop, took a fancy to the colour, and ordered the tailor to buy as much of the same stuff for him and make him a gown of it, precisely of the same fashion as the knight's, whatever that might be. Sir Philip arriving some time after to be measured saw the additional cloth and enquired to whom it belonged. "To John Drakes," replied the tailor, "who will have it made in the self-same fashion as yours is made." "Well," said the knight, "in good time be it, I will have mine as full of cuts as thy shears can make," and both garments were finished according to the order. The shoemaker on receiving his gown slashed almost to shreds, began to abuse the tailor, but received for answer, "I have done nothing but what you bade me," for as Sir Philip Calthrop's gown so have I made yours." "By my satchel," growled the shoemaker, "I will never wear a gentleman's fashion again."

In this reign persons dressed very much as the yeomen of the guard, commonly known as "Beefeaters," are now attired, in very showy clothes full of red and yellow stripes. The courtiers stuffed out their clothes, to make themselves look as big as the king. But though all their dress was wide and baggy, yet the 
sleeves were so tight that some had them sewed on their arms every day.

It is somewhat difficult to say whether the word hose used at this period meant either breeches or stockings, but there is some ground for believing it meant the former, as in an inventory of the king's apparel, preserved in the Harleian library, mention is made of several pairs of silk hose, and among them, one of purple silk and Venice gold, and with blue silver sarsnet edged with passernain (lace) of purple silk and gold wrought at Milan. These lined hose would clearly refer to breeches, and this seems confirmed by what follows, in which we trace the origin of the word stockings. One entry runs thus: "A yarde and a quarter of green velvet for stocks to a payr of hose for the king's grace," and numerous other entries occur of lengths of stuff used for "stockyng of hose." These splendidly embroidered hose were fastened by points or laces with tags called anglettes or aglets to the doublet, which was of equal magnificence. We read of a " doblet of white tylesent cut upon cloth of gold, embroidered with hose to the same and claspes, and anglettes of gold delivered to the Duke of Buckingham. Over the doublet was worn the jacket, now sometimes called the jerkin, the coat, or the gown, according to fancy or circumstances."

When Henry VIII. met Anne of Cleves he was habited, according to Hall, "in a coat of velvet, somewhat made like a frocke, embroidered all over with flatted gold of damaske." . The "frocke" alluded to by Hall, is a garment frequently mentioned about this time. Hall says it was a sort of coat, jacket or jerkin, made like them, occasionally with bases or skirts. Strutt considers that it had no sleeves. We have here certainly the origin of our term frock-coat. Various styles of gowns were worn, such as long, short, half, straight, and loose, Turkish and Spanish, with sleeves, collars, capes and aglets, and diamond and gold buttons set upon the sleeves. Two garments called the chammer and shamen, described by Hall as "gownes cut in the middle," as well as another called the glaudkyn, are spoken of in the earlier inventions of this reign. One remarkable fashion existed at this time, which is worthy of our notice: both the sleeves and the capes of the various garments were made so as to be put on or taken off the dress by means of points or buttons.

Waistcoats seem to have been invented at this time; they were worn under the doublet, and had sleeves, and were made of rich materials. Ladies also wore waistcoats similar to those worn by the gentlemen. "Two waistcoats for women, being of clothe of silver embroidered, both of them having sleeves," is an entry in the inventory of ladies' apparel.

We may gather some information respecting the dress of the 
citizens and merchants, \&c., of this period, from the various prints of the time. In the History of John Winchcomb, the famous clothier called Jack of Newbury is described as going to Henry VIII. dressed in a plain russet coat, a pair of white kersie slopps or breeches without welt or guard (i.e. lace or border), and stockings of the same piece, sewed to his slopps. Articles of dress were so valuable that they were frequently left in wills, as William Cheryngton, yeoman of Water-beche, 14th August, 1540, leaves "to my mother, my holyday gowne;" and John Holden, rector of Gamlingay, 29th October, 1544, leaves to Jone Grene "my clothe frock, lined with sattin of Cypress." As early as this reign all the apprentices of London wore blue cloaks in summer, and in the winter gowns of the same colour. Their breeches and stockings were usually made of white broadcloth, "that is round slopps or breeches, and their stockings sewn up close thereto, as they were all but of one piece."

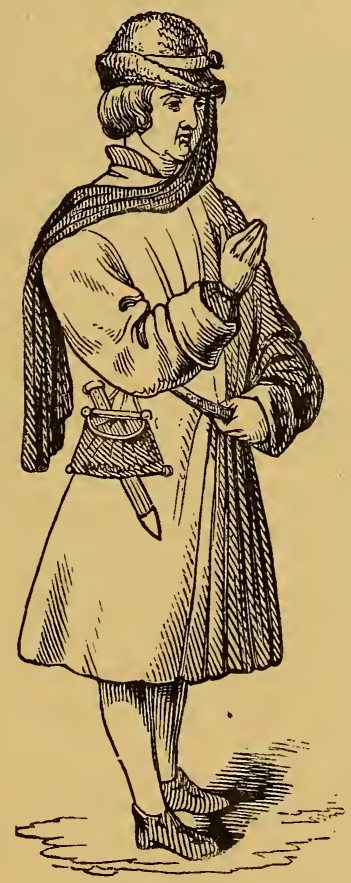

This figure is dressed remarkably simple, and may be described as of the type of a plain gentleman of this period. He wears a close hat with a band and buckle, and it affords an excellent example of the long pendant streamer of cloth affixed to it, while his dagger and purse, those invariable appendages to a gentleman, are hung at his girdle. 
These two figures are specimens of the ordinary costume of the people during this reign. The male figure is dressed in a plain doublet, hose puffed to the knees, tight fitting stockings, a

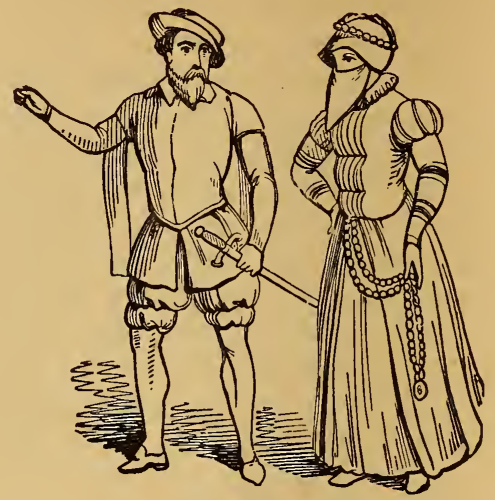

small close cap and narrow collar round the neck. The female wears a close hood and her face is partially covered by a muffler.

The following satirical remarks upon the fashions were written by Thomas Becon in "The Nosegay," published 1540-50:

"What shall I say of the manifold and strange fashions of the garments that are used nowadays? I think Satan studieth not so much to invent new fashions to bring Christian men into his snare, as the tailors nowadays are compelled to excogitate, invent, and imagine diversities of fashion for apparel, that they may satisfy the foolish desire of certain light brains and wild oats, which are altogether given to new fangleness. $\mathrm{O}$, most vain vanity! Sometimes we follow the fashion of Frenchmen; another time we have a trick of the Spaniards. Shortly after that beginneth to wax nought, we must therefore now have the Italian fashion. Within a few days after, we are weary of all the fashions that are used in Christendom; we will therefore now, and God will, practise the manner of going among the Turks and Saracens; would God that with the Turks' apparel we were also not right Turks and infidels in our life, conversation, and manners."

Bishop Pilkington, writing in 1560 , says :-

"But these tender pernels must have one gown for the day, another for the night, one long, another short, one for winter, another for summer, one furred through, another but faced; one for the work, another for the holiday, one of this colour, another of that, one of cloth, another of silk or damask; change of apparel, one afore dinner, another after; one of Spanish fashion, another Turkey; and, to be brief, never content with enough, but always devising new fashions and strange. Yea, a ruffian will have more in a ruff and his hose than he should 
spend in a year. I read of a painter that would paint every countryman in his accustomed apparel, the Dutch, the Spaniard, the Italian, the Frenchman ; but when he came to the Englishman, he painted him naked, and gave him clothe and bade him make it himself, for he changed his fashion so often, that he knew not how to make. it, such be our fickle and unstable heads ever devising and desiring new toys."

The reference which is made to the changeful taste of the Englishman appears in a book entitled "The Fyrst Book of the Introduction of Knowledge," by Andrew Boorde, published in 1542. Under a rude sketch of a naked Englishman, with a pair of shears in his hands, is written these lines :-

"I am an Englishman, and naked here I stand, Musyng in my mynde what rayment I shall wear; For now I wyl were thys, and now I wyl were that, Now I wyl were I cannot tel what."

One of our old authors, Stubbs, in his "Anatomie of Abuses in England," published in 1584, has several satirical and severe observations respecting the costume of that period. He says :

"Their dublettes are noe less monstrous than the reste, for now the fashion is to hang them downe to the middest (middle, of their thighs, beeing so hard quilted and stuffed, bombasted (wadded) and sewed, as they can verie hardly either stoupe downe, or decline them selves to the ground, soe styffe and sturdy they stand about them certaine I am there was never any kinde of apparell ever invented that could more disproportion the body of man than these dublets with great bellies, hanging down beneath their pudenda, and stuffed with foure, five, or six pound of bombast at the least. I say nothing of what their dublets be made, some of saten, taffatie, silk, grogram, chamlet, gold, silver, and what not; slashed, jagged, carved, pincked and laced with all kinde of costly lace of divers and sundry colors, for if I should stand upon particularities, rather time than matter would be wanting.

"Then have they hosen, which as they be of divers fashions, so are they of sundry names. Some be called French hose, some gally hose, and some Venetians. The French hose are of two divers makings, for the common French hose (as they list to call them) contayneth length, breadth and sideness sufficient, and is made very round. The other containeth neither length, breadth nor sideness (being not a quarter of a yard side) wherof some be pared, cut and drawne out with costly ornaments, with Canions annexed, reaching down beneath their knees.

"The gally hosen are made very large and wide, reaching dov ne to their knees onely, with three or four guardes a peece laic down along either hose. And the Venetian hosen they reach 
beneath the knee to the gartering place to the leg, where they are tyed finely with silk points, or some such like, and laid on also with rewes of lace or gardes as the other before. And yet nothwithstanding, all this is not sufficient except they be made of silk, velvet, saten, damask, and other such precious things beside.

"Their coats and jerkins as they be diverse in colors, so be they diverse in fashions, for some be made with colors, some without, some close to the bodie, some loose, covering the whole body downe to the thighe, like bagges or sacks that were drawen over them, hiding the dimensions and proportions of the body; some are buttoned downe the brest, some under the arme, and some downe the back, some with flappes over the brest, some without, some with great sleeves, some with small, and some with non at all; some pleated and crested behind and curiouslye gathered, and some not so.

"They have clokes there also in nothing discrepante from the rest, of dyverse and sundry colors, white, red, tawnie, black, greene, yellowe, russet, purple, violet, and infinite other colors; some of cloth, silk, velvet, taffetie, and such like, wherof some be of the Spanish, French, and Dutch fashion; some short, scarcely reaching to the gyrdle head or wast, some to the knee, and otherwise trailing upon the ground (almost) liker gownes than clokes. These clokes must be garded, laced and thorowly faced, and sometimes so lyned as the inner side standeth almost in as much as the outside; some have sleeves, other some have none, some are hanged with points and tassels of gold, silver, or silk, some without al this; some have hoods to pull over the head, some have none. But how soever it might be the day hath bene when one might have bought him two clokes for lesse, than now he can have one of these clokes made for, they have such store of workmanship bestowed upon them."

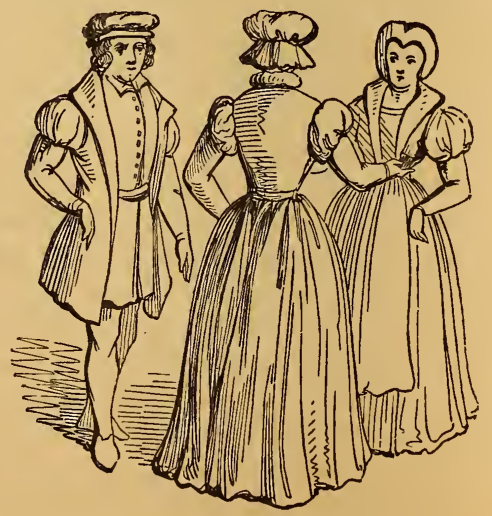

The male figure in this engraving is dressed in a plain jerkin, 
doublet, and hose, and wears a flat cloth cap on his head, of the fashion usual with citizens, and which was ultimately known as "the city flat cap." This cap was obliged to be worn in Elizabeth's time, according to law, by working people and tradesmen on Sundays or holy days, or else they were subject to a fine of $3 \mathrm{~s} .4 \mathrm{~d}$. for each transgression.

\section{EDWARD VI., A.D. 1547-1553, AND MARY,}

$$
\text { A.D. } 1553-1558 \text {. }
$$

The ordinary costume of men in the middle ranks may be seen in this full length portrait of John Heywood. It was the dress of the citizens and merchantmen of London. The flat cap

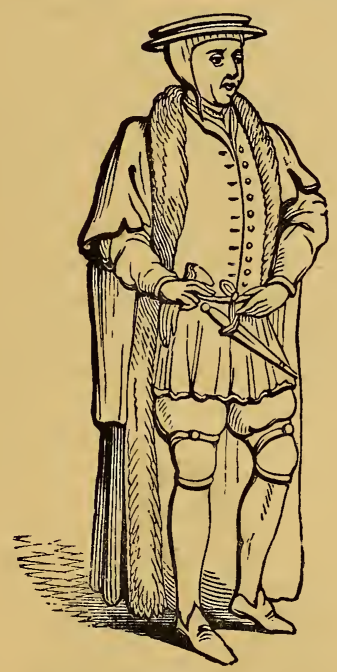

surmounts the head, a coif made to tie beneath the chin completely envelopes the hair, and he wears a long furred gown with hanging sleeves.

But little change is observable in the costume of these reigns, yet we have a perfect specimen of the dress of that time, worn by the boys of Christ's Hospital, commonly called Blue Coat Boys. It will be remembered that Edward VI. founded Christ's Hospital. The flat cap, which will not rest on the head, the single-breasted coat or gown, with plaited skirts, drawn in at the waist by a belt, the knee-breeches, and the yellow stockings are familiar to us all. Blue was considered to denote servitude, therefore blue coats were worn by apprentices and serving men. From this reign also dates the coats worn by firemen and watermen up to a recent period. Minstrels, players, and all retainers of the nobility were dressed in a similar manner. 
ELIZABETH, A.D. 1558-1603.

The costume of the Elizabethan era is replete with interest, as it shows us the outward garb of our forefathers in the 16th century, when the religious animosities of the previous reigns had subsided, when our navy was founded, our commerce extended, our influence established, scientific knowledge expanded, modern English adopted, and our literature enriched with its noblest adornments.

A change had been gradually taking place in the form of dress during the reigns of Henry VIII., Edward VI., and Mary, until what is generally known as the "Elizabethan costume," was adopted. It was composed of a short cloak or mantle, with a standing collar, a long-waisted doublet, and large trunk hose, a ruff round the neck, and a hat with a band and feather. The bases or skirts of the coats and jackets descended nearly to the knee. The very large breeches or sloppes were bombasted out and became a conspicuous feature in a man's apparel. The long hose were either supplanted by or rechristened the trouses, the upper stock or breeches worn over them were named trunk-hose, and were stuffed, paned, and ornamented in the most extravagant manner, whilst the nether stock, worn upon the lower part of the leg, received its modern name of stocking.

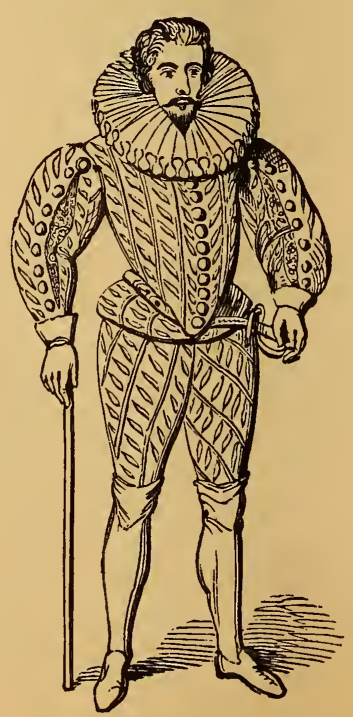

This full length portrait of Sir William Russell, one of Eliza- 
beth's courtiers, is an excellent specimen of the dress of a nobleman of the period. He wears an immense ruff, a richly ornamented peascod-bellied doublet, quilted or stuffed, and apparently constructed of rich black silk, the point of the waist hanging over the sword-belt. It is covered with slashes, and one large one at the arms shows the rich lining of figured lace beneath. The opening at the sleeves has a large row of ornamented buttons on one side and loops on the other. He wears the Venetian hose slashed like the doublet, his stockings are of the finest yarn, and his shoes of white leather.

Strutt has a very curious note from a manuscript in the Harleian Library, which shows the enormous extent of the trunk-hose. Memorandum: "That over the seats in the Parliament House there were certain poles, some two inches square, in the walls, in which were placed poles to uphold a scaffold round about the house within, for them to sit upon who used the wearing of great breeches, stuffed with hair, like wool sacks, which "fashion being left the eighth year of Elizabeth, the scaffolds were taken down and never since put up."

Bulwer, in his "Artificial Changeling," 1653, gives the following description of trunk-hose: "At the time when the fashion came up of wearing trunk-hose, some young men used to stuff them with rags and other like things, that you might find some that used such inventions to extend them in compasse with as great eagerness as the women did take to weare great and stately verdingales, for this was the same affectation, being a kind of verdingale breeches." He then relates how a gallant, in whose immense hose a small hole was torn by a nail of the chair he sat upon, so that as he turned and bowed to pay his court to the ladies, the bran poured forth as from a mill that was grinding, without his perceiving it, till half the cargo was unladen on the floor.

The doublets were as various in form as the hose. At first, they fitted the body, and the waist was gradually lengthened. They wore what afterwards obtained the name of the long peascod-bellied doublet, quilted and stuffed with four, five, or six pounds of bombast, the exterior being of satin, silk, taffeta, grogran, camlet, gold or silver stuff, slashed, jagged, cut, carved, pinched and laced with all kinds of costly lace, of divers and sundry colours. These bombasted doublets formed a point in front, hanging over the girdle, and, allowing for a little caricature, is to this day the body dress of our old and inestimable friend "Punch," whose wardrobe of Italian origin dates as nearly as possible from this identical period. Over these were worn coats and jerkins, some with collars, some without, some close to the body, some loose, which they called mandillians, covering the whole of the body, like sacks or bags, 
some buttoned down the breast, some under the arm, and some down the back, some with flaps over the breast, some without, some with great sleeves, some with small, and some plaited and crested (striped) behind, and curiously gathered, some not: one man having as many sorts of apparel as there are days in the year. They had cloaks also of white, red, tawny, black, green, yellow, russet, violet, \&c., made of cloth, silk, velvet and taffeta, and after the Spanish, French, and Dutch fashions: some short, scarcely reaching to the girdlestand or waist, some to the knee, and others trailing on the ground, resembling gowns rather than cloaks, and guarded with velvet guards, or else faced with costly lace of gold, silver, or silk, three or four fringes (fengers?) broad, down the back, about the skirts, and everywhere else. A new fashion at this time was to guard the cloaks, round about the skirts, with bugles and other kinds of glass, "and all to shine to the eye." Besides, these cloaks were so faced and lined that the inner side costs as much as the outer. Some had sleeves, and some hoods to pull up over the head; some were "hanged with points and tassels of gold, silver, and silk."

Tailors must have had alterations to make in those times for their fastidious clients, since that esteemed chronicler, Holmshed, says, "How curious, how nice also, are a number of men and women, and how hardly can the tailor please them in making it fit for their bodies. How many times must it be sent back again to him that made it? then must we put it on, then must the long seams of our hose be set by a plumb line." This alteration shows clearly that the hose were required to fall straight, and the seams not to deviate from the perpendicular.

In Ben Johnson's play entitled, "Staple of Newes," the following remark is made respecting dress : "In Act I, scene I, Peniboy junior walks in his gowne, waistcoate, and trouses, expecting his tailor."

A curious occupation for tailors is recorded by Mrs. Stowe in her "Chronicles of Fashion." It is there stated, "That on Queen Elizabeth's visit to Norwich in 1570, eight children knitting yarn hose were introduced in one of the pageants. Before this period stockings were made of silk, velvet, or damask, by tailors." - This curious statement is explained by the following remarks: "For male attire the breeches and stockings were at first made in one piece; but the lower part required sometimes to be renewed, which operation was called 'stocking the hose." When they were habitually divided into two parts, they were called the upper and nether stocks; and the lower part was eventually named stockings. As in France, the upper part being called "haut de chaussès," and the lower part the "bas," the present French word for stocking. 


\section{THE STUART PERIOD, A.D. $1603-1736$.}

JAMES I., A.D. 1603--1625.

The costume of the previous reign was worn during this, only the large Gallic or Venetian hosen were, however, still increased in size, and slashed, quilted, stuffed, and guarded (laced) as formerly. The long-waisted or peascod-bellied doublet also remained in fashion. James was a very timorous monarch, so for his personal protection he had his clothing made very large, his doublets quilted for fear of stilettoes, and his breeches plaited and stuffed very full. The enormous expanse of the trunk hosen was quite a disfigurement to the person. There seems to have been no idea of proportion, nor thought of the form of a man. To add to the absurdity of this style a ruff was worn around the neck, and the head surmounted by a sharp pointed crowned hat adorned with a figure, so as the breeches terminated at the garter, the figure tapered gradually from the middle to both ends. A folly still more absurd and reprehensible was practised by the dandies of the period, namely, that of wearing stays, and lacing them tightly, for we read that "Stays were sometimes worn beneath the long-waisted doublets of the gentlemen to keep them straight and confine the waist."

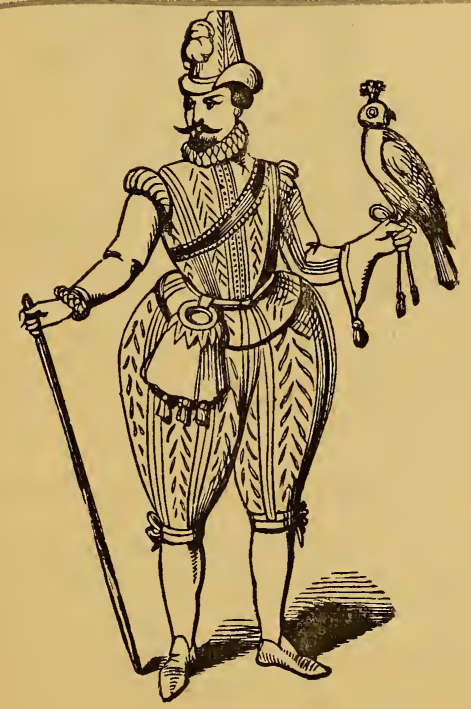

This Portrait of James I. hawking, gives a clear specimen of the costume of the period worn by the nobility. The great full breeches are now tapered to the knee and slashed all over and covered with lace and embroidery. 
Some slight change took place towards the close of this reign. Short jackets and doublets with tabs, and false sleeves hanging behind, succeeded to the long-waisted doublets, and the hose instead of being slashed or laced, were covered with loose broad straps richly embroidered, or adorned with buttons, discovering the silk or velvet trunk at the narrow intervals between them. The loose Gallic hosen were still worn and fastened to the doublet or jacket just above the tabs by innumerable points.

The extravagance which some noblemen displayed in their dress is almost incredible: a notable example is that of the celebrated Duke of Buckingham, favourite of James I., who before going over to Paris in 1625, had twenty-seven suits of clothes made, the richest that embroidery, lace, silk, velvet, gold, and gems, could contribute; one of which was a white uncut relvet, set all over, both suit and cloak, with diamonds, as were also his sword, girdle, hatband, and spurs.

The two figures represented by the following engraving are members of the Leather-sellers' Company in the time of

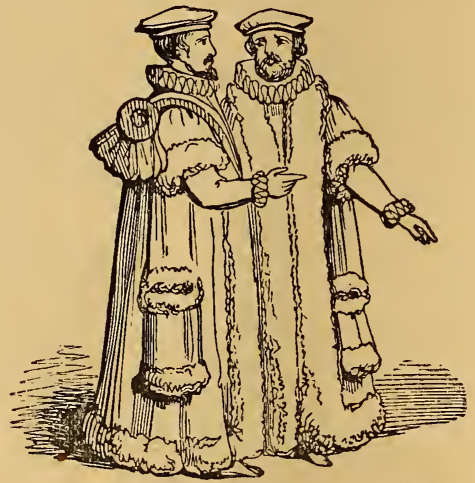

James I. They wear "the city flat-cap," small ruffs and long gowns trimmed with fur, hanging sleeves.

\section{CHARLES I., A.D. 1625-1649.}

During the earlier part of Charles's reign the fashions of the previous one prevailed, but about 1637 the costume known as King Charles's was introduced. There is no costume more generally known and admired than that of this period, for we see it continually presented on the stage, and it is a favourite dress with those who love display at fancy and masked balls. The celebrated portrait painter of this period has by his eminent talent perpetuated this elegant and picturesque dress. Although it is the most suitable for stage effect, it would be found the 
least adapted for the uses of our daily life. It was appropriate to the gay, licentious, and dissipated manners of the period, but the utter incongruity of velvet, lace, and feathers with man's everyday employment is too evident to admit of comment. Picturesqueness of effect, and not utility, was its end ; but this it succeeded in obtaining.

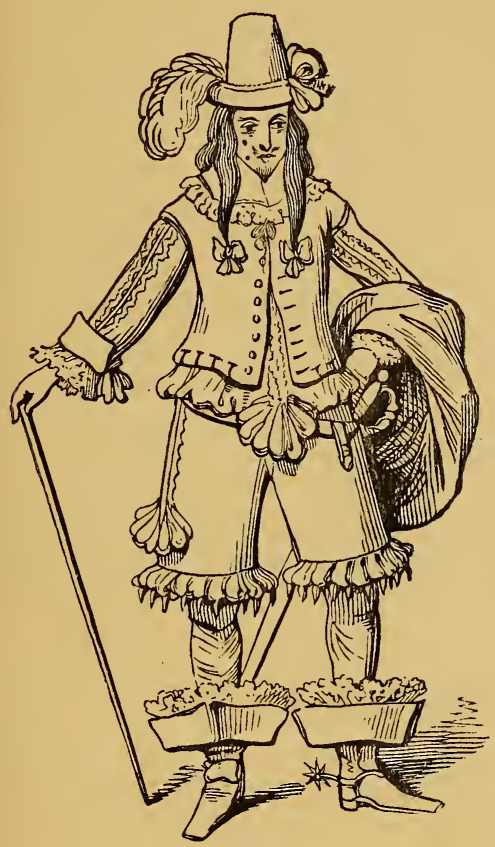

This is a curious representation of a dandy of the period. He wears a tall hat with a bunch of ribbon on one side and a feather on the other; his face spotted with patches; two lovelocks, one on each side of his head, which hang upon his bosom and are tied at the ends with silk ribbon in bows; a tight vest partly open and short in the skirts, between which and his breeches his shirt protruded; his breeches were ornamented by many dozens of points at the knees, and above them on either side were two great bunches of ribbon of several colours.

The costume of a cavalier, as those belonging to the royalist party were named, shows us clearly the dress of the period. It consisted of a doublet of silk, satin, or velvet, with large loose sleeves, slashed up the front; the collar, covered by a falling band, i.e., a collar of the richest point lace, with that peculiar edging now called Vandyke; a short cloak was worn carelessly on one shoulder. The long breeches, fringed or pointed, 
already mentioned, met the tops of the wide boots, which were also ruffled with lace or lawn. A broad-leaved Flemish beaver hat, with a rich hatband and plume of feathers, was set on one side of the head, and a Spanish rapier hung from a most magnificent baldrick or sword-belt, worn sashwise over the right shoulder. The doublet of silk or velvet was frequently exchanged in the troublous times for a buff coat, which was richly laced, and sometimes embroidered with gold or silver, and encircled by a broad silk or satin scarf, tied in a large bow, either behind or over the hip, in which case the short cloak was perhaps dispensed with. In some instances a buff jerkin without sleeves was worn over the doublet.

The following is a description of the average type of the ordinary dress of persons in middle class society: The hair was worn long and flowing, resting upon a plain "falling band," as the collar was termed when of this fashion, a doublet of a form like that still worn by Thames waterman in City pageants, gathered at the waist, with wide sleeves, and plain white linen cuffs. The trunk hose were wide, and in the Dutch fashion: they were ornamented at the knee with rows of puffed ribbons, the garters being tied at the sides with a large bow. The shoe rose and hat were extravagantly large; independently of that, the dress is simple and elegant, and the most picturesque of any worn by gentlemen for a long time previous.

\section{THE COMMONWEALTH, A.D. 1649-1660.}

The citizens of this period were more distinguished for the plainness than the costliness of their attire. A revulsion of

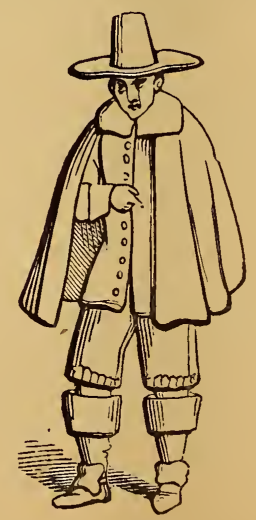

feeling had taken place in the minds of the Puritans, as a great number of the people were termed, against all superfluities or 
gaudiness of dress. Simplicity, bordering on ugliness, was the prevailing type, as the figure before us proves. A description of Cromwell, by Sir Philip Warwick, as he observed him in Parliament before he became a great man, is doubly interesting as a description of the dress of the period, and also as an expression of opinion on the man and his personal appearance. He says, "The first time that ever I took notice of him was in the beginning of the Parliament held in November, 1640, when I vainly thought myself a courtly young gentleman, for we courtiers valued ourselves much upon our good clothes. I came into the house one morning well clad, and perceived a gentleman speaking, whom I knew not, very ordinarily apparelled, for it was a plain cloth suit, which seemed to have been made by an ill-country tailor, his linen was plain, and not very clean; and I remember a speck or two of blood upon his little band, which was not much larger than his collar; his hat was without a hatband, his stature was of a good size, and his sword was stuck close to his side."

It may well be conceived that when Cromwell attained the ascendancy, that plainness of attire was extensively adapted. The fashion of the later years of the Protectorate is shown on the effigy of Hyacinth Taverel, 1657, in Morley Church, Derbyshire. The dress is that of an elderly gentleman, such as would be worn by a merchant or gentleman of the period. $\mathrm{He}$ wears a long open gown, with hanging sleeves, buttoned from the shoulder; the plain falling band, close scull-cap, tight vest, and full breeches, sparingly ornamented, bespeak the quiet well-to-do citizen.

We are approaching a time more interesting to tailors, as we now hear of a complete suite consisting of a coat, waistcoat, and breeches; for under the date of 1659 , Holmes gives the following description of a gentleman's dress: "A short-waisted doublet and petticoat-breeches, the lining being lower than the breeches, is tied above the knees; the breeches are ornamented with ribands up to the pocket, and half their breadth upon the thigh; the waistband is set about with riband, and the shirt hanging out over them. These petticoat-breeches at length assumed the shape of the skirts or bases to the doublets and jerkins in Henry VIII.'s time; and with the usual caprice of fashion, the doublet or jacket, which was so short at the beginning of this reign that it scarcely came below the breast, was, towards the conclusion of it, elongated to the middle of the thigh, with sleeves to the elbows, terminated by rows and bunches of ribands, from under which bulged forth the sleeve of the shirt, ruffed and adorned also profusely with ribands; in this shape, with buttons and button-holes all down the front, it became in fact a coat." 


\section{CHARLES II., A.D. 1660-1685.}

The excess of display in dress, which had been repressed by the stern Puritans, recovered its sway and influence with the restoration to the throne of the dissolute King Charles II. Taste and elegance were abandoned for extravagance and folly; and the male costume which in the time of Charles I. had reached the highest point of picturesque splendour, degenerated and declined, and expired in the square coat, cocked-hat, fullbottomed wig, and jack-boots of the following century. A few fantastical additions were made to the Vandyke costume, which they injured, but did not entirely destroy. The doublet was made exceedingly short, open in front, without any under vest, and displaying a rich shirt, which bulged out from it under the waistband of the loose breeches, which, as well as the large, full sleeves, were exceedingly ornamented with points and ribands.

As early as the year 1658 petticoat-breeches had made their appearance in England; and the fashion of wearing large stirop hose, or stockings two yards wide at the top, with points through several eyelet holes, by which they were made fast to the petticoat-breeches by a single row of pointed ribands hanging at the bottom, was brought to Chester from France in that year by one William Ravenscraft.

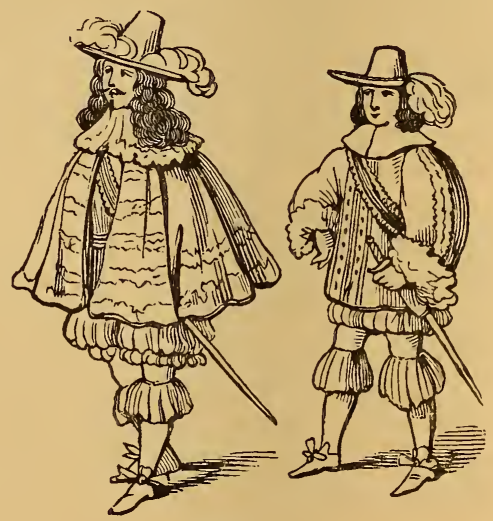

The cut here engraved is that of a nobleman and footman. The fashions were brought from France, where Charles II. had so long resided. The hat was worn with a broad brim, upon which reposed a heap of feathers; a falling band of richest lace enveloped the neck. The short cloak usually slung loosely across the shoulders or carried on the arm was edged deep with 
gold lace, as was also the doublet, which was long and straight, swelling outward from the waist, and wide petticoat-breeches puffed forth beneath, ornamented with rows of ribbons above the knees, and deep lace ruffles beneath them.

Charles II., when in exile in Jersey, according to the notes to "Grammont's Memoirs," wrote under date of January 14th, 1649: "Prodgers would have you (beside the embroidered suite) bring me a plain riding-suite, with an innocent coate, the suites I have, for horsebacke being so spotted and spoiled that they are not to be seen out of this island. The lining of the coate and the petit toes are referred to your discretion, provided there would be nothing missing when it comes to be put on. I due not remember (if) there was a belt or a hat band in your directions for the embroidered suite and those are so necessary, you must not forget them."

In an inventory of apparel provided for Charles II. in 1679, we find a complete suit of one material under the familiar designation of coat, waistcoat, and breeches. Pantaloons are mentioned in the same inventory, and a yard and a half of lutestring allowed for them. Holland drawers and flannel and cotton drawers are also among the items.

The inimitable Pepys, in his "Diary," gives us an idea of the clothes he wore, and also the cost. October 30th, 1662, he says : " $£ 43$ worse than I was last month, but it hath chiefly arisen from my laying out in clothes for myself and wife, viz., for her about $£ 1 \%$, and for myself about $£ 55$, or thereabouts, having made myself a velvet cloak, two new cloth skirts, black, plain both; a new shag gown, trimmed with gold buttons and twist; with a new hat, and silk tops for my legs; two periwigs, one whereof cost me $£ 3$, and the other 40s. I have worn neither yet, but I will begin next month, God willing." Under November 30th, he writes: "Put on my best black suit, trimmed with scarlet ribbons, very neat, with my cloak lined with velvet, and a new beaver, which altogether is verv noble." Under the date June 1st, 1664, he writes: "After dinner I put on my new camelot suit, the best that I ever wore in my life, the suit costing me more than £24." June 11th, he notes : "Walking in the gallery at Whitehall, I find the ladies of honour dressed in their riding garbs, with coats and doublets with deep skirts, just for all the world like mine, and their doublets buttoned up the breast, with periwigs and with hats; so that, only for a long petticoat dragging under their men's coat, nobody would take them for women in any point whatever; which was an odd sight, and a sight that did not please me."

The expense of a gentleman's dress of this period may be imagined from the following curious tailor's bill for a suit of 
clothes made for the Duchess of Portsmouth to appear in at a fancy dress ball, \&c., \&c., \&c.

"For making a dove-color'd and silk brocade coat, Rhingrave breeches and cannons, the coat lined with white lutestring, and interlined with camblett; the breeches lined with lutestring, and lutestring drawers, seamed all over with a scarlet and silver lace; sleeves and cannons whipt and laced with a scarlet and silver lace and a point lace ; trimmed with a scarlet figured, and plain sattin ribbon, and scarlet and silver twist....................

Canvas, buckram, silk, thread, galloon and shamey pockets ......................

For fine camblett to interline the coat........

For silver thread for button-holes .........

For 6 dozen of scarlet and silver vellam buttons. For $\frac{1}{2}$ dozen of breast buttons $. . . \ldots \ldots \ldots .$.

For 10 yards of rich brocade at 28.......... 1400

For 8 yards of lutestring to line the coat, breeches, and drawers, at 8s. per yard......

For a pair of silk stockings ..............

For an embroidered belt and garters .........

For 36 yards of scarlet figured ribbon, at 18d.

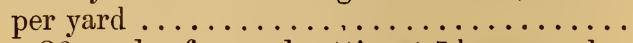

For 36 yards of second sattin, at 5 d. per yard..

For 75 yards of scarlet and silver twist ...... For 22 yards of scarlet and silver vellam lace, for coat and cannons, at 18s. per yard...... $19 \begin{array}{lll}16 & 0\end{array}$ $\begin{array}{lllll}\text { For } 4 \text { yards } \frac{1}{2} \text { of narrow lace for button-holes. . } & 0 & 12 & 9\end{array}$

For 1 piece of scarlet................ 1120

For a black beaver hat .............. $210 \quad 0$

For a scarlet and silver edging to the hat $\ldots . .110$

For 36 yards of scarlet taffaty ribbon $\ldots \ldots \ldots .0018 \quad 0$

Totall is.... $56 \quad 15$ 9."

The ordinary dress of the commonalty was of a simpler form. Thus in the comedy called "The Factious Citizen," 1685, a fop from the West-end of London, is thus told how to disguise himself as a steady citizen-" Off with your clothes, your sword, wig, and hat, put yourself nimbly into a suit of black grogram below the knee, a broad-skirted doublet, a girdle about the middle, and a short black cloak, squirted down before with black taffity; a broad-brim'd hat, with a great twisted hat-band, with a rose at the end of it. Your hair is slink enough, and of precise cut, without your periwig." 
Oct. 8th, 1666, Pepys writes:- "The king hath yesterday in council declared his resolution of setting a fashion for clothes, which he will never alter;" and on the 15th of the same month he says :- "This day the king begun to put on his vest, and I did see several persons of the House of Lords, and Commons too, great courtiers, who are in it; being a long cassock close to the body, of long cloth, and pinked with white silk under it, and a coat over it, and the legs ruffled with white ribbon, like a pigeon's leg; and on the whole I wish the king may keep it, for it is a very fine and handsome garment." Charles altered the trimming of this dress very soon; for, under October 17, Pepys says, "The court is full of vests; only my Lord St. Albans not pinked, but plain black; and they say the king says, the pinking upon white makes them look too much like magpies, and hath bespoken one of plain velvet."

That Charles failed in his resolve is certain, but it is equally true that to this freak we owe the origin of our present style of dress. In the cassock descending to the knees we trace the long waistcoat, and to the coat which covered it, the various styles of coats, which culminated in our English frock coat.

The summer dress of a gentleman at this period was a longskirted coat, single-breasted, with holes and buttons placed closely together from the top to the bottom, the pocket-holes are without flaps, but have three buttons on the lower part, and three imitation holes above, very large cuffs, edged with lace, and a gay shoulder-knot, an enormous powdered wig covered the head, while the hat was carried under the arm. The waistcoat reached down to the knees. The stockings are rolled over the breeches above the knees, so that the breeches are scarcely perceptible.

In winter this dress was covered by a cloak, and the hands kept warm by a muff, which is suspended from the neck by a ribbon, and decorated by a bunch of various coloured ribbons. This effeminate custom was very general, for we read that no young dandy of these days appeared in winter without one. In a ballad describing the fair upon the Thames in 1683-4, mention is made of-

"A spark of the bar, with his cane and his muff."

The liveries of the City of London were anciently distinguished by a peculiarity of costume, and its colour denoted the company to which the wearer belonged. No mention of these "liveries" occurs, however, before the time of Edward I. When that king rode in procession through London in 1329, after his marriage at Canterbury, six hundred of the citizens of London rode with the rest, in one livery of red and white, with the cognisances of their mysteries (or trades) embroidered on their 
sleeves. 'The members of Chaucer's Canterbury Pilgrims, who were tradesmen of London, he describes as

"Clothed in a livery

Of a solemne and greate fraternity."

Thus, the Grocers' Company, in 1414, were distinguished by a livery of scarlet and green, which was fourteen years afterwards changed to scarlet and black. The Leather-sellers wore gowns of black cloth, trimmed with fur, the hood being red and black; or parti-coloured, as before mentioned; the cap was of dark cloth.

It was usual with the members of each company to provide themselves once a year with a suit of livery, which was purchased by the wardens, who had a deposit of one penny when it was ordered, forty pence more when it was bought, and the balance when it was delivered. It was usual for the Lord Mayor to have a distinct livery of his own colours; and any member of the same company wishing for it for his own wear, might obtain it by sending the mayor a sum of money in a purse (which must at the least be twenty shillings), as "a benevolence," or part payment, for which the mayor delivered to him four yards of cloth for a gown "of his own livery," which previous to 1516 was generally "rayed" or "striped."

\section{JAMES II., WILLIAM, AND MARY, A.D. 1685-1702.}

There were so few changes during the above short reigns, that they are scarcely worthy of record. The petticoat-breeches were again exchanged for those which tied beneath the knee, but the latter were made to sit closer than formerly, and the stockings drawn over them to the middle of the thigh. The originals of the long-skirted, angular coats of these reigns, says Fairholt_-and which have descended to us with many variations yet preserving their real character intact, in spite of their taking all shapes and bearing many names-may be traced to Charles II., who, as Evelyn informs us, put on solemnly a long vest of dark cloth, with a determination never to alter it. From some prints of the time we gather that the coats were single-breasted, with about two dozen holes and buttons down the front, three pointed flaps on the hips, no waist seam, and sleeves with broad cuffs, ornamented with three buttons. The ladies of this period seemed to have adopted the objectionable practice of copying men's dress. They wore a man's jacket, cravat, and laced hat, and adopted the male mode of wearing the hat beneath the arm.

These figures give us the costume of the nobility and gentry 
of the day. The hat of the gentleman is edged with gold lace, the low crown of it is covered by feathers. The coat, which was generally decorated with lace and embroidery down the

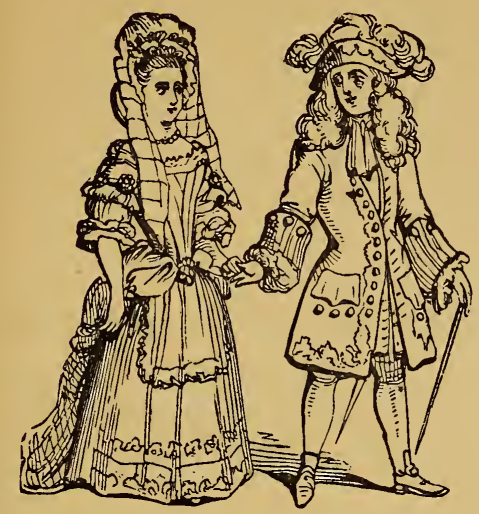

edges and seams and around the pockets, has sleeves ending in enormous cuffs ornamented with blind holes and buttons. The favourite colour of the cloth was claret.

\section{COSTUME OF THE 18TH CENTURY. QUEEN ANNE, A.D. 1702-1714.}

At the commencement of the 18 th century we approach a period when the style of dress worn is most interesting to tailors, for the clothes are of that form and fashion which more immediately preceded the present style of costume. The coats were cut single-breasted, with a stand collar, and without a waist seam. The skirts were made to spring out well behind, and to stand out well from the hips to make room for the sword, which was then a regular article of attire. To effect this the skirts were stiffened out with wire or buckram. Innumerable holes and buttons adorned the front from top to bottom; large flaps with pockets under were placed in the skirts. The waistcoats were similar in form, and reached half way down the thigh; and large pockets with flaps over them were inserted at the waist. The stockings were drawn up above the knees and over the breeches, which were almost hidden. The breeches were gartered below the knee. Some very curious descriptions of the costumes of this period may be found in the advertisements in the papers of various losses. For instance, a youth is lost, in the middle rank of life, who is of a fair complexion, light brown hair, having on a dark brown frieze coat doublebreasted on each side, with black buttons and button holes; a 
light drugget waistcoat; red shag breeches, striped with black stripes; and black stockings. In 1711 a lady's dress was advertised, of blue camlet, well laced with silver; being a coat, waistcoat, petticoat, hat and feather. In 1714, we are informed that Mr. John Osheal was robbed of a scarlet cloth suit, laced with broad gold lace, lined and faced with blue; a fine cinnamon cloth suit with plate buttons, the waistcoat fringed with a silk fringe of the same colour; and a rich yellow-flowered satin morning-gown, lined with a cherry-coloured satin, with a pocket on the right side.

\section{GEORGE I., A.D. 1714-1727.}

The same style of dress prevailed in this as in the preceding reigns, except that dandies had their coats to button at the waist, and the upper part open so as to display the frill of the shirt or the lace neck-tie.

The following engraving shows the gentleman's dress of the middle of the reign. 'T'he seated figure is intended for a thoughtless exquisite lolling on two chairs, with a snuff box in one hand and a tasselled cane in the other. The other figure, of a calculating shareholder, is dressed similarly, with a long vest

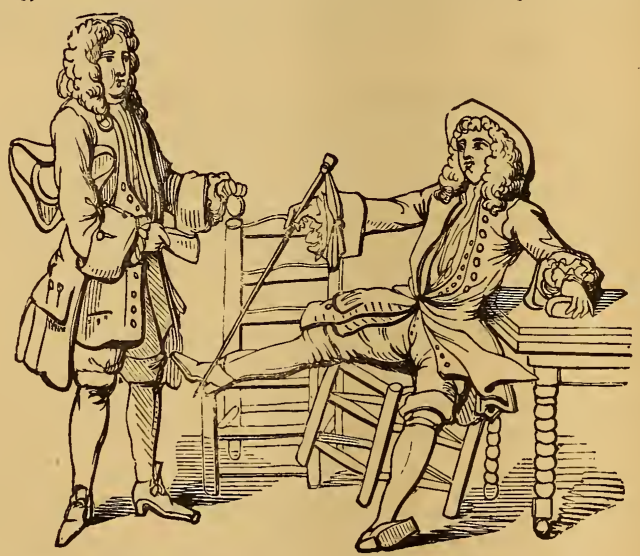

having innumerable buttons down the front, and a long coat with large flap pockets in the skirts.

\section{GEORGE II., A.D. 1727-1760.}

No alteration took place in the general style of dress. Variety was sought for, and found in the adoption of various styles of hats and wigs, which were certainly sufficiently remarkable, but are not within my province. Still, I may remark that the 
pigtail was introduced into fashion during this reign, as it is seen in prints bearing date 1745 . This king is said to have reviewed the Guards in 1727 habited in grey cloth, faced with purple, and with a purple feather in his hat. And the three elder princesses went to Richmond in riding habits, with hats and feathers, and periwigs.

In a work published in 1739 , there is shown on the frontispiece a view of the Mall, with figures. The dress of an old gentleman - who wears the same style as worn during the preceding twenty years, such as previously described -is well contrasted with a young buck of the period, who is shown wearing a coat which reaches down to his calves. The body sets well into the figure, while the skirts are full and project behind. The holes, buttons, and flaps are similar to the other coat. But it is distinguished by a very broad collar, almost as large as a cape, and which we now call a cape collar. This is a notable distinction from former styles, as previously coats have been shown with either a simple stand collar or no collar at all. The extreme length of the skirt is noticed by a satirist of the day, who says " that he never sees one of these exquisites cross the road on a muddy day without wishing to exclaim, 'Dear sir, do pray pin up your petticoats.'"

The costumes of the ordinary classes during the reigns of the two George's were exceedingly simple. They consisted of a plain coat buttoned up the front, and a long waistcoat reaching to the knees, both having very large pockets with flaps over them, plain bob wigs, hats slightly turned up, and high-quartered shoes.

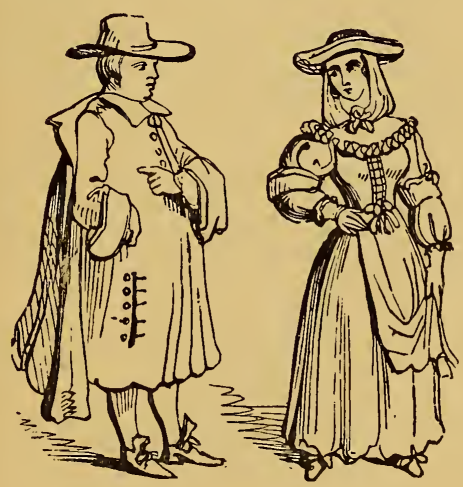

Some prints of this period furnish us with good examples of the costumes of the commonalty. An honest man buttoned up to the chin is submitted for the reader's inspection. The male figure wears a broad-brimmed hat, plain collar or falling band, his capacious-pocketed coat wrapping him to the knees, and high-heeled, long-toed shoes. 


\section{GEORGE III., A.D. 1760-1820.}

It was not until the middle of this reign that any modification in the style of dress took place. The skirts of the square-cut coats were unstiffened, the waist shortened, and the style of the late Court dress introduced. Cloth became the general material for the coat; velvet, silk, satin, and embroidery were reserved for Court dresses or waistcoats and breeches only. The latter were worn over the stocking as at present, and fastened first by buckles and afterwards by strings. The coat was made with lapels and a tail, being cut square in front above the hips, as well as the waistcoat. From this description we gather that the modern dress-coat style was now introduced; but it had flaps on the hips. The waistcoat was now deprived of its flaps, and made as ridiculously short as it had formerly been made unnecessarily long.

Until the period of the French Revolution, no very extraordinary change had taken place in male or female costume. The dresses of the gentlemen, which had then become less loose and capacious, so continued, and the waistcoat went not really below the waist. The coat had a collar, which gradually became larger and very high in the neck about 1786 .

In the year 1772 a new style of dress was introduced by some gentlemen belonging to the Macaroni Club, from which these dandies were called Macaronies. The coat was very short, reaching only to the hips, falling closely, and having a small turn and collar. It was edged with lace or braid, and decorated with frog buttons, tassels, and embroidery. The vest was worn reaching but little below the waist, and from the opening projected the frills of the shirt front. The breeches were tight, and were made of spotted or striped silk, with enormous bunches of strings at the knee; fob pockets were placed on either side, in each of which was carried a watch, from which depended bunches of chains and seals.

The engraving next given represents a lady and gentleman attired in fashionable riding dresses of 1786 . The lady wears a full habit with a short waist and a large collar, and with a shoulder cape. The gentleman wears an exceedingly long-tailed coat cut away in front like a sparrow-tail and trimmed with very large buttons. The vest is very short. The breeches are of buckskin buttoned at the knee, but tied above and below it with bunches of ribbons. The long-tailed coats with broad collars, and the skirts cut away to a sparrow-tail shape, became the fashion; broad-skirted coats being only worn by old gentlemen.

The French Revolution of 1789 produced a very decided effect upon English dress. To this period we are indebted for 
the introduction of the present uncomfortable and ill-suited covering for the head commonly known as the chimney-pot hat. The first shape was that of a sugar-loaf, and it was worn over long-flowing powdered hair. A loose cravat of white cambric, tied in a large bow, surmounted a frilled shirt. A long green coat with a high collar, tight-fitting sleeves, and small cuffs, was now worn. It was cut like a Newmarket coat, sloping away from the chest, where it would scarcely button; the skirts were broad and stuck out from the body as if interlined with buckram. A white waistcoat with red stripes graced the body, whilst the lower part was covered by pantaloons which buttoned midway up the thigh. The two fobs, with appendages, are apparent, and the lower extremities are covered by short top-boots.

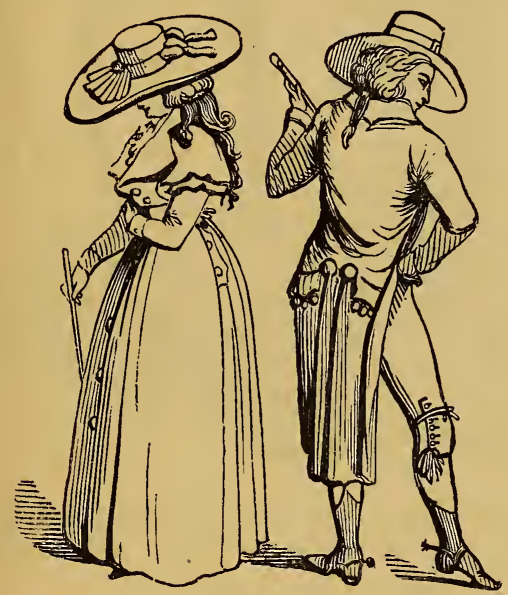

At the close of the eighteenth century English gentlemen had generally adopted the French style of costume. A variety of form is introduced by the addition of a pantean collar to the coat just described. It is the first specimen of the kind that . I have met with. The sleeves fit closely, and are ornamented by small ruffles at the wrist; the knee-breeches are of buckskin, which were said to be "immense taste," and his shoes tied with strings, buckles having become quite out of fashion. Pantaloons and Hessian boots, which are well calculated to display the figure of a well-built man, came into vogue the latter end of this century.

The last illustration brings us to the commencement of this century. One gentleman is wearing a single-breasted cut-away coat, breeches buttoning below the knee, stockings and shoes; the other dress is one familiar to us as depicting John Bull. The Newmarket cut away coat, the long breeches and top 
boots are all characteristic. We wonder as we gaze at the high and thick collar, the coloured striped vest, and the bunch

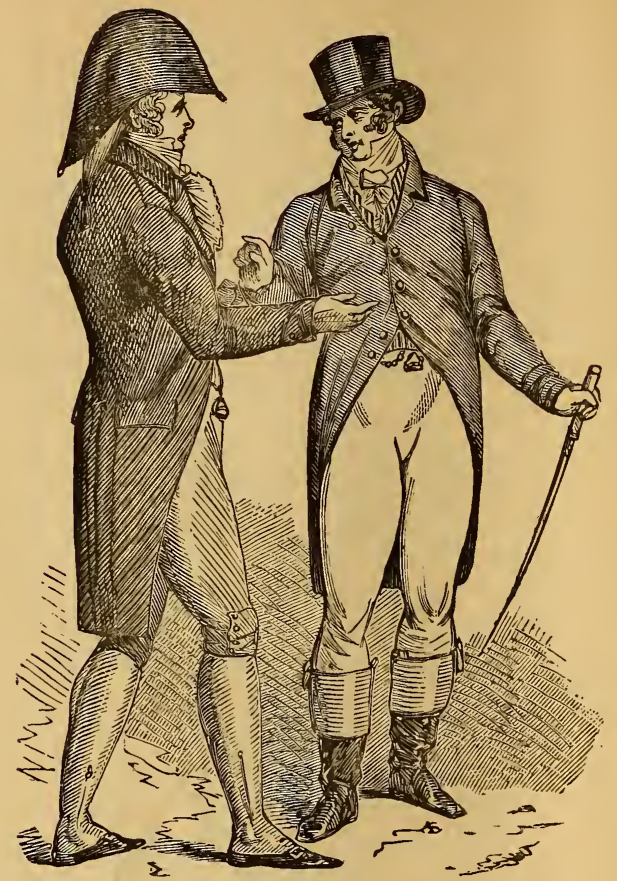

of seals hanging below the vest, not thinking that we in turn shall be looked upon with curiosity and wonder for our strange and peculiar taste and style of dress.

\section{GEORGE IV., A.D. 1820-1830.}

After having ruled for nine years as Prince Regent, the Prince of Wales ascended the throne as George IV. in the year 1820. As a man, he was distinguished for his shapely figure, his polished manners, and fine taste in dress. His admirers used to call him the first gentleman in Europe. No other English king has paid such attention, or devoted so much time, to his personal adornment as George IV. He frequently spent several hours in consulting with his tailor and trying on his clothes, and devising improvements; some workmen were kept in attendance, so that the improvement which his majesty suggested one day might be tested on the next. To him is attributed the dictum, "that where you see a crease, there take out a fish." His majesty seems to have contended for the position 
Plate 1

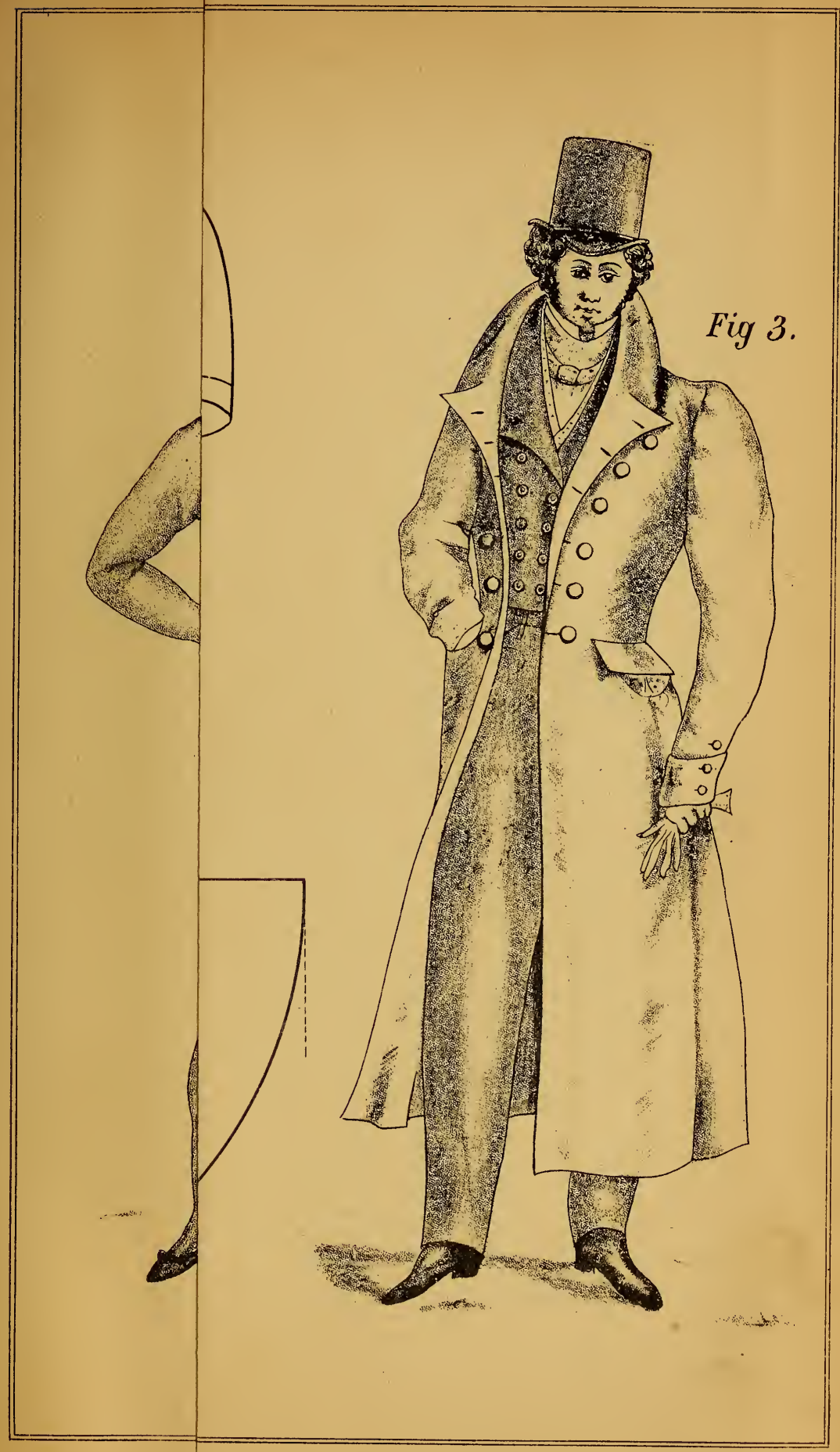





\section{Plate 1}

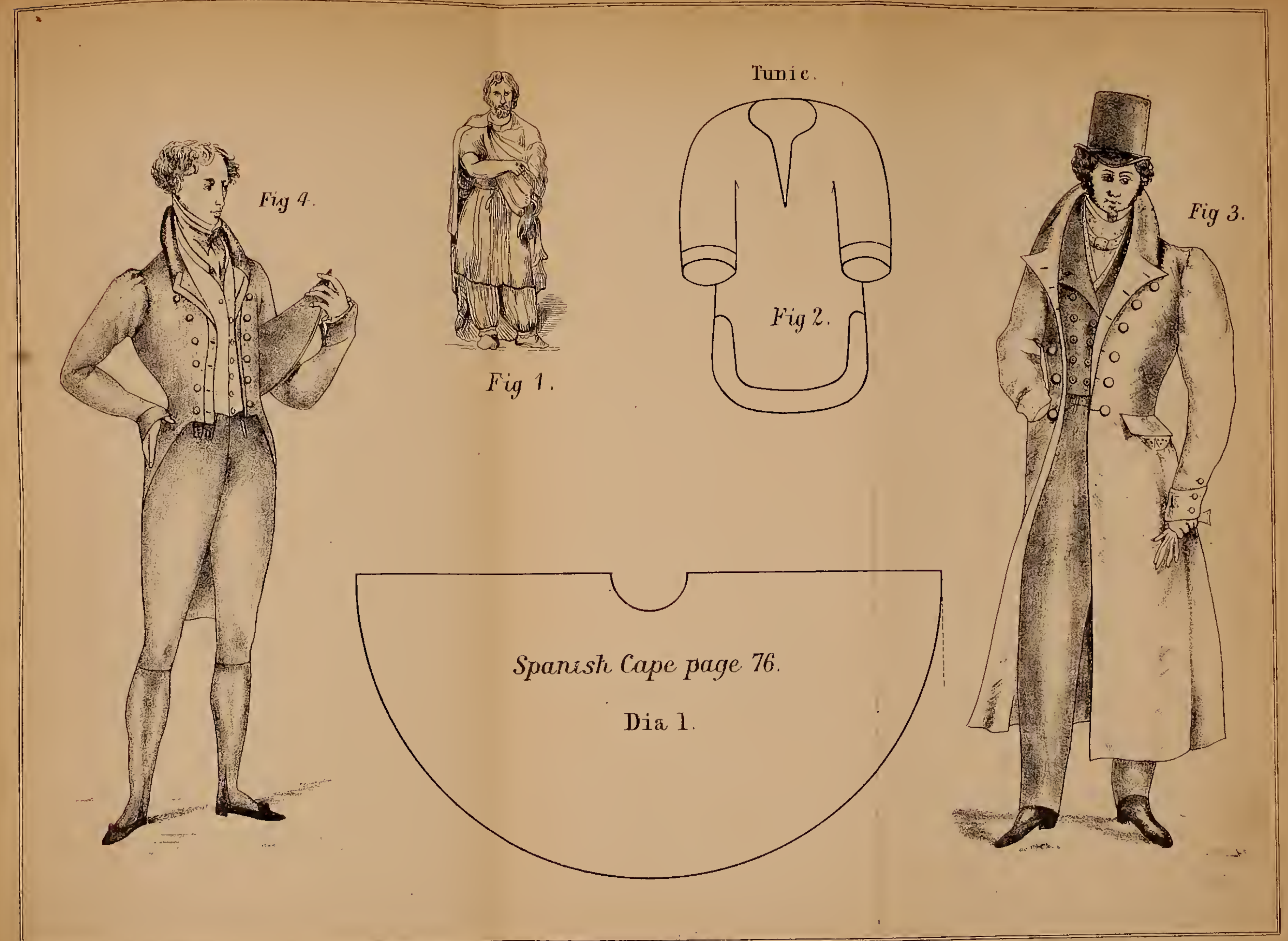



of leader of the fashion with Beau Brummell, a celebrated fop and leader of fashion of this period.

I am fortunately able to procure authentic records of this period from the early contemporaneous fashion-plates. In the "Cyclopædia of British Costume" for 1825, the first periodical of the kind, I observe that the fashionable evening dress is depicted as consisting of a green dress coat, cut very scantily, and with very narrow lapels; the sleeves are very large at top and tight in the arms; the shoulders are very narrow; the collar is of velvet, and ascends very high on the neck, and the crease rolls over, something like a horse-collar. See Fig. 4, Plate 1.

We are told that blues and bottle-green colours prevail, and that gilt buttons are worn on the blue dress coats, and patent gambroon ones on other colours; flaps are worn at the waist. A special remark is made that the coat is cut across the waist; from this we may infer that the cutting of coats across the waist had only been just introduced, especially as in a system of cutting published in 1820 the dress coat is given as an illustration of the method, and is without any waist-seam. The waistcoat is of white marcella, and is cut single-breasted, with a step stand collar. The breeches are close-fitting, and with a small fall. The material is of black kerseymere.

In the illustration of evening costumes for May, 1826, we are shown a blue dress coat with gilt buttons and velvet collar, a fancy coloured vest, with a blue under-vest, and flesh-coloured breeches. In the winter of the same year a green dress coat is given with a fancy velvet vest and a blue under vest. A remark is made respecting the colour of dress coats, that black cloth is also very much worn. We are also informed that frock coats are very prevalent at this time. The rolling-collar frock seems to be much in favour; they are made in length to the bend of the knee, and full in the skirt. Many of them are without trimming, but those braided are the most in demand. The trimming consists of a wide French braid down the front edges, round the collar, cuffs, \&c., with five volutes of wide braid down each side of the breast, in a military style. Doublebreasted frocks are particularly worn; they are made quite plain, and cut the same as the last, except the lapels and collar; there are six buttons down each lapel; the collar short, and button up under the chin.

The great coat shown on Fig. 3, Plate 1, is equally remarkable in style.

The instructions for making up collars is perhaps the most striking to us modern tailors. They say, "black velvet collars are very much in demand on dress coats, which are of a medium length; the stand-up part is three inches high, and 
the fall-down about two inches deep, and is made to turn into the gorge of the forepart about three inches at the front end, and is made with a small neat step; the fall-down is drawn in so as to be of a curve at the bottom edge, and to set a little off the neck all the way round." To make this garment still more monstrous in appearance, "the sleeves are made very large upwards, with fine gathers on the top of the shoulders filled up with wadding; the size from the elbow to the hand is made nearly to fit the arm, with a long slit and with about four or five small buttons."

What can we say of the juvenile costumes, when we read that the Dutch skeleton dress is much in vogue? Its very name seems to shock us, which the appearance of our young friends in these "cribbed, cabined and confined" garments seems to increase rather than diminish. As if these narrow garments were not sufficiently unsightly, they were surmounted by that instrument of torture the stiff and starched frill. A vivid remembrance of discomfort arises in my mind as I gaze upon the unsuitable attire, and a conviction is forced upon me that our juveniles are better and more suitably clothed than at that period.

\section{WILLIAM IV., A.D. 1830-1837.}

The advent of William Duke of Clarence to the Throne, at the ripe age of 65 , had no appreciable effect on the fashions of the period. This might well be expected, especially as the late sovereign had devoted so much attention to the details of dress. Fortunately I am able to obtain precise information of the prevailing fashions from a fashion plate published in 1831, by G. Walker, of Southampton Street, Holborn.

Two styles of morning dress, or rather I should say of ordinary costume, are drawn. One figure is designed wearing a green dress coat, buff-coloured vest, and brown trousers. The dress coat is short-waisted, very scanty in front, and the skirts scarcely perceptible. The collar is very high at the back, the break broad, and the lapel narrow; to complete its hideous form, the sleeves are very narrow, quite close-fitting to the arm and wrist; but, to crown all, they are very large and full at the top. The waistcoat descends only to the waist, has a Prussian collar, buttons at the top hole, and leaves two open for the frilled shirt to project. The trousers fit closely to the legs, have gaiter bottoms, and are fastened beneath the foot by straps. The fronts are made up with a small fall. The second figure wears a plum-coloured frock coat, rolling to the bottom hole, and the skirts are very full. The sleeves and collar are 
similar in style to the dress coat. The vest is of a lavender colour, and is cut double-breasted, with a stand collar, and the buttons are placed in pairs. The trousers are drab kersey, and similar in form to those just described. For evening dress, a blue dress coat, with gilt buttons, a roll collar lavender vest, and black dress trousers are worn. The over garments on the plate are brown cloth cloaks, with cord and tassels, and fur collars, and double-breasted frock great coats, with flaps on hips, and pockets under. Ladies' riding habits were simply ugly; they were made double-breasted, with high stand collars and lapels; sleeves of that absurd shape known at the time as the legof-mutton sleeve, very large at top, and equally small at the wrist. This style of habit induced the ladies to imitate the gentlemen's equally unsightly style of neck gear, known as the stock.

\section{VICTORIA, A.D., 1837.}

The historian of the Victorian era will be able to relate with pleasure and pride the great and abiding progress made by the English people in social and material well being, as well as in art and science. The adoption of free trade expanded our commerce to limits undreamt of by our forefathers; while the invention of new and improved means of locomotion broke down the natural barriers which divide peoples and countries, thereby dispelling mutual ignorance and jealousy, and promoting a just appreciation of each other's good qualities and virtues.

The general character of costume has not undergone any change during this reign, although there have been continued modifications and variations in styles and details. Fortunately the trade has been supplied throughout the greater part of this period with journals of fashion, to which ready reference could be made for any necessary information. Perhaps the most notable change in dress during this reign is to be observed amongst the labouring and working classes. The linen smock-frock, which had been for centuries the special dress of the rustic, and which seemed so well adapted to his various uses, besides being economical and easily cleansed, is now almost discarded, and the ordinary shooting-coat is gradually taking its place. Fustian and corduroy trousers, which are strong, cheap, and durable, were also worn by working men and the sons of small tradesmen, but now they are discarded and relegated to the lower orders, such as costermongers and day labourers; the mechanic thinks it beneath his dignity to wear them, and will not be seen with anything more common than tweed trousers. 
The most marked changes in dress have been in comparative trifles; for instance, coats have been worn sometimes long and sometimes short, having wide or narrow sleeves, full or close skirts, and plain cloth or velvet collars. Vests have been either single or double-breasted, and trousers have varied from the full peg-top, to the tight, close-fitting style. One feature is distinctly observable, the bright colours which men formerly wore, particularly in vests, are now no longer seen, except in remote agricultural districts. Another peculiarity worthy of observation is that loose garments, which were noted for their grace of drapery, such as the cloak, of which there were various modifications, such as the Talma, Inverness Cape, \&c., \&c., have been seldom worn, and coats which display the figure more perceptibly have taken their place.

Another change is specially worth noting. Some garments which were worn almost universally forty or fifty years ago are still retained, but only for special purposes. Breeches and pantaloons, formerly worn by all classes at all times, are now only worn by gentlemen for hunting and shooting, by agriculturalists for special purposes, and by out-door servants in livery. The dress coat, which was formerly used for general wear, is now reserved for dress occasions only, such as dinners, evening parties, and balls.

Although, as I have observed, the same type of dress has been worn during the whole of this reign as was initiated by King Charles II, and changes have only taken place in details, still these changes are so great that when the dress of the early is compared with the latter period, the contrast is so great that the older appears incongruous, void of good taste, and sometimes even ridiculous. The "cribbed, cabined, and confined" taste of the early part of this century has changed into a desire for ampler and more convenient and comfortable clothing. Gentlemen will not tolerate the idea of wearing coats with tight sleeves, puffed out at top, high rolling collars, resembling horse-collars, short waists, extremely narrow shoulders, and spare skirts, giving a mean and skimpy appearance to the figure, nor will they adopt the other extreme, of wearing skirts with such voluminous folds as to distort the human form. Neither will they put on the old style of vest, which was equally small and mean in appearance; nor the trousers, which were so well braced up at top and so tightly strapped down at bottom as to very much constrain all movements of the legs. Little boys in their skeleton dresses and large white collars are simply subjects for pitiable contemplation of past folly. The adoption of knickerbockers and sailor suits for boys is a great advance in children's dress, as they afford ease and comfort, which are so necessary to our juveniles. 
The History of modern British Costume really commences in the Reign of Charles II., dating from the time when he put on a new style of dress, which he officially declared he had resolved never to alter. This was in the year 1666. This dress is the basis on which our styles and types of dress have since been formed. The different transitions have been more in degree than in kind. In these various changes and adaptations, English taste and invention hold a worthy place. It may be asserted with confidence, that the world is indebted to England for the most gentlemanly garment of man's dress, the coat par excellence-the frock coat. This coat becomes both the young and the old, fills all the required purposes of dress, and combines elegance in appearance with comfort. Frenchmen have repeatedly laid claim to the introduction of this shape of garment; but the very name confounds their pretension. They term it a redingote, which is evidently a Frenchman's pronunciation of the English words, riding coat. According to Mons. Chapuis, "it was Montesquieu who introduced English fashions into France in the time of Louis XV.; and the redingote made its appearance in the reign of that Monarch in the year 1750 . Adversaries of the Anglo mania opposed the redingote (frock coat) with the habit a la Francaise" (dress coat). Frenchmen must, therefore, be credited with the fashioning of the dress coat. Some other garments were introduced at a more remote period. The round or smock-frocks most probably descended to us from the Saxon times. Breeches were also worn by the Saxons. They were reintroduced in the year 1654, to replace the absurdly wide trunk hose. Trousers of various shapes and degrees of fulness have been worn from time immemorial. They were worn in England at an early period, for Strutt observes, "That the trousers, posterior to the Conquest, ceased to form part of a gentleman's attire, and were confined to the rustics and lower class of the people." According to a print, they were reintroduced into Europe for gentlemen's wear in the reign of Napoleon I. Jackets are of undoubtedly English origin, as they are adaptations of an old English military garment called a jacke. The waistcoat is first mentioned in the latest inventories taken in the reign of Henry VIII. Gowns were the ordinary daily wear of an Englishman in the 16th and 17th centuries.

At one period richness was the great desideratum, whilst at others simplicity of attire was the great aim of dress. Eccentricity and extravagance often prevailed. Now the guiding principle in English style is fitness, the basis of good taste. Various appropriate garments are worn for different occasions. When freedom of movement is essential, we use the ample Norfolk blouse or shooting jacket; when repose is required, the 
lounge jacket or dressing gown. If elegance and refinement are desired, we put on the dress coat. Should richness, united to simplicity, be desired for ceremonial purposes, we adopt the modern Court dress. When effect or display is necessitated, we make use of the costume of the Charles period. For occasions of solemnity and dignity, we have appropriate drapery in the official gown. For general wear, we possess the morning coat. But when we wish to unite respectability of appearance with personal comfort, we dress in the English frock coat.

The impression made on the mind by careful comparison, some research, and a calm consideration of the various changes which have taken place in men's dress, results in the conviction that there has been a steady and progressive improvement in its general characteristics, its adaptation to our special wants, and confirmation to artistic requirements. The present style compares advantageously with the past. The essential purposes of dress are kept more in view. A desire is shown to preserve the beautiful outline of the human figure, or to remedy its defects by art, when possible. This is proved by the modern tailor's endeavours to construct elegant and comfortable garments. He designs coats with a rather broad shoulder, ample chest, a smaller, yet unrestrained waist, and a moderate amount of drapery, without any appearance of scantiness. He also makes loose or even ample garments, when freedom for muscular movement is required.

France was undoubtedly at one time the leader of fashions in men and women's dress. She dictated imperiously to other nations what they should or should not wear; and those dicta were servilely obeyed without any consideration of their suitability. The slavish following of some other nation's peculiarities has passed away as regards the fashions of men's attire in England. A healthier, purer, more original and becoming style of dress has been adopted. It is also better suited to our national peculiarities, and more in accordance with the dictates of sound sense and good taste. English style is essentially a combination of ease with elegance, and a suitable adaptation both in form and material to the purpose for which the garment is designed. The fact is patent and indisputable-English style in men's dress now predominates over French or any other fashion. So long as we preserve and cultivate our present good taste, just so long shall we deserve and keep the lead in gentlemen's costumes. Self-interest and a justifiable pride urge us to study to improve. Progress must be made. "Onward, ever onward," must be our motto. With increased knowledge will come a purer and more cultivated taste, a greater satisfaction to our minds, a higher reward in self-conscious dignity, and well-deserved honours. 
I fervently hope that the perusal of this necessarily imperfect sketch of the changes in the costumes of our forefathers, will both interest and instruct my young fellow craftsmen. I trust that while it may add to their knowledge, it will imbue them with a respect, if not a love, for their profession, and give them a consciousness of the usefulness and dignity of their calling. May it determine them to maintain its position as an art, and make them fully resolved to attain and preserve a worthy reputation as Artist Tailors.

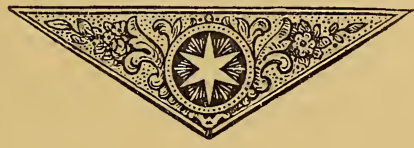




\section{PART II.}

The Art of Cutting in England has obtained pre-eminent renown in the estimation of the trade throughout the world. This is proved by the demand for English cutters in France, Germany, Spain, and America. In no other country are principles and systems of cutting so freely investigated, nor the results more generally promulgated. The demand for information increases. Investigation is extended to every department of our practice. The reason why is earnestly demanded. Our young craftsmen will not be satisfied with traditional rules for their guidance, nor remain content with methods which have only authority or usage to recommend them. The general character and intellectual status of our profession are being gradually elevated, in accordance with the mental and moral progress of the period. This spirit of enquiry and desire for knowledge may well be extended, and should not remain satisfied without knowing something of the origin, progress and present position of our art. This knowledge should be interesting to every intelligent tailor; for it will prove to him the many advantages he possesses in comparison with his predecessors. It may also show the student where ignorance or uncertain knowledge still prevails, and enable him to determine what principles in his judgment most accord with reason, and would conduce to his successful practice.

I purpose writing a short History of the Art of Cutting in England, and shall endeavour to trace the rise and progress of the various principles and methods of cutting, from the rule of thumb period, through the paper model time, to the commencement of breast measure methods, and thence to the origin of geometrical, admeasurement, and anatomical systems, with their various combinations. These remarks will be illustrated by diagrams copied from the various works I have consulted. It is feared that some omissions will be made and errors arise. Still, it is hoped that as this self-imposed duty is entered upon with an unprejudiced mind, that merit will be recognized where it exists, and censure awarded where it is deserved.

The only authors who have endeavoured to narrate the History of the Art of Cutting, and preserve from decay the memories of those old authors who contributed to form the 
literature of our trade, are Herr Klemm, jun., of Dresden, and Mons. A. Canneva, of Paris. All honour to them for their labours and research. But however learned and trustworthy their histories may be as records of the culture and progress of our trade on the Continent, they are necessarily very imperfect as a register of the names and works of our worthy predecessors in England. It is hoped that this narration will supply unavoidable omissions and imperfections. It has been my privilege to have brought these two works to the notice of the trade, through the columns of the "WEST-END GazeTte." Up to the present time no writer has endeavoured to rescue from oblivion the names and works of those English worthies who have enriched our profession with their knowledge. We are now reaping the advantages of their accumulated thoughts and labours, and gratitude alone dictates the duty to testify our appreciation of their efforts, and to make a record and due acknowledgment of them.

The materials for this work are fewer in number, and have been more difficult to collect and arrange, than could have been anticipated, because the names of many old authors are unknown, and their works consequently untraceable. The earliest works written were, probably, only published in the form of pamphlets for circulation in the trade. They were not considered sufficiently important for copies of them to be deposited in the library of the British Museum, interesting as they would have been to us at the present time. Still, as there has not been any account of the kind published, the collection and arrangement of the materials procured will considerably aid to form a more complete work in the future. Although I have an earnest desire to be thoroughly impartial, but yet appreciative of all the merit to be found in the various works that may be brought under my notice, still I feel that more interest will be excited by the great importance of the subject, than by my humble capacity to lay the facts and comments before my readers.

The origin of the art of cutting by system is unknown, and it seems almost impossible to discover it. We shall most probably find that it grew by degrees. First a simple rule, the result of experience, then other and more complex ones were introduced. Afterwards, these were compared and combined, and something like a system or method was evolved. The earliest traces of any method being published are to be found in a country where I should have little expected to find them. Still, our surprise will be modified if we reflect that Spain is much older than this country or France, and had made much earlier progress in art and civilization and those refinements in dress and manners which distinguish the civilized world. 
Herr Klemm says that the first and oldest work treating of the art of cutting, upon mathematical principles, was published in Seville in 1619, by Christopher Serrana. Its title is "The Geometry of the Art of Cutting." This information is very interesting, and creditable to Herr Klemm's research, but he is not accurate in stating that Serrana's work is the first and oldest published on the subject. I have discovered, by the aid of works in the British Museum, that a still older work on this subject was published, although our national library does not contain it. Its title is "Libro de geometrica practica quel al trada de toccanto officio de sastre, por Juan de Alcega," Madrid, 1589 (A Work on Practical Geometry relating to the Art of a Tailor, by John Alcega, Madrid, 1589). It may also be worth mentioning that another work in Spanish was published on this subject, but not so old as the two former. It is called "Geometria y trazas pertinencientes al officio de sastre, por Martin de Aduscar, Madrid, 1640" (Geometry and designs appertaining to the trade of a Tailor, by Martin de Aduscar, Madrid, 1640). Possibly there are some still older works in the Spanish language of which we have no knowledge. The above facts are, however, very interesting, because they inform us of a still older work than had been previously mentioned, and point out the direction where the earliest information can be found.

The foregoing remarks had been written and prepared for the press some twelve months, when, much to my surprise and gratification, the following notice from one of our journals was brought to me by a worthy colleague, Mr. J. W. West. It is as follows :-

"The Art Library at South Kensington has recently been enriched by the purchase of a very curious illustrated volume, entitled 'Libro de Geometrica Practica y Traca, \&c.,' Madrid, 1589, ' compuesto por Juan de Alcega,' and comprising on the title page a curious woodcut portrait of that worthy in the act of cutting cloth for a coat by the 'geometrical' method and device, which was the chief object of his life to commend to his brethren of the craft of tailoring. He was a very austere and resolute personage, and wrote from a high standpoint in respect to his craft. The Spanish text is embellished with numerous diagrams and complete instructions for 'cutting out.'"

My curiosity was aroused, and I determined, if possible, to see this very interesting relic of our art. I was very courteously received by the worthy librarian at South Kensington, and on explaining the object of my visit, the old work was brought most readily to me for inspection. The librarian informed me that the authorities had acquired this book for 125 francs, equal to $£ 5$ of our money. This ancient relic is in a good state of preservation. Its size is eleven and a half by eight inches. It is bound in parchment, somewhat discoloured by age. The title 
page is illustrated by a representation of a tailor, the veritable J uan Alcega himself, I presume. He is represented holding in his left hand a compass, and in his right hand he has a barra, or Spanish yard stick. A barra measures two inches less than an English yard. It is used for measuring and drawing lines in the same way that we use our yard sticks. A pair of scissors lies on his board, to the right, and a piece of some substance, chalk I inagine, or some similar substance, is ready to his hand. The figure is only visible from the waist upwards. He wears a doublet, plaited in front, surmounted by a frill at the neck, and the sleeves fit tightly.

Those who have the opportunity, and feel interested in the dress of a tailor of this period, may see a picture of a similar kind of the same period. It is the oldest portrait of a tailor that I have yet seen. It is exhibited in the National Gallery Room 14, No. 697. It was painted by an eminent Italian portrait painter named Maroni, about the middle of the 16th century. It is described in the catalogue as follows :-

"No. 697. The Portrait of a Tailor.-Tagliopanni, in a flannel jacket and red breeches, standing at his board, with the shears in his hand, about to cut a piece of black cloth. Half length, life size. Formerly in the Germanic Palace, Venice, purchased at Bergamo, in 1862, from Signor Federigo Frizzoni de Salis."

To a tailor this picture presents more interesting features than to an ordinary observer. The picture is skilfully painted, and the figure is now as clear and distinct as it was in the year when it was limned. That the tailor is an intelligent man, and of good social position, we should infer from the expression of his features, the style of his dress, and the ring on his finger. He is depicted standing with a pair of shears in hand, similar in pattern to our old-fashioned shears, regarding with a look of intelligent thoughtfulness a piece of black cloth, which he is about to cut. He is wearing a single-breasted jacket, buttoned up to the throat. It is close-fitting, the sleeves taper to the wrist, a strip of stuff forms a kind of narrow epaulette to the shoulder, and a stand collar is placed on the neck. The neck and wrists are trimmed with lace. The waist is girded by a narrow leather waist-belt, fastened with a buckle. The material is of a white woven texture, with a small pattern on it. The breeches are of a red coloured material, the tops alone are visible, they are made very large, seemingly plaited, and of the shape known as trunk hose.

This ancient work of Senor Alcega's bears on the title page the following inscription (in Spanish):

"A Treatise on Practical Geometry and Design relating to the Art 
of a Tailor, with instructions, showing how much cloth, silk, or other material is required for many kinds of garments, both for ladies and gentlemen. It also teaches how to cut out such garments tastefully and economically, with many other secrets and curiosities respecting this Art. Written by Juan de Alcega, native of the Province of Guipuzcoa, descendant of the house of Alcega. Dedicated to the very illustrious Senor Licenciada Tejada, of the Supreme Council of the King our Lord. Seen, examined, and printed by privilege in Madrid, at the office of William Drauy, book-printer, in the year 1589."

The instructions it contains are of the most meagre description. They simply tell how much material, according to the width, is required to cut certain garments; and the diagrams show how these garments are most economically taken from the cloth. The diagrams which I have inserted show how to cut from the cloth a loose coat and cape. The other diagrams are of a similar character. It furnishes no instructions for measuring, much less any method for constructing garments of various kinds for different figures.

I have copied the instructions given respecting these diagrams, so as to give a specimen of the small amount of information furnished to the tailors of that period:-

"A Cloth Coat and Cape (Plate 2, Dias. 1-6, and 8).-Open the cloth and place the cloak. The cape and the back are taken together. Take the sleeve and the skirt from the edge, and the forepart from the middle. The collar, facings, flaps, and welts are taken from the remaining pieces. That is all that is necessary to make the coat, as all is so clearly laid down."

The great interest attached to this work is solely on account of its age, and the fact that it is the oldest work on cutting in the world that we have at present any knowledge of. It is really a remarkable circumstance that we should possess a copy of such a work in England, and I consider myself extremely fortunate in discovering its existence, having the opportunity of seeing it, and bringing its present resting place to the knowledge of the trade.

Most persons would suppose that we were indebted to Frenchmen for the origin of rules for cutting, as France was so long the acknowledged dictator of taste and fashion in dress to the civilized world. But to my surprise I cannot find any trace of an earlier work than one published in the latter half of the seventeenth century.

Herr Klemm mentions in his "History of Cutting," that the earliest French work on the subject is that of Monsr. Benist Boullay, published in Paris in 1716. I have had the pleasure of seeing a still earlier work than the one mentioned, and by the same author. The book I refer to is in the Library of the Royal Institute of British Architects, Conduit Street, Regent 


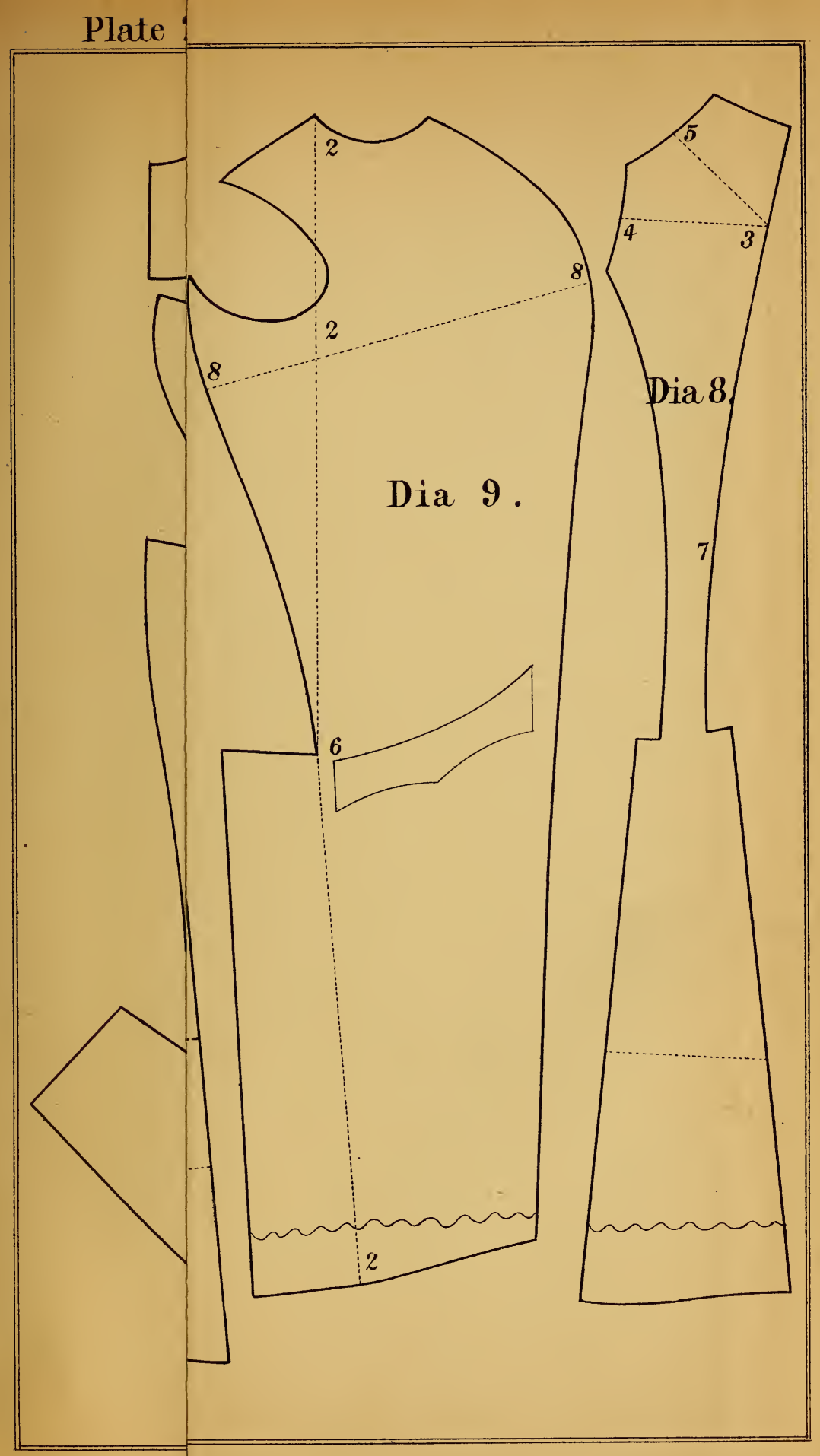



plate 2.

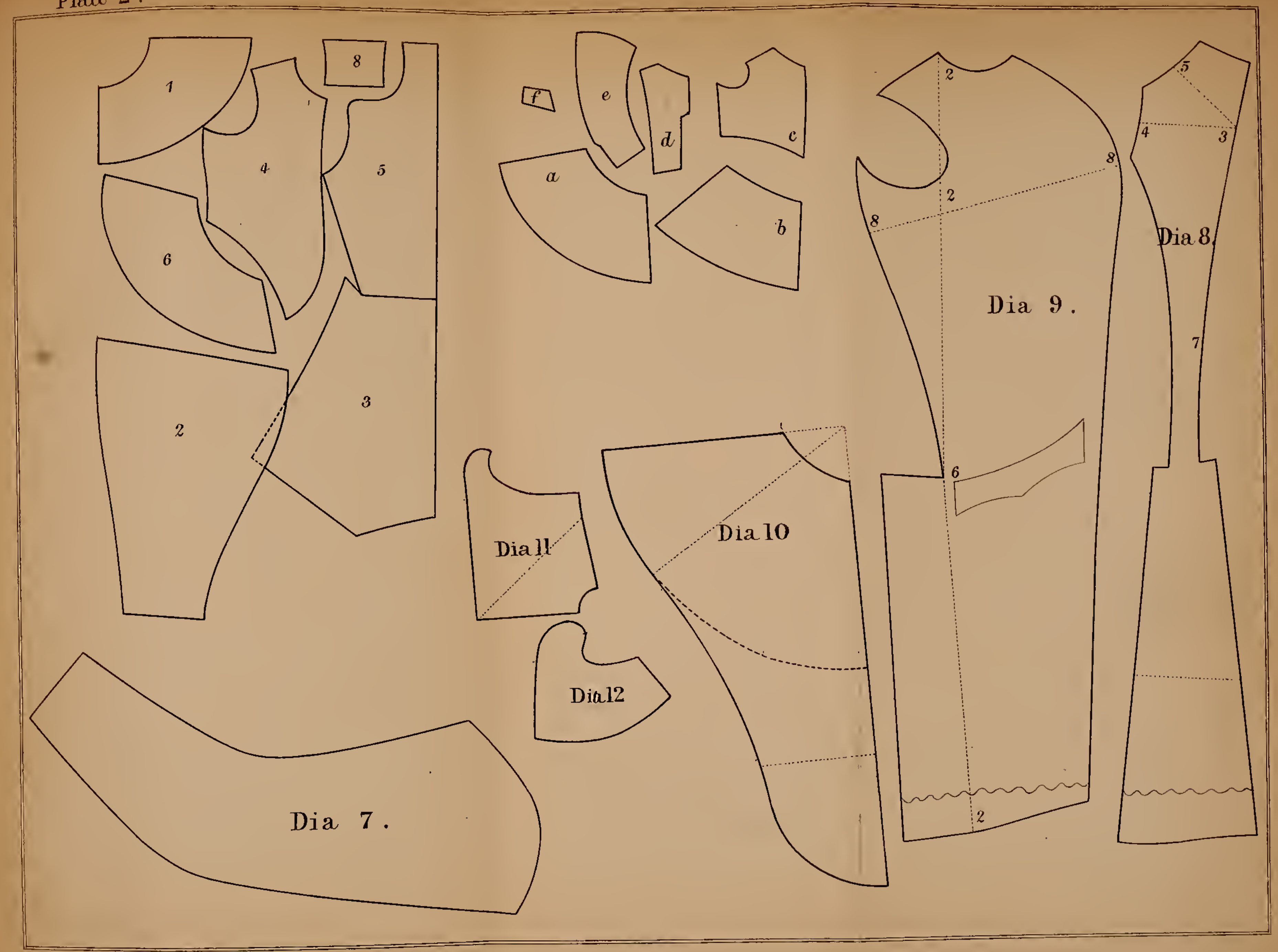



Street.* I feel that the age and scarcity of this work make it sufficiently interesting to warrant my introducing some extracts from it, and giving some copies of the diagrams. The title page reads as follows :- "THE SINCERE TAILOR, containing what is requisite to design, cut, and put together all the principal garments which are made by Tailors, by le Sieur B. Boullay. Published by Antoine Raffle, Paris, 1671. By permission of the King." "It is written in old French, and therefore rather difficult to understand. M. Boullay in his Introduction gives some very useful advice to young tailors, which is as relevant at the present day as at the time it was written, two hundred years ago. He says, "I intreat you, then, my dear friends, while you are yet young, to make yourselves masters of the profession you have chosen"; and again, "Firstly, it is essential not to make any error when taking the measures. It is very necessary to observe well a man before measuring him, so as to note his ordinary posture, and that without warning him, for he may stoop naturally, or hold himself erect, or else lean on one side or the other; if he expects that you are going to take his measure, he will think he is doing right to hold himself more erect than usual, and you will fail with your measure. For, as he is accustomed to stoop, the back part of your garment will be too short and the front too long. The contrary effects will take place if he stoops more than he usually does, the back will be long and the front short, which is one of the worst faults a coat can have."

The book contains diagrams and descriptions how to cut a royal cloak, a prince's robe, a round cape, a page's cape, \&c., a gentleman's coat, a poor man's coat, the pope's cape, \&c., \&c. No method of cutting is given, nor instruction how to place the patterns. How this book could effectually aid a tailor in his labours it is difficult to conceive. The full instructions which it gives respecting a poor man's coat are as follows :- "It is made all in one piece, namely, the body and the skirt, and the collar ought also to be of the same piece, principally on the back. It is not difficult, you only want to see the figures and take their measures."

The Diagrams 4-7, Plate 3, show us that the form of the poor man's coat was similar to the Chesterfield of the present day. On the top of the back is added the back part of the collar, the smallest is evidently the front part of the collar.

The Diagrams (A to F, Plate 2) of the gentleman's coat are six

* I am indebted to the kindness of C. J. Shoppee, Esq., architect, for the information that he had presented this work to the Library of the Royal Institute of British Architects, and also for an introduction to the librarian. I cheerfully take this opportunity of expressing my acknowledgments to both of these gentlemen for their courtesy and attention. 
in number. There are no instructions by which we could positively distinguish one part from the other. The coat is cut across the waist. We have here two skirts, a back one and a front one. The back skirt, I presume, was plaited in. The back part of the collar is allowed on top of the back, similar to the poor man's coat. The measures that should be taken, or how they should be applied, are left for the tailor to divine, for no such information is supplied by our author. His instructions are very simple. He says : "For a gentleman's coat the collar must be straight, and the front skirt also. The bottom of the coat takes a quarter and a half, and you must observe that the width requires to be increased about one-third more than the body. It must then be folded so as to reduce it to the required size. It is not necessary that all the stuff in the skirt should be plaited in, but care should be taken that the skirt is proportionate to the body, so that the front may lay straight. I am not able to judge of nor give instructions respecting the surplus, without seeing it."

The accompanying Diagrams $(10,11,12$, Plate 2$)$ of the pope's cape are interesting from their peculiarity, rarity, and antiquity.

The knowledge a tailor could gather from these diagrams and explanations is very limited, and would assist him but very little; still we must remember the primitive state of our art at this period, and whilst giving due honour to the author for his good intentions, make due allowance for this early effort to enlighten the trade. The interest and value which belongs to this book is the presumed fact, that it is the first work on the art of cutting published in France.

After having seen extracts from the earliest known works on cutting in Spanish and French, I come to another of more immediate interest, viz., the earliest known work on cutting published in England, entitled "The Taylor's Complete Guide." It was quite by accident that I discovered it, and it is with no small degree of pleasure that I bring its contents under the notice of the profession. That it positively is the oldest English work on the subject that has been published I am not prepared to assert, although the only references to it $I$ have seen point to that conclusion. Mr. Golding, one of our earliest authors, says, "Among the various publications on this subject (from that by a Society of Adepts in 1796) down to the present period," \&c., \&c., so that he evidently considers the work published by this said Society to be the oldest he knew of.

The following extract from a paper contributed to the American Tailor by Mr. J. C. Madison, one of its able Editors, is very noteworthy:

"It is interesting to read the works on cutting which were 
published during the earlier part of the century. The first, probably, that was ever published in this country was entitled 'The Tailor's Instructor, or a Comprehensive Analysis of the Elements of Cutting Garments of Every Kind.' The authors were James Queen and Wm. Lampsey. It was published in Philadelphia, at 53, South Third Street, in 1809. The book contains eight full-page engravings, which are finely executed. In the dedication the authors say: 'The following work will no doubt produce in your minds a degree of curiosity, as it is the first of the kind that has made its appearance in the United States, and, we believe, the second ever known in the English language." "

The statement that this work is the second of the kind published in the English language is very interesting, as it confirms my opinion that the "Taylor's Complete Guide," published in 1796, was really the first, considering that this American work is simply a reprint or copy of the English one, but with some additions. Some extracts which $\mathrm{Mr}$. Madison publishes from the American work are precisely the same, word for word, as those I have taken from the "Taylor's Complete Guide," and the diagrams given of the coat are almost facsimiles of those illustrated on Plate 2.

The "Taylor's Complete Guide" contains 163 pages of letterpress, dedication, preface, and introduction. The first part is devoted to the cutting of breeches, one diagram of which I have copied, the following portion is occupied with instructions to cut vests, and the remaining part to coats. I will give rather copious extracts of their instructions how to cut coats. One remark occurs to me here, which is, trousers are not even mentioned, much less instructions given how to cut them, so we may well conclude that they were not worn at all at this period.

The title is so full of promise and high sounding phrases, as to make the book appear almost ludicrous when we examine the contents. The promise and the performance are so very dissimilar. The Analysis of Beauty is simply non-existent, as far as this book is concerned. The grandiose and verbose diction contrasts forcibly with the meagreness of the information given. Still it is a very interesting specimen of our old authors, and as such worthy of our notice.

The full title is as follows:-

"The Taylor's Complete Guide, or a Comprehensive Analysis of Beauty and Elegance in Dress, containing rules for cutting out Garments of every kind, and fitting any person with the greatest accuracy and precision, adapted to all sizes, pointing out in the clearest manner the former errors in the profession, and the Method of rectifying what may have been done amiss, rendered plain and easy to the meanest capacity. Illustrated 
with Copper Plates. To which is added a description how to cut out and make the patent elastic Habits and Cloaths, without the usual seams, now in the highest estimation with the Nobility and Gentry, according to a patent granted by his Majesty. The whole Concerted and Devised by a Society of Adepts in the Profession. London, 1796."

\section{HOW TO MEASURE A THIN GENTLEMAN FOR A SINGLE- BREASTED COAT.}

"Previous to our beginning this business it may not be amiss to warn the student of the grave necessity there is of his being judiciously particular in learning from his customer the precise length he chooses to wear his coat, with how much of the ruling fashion he would wish to imbibe, with other particulars of buttons, pockets, \&c., for it is notorious that hundreds of suits of clothes have been returned upon the tailor's hands, by gentlemen leaving it to the tailor's own taste. The ideas of men are very different, especially in dress, for what is most pleasing to some is disgusting to others, therefore the safest and most certain mode of giving satisfaction is by a few questions touching the above purposes, and then proceed to measure.

"First, take the length from No. 1, at the top of the shoulder, or of the back down to the waist, and then continue it to the bottom of the skirts for the length; then from the back seam, half across the back, from No. 3 to No. 4 ; next to the elbow and down to the wrist, for the length of the sleeve; afterwards across the arm, as high as you can, then below the elbow, or as many times round the arm as you please. Observe that the gentleman, when you measure, holds his arm level with the shoulder, for too high would make the sleeve too long, and too low too short; then measure round the breast, as high as possible, next below at the belly and also over at the hips; then measure half over the breast, which will be as much as we conceive necessary, only with this remark, when you measure for the length of back, mind you nicely hit upon that mode that most pervades your employer's fancy, for by doing this you will facilitate his wishes, which may give a pleasing sanction to all the rest.

"After you have taken and marked all your measures, be sure that you keep them distinct, that two alike may not clash at one place, and by a kind of confusion, frustrate your ideas. As for your manner of marking, use the only clear method that may seem most familiar to you, and before you leave the gentleman, set down his particular requests in your book of directions, that when you have cut, finished, and brought the clothes home, should any dislike arise, you can have recourse to your minutes, taken from your customer's own mouth, which, if 
you have justly followed, will hold you blameless. A little caution of this kind, you will find, prevents both anxiety and doubt, and will reflect wisdom on your prudence, and in the end gain both credit and respect."

\section{OF THE POINTS AND MAXIMS OF CUTTING AND COMPLEATLY MAKING A COAT.-Dias. 7-8-9, Plate 2.}

"As we write for the inexperienced and uninformed, it may not be amiss for us to define and lay down a certain rule that may be a lasting standard for all such as are unacquainted with the real quantity of cloth necessary to make a coat; take the following method :-

"Measure by your yard the length of your coat, as you have taken it from your measure, to which add the length of your sleeve, these two added together will be the precise quantity requisite, and no less will do with any propriety.

"When the cloth is laid before you, do not omit to have recourse to the plate of the analysis of coats, and pay particular respect to the separated parts, the different modes and turnings that they effect, for until these are made (as it were) coincident with your own ideas, the maxims we lay down, we are fearful, will only serve to confuse, without answering the great end we wish to obtain by our labours. After you have sufficiently digested the plates, and your cloth being before you, mark down the back seam, as the plate directs, and strike the shape of the back upon the cloth, bearing the same similitude as the plate, and take care it answers to your measure in every part. Take a large back hollowing, for this will make your back skirts lap over well and not part behind, as is too often the case, to the abuse of decency.

"Be a little curious in the length of the back scye, should you make it long, see that the shoulder seam lies very high, and in order to prove that, when you lay your measure across the back, from No. 3 to No. 4. Dia. 8, then move the measure from No. 4 to No. 5, on the shoulder, and mark down the shoulder at the end of the measure for the shoulder seam; afterwards strike the mark of the back scye at the end of the measure, according to the plate, as low as you perceive it necessary; but be a little nice in this top of your back, and cut your back narrower at the shoulder across than it is at the bottom of the back scye.

"This maxim will make your sleeve, when all is united and put together, come up well on the shoulder, from which effect you will learn that if your back is broad your forepart must be broad also; in which case the sleeves cannot come up to the place they should be at, both the back and the forepart prevent it; but by cutting the back and forepart a little away, and 
adding so much to the sleeve, you may command the sleeve seam at the shoulder top, as much over the rounding of the bone as you please, but more of this hereafter.

"In order to finish the back, draw from the back scye to the hip, strike the back side seam as smart and neat as you can by inspection of the plate, and in the back seam be sure you do not begin to hollow till you come to the appropriate place of No. 7 , for should you do this you will disorder the economy and fitting of the whole coat; for by too much hollowing the back under the shoulder, you will force it to kick up and hang loose at the hip, which is a very great error. To find the true length of the waist, it must be cut from the top of the back slit (or what is called tack over) longer by three inches than the skirts. If the fashion should create a broader mode of making the backs at the hip than at present, and our student should not have considered this till practice has availed him of the methods more prompt to his purpose, let him mark out his narrow back that he has been used to with all its leading features, and add to the side seam as much as is required; but remember that whatever is added to the back must be taken from the forepart, and this will answer his purpose, and the rest of the forepart as Dia. 9, for on this depends the very continuity of the whole coat. Observe well the cut and contour of the plate, mind the round and prominency of the breast, for on this will depend the graceful seeming and elegance of the cut which is so requisite to display the beauty and perfection of human nature.

"To make the forepart answer to the back, lay the back upon the forepart, and form the same shape according to the plate down before. Extend your measure across from No. 8 to No. 8, and laying one-half of your back to the extent of your measure, mark the width of the forepart at the side seam, with a proper allowance for laying in, and also room before for pairing and making up the edge, with allowance for projection at the end of the holes; then across for the belly, and make it somewhat less in proportion to the measure as smartness and neatness may require, and the same at the hip, and mark your skirt agreeable to the plate, and the same length as the back skirt, then make the forepart skirt.

"Notwithstanding we have said so much about the cutting, measuring, and making of a coat, yet we have a few most essential points further to propound to our pupil, which he will find of serious consideration, and tantamount to his purpose, as they are the very leading features which symmetry has prescribed to facilitate and harmonize the whole.

"In the first place we must inform him that however essential every component part is to the unity of the thing intended, yet there are a few prevailing causes which give energy to the 
theme, and which cannot be dispensed with if the coat is designed to fit neat, clean, and clever in every part. Observe the following rule, that it is a maxim in our theory that the top of the coat commands the bottom; for instance, should you want to find where the square must be marked, this must be done by laying your measure or yard, or anything you have that is long enough, first at the shoulder point in Dia. 9, and continue it straight down to the hip, where it closes to, and carry it down the skirt to the bottom; and where it falls at the extreme end of the skirt, there you must mark your place for your square.

"When you plait up the coat you must mind that the fore plaits are exactly in a line from the top of the shoulder to the hip, and down to the bottom of the skirts, for your square will be always in a right line from the shoulder and the hip. Thus far we do infer the shoulder point always rules your square, and always will, let the range of fashion be ever so preposterous. Notwithstanding any alteration of long or short waists, narrow or broad backs, this rule is plenarily just, and cannot be dispensed with for any elegant coat whatsoever.

"The next great point to compleat the cutting lays in the symmetry of the forepart, which is perfectly described on Dia. 9, which bears a just proportion, and must be the same in likelihood and similitude when marked and cut upon your cloth; and be sure you note the following maxim, that is to lay a line from the hip to the shoulder point at the gorget, I mean the point at No. 2 in the plate at the shoulder, and No. 2 at the scye arm-hole and at the hip; and be assured of this, that if those three leading points are not all in a direct line, that it will baffle the very hope of possibility ever to make the coat fit. This maxim we do affirm to be an indispensable certainty, and though but little understood by the trade, we give it as its choicest criterion, and of much more value to our pupil than any rule in the whole branch of business.

"After your forepart is fashioned, after the manner we speak of, and those other rules strictly adhered to, you must be careful that your back and forepart are both of a length; and in order to ascertain this matter truly, lay your back and forepart together at the hip, and hold them fast, and also lay bold of the corner of the back at the top of the neck at the shoulder seam, and try how you can make it reach without straining, and then strike your shoulder across for your forepart shoulder seam ; and that point of the back that is the shoulder point, must fall just in the middle of the shoulder seam. This will ever be a judicious guide for all people. When the foreparts and backs are in this trim, be assured that the very power of distortion is destroyed, your practice being commensurate with symmetry, and error is totally divested of its power. 
"With respect to the sleeve, we must still urge the necessity of strictly adhering to the cut and manner of the plate. Take care you do not hollow your fore seam otherwise than as we direct. Cut the sleeve all down the fore seam in manner of the sleeve in Dia. 7, Plate 2, a little hollow from the top to the bend of the arm, very full and nearly straight; and then form the hollow down to the hand, according to the success of the figure in the plate, full, and to fall off agreeably; this will prevent the cocking up so much complained of. Though this mode of practice may differ from your own, and create a surprise at the novelty of the method, you may rest assured it is a paradox not more strange than true.

"In order more fully to demonstrate this matter to our learner, we would have him turn his thoughts upon the cut of the patent sleeves, which are made without seams either before or behind, and which are known to fit neater and much better than those that are made with seams; and those must be straight, not in the least hollowed, as reason must suggest to every searcher of the art. Have an eye upon the men's sewing of the sleeve, lest by bad practice they should prevent its fitting at the arm-holes.

"Observe they lock in the inside at the top four inches down, and take it in less than the outside full an inch; this maxim will compel it to fit the scye, and not appear too full under the arm, as is too frequently the case by the generality of the trade. This has long been a most egregious error, and has escaped the observation of many, whose studious application has given them great credit in this particular, as well as other brilliant efforts in many other parts of the business, to the attainment of the matter we are treating of, which has ever distinguished them by the neatness of their work."

A chapter "Of the Making a Straight Frock, for either Gentleman or Groom;" and another on "Great Coats," complete the instructions for cutting coats. Diagrams of these coats are given, some without the indispensable guide line. On one diagram a second line is introduced. It starts from the shoulder scye point, runs through the scye, cuts the side seam point at the waist, and terminates at the bottom; but the purpose or use of this line it is difficult to discern, as no reference is made to it in the letterpress.

The coat system just described is scarcely entitled to be called a system. It is more properly only the embryo of a method, as it contains but one line, and that is rather a line for guidance than construction, as it is applied after the model is drafted. This is the first departure from the "rock of eye" plan, pure and simple, and the practice of cutting by patterns. Our special attention should be directed to this guide line drawn 


\section{Plate \&}

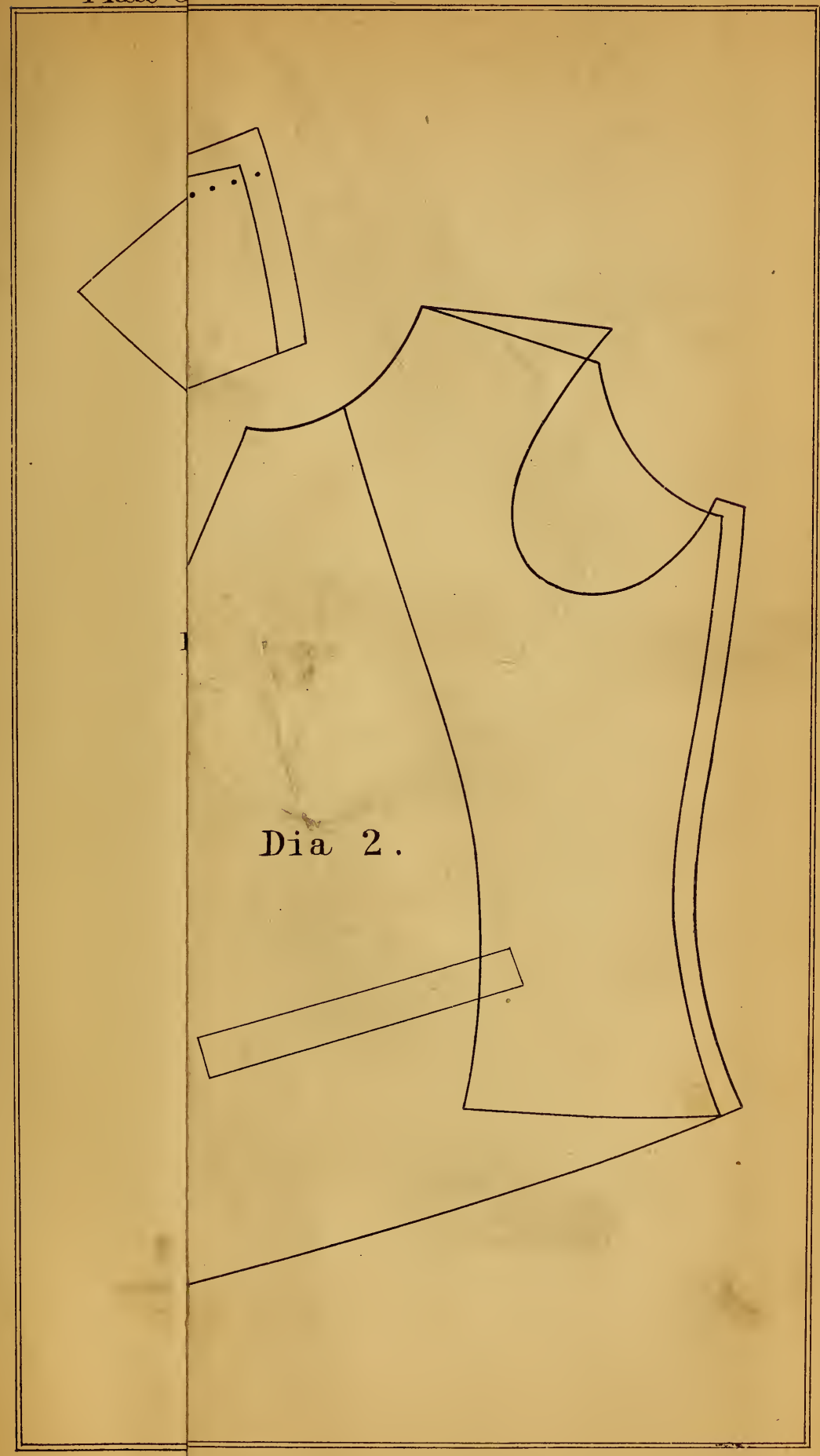





\section{plate 3}

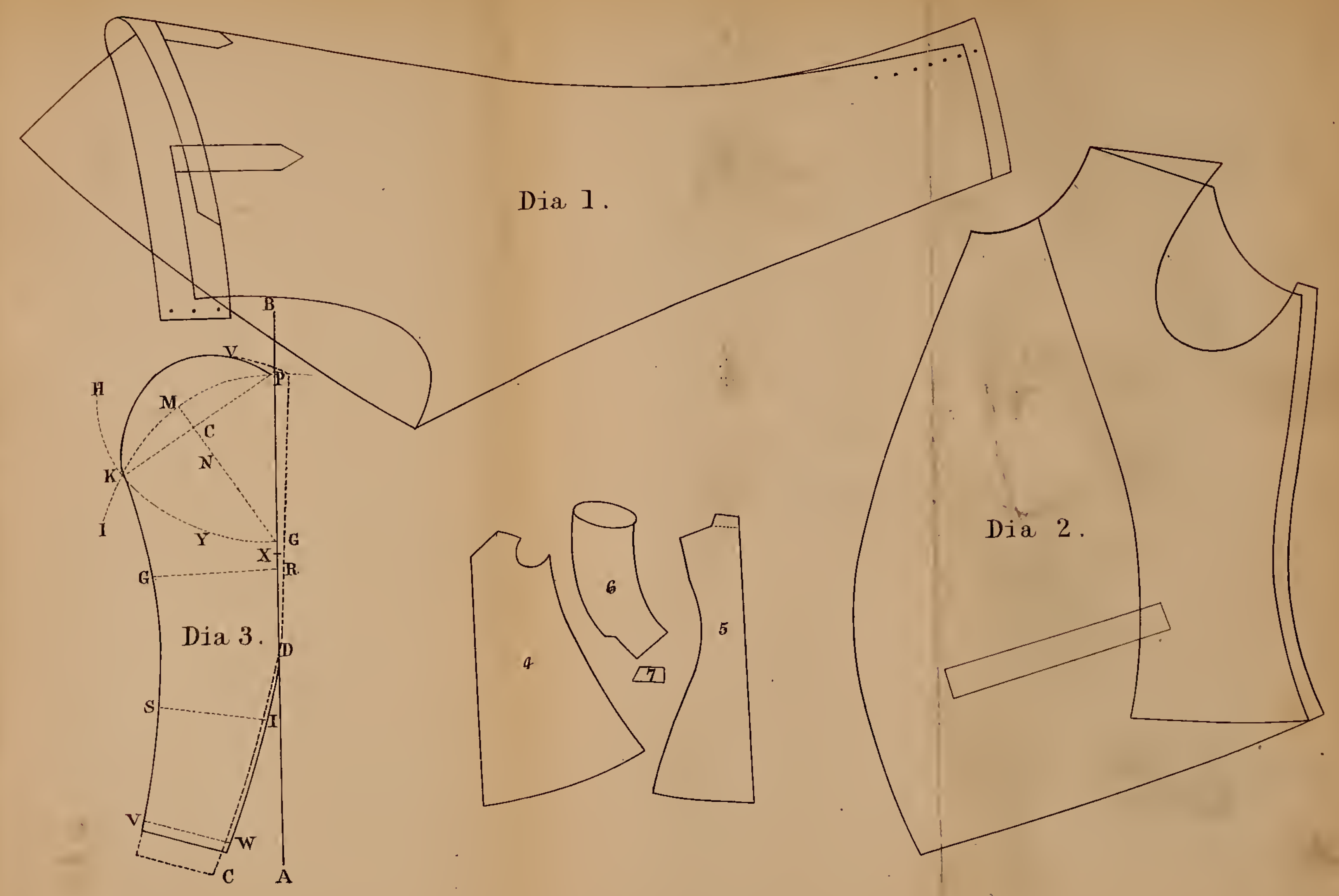



from the shoulder neck point, through the front of scye and side seam point, as the authors assert that it is an "indispensable certainty" in the cutting of a coat. I have seen an old tailor use this same line, and for the same purpose; but the scye should, according to his judgment, be half an inch in front of the line.

As such ample extracts from the Coat System have been given, it will suffice to add some examples of their instructions to construct Breeches and Vests, so that we may know positively the very deficient knowledge of the tailors of that period, as well as the primitive state of our art. The rules laid down are as meagre and insufficient as those given for drafting coats. These diagrams are absolutely without any lines of construction, so that the cutter's observation and capacity for imitating the models were his only resources. And as we know that tailors were not so well educated then as they are now, we can form some idea of the difficulty they had in copying outlines with a free hand. We will now give the authors' instructions.

\section{HOW TO MEASURE A GENTLEMAN FOR WORSTED STOCKING- BREECHES, RIBBED OR PLAIN, Dia. 1, Plate 3.}

"First, lay the end of your measure up at the hip-bone, and extend the measure down the thigh to the bottom of the cap of the knee, and as much lower as the rage of fashion may induce the party to require it.

"Secondly, measure the thigh very tight, and likewise measure tight the hollow part above the knee. Next measure the thick part, also tight as possible; then measure round the small part of the body for the length of the waistband, which is all that is necessary."

\section{OF CUTTING AND MAKING.}

"When at your cutting board and have your stocking-piece before you, observe the following maxim, which entirely results from the stretch or elasticity that there is in all framework of this nature, and requires that the breeches must be three inches longer than the measure. But for more particulars we refer you to the Plates.

"Lay your measure upon the piece within one inch and half of the top, then extend it to the intended place for the knee, and mark it and cut it longer an inch and a half below at the knee; then for the width, lay on the measure at the bottom of the knee, and mark for cutting one inch narrower than the measure upon the stuff in the double, and one inch less in gratation all the way up the thigh, and be sure to abide by the following example for the stride :-

"First make a deep fall down, and having laid your finger upon the measure at the bottom of the knee, with the other 
hand extend the measure to the fork, and make the stride within three inches of the length of the measure, this will give proper room for the elasticity of the materials, and ease and freedom to the wearer.

"Next cut your leg seam very straight, and not hollow as is the common practice, and let your side seams be likewise straight from the knee up to within four inches of the hip; and observe you put in a gusset piece from that place on the outside of the hip, two inches and a half wide at the top, and cut taper or bevelled down to a point five inches long both of the outside and inside.

"When thus done and your breeches are put on, you will find the ribs go straight down the thighs, which will avoid and provide against an abominable error in the trade, of twisting the ribs across the thighs, making them appear crooked, inwardly inclining, which seems to the spectator (according to the old vulgar adage) as if people were ill shap'd or knap knee'd. When you have got so far, cut your seat at the joining of the waistband, less by two inches double; and in making, let your knee-band be cut one inch longer than your measure, and back it on lining, and sew it in with the knee-band to the breeches; this will keep them to the full size at the bottom, and make them lie agreeably, and rise to the springing of the calf of the leg if required. Let both the knee-band and the waist-band be beared on according to your length of them (both) and not the breeches, which though diametrically opposite to the common practice in use, we do affirm is positively right, and the true justified and proved by long experience, and which will convince every practitioner on his first essay, if he does but adhere strictly to the rule."

Then follow directions how to make silk Frame breeches, black Florentine breeches, Kerseymere breeches, \&c., \&c.

\section{OF THE PRACTICE OF MEASURING AND CUTTING-OUT} Waistcoats, Dia. 2, Plate 3.

"First, having the person before you, lay on at the top of the shoulders and down as low before as the employer may wish to have the waistcoat. When this is done, put your measure round the body in three separate places, as over the breast, the belly and the hip. This will be all that is necessary touching the measurement.

"When you have your materials before you intending to cut out, please, before you begin to open the book to the Plate of waistcoats, observe well the figures, the modes, maxims, and turnings of the different parts, to facilitate the idea and appearance that those separations of things must bear before they are sewed or united together. This will greatly assist your notion 
when you lay on your measure to mark out for cutting your cloth upon the true scale; and please to mind that it does not appear too round before in the foreparts, and see that your neck is cut hollow, and at the gorget, spring it forward as the plate directs, upon which depends the chief art of fitting a waistcoat. Keep it very forward to lay close to the neck, or it will fall away from it-a most egregious error, if not guarded against, as above pointed out.

"There is another matter which requires thought, and that is in the length of the back to the forepart. Observe that the back must be of the same length as the Plate directs, and let the back lay on the foreparts straight and easy, and what you call closing the back to the forepart, take care that it answers the same, which will totally prevent the foreparts from driving up on the belly, which is a general complaint, mostly being caused by the back being cut too short, and the foreparts too round; both most flagrant errors, and should, to ensure success, be most strenuously guarded against: in order to do this properly, pay strict adherence to the delineations of the Plates; these possess all the faculties requisite for complete fitting, proved and certified by real experience as incontrovertible as demonstration itself. Therefore, the learner cannot pay too great a respect to the shape and manner of those sketches of drawings, to ripen and foster his faint ideas."

The concluding remarks of the authors form a fit ending to their work. Their self-satisfied tone is really amusing, and certainly on a par with their other performance. They say: "Having led our pupil thus far, we hope that he will be able to find his way without assistance. If his application is but adequate to the desire we have to serve him, he will, we make no doubt, cut a very brilliant figure in the trade, after he has had a little practice to justify our maxims."

Any method more simple or rudimentary than this one published by "A Society of Adepts" can scarcely be conceived. It was really the result of experience, and differed scarcely but in name from the plan of cutting by "rock of eye." It must be regarded as a proof that a desire or necessity was felt for some method by which tailors could draft their patterns from measures. In default of any other guide, this work may have been of some assistance to the cutters of that time; otherwise it is remarkable that the authors should have felt justified in publishing such a primitive method giving so little aid to students. Its issue could only be warranted by the non-existence of any other published method, and in those circumstances it was better than none at all. Although these authors do not state that this is the first work published on cutting in English, neither do they refer to any previous work on cutting, the only 
references I can find to the oldest English work are to this one; therefore I think I am justified in coming to the conclusion that it is our oldest work on the subject.

The coats of this period were of the simplest form, and without waist seams. The gallants could not have been so very exacting as to their form and fit, for the tailors had neither the means nor the knowledge to produce them. Richness of material or ornamentation was the great desideratum. The measures taken were of the rudest kind, they were few in number, and consisted of dimensions of the figure or garment, but they were of little aid in producing the principal points of the garments. Inch tape measures were either not invented or not used, for the ineasures were taken by and recorded on strips of brown paper or parchment, such as is practised by some shoe-makers and breeches-makers of the present day. The directions given by our authors, "after you have taken and marked all your measures, and set down his particular requests in your book of directions," show that the measures were preserved on these strips, but the particulars were to be inserted in a book kept for that purpose. This mode of procedure, combined with the imperfect method of cutting then in use, proves beyond dispute that our art was then in its infancy.

Perhaps we shall be better able to form some idea in our minds of the state of our trade at that period if we reflect for a moment on the trying position of the tailor, and endeavour to realize his feelings when about to cut a coat, we shall easily conceive the fear and trepidation with which he set about his task. Before him lies a piece of costly cloth the property of his customer. He has no system nor method to aid him; he is only possessed of a pattern for his guidance. The measures are few and imperfect; he has had little or no instruction, and his practice has been very limited; on his eye and judgment must he depend for success, and the result to him of success or failure is most important. Well may drops of sweat fall from his anxious brow, and doubts and fear harass his troubled mind. It reads more like a grim fact than a humorous joke, the anecdote of a German tailor's wife who said to her children when putting them to bed, "My dears! now pray for your father, for he has a coat to cut." His wife no doubt shared his anxiety, appreciated his difficulty, and sympathised with her husband in his anxious task, and hence desired that Heaven should lighten his labours.

Before this time cutting by patterns was the general practice, and it appears that blue coloured paper was specially used for this purpose, a usage which prevails amongst the French tailors at the present time. A tale is told which, whether true or not, will exemplify the condition of the tailor's knowledge at 
that time. It is said that a gentleman complained that his coat did not fit him, when the tailor replied, "he could not understand it as he had cut it by his "blue pattern." Happy was the tailor who possessed a good-fitting pattern; it was cherished by him as a valuable trade secret. In indentures it was sometimes stipulated that the master should give a copy to his apprentice, but this was done only on condition of strict secrecy. So valuable were these patterns considered that they were often bequeathed as a fitting legacy from father to son. It was probably from the high estimation and great value attributed to these patterns that tailors gave them, facetiously though irreverently, the name of "Gods," a term by which any supposed highly-valued patterns are known at the present day.

Tailors soon found that the most difficult part to draft was the scye. They saw that a horse-shoe possessed a similarity of shape to a good fitting arm-hole; so to form them they used various sized horse-shoes, according to the size of arm-hole required. Tradition also tells us that another and still more simple practice prevailed in order to obtain the same result, viz., to draft a good scye. The left hand was placed on the cloth, and the fingers and thumb spread out so as to form nearly a circle; they were then traced round by chalk and the scye formed.

We have now arrived at a starting point for our studies, one from which we can view with advantage the rise and progress of our Art. Simple and inefficient as the method propounded. by the Society of Adepts was, we must yet give them every credit which belongs to those who first endeavour to enlighten a trade. If this work did not possess great talent, it certainly had this merit: it was the first, as far as at present can be ascertained, and no doubt their example stimulated other and. later writers to publish their productions, which recorded the accumulated and advanced knowledge of their day.

A work on the subject of tailoring may be most appropriately noticed here, as it is the earliest one on the subject I have seen in English, although it does not refer directly to the art of cutting. Still, as it was published nine years preceding that by the Society of Adepts, it probably indicates accurately the state of our trade at that period. It is called "A sure Gruide against Waste in Dress; or, the Man's Mercer and Tailor's Assistant, shewing the exact quantity of cloth, \&c., necessary to make any garment, from a child to a full-sized man. By M. Cook, Tailor, 1787."

Its purpose is very simple, and is perhaps best explained in the author's own words: "The inconvenience to which the tailor is frequently exposed from a mistake in the calculation (of the quantity of cloth required), the author flatters himself will be 
hereby rectified; and while the customer incurs no unnecessary expense in purchasing more than is needful, the tailor will avoid the trouble of piecing in an unbecoming manner." This book contains elaborate tables giving the quantity of cloth, according to the width, which would be required for making various garments of different sizes. The most interesting fact which it conveys to my mind is, that it was the general practice of customers to purchase their cloth, which tailors had to make up. In confirmation of this idea the author says, in his introductory remarks : "Masters of academies, captains of the navy and army, wishing to have their or their children's clothes made to fit with ease, elegance, and taste, may have a suit or any garment made at six hours notice by sending their cloth," \&c.

No instructions whatever are given how to cut garments. It would seem as if methods of cutting were not yet published, judging from the fact, that the work by the Society of Adepts, published nine years later, contained, as we have seen, the meagrest information possible on the art of cutting.

Another fact tends to the conclusion that this book clearly shows the state of our trade knowledge, viz.: that our oldest trade works in Spanish and French also only give instructions how to cut from the cloth the various garments.

Mr. Golding also acknowledges his indebtedness to a Mr. Cook in the compilation of the first edition of his work, and this is, I presume, the identical Mr. Cook, the author of this work.

In the first quarter of the nineteenth century there was quite a concourse of authors and inventors of systems. If, as we have seen, there had been little or no method in cutting, our trade had determined to make amends for its inactivity or sloth. A variety of names come before us claiming notice and jostling for precedence. This awakening of our trade ushered in a new era of progress. Let us hope that the impulse which these worthy men gave to the study and teaching of method in our art has not yet ceased, and will continue until our trade shall have reached the highest development to which cultivated experience, combined with artistic and scientific knowledge, can elevate it. It is difficult to determine who has the first claim on our attention as the next old writer-Hearn, Golding, Wyatt, Minister, Hadfield, and others, seem all to have been studying and producing small works or pamphlets within five years of each other. The difficulty in determining the right of precedence is increased by the fact that dates were as a rule omitted from the books.

The mental activity of our trade was not confined to writers, for besides these there were several gentlemen daily engaged as 
teachers of cutting, who did not publish any systems, but who yet have left traditions of their merits. Among these were the names of McAra, Norris, and Dietrichstein. The last of these gentlemen issued a number of patterns from his establishment in Rathbone Place, which were sold in all parts of England. It appears to have been the custom of country master tailors to come each year up to London to observe and get the newest fashions. Supplied with a few patterns, they were provided with all that was obtainable for the successful carrying on of their business.

According to a copy of one of Mr. Dietrichstein's circulars, tailors had to pay a heavy price for his patterns. A complete set of useful paper models was charged five pounds; men's frock or lapelled coats with new or old backs, 5s. 6d.; a lad's Hussar suit, 7s.; men's breeches or pantaloons, 3s. ; waistcoats, $2 \mathrm{~s}$.; square, $4 \mathrm{~s}$. $6 \mathrm{~d}$.; compasses, $6 \mathrm{~s}$; inch measure, $2 \mathrm{~s} .6 \mathrm{~d}$. These extracts show that the pattern trade must have been a very profitable one at that time.

Between the period of the production of the work of the Society of Adepts in 1796 and Mr. Hearn's works, there must have been other authors, or at least teachers of cutting who had not published works, but who yet must have had considerable influence in promoting a knowledge of and advancing the science of cutting. The only trace I have been able to find of them is in an extract from a scurrilous publication, called "Gaffney's Tailors' Irish Instructor," credibly attributed to Mr. Dietrichstein, of Rathbone Place. He says : "Amongst the numerous pretenders professing themselves competent to teach the art of cutting may be enumerated Snell, Kaye, Fenton, Sawyer, Ivymy, Morrice, Jones, McCarra, Wyatt, Herring, Howlett, Pickering, Bayley, Goulding, Hearn, and many others." As I know that several of these gentlemen were authors and teachers of cutting, we may give, I think, sufficient credence to Mr. Dietrichstein as to conclude that they were teachers of cutting. He refers to Mr. Mark Cook's tables published in 1787, but the work of Mr. Cook on cutting I have not yet been able to find, although I know he was a contemporary of Mr. Hearn's, and that he published a work or works on the subject. He also states that, "It was my intention to have gone at some length into criticisms on numerous of the London masters' style of cutting, particularly Vernon, Frolich, Miller, Paul, Gibson, Lambert, Barber, Franck, Solomon, Bower, Wettig, White, Middleton, Cox, Watkins, Radford, Cartwright, Otley, Fisher, Hawkins, Jaretz, Niel, Fox, Bachner, Levick, Pollards, Davis, Steel, Clark, Stulz, Weston, Allen \& Wilson, Davidson \& Schwertzer, Stewart, Jacks, Smith, Croft, Baker, Milne, Wright, Clark, Louis Bazal- 
gette, Shampeter, Stuart, Thewall \& Conol,"-quite an array of old London master tailors. It may surprise some, as it has me, to see the names of some masters of the present day amongst this list, and of others of similar names, but who probably have no family connection.

The most voluminous, as well as one of the oldest and ablest, of our trade authors was Mr. Hearn. His writings deserve our best attention, for they extend over a period of time, and show that his mind was progressive. As we proceed we shall discover that we are indebted to his labours for several measures which are used by the trade generally. His works are, however, disfigured by long and diffuse criticisms of a personal character, and of an acrimonious kind, which greatly tend to lessen their value, and certainly lowers the estimate of the writer in later unprejudiced readers' minds. I have before me one of $\mathrm{Mr}$. Hearn's works, with the date of 1818 ; but I have some others without date which were published previously. I am favoured with the opinion of our oldest living author, the venerable Mr. Minister, sen., probably the only person living who has a personal knowledge of the subject, and he emphatically states, "That he would award the palm of merit of being the first author of 'A System of Cutting' to Mr. Hearn."

It is difficult to determine to whom we should give the honour of being the first writer after the Society of Adepts in 1796. This arises partly from the fact that most of the works on cutting at that period were published without any date being affixed to them, and, also, probably as Mr. Hearn in the Preface to his "Rudiments of Cutting" says, "All other works of the kind published in modern times are so brief and mysterious, that it is almost impossible for any person (if his intellect be ever so good) to gain but little information from them." In his Introduction he says, "I believe the first thing that has been published for a number of years (but which has not been many months in circulation) is a table, called 'Reed's Proportionate Table." "This can scarcely be called a system of cutting, for, as Mr. Hearn says, "it has not the smallest tendency to forming a coat; it merely gives the width of the back, the size round the arm-hole, \&c." Still, the fact is interesting to us, as showing the paucity of knowledge of cutting by the trade for such a table to be published, and at the price of $6 \mathrm{~s}$.

A table of a similar character was also published by Mr. Dietrichstein, of Rathbone Place. We are also informed that Mr. Cook published his "Principles of Cutting Coats." This is the same Mr. Cook, I presume, who published "A Sure Guide against Waste in Dress," in 1787. Our author says, "This work has a greater resemblance to science than those of 
Reed or Dietrichstein, because it is the only one I have had the pleasure of examining which gives us any instructions to form the points of the back, forepart, and sleeves of a coat."

The use of the inch tape is now so universal, and its advantages so evident, that we can scarcely conceive it possible that it was not in general use at the beginning of this century, and that it was necessary to explain and advocate its employment. Two facts, however, prove it to have been necessary, for $\mathrm{Mr}$. Hearn, in his "Section on Measuring," says, "The use of the inch measure having become so prevalent, it seems unnecessary for me to point out its superiority. It may appear difficult on the first inspection to those who have not been accustomed to the use of it, but I am persuaded that if they would only take the trouble to practice two or three times by measuring a coat instead of a customer, and write the figures down according to the following instructions, they would find it more expeditious, convenient, and correct, than the contemptible mode of using slips of parchment." The italics are mine, as I wished especially to note the fact that slips of parchment were in use at this time. Who it was that first introduced inch measures, there are no facts at present to prove; but from an advertisement by Mr. Hearn, we find that he issued them. It runs as follows: "Recently published, at cost price (3s.), the Second Edition of Hearn's 'Rudiments of Cutting, with an easy Guide to the use of the Tape Inch Measure.' N.B.-As it is essential for the painted Tape Inch Measure to accompany the Rudiments (the price of which is $2 \mathrm{~s}$.) it will be advisable, if ordering of a Country Bookseller, not to omit ordering the Measure, as it may be difficult to procure one in the country."

After some very prolix instructions how to take the ordinary measures of a coat, Mr. Hearn proceeds to direct the student how to measure for to ascertain the degree of height or lowness of neck. He says :-

"Suppose the person to have a very short or very long neck, or if fancy requires the neck of the coat to deviate from the proportionate height, I should recommend the height of the neck to be taken : viz., by placing the end of the measure to the top of the back seam, or to the place where the top is required to be, and extend it in an oblique direction to the place where you intend the middle of the back scie to be. But to take this measure scientifically, place the end of the measure at that part of the back seam which is in a straight line with the hind seam of the sleeve, and extend it in that direction, and make a mark or dot with a piece of chalk, one eighth of the whole of the breast measure from the back seam. The breast measure being 36 inches, the eighth of which is $4 \frac{1}{2}$ inches, which is equal to one-fourth of half the breast measure 
(which is the proportionate width of the back); then take the height of the neck from where you intend the top of the back seam to be, to the dot or mark, which height would be 7 inches, if required of a proportionate height, as represented in the model ; if not, it would vary accordingly."

Those tailors who take an interest in the development of our art, will view with surprise this record of the early introduction. of this cross measure for the purpose of ascertaining the true height of neck. Many cutters use this measure at the present day, and it is often spoken of as if it was a novelty or quite a modern discovery. As we proceed we shall find that we are further indebted to $\mathrm{Mr}$. Hearn, and that to his intelligence and unwearied industry a debt of gratitude is due, which has yet to be paid.

\section{SECTION II.}

"Directions to form the Back according to the Model. (Plate 4, Dia. 1).-In the first place, lay your cloth smooth, with the list edges from you; place 39 at the bottom of the double edge of the cloth to your left hand at $A$, extend the measure up the edge to 19 , and make a mark at $B$, which is for the length of the waist, and continue the measure to 16 , and make a mark at $\mathrm{E}$, which is for the height of the small or hollow in the waist; continue the measure to the end, and make a mark also; then draw a line at the mark made for the length of the waist in the direction of $\mathrm{B}$ and $\mathrm{E}$; then draw another line across at $\mathrm{E}$, for the height of the small in the waist, likewise one at top in the direction of $\mathrm{D}$ and $\mathrm{F}$ (but this line should not be drawn in a square direction, but rather higher at $\mathrm{F}$ than it is at $\mathrm{D}$ ). This being done, make a mark at one inch from the edge of the cloth, on the line drawn to form the hip upon at $J$, which is for the bottom of the back seam; then draw a straight line from the mark at $J$, to the edge of the cloth at the top at $D$, which forms the back seam; then make a mark six inches or one-third from $D$, the top of the back seam, at G : then fix your measure fast with your right hand, making $\mathrm{D}$ or the top of the back seam as if it was a pivot, and cast a circular line with your left hand, from $\mathrm{G}$ in the direction of $\mathrm{H}$; find $4 \frac{1}{2}$ inches on your inch measure, and place it on the line drawn for the back seam at I, making the end of the measure terminate on the circular line at $\mathrm{K}$; but the measure must be placed in a straight direction (see the dotted line from $\mathbf{I}$ to $\mathbf{K}$ ). Having made a mark at $\mathrm{K}$, which is for the point of the top of the back scie, then mark the same width as from $\mathrm{C}$ to $\mathbf{M}$; then draw a line from $\mathrm{K}$ to $\mathrm{M}$; then mark the length of the back scie half one-third from $\mathrm{K}$ at $\mathrm{N}$, on the line $\mathrm{KM}$; then make a mark at the top of the back, half one-fourth from $\mathrm{D}$ at $\mathrm{O}$; then make a mark for the width of the back at the hip at $\mathrm{P}$, which should be rather less 
Plate 4.

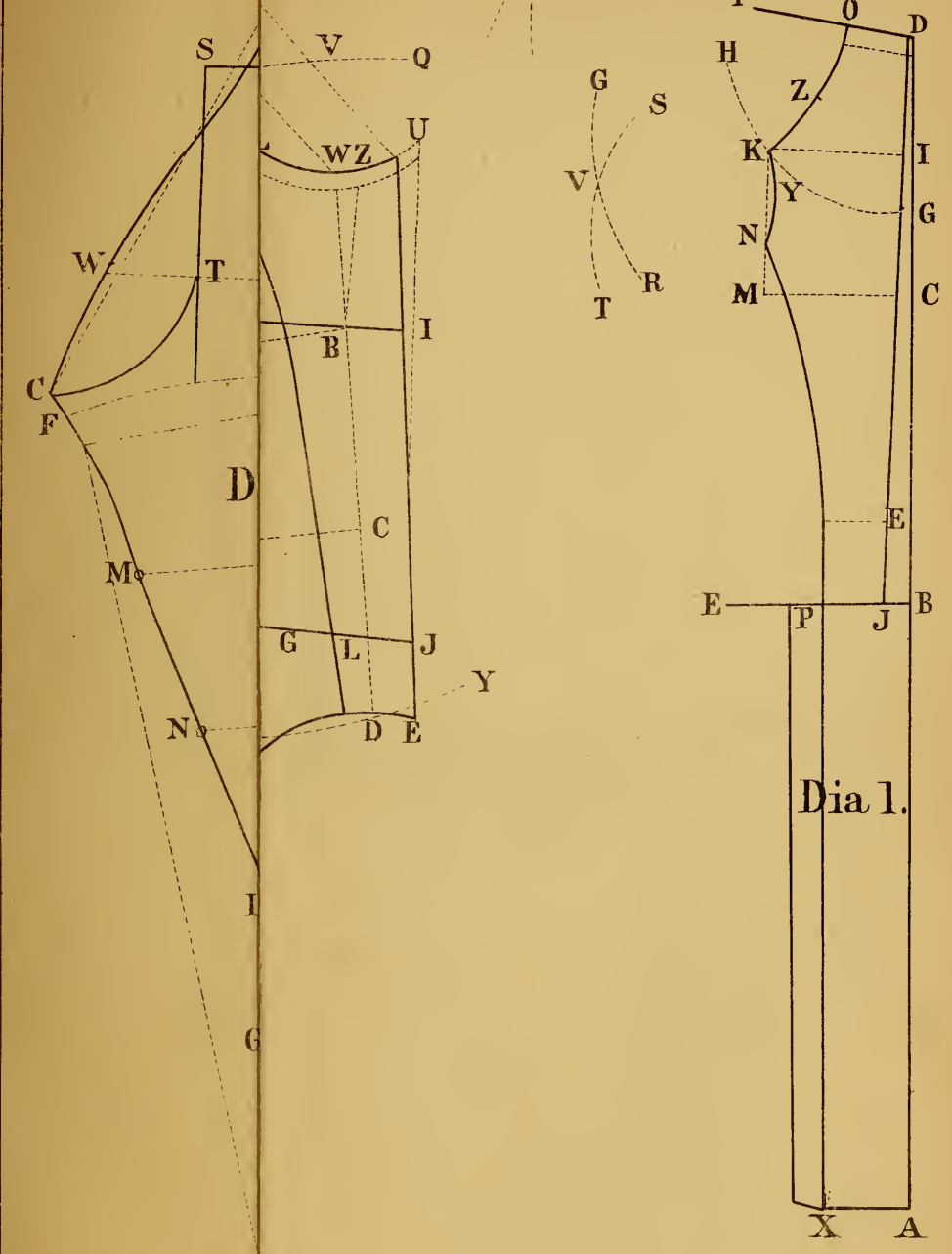





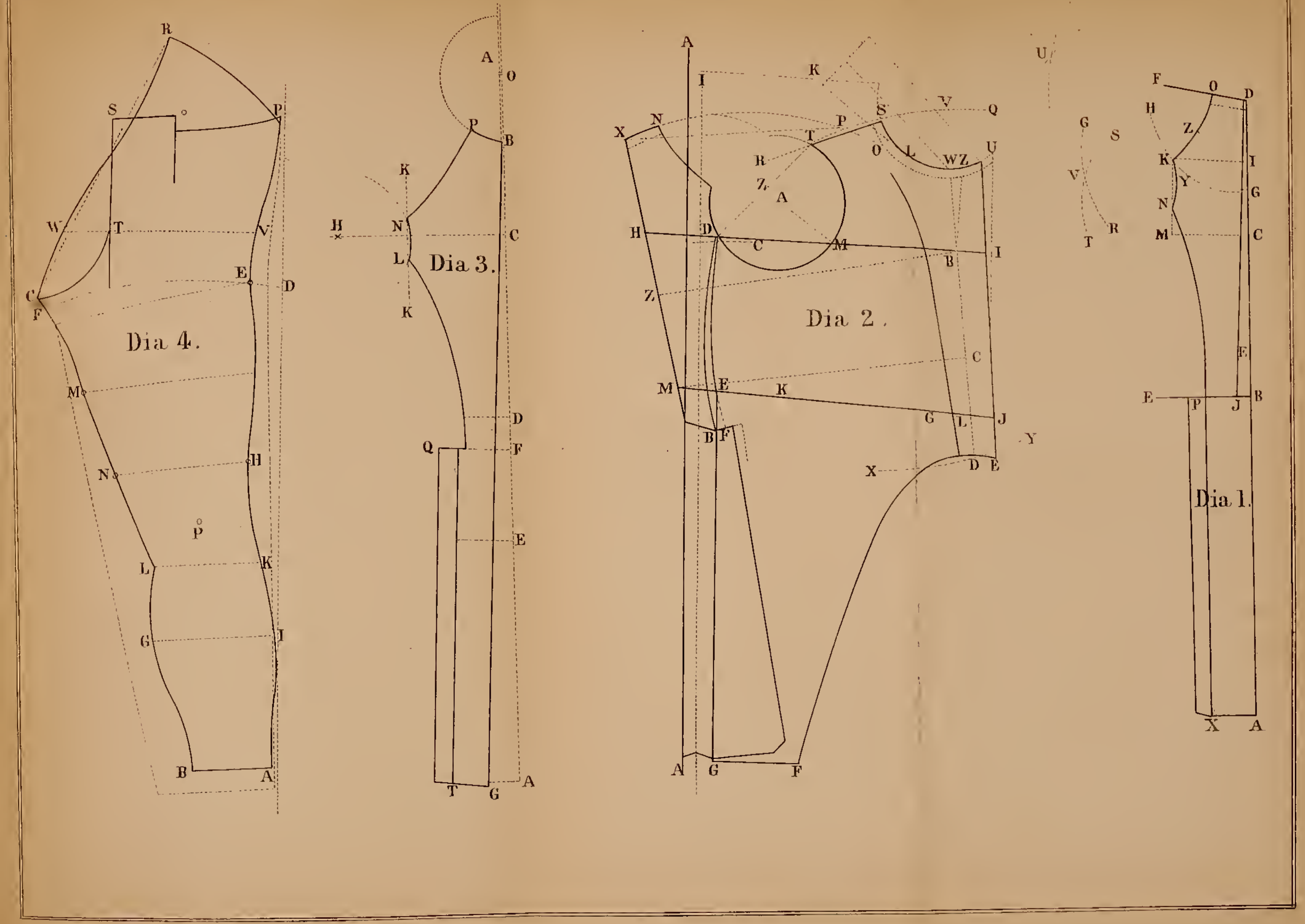



than half the fourth. This being done, take twice the length of the back scie from $K$ to $N$, which is 6 inches, and cast the back scie as follows : first make $K$ your pivot, and cast a small portion of a circle, by 6 inches or twice the length of back scie, as from $R$ to $G$; likewise make the point at $N$ your pivot, and cast another small portion of a circle by 6 inches, as from $T$ to $\mathrm{S}$; then make the cross at $\mathrm{V}$ your pivot, and cast a portion of a circle as from $K$ to $\mathrm{N}$, which forms the back scie; likewise, take twice the length or distance from $\mathrm{N}$ to $\mathrm{P}$, at the bottom of the side seam, which is 25 inches, and make your pivot at 25 inches distance from $\mathrm{N}$ and $\mathrm{P}$, which must be done by casting a small portion of circles, the same as was done in casting the back scie. Cast the side seam by making your pivot at the intersection of the circles; the shoulder seam is formed in the same manner as the side seam and scie, by making your pivot at the intersection of the circles at $\mathrm{U}$; then draw the line from $\mathrm{P}$ to $\mathrm{X}$ to form the skirt. The back being thus far completed, supposing the neck of the coat is required lower than the proportionate height, say half an inch, in that case mark off half an inch at the top of the back-see the dotted line across the top of the back in the model. Make a mark in the centre of the shoulder seam from the standard height (see the mark at $\mathrm{Z}$ in the model), then cut the back."

\section{SECTION III.}

"Directions to form the Forepart according to the Model. (Plate 4, Dia. 2).-The forepart is undoubtedly the principal part of the coat, consequently the most difficult to form, but by a little attention to the following principles, no person can fail in attaining the rudiments. First, suppose the line with an $\mathbf{A}$ at each end to be the list edge of the cloth made straight, then place the bottom of the back skirt at the bottom of the cloth on the line A, and let your back lay smooth from thence to the hip at $B$, and make a mark for the height of the hip; then mark the distance at $B$, from the line $A$, where the bottom of the side seam is to be, which distance should always be the same as the width of the back at the hip. Having marked the distance the hip is to be cut in at $B$, then place the bottom of the back side seam at the mark at $B$, and keep the edge of the back seam exactly on the line A, or edge of the cloth, from the hip to the top of the back seam; and while laying in that position, make a mark at the point or top of the side seam of the back on the cloth at $\mathrm{C}$, which is the width of the back from the line or edge proceeded from; then make B your pivot, and cast a circular line from the mark at $C$ to the edge or line proceeded from, which is $4 \frac{1}{2}$ inches, or width of the back. Then make a mark one-third of the width of the back, or $4 \frac{1}{2}$ inches 
from the line $\mathrm{A}$ on the circular line at $\mathrm{D}$, which is one inch and a half, or one-twelfth of the breast measure, the distance the top of the forepart side seam nuust be from the line A. Having found the top and bottom of the side seam, place the back in a closing position from $\mathrm{D}$ to the small of the waist at $\mathrm{E}$.

"But to proceed with what may be termed a proportionable made waist, which may be called 19 inches for a man of a medium size and height; therefore, the back being in a closing position at the point $\mathrm{D}$, let the back lay perfectly smooth, so that the bottom of the side seam of the back lap over the mark made for the bottom of the side seam of the forepart at $B$, about half an inch-(see the dotted appearance of the back from $\mathrm{E}$ to $\mathrm{F}$, which represents the lap-over or spring required). The back being in that position, mark the side seam of the forepart by the curve edge of the back down to the mark, as at $\mathrm{M}$; then reverse the back, and lay the hip of the back on the mark made for the hip of the forepart, as if being closed; extend the back to $\mathrm{E}$ in the small of the waist, and mark the remainder of the side seam by the curve edge of the bottom of the back side seam, from $\mathrm{E}$ to $\mathrm{B}$, which completes the side seam of the forepart. Then draw a line from $B$ to the bottom of the skirt at $G$. Then place the back in a closing position, by placing the top of the side seam of the back to the top of the side seam of the forepart, likewise the bottom of the side seam of the back to the bottom of the side seam of the forepart; those four points being placed together, let the back lay perfectly smooth: viz., the side seam to appear closed at the top and at the bottom, but open at the small of the waist, at $\mathrm{E}$ (see the Model). Draw a line from the end of the circular line or third in the back seam, from $H$ to the point of the top of the back side seam at $\mathrm{D}$, continuing it right across the forepart to I; then draw the line from the mark made on the back, $\mathrm{M}$ to $\mathrm{J}$; the front of lappel, which should be of equal distance at each end from the upper line; keep the back in the same position, and place the end of your measure to the edge of the back in the small of the waist, at $M$, and continue it on the line, and make a mark at the one-third on the line at $\mathrm{K}$, continuing the measure to the size of the breast, and make a mark also on the line that distance from $\mathrm{M}$ at $\mathrm{L}$, which is 18 inches; then make a mark on the upper line two-thirds (12), from $\mathrm{H}$ in the back seam at M, which is for the front of the arm-hole, allowing what is sufficient for the sewing of the back and side seam.

"Keep the back still in the same position, and make the mark at the third in the waist at $K$, your pivot, and cast the circular line from $\mathrm{N}$, the top of the back shoulder seam, to $\mathrm{O}$, which should invariably be cast from the standard height, whether 
the back is required higher or lower in the neck. Having cast the circular line from $\mathrm{N}$ to $\mathrm{O}$, the back still remaining in the same position, then place the end of your measure fast at the top of the standard height of the back seam at $\mathrm{X}$, and bring your measure forward in a straight line until $13 \frac{1}{2}$, three-fourths, terminates on the circular line at $\mathrm{P}$ - (see the dotted line drawn from $\mathrm{X}$ to $\mathrm{P}$ in the model). Having made a mark at $\mathrm{P}$, make the mark at $\mathrm{L}$ your pivot, and cast the circular line from $\mathrm{P}$ to $\mathrm{Q}$, and from $\mathrm{P}$ to $\mathrm{R}$, then place the mark $\mathrm{Z}$ in the centre of the back shoulder seam on the mark at $P$, where the two circular lines cross, and extend the back on the line, and make a mark at $\mathrm{S}$ for the shoulder point; then mark the length of the forepart shoulder seam from $\mathrm{S}$ at $\mathrm{T}$, draw a straight line from $\mathrm{S}$ to $\mathrm{T}$, which forms the shoulder seam, then make a mark one-fourth from $\mathrm{S}$ the shoulder point, on the circular line at $\mathrm{V}$; then make $\mathrm{V}$ your pivot, and cast a circular line from $\mathrm{S}$ the shoulder point, to $U$ the point of the lappel, which forms the neck or gorge, and make the size of the neck from the standard height in the back seam to the front of the collar at $W$, half the size of the breast, 9 inches; make the top of the back seam your pivot, and cast the circular line from $\mathrm{X}$ to $\mathrm{Y}$ by the length of the lappel, which is 25 inches. Draw a line from $\mathrm{D}$, the top of the side seam of the forepart to $T$ the point of the shoulder seam, and find the centre of that line at $\mathrm{Z}$, and draw a line from $\mathrm{Z}$ to the mark made on the line for the front of the armhole at $\mathrm{M}$, then make a mark on that line one-fourth from $\mathrm{Z}$ at A, which should be in the centre of the points D T and $\mathrm{M}$; then make the mark at $\mathrm{A}$ your pivot, and cast the lower part of the scie with your left hand from $\mathrm{D}$ to $\mathrm{M}$; likewise make $\mathrm{A}$ your pivot, and cast the upper part of the scie or armhole with your right hand from $\mathrm{T}$ to $\mathrm{M}$, which gives the true form of the armhole, and forms an exact ring; then take the sizes of the body, first the breast, by placing the end of your measure at the edge of the back seam, and bring it forward in a straight direction, making the size of the breast terminate on the line $\mathrm{H} \mathrm{M}$ at $\mathrm{B}$ (see the dotted line in the model from $\mathrm{Z}$ in the back seam to $B$ the size in front).

"But the sizes of the body should always be marked one inch larger than the real size of the measure, which inch is allowed for seams, \&c. Having made a mark at B for the size of the breast, then take the size of the belly from the small at the waist at M, to the centre between the length of the lappel, and the size of the breast at $\mathrm{C}$. Having made a mark at $\mathrm{C}$, and one for the rise round the hips at $D$ on the circular line cast for the length of the lappel, then mark the front edge of the lappel at such a distance as may suit your own taste, or that of your customer. Having marked the front edge, then form 
the bottom of the lappel, which should be square as far as the buttons stand in, or it will cause a defect when the coat is buttoned, and as to the form or width of the skirt, that must be regulated as fancy may direct. Having formed the skirt, then mark where the buttons are to stand, making the size the exact centre between the front edge, and the mark where the buttons are intended to stand."

\section{SECTION IV.}

"Directions to form the Sleeve according to the Model. (Dia. 3. Plate 3.)-First, draw a line the whole length of the sleeve, as from $\mathrm{A}$ to $\mathrm{B}$, then make a mark one-fourth from the line proceeded from at $\mathrm{C}$; place 33 on the mark made at $\mathrm{C}$, and extend the measure in a slanting direction, until 20 touches the line proceeded from; make a mark at $\mathrm{D}$, and continue the measure up the line, and make a mark $4 \frac{1}{2}$ inches for the top of the hind seam, which $4 \frac{1}{2}$ inches is deducted from the full length of the sleeve for the width of the back; then draw a straight line from $\mathrm{D}$ to $\mathrm{C}$ (see the dotted line from $\mathrm{D}$ to $\mathrm{C}$ in the model), then add the round for the full of the arm from $\mathrm{D}$ to $\mathrm{C}$; this being done, place the back and the forepart in a closing position at the armhole, and measure all round at the edge of the armhole. Having taken the exact size, double that size on your inch measure, and place the double end of your measure at the mark made for the top of the hind seam, and make a mark at the single end, which will be half the size of the armhole at $\mathrm{X}$; but as the top of the sleeve should always be formed the exact size of the armhole, there should be about one inch deducted from the mark at $\mathrm{X}$, which is half the size of the armhole, therefore make a mark at $G$, one inch from the mark at $\mathrm{X}$, which will be one inch less than half the size of the armhole; this being done, make the mark for the top of the hind seam your pivot, and cast the circular line with your left hand from $\mathrm{G}$ to $\mathrm{H}$; then make $\mathrm{G}$ your pivot, and cast the circular line from hind arm point to I with your right hand; draw a straight line from the point where the circular lines cross at $K$ to point of hind arm, then make a mark in the centre of that line at $\mathrm{C}$, then draw a straight line from the point at $G$ to the mark at $C$, continuing it to the circular line at $\mathrm{M}$; then make a mark on that line one-third of its length, from $\mathrm{M}$ to $\mathrm{N}$, then make the mark at $\mathrm{N}$ your pivot, which is of equal distance from the top of the fore and hind arm seams, and cast a circular line with your right hand from $\mathbf{K}$, the point where the circular lines cross to hind arm point, which gives the true form of the top of the sleeve. Having thus formed the top of the sleeve, before you proceed any further, be convinced that you have formed it the exact size of the armhole, by measuring round the edge of the top of 
the outside sleeve, likewise across to $K$, in the direction of the shape of the inside; and if you find it accord with the armhole, then proceed to take the sizes of the sleeve; but if fulness is required in putting in the sleeve, as it generally is, it must be added after the top of the sleeve is formed; if not, your points of the top of the sleeve will not keep their proper places; consequently, the sleeve will set very uncomfortable to the wearer, as well as disgraceful to the cutter.

"Next draw a line from the elbow to the top of the sleeve, as far from the top of the hind seam of the sleeve as you may require for fulness-say one inch (see the dotted line drawn from the elbow to $\mathrm{P}$ in the model). Then make the elbow your pivot, and cast a portion of a circle from the point, which is the top of the hind seam of the sleeve; make your. pivot on the lower circular line, as far from $G$ as will be a centre between the top of the round of the outside sleeve at $Y$ and $\mathrm{P}$, where the circular line crosses the line drawn from the elbow, and cast a circular line with your right hand from $\mathrm{V}$ at the top of the sleeve to $\mathrm{P}$ (see the dotted line from $\mathrm{V}$ to $\mathrm{P}$ ), and this gives the fulness required; then mark the size of the sleeve, as from $R$ to $G$, and from $I$ to $S$, and from $W$ to $V$, and shape the fore seam accordingly; likewise draw a line from $C$ to form the bottom, and draw another line as much above the length as you may deem necessary, to be added by the cuff.

"In cutting the inside sleeve, let the first line drawn from the elbow to the hind arm point be your guide for the size, and that which is added for fulness be locked in from the elbow to the top, which will cause the top point at $\mathrm{P}$ to be exactly the hind arm point, and, if you wish to lay the sleeve in, lay it in at the fore seam. In respect to hollowing the inside sleeve under the arm, cut the inside to run regularly with the outside, at both fore and hind seams.

"I have thus given a minute definition of the delineation of a coat, upon my standard system, which is applicable to regular and proportionable shapes; but as the form of the human shape is so various, it would not only be tedious to lay down rules for every particular case, but also ridiculous to attempt it."

Between the first system published by Mr. Hearn, and the last one issued by him, there exists a considerable difference. The earliest one, one of the first published in England, and most probably the first, was founded on proportions of the breast measure; many of them complex in their operation, uncertain in their relation, and unsatisfactory in result. Mr. Hearn was not slow to discover that proportional systems are only suitable to proportionate figures. He insisted over and over again that the make of the customers must be provided for by measurement or observation. 
The system which he published in a fifth edition in 1823 is a direct measurement system, so that a peculiar interest attaches to it, as Mr. Hearn may justly claim to be the pioneer of direct measurement systems in this country, this being undoubtedly the first system of the kind published here. In France, it is true, measurement systems had been published, but these were complex though logical, every point of any importance being measured; Mr. Hearn's system is, however, eminently simple and practicable, the evident emanation of an Englishman's mind. It is questionable indeed whether our author had ever heard of those French authors, or that he could have read or understood them if he had seen them. Following his teachings, they bear upon them the impress of his own inventive genius, and convince me that his systems were the result of most patient thought and careful experiment. "I am convinced," said he, "there can be no certainty in the fit of coats without taking the make of the person, and further on I flatter myself the following measure will be found, if taken correctly, the most valuable thing ever offered to the trade. It will completely confute all proportions taken from the size of the breast, for it will be clearly proved that the proportions of the breast have nothing to do with finding the various points of a coat. It has been from my excessive experiments that I have at last ascertained dimensions for every essential point necessary for tailors to fit the human form. The most modern cutters amongst us have divided the breast measure into equal proportions of different magnitudes, as a guide for fitting the various parts of the body. I have experienced the fallacy of those proportions for many years, and little did I expect a better and more correct plan would be discovered when I published the fourth edition, although my mind was incessantly at work, so much so that those studies have been my principal element (occupation) the greatest part of my life." It will be curious to note that at this time (1823) the inch tape measure was not yet universally used. The system is introduced by full instructions to measure. He says: "On Measuring, \& c.-As the art of measuring necessarily precedes that of cutting, I shall commence with my instructions on that head. The use of the tape inch measure having become so prevalent, it seems unnecessary for me to point out its superiority. It may appear difficult, on the first inspection, to those who have not been accustomed to the use of it; but I am persuaded that, if they would take only the trouble to practise two or three times by measuring a coat or a bust, instead of a customer, and write the figures down according to the following instructions, they would find it more expeditious, convenient, and correct, than the contemptible mode of using slips of parchment. I have spared no 
pains to simplify the method, so that those who have not been accustomed to measuring, cannot fail in accomplishing the art with the greatest ease; and as there cannot be any certainty in the fit of a coat if the measure is taken incorrect, or without ascertaining the natural gait or standing position of the person, whether upright or stooping, hollow backed, or round shouldered, \&c.; and if they possess any of the above irregular positions, insert them with the other particulars that may be directed by the customer. Attention to the above observations will not only assist your memory, but will enable you to make the necessary allowances for all irregular positions when you are going to cut.

"In taking the measure of a person for a coat, I would recommend the student to take it as follows:-

"In the first place, request the person to button his coat from top to bottom, in order that you may have a fair view of his form and position, and place his arm in the form of a square; the arm being in that position, suppose the hind seam of the sleeve to be a line drawn from the elbow to the back seam, which is in the centre of the back, which line should be on the square with the back seam, so as to cross the centre of the back scye. I merely represent it by supposition; I do not say it is absolutely necessary to draw a line, for when the arm is placed on the square with the back seam, it is readily perceived where a line would come to, supposing it were to be drawn up the middle of the arm, as from the elbow to the centre of the back. You having made the above observations, then place the end of your tape inch measure at the top of the back seam; but as fancy frequently requires the height of the coat very high or very low, the proper place in that case is to place the end of the measure at the socket of the neck, or top of the back-bone or spine, which will produce the neck of the coat of a medium height; and if fancy requires it high or low, it should always be altered after the back and forepart are marked out. You having placed the end of your measure as above described, extend it down the middle of the back to the supposed line which runs from the elbow to the centre of the back; suppose it to be $5 \frac{1}{2}$ inches, and make a dot or mark with a piece of chalk or pencil, then take the bounds of the armhole under the arm, which should be taken about half way under the arm, suppose it to be $12 \frac{1}{2}$ inches.

"In the next place, I shall observe the necessity of taking the height of the armhole, which has heretofore been generally found by a proportion of the breast, or by the observation of the eye; a proportion of the breast may do in some instances, but there are great exceptions, and it may be ascertained by measurement, by placing the measure at the top of back seam 
the same as when taking the height of the neck, bringing it down to the bottom of the armhole. You having written down $5 \frac{1}{2}$ for the height of the neck, and $12 \frac{1}{2}$ for the bottom of the armhole, then place the end of your measure at the top of the spine, and extend it down as far as the hollowest or smallest part of the waist, for the purpose of ascertaining the exact height or situation of the most hollow part of the waist, which is not easily perceived, unless you request the person to draw his coat tight into the hollow of the waist. The reason is plain, for there are but few coats, comparatively speaking, that are cut to correspond with the shape of the person's waist, because the hollow of the waist has been hitherto guessed at; consequently it has been left to the mercy of chance, both its situation and quantity - the necessity of ascertaining which will, I am persuaded, be clearly perceived by the student.

"You having ascertained the height of the hollowest part, make a mark or dot, the same as at the height of the neck: those marks are considered centres, and their precise distances from the top will be essential, when you take the balance of the coat, which will be hereafter explained. You having made a mark at the hollowest part, suppose it to be 17 inches, continue the measure to the length of the person's waist, suppose it to be 25 inches; from thence to the bend of the knee, suppose it to be 40 , then write down 17,25 and 40 , as under, the length of the person's waist is from the socket of his neck down to the bottom of his back-bone, which is in the middle of the most bulky part of the hips. Then place the person's arm in the form of a square, and place the end of your measure at the seam in the middle of the back, and take the width of the back, 6 inches, and extend it to the elbow, 20 inches, and continued to the hand, 34, write down 6,20 , and 34 . The size round the top of the arm should be taken rather tight, that is to say, get the exact size if possible. Suppose it to be that of the most general make, say 14 inches, and in the middle 12, at the hand $10 \frac{1}{2}$; then take the height of the top of the fore seam of the sleeve, which, when the arm is bent is in the form of a square, apply the measure to the point of the elbow, and continue it to the top of the fore seam of the sleeve, take it under the arm, suppose it to be 13 inches; then take the size round the belly, by placing the measure round into the smallest part of the waist, 33 inches; then take the size round the breast close up to the arm-pits, say 36 . The size round the breast should be taken rather tight, therefore if the coat the person has on is large or loose, draw the measure nearly as tight as the size; if not, you will be deceived in the fit of the garment.

"A working man requires plenty of room under the arms, and in every other part, therefore take the size as will be suitable to 
the person it is intended for-take the size round the neck, suppose it to be 16 (the size round the neck should be taken under the waistcoat), precisely the same as you would for a military jacket; this measure frequently corresponds with half the size of the breast, but there are great exceptions. Then take the width across the chest, suppose it to be 13 inches; this measure is not always to be relied upon over the coat, in consequence of the padding of the breast and lapels, \&c., therefore it may be necessary to take a proof measure against it, i.e., from the mark made for the height of the neck in the centre of the back, take it under the arm to the front of the armhole, suppose it to be 13 also; these two dimensions being so connected with each other, I should write them down as a double measure, thus $\frac{13}{13}$. I shall next advert to that of taking the balance of the coat by measurement, which $I$ have discovered since my last publication on coats. You were desired, when taking the height of the neck and the height of the hollowest part of the waist, to make a dot or mark at each; those marks, and the top of the back seam or spine, are centres from which the most essential dimensions are taken : such as the height of the neck, the hollowest part of the waist, the length or balance of both the top and bottom points of the shoulder seams of the forepart, the front of the armhole, \&c., therefore when the person's coat is drawn quite close in to the waist behind, place the end of the measure to the mark on the back seam at the hollowest part of the waist, and lead it up under the arm, round the front of the armhole to the top of the back seam or spine, and suppose it to be $24 \frac{1}{2}$ inches; and before you remove the measure, lead it to the mark or dot made in the centre of the back between the shoulders for the height of the neck; and suppose it to be $26 \frac{1}{2}$ both taken from the same point. In taking these dimensions you should observe whether the coat the person has on at the time is too long in the shoulder or balance, or whether it be too large or loose, if so you must take care to draw the measure as much tighter as it may be required to get their real lengths, if not the forepart will be too long in the shoulder. You having correctly ascertained those lengths, I should consider them as a double measure, they being taken at once, and set them down thus $\frac{24 \frac{1}{2}}{2}$; take the hollow of the waist, by requesting the person you are measuring to hold one end of your measure fast, while you bring the other end over his shoulder, down to the most bulky part of the hip, that is to say, down to where he projects the most; the measure being kept straight in that position, represents a line from the blade-bone to the hip, from which line you can ascertain how hollow the person is in the waist, by placing a pencil case with inches, \&c., on it, or an inch rule to the hollowest part of the waist. 
"You having ascertained the exact hollow of the waist, we will suppose it to be of that form as is most general, say $1 \frac{1}{2}$ inches; but there are great exceptions, some persons are three inches hollow, whilst others have no hollow at all; but you may be deceived in ascertaining the hollow of the waist, if you do not request the person to stand in his natural position, that is to say, see that he does not make himself hollower or straighter in the waist behind than he really is, by bending himself either backwards or forwards, \&c.

"The above measures are sufficient, except any fancy dimensions are required; such as the length from top of back seam to the hip buttons, or the length of the coat, which are merely fancy, and has nothing to do with fitting the body.

"The measure being thus far completed, then write down the particulars, as may be directed by the customer, \&c., as under :-

"Copy of the Measures taken.

\begin{tabular}{l|c|c|c} 
& $5 \frac{1}{2}$ & $12 \frac{1}{2}$ & 17 \\
"Mr. "Superfine coat, pockets in pleats, & 25 & 40 & 6 \\
button, cuff, \&c. & 14 & 34 & 13 \\
b3 & 12 & $10 \frac{1}{2}$ \\
& 13 & $24 \frac{1}{2}$ & \\
\hline 13 & $26 \frac{1}{2}$ & $1 \frac{1}{2}$
\end{tabular}

"The Back (Dia. 3, Plate 4).-Lay your cloth perfectly smooth, with the double edge towards you, and we will consider the edge of the cloth to be a straight line drawn to proceed from ; find 40 inches on your tape inch measure, and place it at the bottom of the cloth, unless the coat is required longer or shorter; in that case, place the figure accordingly, and extend the measure up the edge of the cloth from top to bottom; the measure being thus placed, make a mark at the top, as at $\mathrm{B}$, and make a mark $5 \frac{1}{2}$, as from $\mathrm{B}$ at $\mathrm{C}$, and one at 17 inches from the top, as from $\mathrm{B}$ at $\mathrm{D}$; and one at $\mathrm{E}$ which is for the length of the person's waist, or to where he projects the most, which is 25 , as from $\mathrm{B}$ to $\mathrm{E}$; likewise, one at 40 , as from $\mathrm{B}$ at $\mathrm{A}$ which is for the bend of the knee; then draw a line across at the length of the person's waist, as at E, but as fashion or fancy generally requires the length of the waist of the coat shorter, therefore draw a line across, to accord with the fancy of the day, as at $\mathrm{D}$; then make a mark at the bottom as much within the edge of the cloth as you wish the coat to lap over at the bottom of the back, when on the person, suppose we say 3 inches; in that case $I$ should make a mark $1 \frac{1}{2}$ inch, and allow a sufficiency for the turning-in of the back, say 1 inch more, which would be 
$2 \frac{1}{2}$; make a mark as far from the edge of the cloth as is sufficient to form a tack over to the back, say 1 inch, as at $\mathrm{F}$; then draw the back seam line as from $G$ at the bottom to the mark at $F$, and continue it to $\mathrm{B}, \mathrm{O}$ and $\mathrm{A}$, at the top.

"Draw a line perfectly on the square with the back seam line, as from the mark at $\mathrm{C}$ to $\mathrm{H}$; this line is considered to run from the centre of the back, between the shoulders, in the direction of the elbow; then make a mark for the width of the back, according to the fancy of the day, or that of the customer ; for it matters not, whether wide or narrow, for whatever is added to or taken from the width of either of the points, whether between the shoulders, or at the hips, or at the top, whether long back scie or short, \&c. ; for it matters not what the form of the back is, as the principle in marking the forepart out cannot fail to produce a corresponding effect. Draw a line parallel with the back seam line, as from $K$ to $K$, to find the two points of the back scie upon, as at $\mathrm{L}$ and $\mathrm{N}$, leaving the line drawn for the height of the neck in the centre, as at $\mathrm{C}$; the back scie may be made any length, according to fancy. The measure for the size round the neck is 8 inches, make a mark half that distance, which is 4 , on the back seam line, as from $\mathrm{B}$ at the top of the back, at $\mathrm{O}$; then make $\mathrm{O}$ your pivot, and cast the half circle, as from $B$ to $A$, which is the neck circle or gorge, and you may use as much of it as fancy may require for the width of the top of the back; suppose it to be required a moderate width, both at the top and at the hip, as at $\mathrm{P}$ and $\mathrm{Q}$, your next object is to shape the back scie, shoulder, and side seams, by marking your pivots, which will produce their proper shape from each point respectively. But observe, this principle for shaping the seams is by no means necessary with those that have been accustomed to cutting, because their practice would enable them to shape the seams to accord with the fancy of the day without it.

"The seams being shaped, then draw the pleat line parallel with the back seam line, as from $Q$ at the bottom of the side seam to $T$ at the bend of the knee, and add as much as may be required to form a pleat with, and the back is finished.

"Directions to form the Forepart. (Dia. 4, Plate 5.)-The forepart is the principal part of the coat, consequently the most difficult to form, but by a little attention to the following rules, I flatter myself that I may presume to say no person can fail in obtaining the first principles, which are by far the most difficult; and that being accomplished, the student has nothing to fear, but to follow the designs of this accomplishment. I shall proceed as follows : in the first place, suppose the pected line $\mathrm{A}$ A to be the edge of the cloth made perfectly straight, make a mark on the edge of the cloth, as far from the bottom 
of the back as to the length of the person's waist as at F ; then make a mark as far within the edge of the cloth, at the bend of the knee, as is sufficient to form a pleat with, say 1 inch, as from $\mathrm{B}$ at $\mathrm{C}$; then look into the measure for the hollow of the waist, which is $1 \frac{1}{2}$ inch, therefore make a mark that distance, as from the mark at $\mathrm{C}$ as at $\mathrm{D}$; then draw a line, as from the mark at $\mathrm{F}$ in the direction of $\mathrm{G}$, which should be continued beyond $\mathrm{F}$; that is to say, part on the cutting board and part on the cloth, which produce the corner of a square with the edge of the cloth, and the line drawn on the reverse side of the back at the length of the person's waist, which is 25 inches from the top of back seam; form the corner of a square with the back seam line also; therefore place the one corner of the square on the other, as at F, and extend the top part of the back perfectly smooth, so that the top of the side seam is as far on the edge of the cloth as is sufficient for a lay-in, if such is required, as at I (see the position of the back); the back being placed according to the representation in the model, and while laying in that position, make a mark on the cutting board at the edge of the back seam, as at $\mathrm{H}$; then remove the back, and draw a line as from $\mathrm{D}$ at the bend of the knee to $\mathrm{H}$, continuing it as much longer as may be required, according to the length of the coat; the principal part of this line is drawn on the cutting board. This being done, you may consider it to represent the middle of the person's back, or in other words, the back seam line, continued down to the bend of the knee, which line is drawn to proceed from.

"It is the case in the back, forepart, and sleeve, or any other thing to draw a straight line to proceed from, and it matters not what direction it is drawn in, therefore it ought to be drawn in such a direction as will prove to be the most advantageous in making the most of the cloth; and as it is a custom to cut a coat with seams at the sides, in order, I should suppose, to obtain a better fit, although at the same time a fit is easy to be accomplished without them; but the custom is so prevalent, that a coat without a piece put in behind, commonly called the back, is a novelty to the greater part of the trade. But if there is to be a back cut to a certain breadth, or form, that undoubtedly should be taken from the line drawn to proceed from; therefore, whatever the width of the back may be at the top of side seam, or at the length of the waist of the coat, you must take from the line drawn to proceed from; therefore, whatever the width of the back is at the length of the fancy waist, must be taken from the line drawn to proceed from at the principal projection, as from $\mathrm{F}$ at $\mathrm{G}$. You having made a mark at $\mathrm{G}$, then place the corner of the represented square at the projection on the back, as at $\mathbf{F}$ on to the represented corner of the square on the 
cloth or cutting board, as at $\mathrm{F}$ also, and extend the edge of the back seam on the line drawn to proceed from, as from $\mathrm{F}$ to $\mathrm{H}$; the back being laid perfectly smooth in that position, make a mark at the top of the side seam of the back on the cloth, as at I for the top of the side seam. You having by those means found both top and bottom of the side seam, your next object is to shape the side seam, perfectly to accord with the person's form behind; your back being laid perfectly smooth as represented, and there being a mark on the back at the hollowest part of the waist, which is 17 inches from the top, as at $T$, and your measure tells you the person is $1 \frac{1}{2}$ hollow at that precise place, therefore you must take $1 \frac{1}{2}$ out, as from $\mathrm{L}$ at $\mathrm{K}$; you having made a mark $1 \frac{1}{2}$, as from $L$ at the edge of the side seam of the back at $K$, then keep the top of the side seam of the back fixed on the mark made for the top of the side seam of the forepart, as at I, and place the edge of the side seam of the back, as at the mark at $\mathrm{L}$, to touch the mark at $K$. The back being laid perfectly smooth in that position, mark the side seam of the forepart by the edge of the side seam of the back, as far down as the mark at $\mathrm{L}$, that being the hollowest part of the waist; it is from there that you are to commence the spring down to the principal projection, as to the mark at $G$, see the shape of the side seam continued with a gradual hollow, as from $K$ to $G$, which produces the exact shape of the person's waist behind, from the blade-bone or side seam to the most bulky part or projection below; therefore if fancy or fashion, as it generally does, requires the waist of the coat shorter than the waist of the person, you can mark it accordingly.

"The fancy length of the waist being marked, and likewise cut in the back, of course the forepart must be cut to accord with it, as at $\mathbf{M}$; then draw the pleat line, as from $M$, at the bottom of the side seam of the forepart to the mark at $\mathrm{C}$, at the bend of the knee, continuing it to the bottom of the forepart -let it be as much longer than the bend of the knee as it might be required.

"You having drawn the pleat line, then place the back and forepart in a closing position at the side seam, the same as if the seam was sewn, and mark the size of the breast, which is 18 inches, as at $\mathrm{N}$; keep the back still closed at the top of the side seam, but let the back seam edge lie on the line drawn to proceed from, and let it be open at the hollow of the waist; make a mark the size of the breast from the line drawn to proceed from, as from $\mathrm{F}$ to $\mathrm{O}$; then draw a line up the front from $\mathrm{O}$ to $\mathrm{N}$, and continue it as to $\mathrm{P}$, which is parallel with the line drawn to proceed from; then draw a line on the square, with the line drawn to proceed from, as from the top of the side seam across 
to $\mathrm{Q}$ in front, to find the front of the armhole upon; the measure for the half width across the chest is $6 \frac{1}{2}$ inches, make a mark that distance from the front line, as from $Q$ at $R$, then close the side seam as if sewn, and mark the bottom of the armhole, which is $12 \frac{1}{2}$ inches from the top of back seam to $\mathrm{S}$ (see the line as from the top of back seam to $\mathrm{S}$ at the bottom of the armhole); the side seam being closed, see if the width across the chest corresponds with the measure taken for the front of armhole from the back seam line, as from $\mathrm{H}$, at the mark taken for the height of the neck to $S$, and continued to $R$.

"If both these measures are taken correct, they will correspond with each other; but if they do not, if you divide the difference between the two, you cannot fail to be nearly correct. Most of the modern cutters make use of the proportions of the breast to find the front of the armhole, such as one-third from the front, or two-thirds from the back seam, either of those will frequently answer; but there are great exceptions, they cannot be equally correct as a measurement : for example, two persons may exactly correspond in size round the breast, but the one might be full chested and the other narrow chested, therefore the one would be too wide over the chest, and the other too narrow; and the one that is too wide in front would be too narrow behind, and the one that is too narrow in front would be too wide or too large between the shoulders, i.e., between the two back scies; therefore, taking the width across the chest is far preferable to depending upon the proportions of the breast.

"You having made a mark for the front of armhole, and the side seam being closed from top to bottom, the mark made for the hollowest part of the waist, which is 17 inches from top of back seam, would be precisely at $\mathrm{T}$, which is the centre to get the length or balance of the forepart from when closed in the shoulder searn; first mark the length to the top of back seam, which is $24 \frac{1}{2}$ inches, as from $T$ round the front of armhole, as at $R$, continued to the front line at $V$, see the dotted line as from $\mathrm{T}$, round the front of armhole and continued to $\mathrm{V}$, which should be $24 \frac{1}{2}$ inches according to the measure taken, and $26 \frac{1}{2}$ to $U$, taken in the same directions as from $T$ to $R$, and from $R$ to $\mathrm{U}$. Make $\mathrm{R}$ at the front of the armhole your pivot, and cast a circular line, as from $\mathrm{V}$ to $\mathrm{V}$, every part of which is $24 \frac{1}{2}$ inches from $\mathrm{T}$, as before described; also make $\mathrm{R}$ your pivot, cast a portion of a circle as from $U$ to $U$,- the size of the neck being 8 inches, half of which is 4 ,- therefore make a mark that distance, as from $\mathrm{V}$ on the circular line at $\mathrm{W}$, which is for the top of the back seam; then make a mark for the height of the neck; which is $5 \frac{1}{2}$, as from the circular line, as at $\mathrm{X}$ in a straight direction, which should be the distance of the height of the neck from each other; draw a line, as from the mark at $\mathrm{W}$ to the 
mark at $X$, so as to touch both the circular lines, and continue it as from $\mathrm{W}$ to $\mathrm{Y}$ on the front line, and as from $\mathrm{X}$ to $\mathrm{Y}$ at the bottom of the back, which may be termed the back seam or balancing line when closed in the shoulder seam; make the end of the line, as at $\mathrm{Y}$ on the front line your pivot, and cast the neck or gorge as from $\mathrm{W}$ to $\mathrm{Z}$, then prove it by measuring round it, as from $\mathrm{W}$ to $\mathrm{Z}$, and if it corresponds with the neck, which is 8 inches, it is correct, but if it does not it must be cast by such a distance as will produce it to the size of the neck; but you will invariably find half the size of the neck will produce it as required, if it is correctly cast.

"Your next object is to produce the shoulder seam and armhole, therefore place the top of the back seam to the upper end of the gorge circular line, as at W, keeping the edge of the back exactly on the top balancing line as from $W$ to $X$ and $Y$, and the form on the top of the back will be found to correspond with the gorge of the forepart, as from $\mathrm{W}$ to $\mathrm{B}$; the back being perfectly smooth in that position, make a mark at each point of the shoulder seam of the back, as at B and C, for the points of the shoulder seam of the forepart; your back being in a closing position in the shoulder seam, and the back scie being part of a circle, continue it in the direction of the front of the armhole, as from $\mathrm{C}$ to $\mathrm{R}$, then place the back in a closing position at the side seam, and continue the back scie circular, as from $I$ to $\mathrm{S}$ and $R$, which completes the form of the armhole. Then mark the length of the lapel, and shape the bottom of it perfectly on the square with the line drawn to proceed from (see the line, as from M, at the bottom of the side seam, to the front edge); then draw a line on the square also, as from $\mathrm{S}$ to $\mathrm{N}$, which represents where the size of the breast was taken; and your next object is to ascertain the form of the person in front, before you can attempt to shape the lapel, therefore place the back in a closing position at the side seam, as from I at top to $K$ in the small of the waist, the measure for the half size round the hollowest part of the waist or belly, which is $16 \frac{1}{2}$ inches, therefore apply the measure across, and make a mark at $16 \frac{1}{2}$ as at $\mathrm{F}$ (see the dotted line, as from the small of the waist to $\mathrm{F}$,) in front; then mark the size of the breast, as at $\mathrm{N}$, and allow what is sufficient for the making up, say 1 inch (see the shaping of the front in the plate); and if a lapel is required, that of course is formed suitable to the fancy of the customer.

"The width of the skirt is entirely fancy, therefore that also must be shaped accordingly. The gorge in its present state is what may be termed military, i.e., a close circle round the neck when the garment is buttoned up on the person; but that can be shaped lower, or in any direction as may be required to accord with the fancy of the day, or that of the person it is intended 
for; it is for the most part required to be shaped lower in the front from about the middle, as from $B$ to the front edge; this being done, the forepart is completed, but I should omit cutting of it, until the sleeve is marked out."

Attention has been principally devoted to the method of producing coats, but Mr. Hearn's works are too important and too voluminous to be passed over without our showing his system for cutting breeches, pantaloons, and trousers. The drafting of breeches is now occupying considerable attention, and any production of Mr. Hearn's merits our close examination, because it is the result of much thought and frequent experiment. Besides, it gives us pretty accurately an insight into the best modes of cutting breeches as practised in 1819 .

Following the plan which I have laid down, I shall give his instructions in his own language, so that his thoughts and manner of expressing them should be before the minds of the readers :-

"Method of Measuring for Breeches. (Dia. 1, Plate 5).--Place the end of your measure as high as the person wishes them to be, and if that is above the hip bone, notice the distance from thence to the hip bone; suppose it to be 3 inches, as from $A$ to B (see $A$ at the top of the side seam, and B 3 inches below it), keep your measure fast at the hip, and extend it to the cap of the knee, as from $\mathrm{B}$ to $\mathrm{C}$ (see the dotted line drawn as from $\mathrm{B}$ at the hip to $\mathrm{C}$ on the cap of the knee), suppose it to be 25 inches; and before you remove the measure from the hip, extend it down the side of the thigh to the length required, as to $\mathrm{D}$, and make a mark with a piece of chalk, as at $\mathrm{D}$, and suppose it to be 29 inches. Your next object is to take the length from the centre of the stride to the small below the knee; likewise the length of the leg seam; also the exact height you intend taking the size round the middle of the thigh; these are the most essential measures required. Most cutters are accustomed to find the length of the leg seam by methods that are very little better than guessing; and yet this measure is one of the most important that can be taken, for if the length of that seam be not correct, how is it possible for the different sizes to be correct, as they must rise or fall according to the height of the top of the leg seam. It is also necessary, if the breeches are required to fit close, to take the heights of the sizes in the different parts of the thigh. The second cause of the difficulty of cutting breeches to fit to a nicety, is the want of a just proportion to produce the stride; which proportion is previously requisite, in order to ascertain how much the side seam must be hollowed, for that being produced you can with propriety find the true position of the point or centre, from which the stride should take place. 
Plate 5.

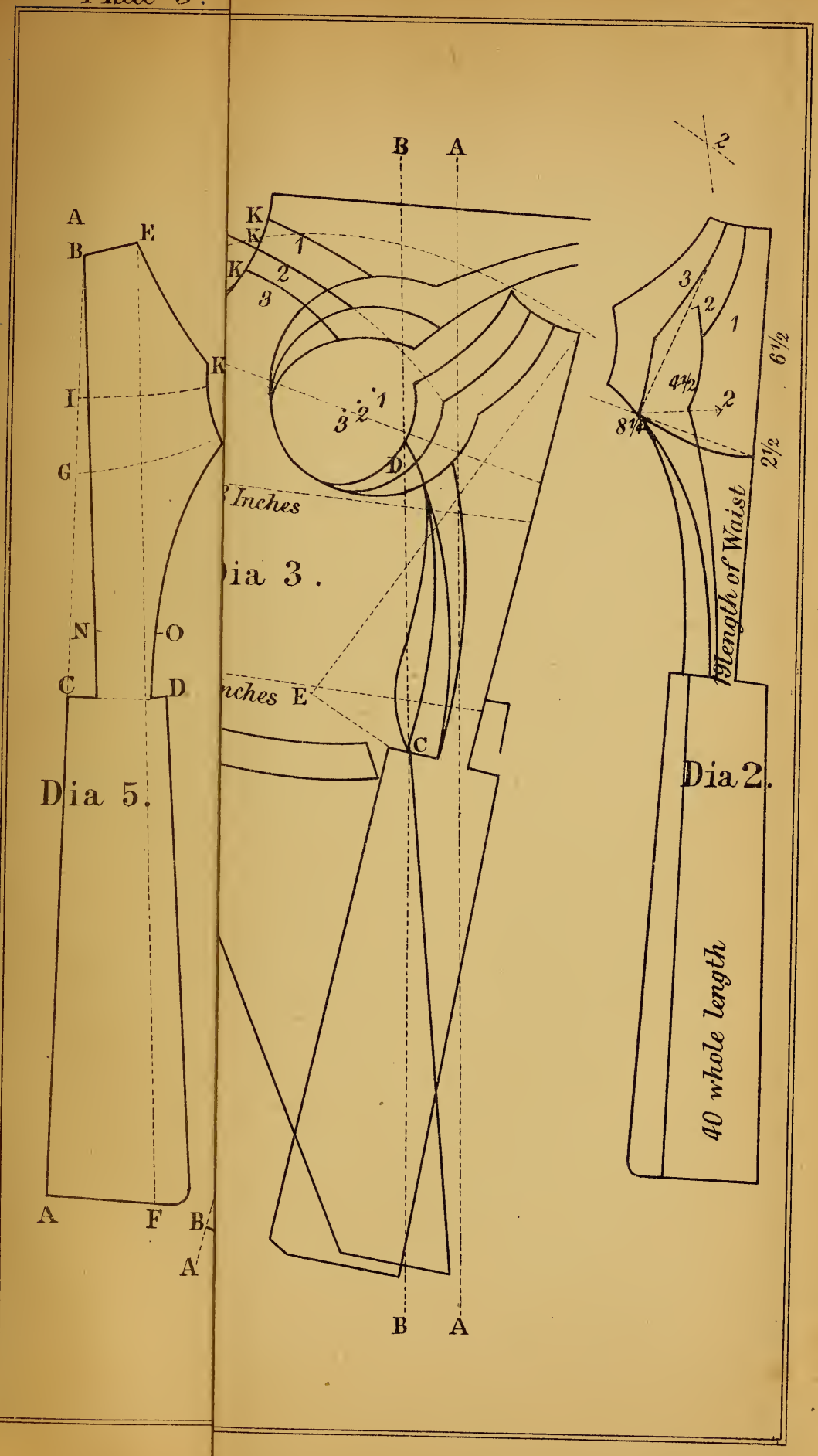


Plate 5

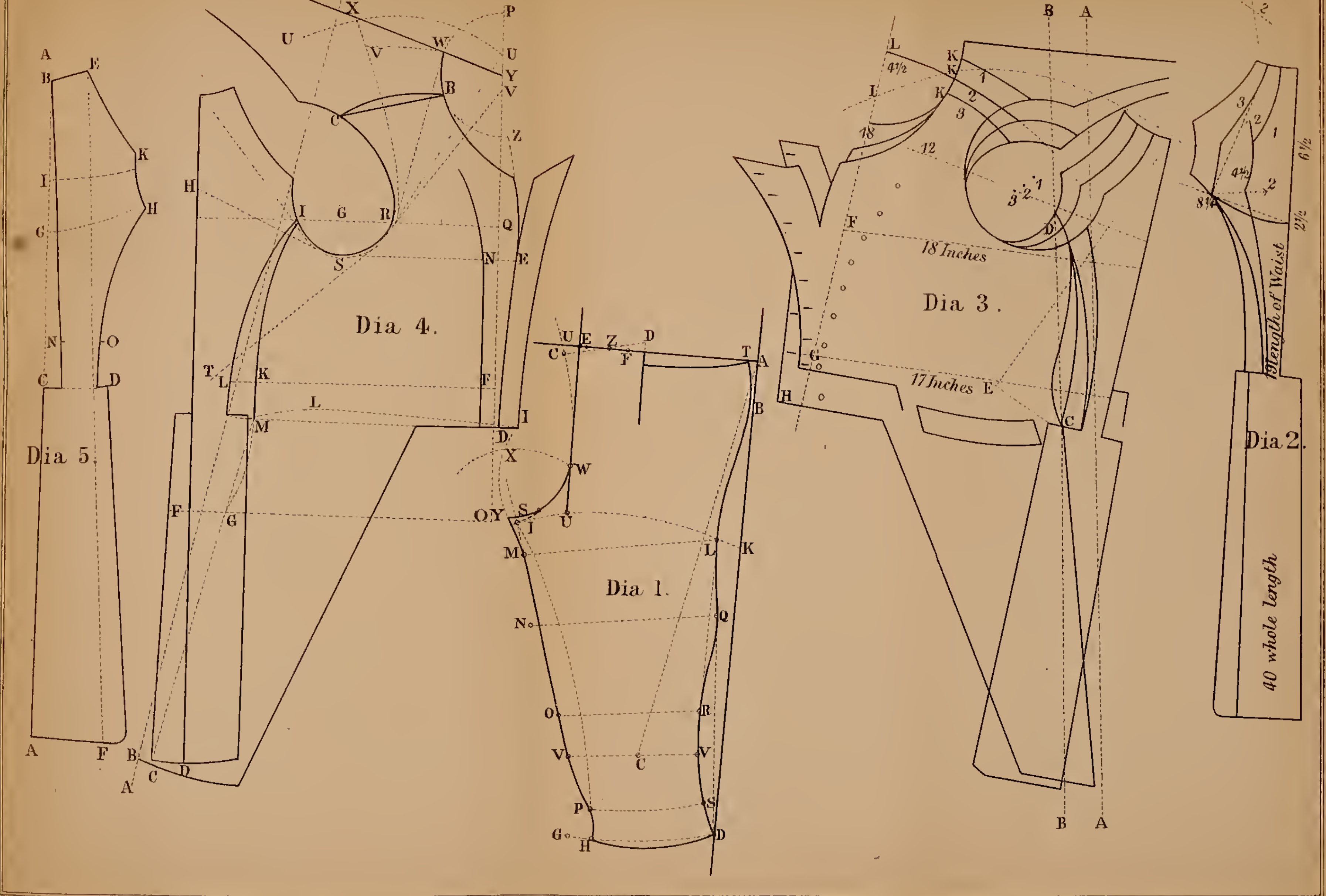



"To ascertain the true point of the fork, or the top of the leg seam, various methods have been adopted by different writers and teachers. Some have taken the distance from the hip to the fork, by placing the end of the measure at the top of the side seam, on the hind part, and down the seat, bringing it between the legs, and up the front to the top of the side seam of the forepart; the half of which is a guide for the top of the leg seam. Others will direct you to make your pivot at the small below the knee, and to draw a circular line, the sixteenth of the person's height, which is the length from the hip to the fork, to find the top of the leg seam, and many other methods which would be useless to name; but they all seem sensible of the difficulty of cutting breeches to any degree of certainty, without taking the measure of the leg seam; but I flatter myself that the following method will be found to answer the purpose of ascertaining those measures which are generally acknowledged to be so essential, and at the same time they are considered not to be attained so as to be depended upon. In the first place, your tape inch measure should have a ring fastened to it at the end where the figures commence, and in such a manner that the inches commence from the end of the ring; considering that to be the case, then take a piece of whipcord or string, and make a noose at one end of it, and hang it on to one of the hip buttons of the person's coat, and place the ring of your tape inch measure, and draw the string between his legs, and request the person to draw it tight up from his hipbutton towards his breast; such being the case, take hold of your measure and slide the ring on the cord to the centre of the stride, and lead it down the side of the thigh with the figure-side outwards, and make a mark with a piece of chalk as low down as the place where you intend taking the size of the full of the thigh, suppose it to be 6 inches, as at $\mathrm{N}$.

"Having made a mark at the distance of 6 inches from the centre of the stride, continue the measure down the side of the thigh to a little above the knee, and make a mark as at $\mathrm{O}$, supposing it to be 12 inches; keep your measure fast at $O$, continuing it to the smallest part below the knee-bone, as at $\mathrm{P}$, supposing it to be 18 inches; continuing the measure to the length, which should be exactly opposite the mark made where the length of the side seam was taken to, supposing it to be $19 \frac{1}{2}$ inches; then write down $6,12,18,19 \frac{1}{2}$, which are for the height of the different sizes of the thigh; then take the size round the bottom, which should be taken exactly at the mark made for the length of the side seam, as from $\mathrm{D}$ to $\mathrm{H}$, and supposing it to be 14 inches; then round the smallest part below the knee, which should be taken very tight, particularly if the breeches the person has on be in wrinkles, as they frequently are, 
supposing the size to be 13 inches, as from $\mathrm{P}$ to $\mathrm{S}$, then take the size round as at $C$, which is over the cap of the knee, as from $\mathrm{V}$ to $\mathrm{V}$, suppose it to be 15 inches; then write down 14, 13 , and 15 ; then take the size a little above the knee, as from the mark made 12 inches from the centre of the stride, as from $O$ to $R$, which is 16 inches: then take the size round at the mark made at $\mathrm{N}$, which is 6 inches from the centre of the stride, as from $\mathrm{N}$ to $\mathrm{Q}$, suppose it to be $21 \frac{1}{2}$ inches; then take the size round the top of the thigh, as high up as you can well get the measure towards the centre of the stride, as from $\mathrm{M}$ to $\mathrm{L}$,

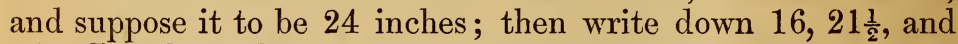
24. In taking this measure, if the breeches the person has on are large or loose, perhaps dropped down for want of being properly braced up, request him to draw them up so that you can get a fair measure, and always avoid taking the size of the top of that thigh which his shirt is stuffed down, which may, if not avoided, add considerably to the size. Having taken a correct size round the top of the thigh, then take the size of the waistband, which is 38 , likewise the size round the full of the seat, which is 45 inches; the last measure required is the hollow of the thigh, which can be ascertained by placing your tape inch measure to the side of the thigh, requesting the person you are measuring to hold the measure fast to the side of his thigh, as at $\mathrm{L}$ or at the hip; in the meantime you should extend the other part of the measure to the mark you made when you took the length of the breeches, as at D. Your measure being kept tight in that direction, it will, of course, form a line, as from L to D; your next object will be to ascertain how far the hollowest part falls within that line, as at $R$; suppose it to be 1 inch, which is the most general, your measure is completed; but it may be necessary to observe, when you are about to take this measure, you should request the person to place his leg and thigh perfectly straight or stiff, the same as it is when in his natural standing position, and the most hollow part will be found generally a little above the cap of the knee.

"I would here desire to call the attention of the reader to the measure taken from $B$ at hip to $C$ at the cap of the knee; as I have known some breeches makers who presumed they were original discoverers of this measure, and who prided themselves upon its possession as an important trade secret, the only difference being that they took their measure from the fork to the knee cap.

"T'he Copy of the Measure taken in whole numbers.-3, 25, 29 ; $6,12,18 ; 19 \frac{1}{2}, 14,13 ; 15,16,21 \frac{1}{2} ; 24,38,45 ; 1$.

"Directions to form a pair of Breeches. (Dia. 1, Plate 5).Suppose the edge of the cloth to be a straight line drawn 
to proceed from, and the line as from $A$ to $U$ to be the top edge of the cloth, made perfectly square, then make a mark, as at $B$, to represent the hip-bone, 3 inches; then keep your measure fast at $\mathrm{B}$, and extend it in the direction of the centre of the knee, and make a mark at the distance of 25 inches, as from $\mathrm{A}$ at top, as at $\mathrm{C}$, which represents the centre or cap of the knee (see the dotted line drawn as from $\mathrm{A}$ to $\mathrm{C}$ ); this being done, keep your measure still fast at the hip, and extend it down the edge of the cloth to the length of the breeches, which is 29 inches; having made a mark as at $\mathrm{D}$, the $\frac{2}{3} \mathrm{rds}$ of the half thigh measure are 8 inches; make a mark 8 inches from the top corner of the cloth, as from $\mathrm{A}$ at $\mathrm{F}$; then make $\mathrm{F}$ your pivot and cast a circular line, as from $D$ to $G$, to find the size at the bottom upon (see the dotted circular lines, as from D, the bottom of the side seam, to $G$ ); the size at the knee-band is 7 inches, and make a mark for the size at bottom as at $\mathrm{H}$; before you mark the length of the leg seam, observe, in taking this measure, it is taken from the centre of the stride in a perpendicular direction; but the centre of the stride and the top part of the leg seams, when on the person, forms a sort of a curve; therefore, as you did not measure that curve, you must allow as much as you may suppose your length would be longer if taken in the form of the curve, instead of being taken straight. I generally allow 1 inch, that is for a medium size, and so in proportion according to the size; therefore, the leg seam being $19 \frac{1}{2}$ inches, and 1 inch allowed for the curve or stride, which is $20 \frac{1}{2}$ inches, therefore make the mark at $\mathrm{H}$ at the bottom of the leg seam your pivot, and cast a circular line by $20 \frac{1}{2}$ inches, as from $I$ to $K$ (see the dotted circular line, as from $I$, the top of the leg seam, right across to. $\mathrm{K}$, at the edge of the cloth); this being done, make a mark half the fourth, which is $1 \frac{1}{2}$, from the line drawn to proceed from on the circular line, as from $K$ at $\mathrm{L}$; then make a mark for the size of the top of the thigh, as from the mark at L, at M, which should be marked within 2 inches of the circular line cast by the length of the leg seam: for observe, when you take the size of the top of the thigh of a person, your aim is to take it as high as you can with propriety, but, as before observed, the stride or fork being of a curve, you cannot get the size nearer than about 2 inches of the top of the leg seam; you having marked the size of the top of the thigh, then draw a straight line at the side seam, as from the mark at $\mathrm{L}$, to $\mathrm{D}$ at bottom. (see the dotted line, as from $\mathrm{D}$ to $\mathrm{L}$ ), which represents the measure when placed to the side of the thigh to ascertain the hollow, when taking the measure, and, if you look into your measure, you will find the hollow to be 1 inch, which is taken in the hollowest part, which is generally about 2 inches above 
the knee, as at R. You having made a mark as far within the line as the hollow is, as at $\mathrm{R}$, then draw a straight line, as from $\mathrm{R}$ to $\mathrm{L}$ (see the dotted line, as from $\mathrm{R}$ to $\mathrm{L}$ ), then shape the bottom of the side seam with a gradual hollow, as from $R$ to $D$, at the bottom, likewise shape the top of the side seam, as from $\mathrm{L}$, gradually to A at top; and if the length at top is carried higher than the hip-bone, which is generally the case, round off the top, as from $\mathrm{B}$, which is considered as the hip-bone, or the most bulky part, to T, according to the shape of the hip, which will cause the breeches to be easy over the hips; likewise, with those who do not wear braces, it will prevent them from dropping down off the hips. Then make the marks for the heights you took the sizes of the thigh; your leg seam length being $19 \frac{1}{2}$ inches, place the figures $19 \frac{1}{2}$ on the mark made for the size at the knee-band, which is the bottom of the leg seam, and extend the measure to the mark made for the size of the top of the thigh, as at M, your measure being so placed with the figured side upwards, then make a mark at 6 , and one at 12 , and one at 18 , as at $\mathrm{N}, \mathrm{O}$, and $\mathrm{P}$, which are the distances from the top, from which you took the various sizes of the thigh.

"Next mark the size of the small below the knee, which you will find to be $6 \frac{1}{2}$ inches, as from $\mathrm{S}$ in the direction of the mark made for the height of the small below the knee, as at $\mathrm{P}$, then mark the size over the knee-bone, which is represented by the mark at $\mathrm{C}$ in the centre to $\mathrm{V}$ and $\mathrm{V}$, then mark the size at the mark at $\mathrm{O}$, as from $\mathrm{R}$ at $\mathrm{O}$ a little above the knee, which will be found to be 8 inches; likewise mark the size in the middle of the thigh, as from $\mathrm{Q}$ in the direction of $\mathrm{N}$ at the mark made to know the height you took the size in the middle of the thigh; this being done, draw a line perfectly straight, as from the mark at $M$ to the mark made for the size over the cap of the knee at $\mathrm{V}$, continuing it to cross the circular line at I, which gives you the top of the leg seam. Observe, the leg seam line should invariably be drawn from the size at top to the size over the bulge of the knee, as at $\mathrm{V}$, without studying the size at $\mathrm{O}$ and $\mathrm{N}$. You having drawn the leg seam as low as the bulge of the knee-bone, which is generally opposite the cap of the knee, or a little below it, as between $\dot{V}$ and $\mathrm{P}$, then shape the bottom part of a gradual round, as from $\mathrm{V}$ to $\mathrm{P}$, which will produce it to correspond with the bulge on the inside of the knee; this being done, add the spring below as from $\mathrm{P}$ to $\mathrm{H}$, then make a mark one-fourth, which is three inches from I, where the leg seam line crosses the circular line cast by the length of the leg seam, as from I at $U$, then measure the distance, as from $\mathrm{U}$ to $\mathrm{K}$ on the line drawn to proceed from at the side seam, which is 11 inches; then make a mark the same distance at top from the line drawn to proceed from, as from $A$ to $U$, 
then draw a line from $U$ to $U$, which forms part of the fall-down seam ; then make a mark one-fourth from the mark at $U$, as at $\mathrm{W}$, then make the point at I your pivot, and cast a circular line, as from $W$ to $\mathrm{X}$; then make the mark at $\mathrm{W}$ your pivot, and cast a circular line, as from $\mathrm{I}$, which produces a centre as at $\mathrm{X}$; then make $\mathrm{X}$ your pivot, and cast a circular line, as from $\mathrm{W}$ to I, which produces the fall-down seam. Your next object is to add as much stride as may be required, as from the size of the top of the thigh at $M$ to $Y$, say $\frac{1}{2}$ an inch, which will be sufficient; likewise give the same quantity to the point of the fall-down seam, as from $\mathrm{S}$ to $\mathrm{Y}$.

"Next ascertain whether the person has any bulge or round at the side of the middle of the thigh, as from $\mathrm{N}$ to $\mathrm{Q}$, or in the middle between $R$ and $L$, as at $Q$, which is proved by the size, which is $10 \frac{3}{4}$ inches; for observe, when you drew the line for the leg seam, the mark for the size of the middle of thigh, as at $\mathrm{N}$, projected, consequently, as much as that mark is from the leg seam line, so much must be added at the opposite side in the middle between $\mathrm{R}$ and $\mathrm{L}$, as at $\mathrm{Q}$, and shaped with a gradual round, as from $\mathrm{L}$ to $\mathrm{Q}$, and continued to $\mathrm{R}$, which produces the bulge or round according to the shape of the side of the thigh. This being done, thus far the foreparts may be considered completed, if for a proportionate made person. You having completed the forepart, I refer you to the Pantaloons (Dia. 4, Plate 4) for instructions to form the hindparts.

"There are many persons whose knee-bone is inclined to bulge in the inside; when such is the case, the leg seam requires to project with as much round as may be necessary, according to the projection of the knee-bone; but this is readily ascertained, for the hollower the person is at the side of the thigh, as at $R$, the greater the bulge on the opposite side.

"You have, for instance, ascertained by measurement that this person is 1 inch hollow at the outside of the thigh, as at R; but supposing the same person had been $1 \frac{1}{2}$ inch hollow, in that case he would have bulged so much the more at the bone; a little below the knee at the leg seam; and if hollow in the extreme at the side seam, the bulge on the opposite side would be so great as to cause the person to be what is called knock-kneed; but those who are not accustomed to take the hollow of the thigh (and I must confess I have never heard of any individual besides myself that has done it), they certainly can but guess at the form, which can be no criterion for fitting. The breeches might correspond with the size of the measure without being anything like a fit; for if the side seam is straighter than the form of the thigh, of course the leg seam is hollower; in that case, when buttoned at the knee, they will set full between the buttons, which is an egregious error, but a very common one. And what 
is the cause? Why, the reason is this : the side seam is not sufficiently hollowed at $R$, and, I believe I may say with propriety, that nine out of ten (take the trade through) are in this error; for I believe the general practice of cutting breeches is that the side seam is cut too straight; in fact, for the most part, it is cut entirely by idea. It is true some have a better idea than others, but, where a principle is clearly laid down, anyone possessed of common sense cannot avoid gaining the information intended to be conveyed; but I am well aware of the difficulty there is to take old practitioners out of the way they have been accustomed to.

"Directions for Pantaloons (Dia. 4, Plate 4).-Taking the measure for a pair of pantaloons is precisely the same as a pair of breeches, except the length, therefore I need not explain the taking the measure, as it would be a repetition of the same thing.

"The difference between the measure for breeches are the lengths, which are 41 instead of 29 inches, and the length to the pitch or point of the calf, is 22 inches, instead of $19 \frac{1}{2}$, where the length of the leg seam was; and the hollow at the side of the thigh is $1 \frac{3}{4}$, instead of $1 \frac{1}{2}$; the reason why this is more than if for breeches is because in taking the hollow for a pair of pantaloons you should form your line with your measure, as from the hip down as low as the calf, whereas you would form it from the hip to the length of the breeches, consequently the projection of the calf is more than at the length of the breeches, except the breeches is required as low down as the middle of the calf.

"Directions to form the hind parts of Pantaloons, Breeches, \&c. - First, make C at the top of leg seam your pivot, and cast a circular line from $\mathrm{P}$ to $\mathrm{R}$, and add as much more to it on the circular line as will cause the top of the pantaloons to be the size of the waistband, as at $R$; that being done, draw a straight line from $\mathrm{R}$ to $\mathrm{C}$, then take the size round the seat by placing the end of the measure as at $\mathrm{T}$, and extend it to $\mathrm{V}$ in the side seam; and from $\mathrm{V}$ back in the same direction to the seat seam, and make a mark the size of the seat, which is 21 , as at W, and mark the form of the seat as from $\mathrm{C}$ to $\mathrm{W}$ and from $\mathrm{W}$ to $\mathrm{R}$.

"Trousers (Dia. 4, Plate 4).-In taking the measure for a pair of trousers, first take the length from top of the side seam to the centre of the knee, then the length from top of side seam to ankle, then the length of the leg seam from the centre of the stride to the bottom, then take the neat size round the top of the thigh, then the size of the waistband, which makes five measurements, and is sufficient, except the person requests them to a particular size down the legs; if so, take what measures you may deem necessary.

"In respect to forming a pair of trousers, I well know most 
persons form them with a straight side seam, consequently a hollow leg seam, which, as I have stated in breeches, is not consistent; but some are apt to think anything will do for a pair of trousers; anything certainly does do, but there is a great difference in doing. I am well convinced a pair of trousers with a hollow leg seam cannot set as they ought to do; in the first place, they will hang too close to the ancle on the outside at the bottom, and consequently the size will be all on the inside, which is a disgusting error, the reason of which is because the leg seam is too hollow at the knee-bone, which, in fact, rather than be of a hollow, they had better project. Trousers require to be hollowed in the side seam the same as breeches, if they are required small at the knee, that is to say, if they are to fit the knee, \&c., the same as pantaloons, but are to be in the form of trousers at the bottom; in that case they would be termed pantaloon trousers-they should not be hollowed in the leg seam; but suppose you want them to be large, in that case you should produce the mark to hollow the side seam, as at $\mathrm{E}$, the same as in breeches, and mark the size of the top of the thigh, as at $\mathrm{F}$, which is the same size as if for a pair of breeches, that is to say, the real size; likewise make a mark for the size at the bottom, and draw a straight line from one mark to the other for the leg seam; and if they are required larger than the real size at top, let it be given from the side seam."

A large space has been devoted to the works of Mr. Hearn, but this was necessary and justifiable, if the number and variety of his writings are taken into consideration, as well as the number of years he devoted to their composition.

The earliest work of Mr. Hearn's was published without date. The Coat System, one edition of which was published in 1818, reached a fifth edition. His works contain systems for cutting Coats, Vests, Trousers, Breeches, Greatcoats, Habits, \&c., so that tailors were provided with some rules to guide them. In addition to his writings on and teaching of Cutting, he published the "Cyclopædia of British Costumes," a magazine containing illustrations of the fashions of the period, as well as patterns of some of the more fashionable materials, and letterpress descriptions of the various styles. The illustrations, however odd and even ridiculous they may appear to us, must have been of considerable assistance to the tailors of that period. Up to the present, I have not met with any mention of a prior English Gentleman's Fashion Journal, so it is extremely probable that he was the originator of English Fashion Journals. Mr. Hearn's methods were continued by his successor, Mr. G. Walker, in his "Tailor's Masterpiece," which will be noticed in due time. 
The claim that Mr. Hearn has to our respect and gratitude is founded on the fact that he is most probably the first English author who reduced the Art of Cutting to precise rules. His mind was ever active, and his works show that his ideas were progressive. He was the first to use direct measurement to ascertain the dimensions of parts of the body, and some of the measures which he was the first to apply are used by tailors of the present time.

The lifelong labours of $\mathrm{Mr}$. Hearn were devoted to his favourite pursuit, the study of the Art of Cutting. To his genius the trade will ever remain indebted. His services have scarcely been acknowledged, much less have they been adequately rewarded. Few tailors know his name, much less do they appreciate his labours for their benefit, or render him the honour which is his due. Taking into consideration the period in which he lived, the paucity of knowledge of the Art of Cutting at that time, the devotion of years of study to the subject, and the results he bequeathed to the world, our trade owes him a debt of gratitude. At this period we can only venerate his name, and place him on one of the highest pedestals in our gallery of Trade Worthies.

His works remain: a fitting monument of his indefatigable industry, and a record of his name. The ideas he originated will live long after he is forgotten, and permeate by their force of truth and justness the minds of unborn thousands. $\mathrm{He}$ should live in our memories as one of our great Trade Worthies. May we emulate his diligence and devotedness, and leave equally worthy mementoes of our existence. Peace be to his memory, and honoured be his name.

In Mr. Golding's "Tailor's Assistant," published in 1818, we meet with the statement that "The scheme of the system is founded upon the application of geometrical rules and principles to the anatomical proportions of the human figure." And though there is very little geometry applied, and still less anatomy, we have here the glimmering of the truth, that the true basis of cutting is founded on the anatomy of the human figure, and the application of the method must be by geometrical rules. Besides observing the working of the various methods used by the old masters, we must note the principles which underlie all methods, whether understood or not or used unconsciously by the authors. Methods or systems are only means of applying principles. Consequently principles are the more important, and should be first observed and studied, and then the mechanical operations by which they are carried into effect noted afterwards.

What was considered a proportionate figure by our author differs considerably from our present notions of proportion. He says: "I consider a man to be proportionately formed, 
whose breast measure exceeds the waist about an inch, and whose waist length exceeds the breast width an inch." The measures which he gives are, "from top of back seam to waist 19 inches, round the breast 18 inches, and round small of body at waist, 17 inches." The way he directs his pupils to obtain the natural waist length seems quite droll; he adds, "the true or proportionate waist length is to be ascertained by taking the measure from back seam to elbow point, the arm forming a square." His knowledge of anatomy must have been very limited, or else he would have directed his students to have simply measured to the waist, when they required the natural waist length.

The method is laid down for cutting coats without any waist seam, so it is evident that coats with waist seams were not usually worn, or not worn at all. Further on in the work, when giving "instructions for cutting the single-breasted frock coat, or, as more fashionably designated, the Wellington Frock," we have the first introduction of a part of the waist seam, in the form of a horizontal fish, which was taken out at the waist, then seamed and rantered. The writer continues: "the waist is required to button very tight, and as this occasions a great deal of creasing in the hollow above the hips, it is therefore customary, and seems necessary, that a piece should be taken out to prevent this, - about two-thirds across the forepart towards the front; this is represented in the plate by the curvilinear lines, which gradually terminate in a straight line at the extremities; the upper side of this hollow may be stretched, and the surplus taken off at the side seam; the seam across is then to be neatly sewn up and rantered, and you will find it fit very clean and smooth, both in the hollow and round the hips." A note is added which says, "some persons cut the forepart quite across, but to me it appears unnecessary." Another observation seems called for here: we should note the introduction of the Frock coat as a new style of coat. The terms straightness and crookedness are both mentioned here as words well understood, and requiring no explanation, as we see by the following directions: "When cutting for a person who stoops forward, and whose belly measure is less than the breast, let the slioulder point of forepart be nearer the front line than usual, and cut the scye rather forwarder than the rule, thus producing a straighter forepart, and vice versa; when your figure is upright, and the waist equals or exceeds the breast, you will then require a more crooked forepart, and of course will throw the shoulder point backwarder, thus forming a more crooked forepart accordingly."

The inch measure seems to be used, as the directions are given to record the measures in every case in inches. 


\section{THE COAT.}

"The Coat being the principal part of dress, I shall commence the business of instruction with that garment, observing, that as it is to the young and inexperienced this work is principally directed, I shall therefore confine myself to the most plain and simplified method and manner in the description of the figures.

"I have chosen for a model of delineation a figure of medium size, and of that form which is most permanent, or the least likely to be affected by the changes of fashion; and from which as a standard any or every fashion may be clearly deducible.

"Of the Back. (Dia. 5, Plate 5.)-The back is invariably the first part of a coat to be cut : let the line AA be considered the edge of the cloth; take then the length of back from the bottom to the vertebræ colli, or top, as at B, say 40 inches, place the end of your measure at $B$, extend it along the edge downwards, and cast the curve $\mathrm{CD}$, being the length of waist, or 19 inches from the top; next draw the back seam from the extreme edge at $\mathrm{B}$ down to the waist $\mathrm{C}$, at about an inch and a-half from the edge, or whatever distance you may deem sufficient for a tack-over to the back; now draw the dotted line $\mathrm{EF}$ the whole length, and parallel to the back seam, at the distance of $2 \frac{1}{4}$ inches (or one-eighth of breast measure) therefrom, which gives you the proportionate width for both top and bottom of your back, and also the point of plait at the bottom of skirt; next mark the point $\mathrm{E}$, being the waist length from the intersection $\mathrm{D}$, which determines the true situation of the top of the shoulder. Your attention will next be directed to the dotted curve $\mathrm{GH}$ for the purpose of ascertaining the lower point of back scye, and which is also the top of side seam, and is thus obtained: by placing your measure (or compass) at B, extend them down the back seam half the waist length (in this example $9 \frac{1}{2}$ inches), and cast the curve $\mathrm{GH}$; the point $\mathrm{I}$ is $6 \frac{1}{3}$ inches (being the third part of waist length) from the top ; from the point $I$ then on the back seam take $4 \frac{1}{2}$ inches (or the fourth of breast measure) across for the breadth of back; next mark the point $\mathrm{H}$ on the dotted curve $5 \frac{1}{2}$ inches from $\mathrm{G}$, which is an addition of 1 inch as a spring requisite for this point; from the point $\mathrm{H}$ now proceed to find the top of back scye by dividing the space between $\mathrm{H}$ and $\mathrm{E}$ into three equal parts; one part of which take for the scye being $2 \frac{3}{4}$ inches, and the other two parts being $5 \frac{1}{2}$ inches, for the shoulder, thus determining the point $K$ as the bottom of the shoulder seam, or top of scye, represented in the Plate by the dotted line drawn obliquely from $\mathrm{G}$ to $\mathrm{H}$, which line is in this example $8 \frac{1}{4}$ inches from the top.

"I shall now point out, in a scientific manner, the method of casting the curvatures, or hollow shape of shoulder, scye, side, 
\&c. Thus, take double the length contained between each of those points and extend the same to a position which is equidistant therefrom, respectively, and cast the curves and counter curves. The breadth of the plait may be cut about an inch beyond the parallel, or any other breadth your fancy may direct, and the bottom of the skirt is to be balanced from the top of the back seam at $B$.

"Of the Forepart (Dia. 3, Plate 5).-The forepart is undoubtedly the principal part of a coat, for as it is the largest, it is also the most complicated, arising from its variety of shape; nevertheless, by an attentive application of the following rules, its formation will be clearly evinced and practically explained.

"First let the line A A be considered as the edge of your cloth, draw the parallel line B B full 2 inches distant therefrom; next place the bottom of your back skirt to nearly the bottom end of the cloth, and a little (say half an inch) within the line A A, or edge, extend the back even upwards, and mark the bottom of waist or hip, as at $\mathrm{C}$, on line B B ; next mark the point $\mathrm{D}$, or top of side seam, half an inch beyond the parallel line : the proper form or shape of side seam you will easily obtain, as follows:-First, while the back lies in the first or inverted position (touching the points $\mathrm{C}$ and $\mathrm{D}$ ), mark the lower part of the side by the curvature of back; next, by reversing the position of back, you may complete the side seam to the top.

"Now place your back in the closing position, mark your widths of breast 18 inches, and belly $16 \frac{7}{8}$ inches, across from the back seam, and draw the oblique or measuring line in front through those two points (see $\mathrm{F}$ and $\mathrm{G}$ in the Plate). Your attention will now be directed to the point $\mathrm{E}$, a most essential point, and its precise situation is thus determined : by placing the back in the upright position at $C$ and $D$, and from the top of back seam as a centre cast the dotted curve by the waist length (or 19 inches), being also 6 inches (or full one-third of breast) from the back seam when closed at the hollow of waist; again, while the back is in the upright position, let $\mathrm{E}$ be your centre position, and extend your measure (or compasses) to the top of back seam, and cast the dotted circular line to the front, crossing the whole figure, and terminating at the measuring line; this, it will be seen, gives you the elevation, or height, of the forepart.

"The next point which demands your attention is at $H$, on the line of measure in front, and observe that from this point, as a centre, is to be cast the arc or curve, extending from the top of the standard back scye, intersecting the circular line at $K$, and terminating at the measuring line in front at $L$, thus 
forming the shoulder line of forepart. But before we proceed further it will be necessary to explain how the point $H$ is to be obtained, as it is in a position which is not fixed, but is determined by the proportionate length of waist taken from the intersection at I, down along the measure line in front; and observe, whenever the waist length exceeds the breast width (as in the example before us), the back must be placed in the closing position at the side seam. But, on the contrary, when the breast width is equal to, or exceeds the waist length, then it will be seen that the same position would inevitably cast the shoulder line too high; you will therefore, in the latter case, place the back in the upright position at the side, and from the point $\mathrm{H}$ extend to the top of the back scye, and cast the shoulder line as already described. But to proceed.

"Having determined the precise situation for the shoulder point of forepart, as at $\mathbf{K}$, your attention will now be directed to the neck, or foregorge, which is to be cast by the fourth of breast (or $4 \frac{1}{2}$ inches) from the angle at $\mathrm{L}$, which, when correctly drawn, is exactly the fourth of breast from the shoulder point. Next mark the length of shoulder seam by placing the standard back in the closing position on the shoulder line from $\mathrm{K}$; mark also the front of the scye by taking two-thirds of breast from the back seam (while in the closing position at the side) in the direction of the lower part of the foregorge; the remaining third is the due proportion for the breast of forepart, all above which may be rounded off, as an allowance for the falling of the breast, and is accounted for by the buttons being thrown as much farther back in proportion, or the piece may be taken out, if that is preferred.

"The scye is the next object which demands your attention, and may be scientifically formed. It may be cast thus: by marking 9 inches (half breast) on the line from back seam to front of neck, as a centre, and cast the front part of scye by 3 inches (or sixth of breast), and the remainder from a centre to be found equi-distant from those points respectively. In practical application, however, the shortest method is most desirable, and, after obtaining the three essential points above mentioned, very little experience will be required to guide the judgment sufficiently near for every useful purpose, especially if to the above three points be added a fourth; thus, from the back seam (in the closing position at the shoulder) take 12 inches (being two-thirds of breast) downwards, and this will give you the bottom of the scye, or fourth point.

"You will find the proportionate length of lapel by making $K$ at the shoulder point your casting position, from which extend downwards to the standard hip of forepart, and cast across to where it falls on the measuring line in front; but, when the 
lapel is required to be either longer or shorter, take a measure for that purpose ; thus, from the top of back seam to the length required in front, and observe, when you square the bottom of lapel, take care to draw the line in an oblique direction, as in the Plate, for if drawn horizontally, or straight across, your points in front will hang too low when the coat is buttoned.

"The line for the front of lapel, with the breadths and form of the front of the skirt, must be regulated either by your own taste or the prevalence of fashion and custom in those cases respectively."

Before proceeding with the Breeches, Pantaloons, and Trousers Systems of Mr. Golding, it will be more convenient and appropriate to notice the Coat System. The first thing interesting to remark in this method is, that it is formed by a compound of depth and width. The width is obtained from the circumference of the chest, and the depth from the proportionate waist, which is got by measuring from the centre of the back to the elbow. From these two quantities the subdivisions are obtained. Some of the subdivisions are similar to those known as the old thirds. On the back we have an important point $G$ fixed at one half the waist length, the principal point for sweeping the shoulder is fixed at $\frac{1}{3}$ rd breast from the waist, the front of the scye at $\frac{2}{3} \mathrm{rds}$, and the remaining third gives the distance to the chest line, and also $\frac{2}{3}$ rds are given as the proportion necessary from the back seam to the bottom of the scye.

In the formation of this system, a glimmering of the truth that widths must govern width, and depths regulate depth, is perceptible in the mind of the author. And if the sciences of anatomy and geometry are but incidentally used, a knowledge of their importance and connection with our craft was evident to the mind of the author. It is certainly creditable to the intelligence of our predecessors that they should have at the outset remarked their intimate relation with and the dependency of our profession on those sciences. That they had not sufficient knowledge of these subjects, and consequently were not able to apply them, is not to be wondered at.

If this method is imperfect, as it undoubtedly is, the obtaining of the most important position of the shoulder neck point and the shoulder seam by such complex and unreliable means proves it; still it must be remembered that this is one of the earliest systems, and is a great advance on that published by the Society of Adepts in 1796.

The coat was cut direct from the cloth according to the directions given. The economy of using paper patterns was not yet perceived. Neither was the square used, as we have no directions for its use, the points being obtained by casting. 
These castings, as they were called, seem now very complex and unsatisfactory, while the loss of time incurred in forming the scye, instead of simply chalking it, is unaccountable.

All coats seem to have been formed without a waist seam, except the Wellington Frock, which is doubly interesting, as showing the introduction of the frock coat and the rudiments of the waist seam to coats, which now seems to us indispensable to produce form in our garments.

As we have seen the kind of method the tailors of this period had to assist them in producing garments, it will probably be curious and instructive to refer to illustrations of the costumes of that period, as shown on Figs. 3, 4, Plate 1.

On first glancing at these illustrations of fashion a little more than half a century ago, we feel amused and surprised at our predecessors' notions of grace and elegance. The collar of the great-coat much resembles a horse collar, the hollow curved lapels, the skimpiness of the waist, the amplitude of the skirts, the extreme fulness of the tops of the sleeves, which is compensated by the narrowness at the hand, added to a superabundance of neck-cloth, combine to make a man appear to us as a figure of fun, more fit for ridicule than imitation.

The evening dress is not so absurd, although the dress coat and neck-tie combine all those sins against comfort and good taste which prevail in the great coat; yet the dress breeches, silk stockings, and shoes give an air of lightness and elegance which compensates in some measure for the monstrosity of the dress coat. Compare these figures with the illustrations of our present fashions, and although there may be still great room for improvement, there can be no question which style is the more elegant, and more in consonance with the principles of good taste and adaptability.

\section{ON Cutting BReeches, Dia. 2, Plate 6.}

"Let the straight line A A, Dia. 2, be considered the edge of the cloth-first then place the end of your measure to within half an inch (being an allowance for making up) of the edge at top, on that line as at $\mathrm{B}$, and (extending the measure downwards) mark the several lengths to the bottom, as shewn in the Plate, thus-from $\mathrm{B}$ at the top, to $\mathrm{C}$ at the hip; 3 inches, continued to the bottom of knee-cap at K, $23 \frac{1}{2}$, ditto to small below the knee at $\mathrm{H}, 25 \frac{1}{2}$, and to full length required, say 28 inches, to which will be added (you know) the knee-band, and which may be considered a sufficient allowance for making up; next draw the straight line $\mathrm{P} P$, parallel with the line $\mathrm{A} A$, at the distance therefrom of half the waist measure, which in this example is 8 inches; and then mark the balancing point D, 
about 8 inches from the top, in the centre between those two lines, and from that position balance the several lengths across from the line A A, except when cutting dress breeches, or such as do not come much below the knees, in which case it will be proper to balance from point $\mathrm{L}$, about 4 inches lower; as breeches of this sort require to be cut more round at the bottom of the forepart to prevent them riding up at the knee; the ham also will require to be somewhat more hollowed than those breeches which are cut to the calf. The length of thigh from hip to knee is $20 \frac{1}{2}$ inches; divide this length then into 4 equal parts, and mark one-fourth of it down from the hip, as at $E$; next mark by your measure the size of the calf, the small below knee, and also the hollow just above knee-cap. Your next object is to determine the just elevation of the crutch, or fork point; and this is what has so much perplexed the cutters of the old school to obtain, having no science or settled system to guide them.

"Proceed then to mark the point in the centre of the small below the knee, and let that be your position from which to extend your measure (or compasses) obliquely upwards to the point $\mathbf{E}$, and cast across the dotted curve $\mathrm{E} \mathrm{F}$, crossing the parallel line P P, thus you have the elevation or height of the crutch; now measure 4 inches (being one-fourth of waist) from the point of intersection (or where the lines cross at I) along the curve line to $\mathrm{F}$, and this determines the extension or width of the crutch.

"Having settled (I trust to the satisfaction of my readers) this very essential point, I shall proceed to define in a scientific though simple manner, my method of hollowing the crutch or (as it is called by the trade) the fork seam, and this may be done by a part or portion of a circle, the centre of which is 4 inches from the point $\mathbf{F}$, and 5 ditto from the parallel line (which is an allowance of an inch for the hollowing at the side seam), and prevents the fall-down seam from being too hollow above the curved line, and which is a very capital though common fault; from the point $G$ then cast so much of a circle as your purpose requires, and continue the line upwards to the top of the fall-down, taking the diagram for your guide.

"Draw next your leg seam, by straight line from point $F$; down to the measure just above knee ; but I would here observe, that as this line or edge is in an oblique direction (or technically upon bias), it is therefore (from elasticity) liable to stretch or be unsteady, by being drawn lengthways; it may therefore be advisable to take out a small hollowing (say $\frac{1}{4}$ of an inch at most in the middle) gradually reduced to the points top and bottom; by this means your leg seam will become straight and perfectly steady when the breeches are on; the remainder of 
the leg seam you will complete by passing the points of measure, recollecting the projection, or swell of the knee, especially of muscular or bony men; see diagram.

"The side seam now demands your attention, for when breeches are required to fit close and neat, it will be requisite that you hollow the side seam; this you will do by commencing at the hip, point C, passing your top width measure point $10 \frac{1}{2}$ (taken from the leg seam about an inch down from the crutch) gradually returning to the straight line at $K$, observing that swell or roundness about the middle of the thigh which some men possess, and shape your line accordingly. Fashion or fancy will sometimes require the buttons to be brought high, or forward, on the knee; this may be effected two ways, first, by drawing the line straight from the extreme hollow of the side, down to the bottom, and (of course) adding to the inside, or hind part, whatever you reduce or take from the front or forepart; secondly, by reducing the forepart from the knee only, gradually from the point $K$ to the bottom, adding (as before) both the quantum and shape to the hindpart; by the former method it will be seen that the whole side seam is thrown higher, or more on the top of the thigh, but the edge being straight, may better suit cords, ribbed, or any kind of stripes; while the latter, by preserving the side seam in its regular course, may be preferred for Kerseymere, \&c., or anything of a plain surface, by thus keeping the seam more out of sight.

"The hindpart, or by some called the inside, is next to be delineated; on examining the Plate you will observe that the crutch point of the hindpart has an allowance of about half an inch, both in height and width beyond the point of the forepart; the reason for this is, that by stretching the forepart to meet it when sewing the leg seam, it not only gives ease and freedom to the wearer, but is also a means of preventing those wrinkles or creases sometimes observable.

"Place now your measure (or compasses) at the crutch point of hindpart and extend upwards obliquely, in the direction of the top of forepart at B, and cast so much of a circle as you require for completing the length of waistband, and no more; for when breeches are cut so much above the hip, fulness in waistband is worse than useless; the length required on the circular line in this example is 8 inches-measure, therefore, 8 inches from the point $\mathrm{B}$, on that line, and this is the full height of your seat-unless your breeches are required to be shorter from the hips upwards, in which case the seat may be cast an inch or so higher than the rule; on the contrary, when they are ordered much higher from the hip (say 4 to 6 inches), you may then cut the seat lower than the rule by an inch or so-but to proceed, draw the line from top of seat downwards, 
in the direction of the crutch point of hindpart; it may be drawn nearly straight from the top gradually extending to a round, or curved shape about the middle (subject however to your own observations of the person when measured), and then progressively reduced to a straight line, as shewn in the plate. The knee, or bottom of breeches cut to the calf, will require a little careful management, with a view to their well fitting, and this will principally depend upon the making up; it may be well however to cut the hindpart about the third of an inch shorter than the forepart, and then let the hindpart be well stretched about the hollow below knee to its proper length; this will give ease and freedom to the knee, and also improve the fitting in the ham. The knee-band is to be cut to measure, and the bottom of the hindpart (after being a little hollowed) is to be stretched to receive it. Be careful not to fall into that most egregious of all errors, namely, the placing your waistbands too backward, as that frequently destroys the fitting of well cut breeches. Your waistbands ought to be at least the third of an inch forwarder than the fall-down seam."

\section{Pantaloons, Dia, 1, Plate 6.}

"This is an article of dress very generally worn, and when made to fit well, are exceedingly neat and convenient, as they may be worn either with gaiters, boots, or over the stockings only.

"The top, or upper part, is formed in the same manner as breeches, it therefore need not be repeated; but we will pass on to that part of the subject, below the knee, as shown in Dia. 1, Plate 6 , where you find the measure of lengths continued from the knee (being $23 \frac{1}{2}$ inches) to small $25 \frac{1}{2}$ to the fullest part of calf 30 , and to the bottom 38 inches. Balance your length across, therefore, from the centre of the forepart, as before, proceeding from the side, or edge of the stuff, determining your several widths according to measure; the side seam to be hollowed as before premised, and the side at bottom may be taken at half the difference between the measure of calf and ankle, being in this example $1 \frac{1}{2}$ inches from the straight edge. The slit or opening at the bottom will require your attention, particularly when cutting for a slender figure, in which case the aperture will require to be longer, to admit the draught of the foot between the instep and heel to pass freely-but it will admit of being shortened in proportion to your increase of width, which is very obvious, the heel and instep passing through obliquely.

"The observation made in the breeches, recommending the hindpart to be stretched to the ham, is peculiarly applicable to Pantaloons, for, from their being confined so much below the knee, 
they require all the advantage that can be derived from that circumstance; let the hindpart be cut, therefore, half an inch shorter than the forepart, and be well stretched in the ham with an iron, both at the leg seam and side-recollect also, when you are cutting for a thin, bony person, that you make a proportionate allowance for the projection of the knee-bone, particularly at the leg seam of forepart."

\section{Pantaloon trousers, Dia. 1, Plate 6.}

"This is one of those articles of dress, devised by fashion, and wherein the human shape is altogether unconcerned. I shall therefore briefly describe the method of forming them, and refer the reader to the engraving for the shape, \&c.

"As they are the same upwards as Pantaloons, I shall commence my observations at the calf, by remarking that they are usually cut the same width at the bottom as at the calf, and may therefore be cut to the same measure from the straight line at the side; the bottom is sometimes cut square across, at other times the forepart is cut hollow, and the hindpart round; the point at $\mathrm{P}$ is a centre position, from which to cast the convex, or round form of the hindpart, and which by being reversed, will produce the concave, or hollow form of the forepart-and observe, the greater your balancing distance, the more flat will be your round and hollow, and vice versa; when made with loops, or buttons, at the side, as shewn in the Plate, they then receive another name, and are called WeLLINGTON's from the circumstance (no doubt) of their being first worn by the Military."

\section{moschettos, Dia. 3, Plate 6.}

"These are not so generally worn now as formerly, but when worn upon a well-turned figure, and made with skill, have a remarkably genteel appearance; the several measures of length may be taken as before, down to the calf, and continued to smallest part of leg, say 40 inches, and to bottom (about an inch over shoe) 44 inches.

"An additional measure will also be required in this case, namely (obliquely), from the centre of the hollow of instep, down about an inch below the top of the heel of the shoe, this with a view to ascertain what spring will be requisite for the heel behind, to give ease and freedom over the shoe.

"It may also assist the juvenile cutter to measure the breadth of the foot over the thickest part, about an inch below the shoe on each side, this will be a guide to the size of the flap or tongue which will be required.

"This garment is the same as pantaloons, so low as the small 
Plate 6.

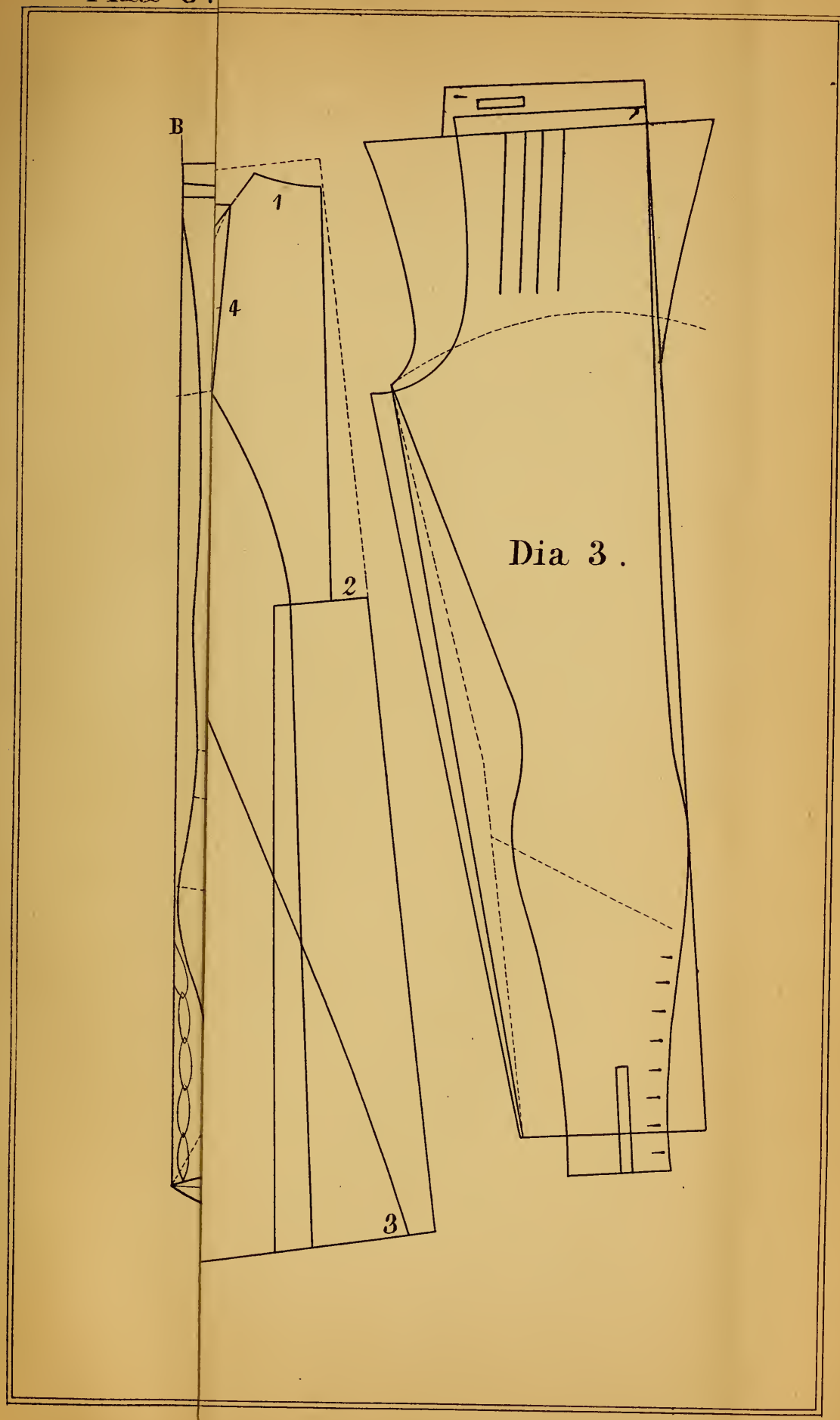




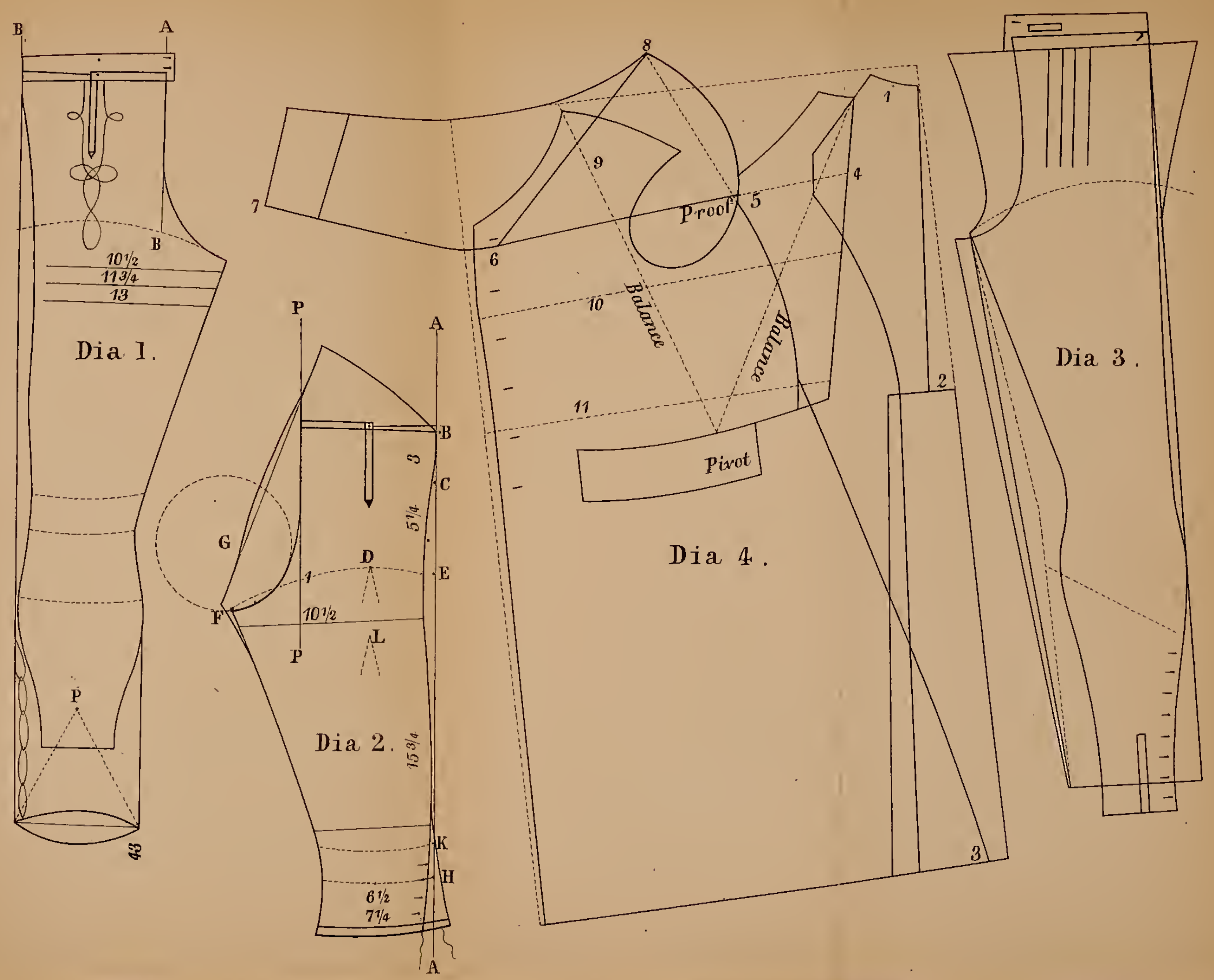



of the leg, which may be continued in nearly a straight line to the bottom, allowing, however, a trifling spring from where it comes over the top of the shoe; the buttoning at the side is to be regulated by the same rules (as premised in pantaloons) to allow the heel and instep to pass freely, see the dotted oblique line; when the forepart is cut exactly to measure, you may cut the slit, or incision, for the tongue, exactly in the centre of the forepart, and from 4 to $4 \frac{1}{2}$ inches in length, according to the size of the foot, and be careful in cutting the hindpart low enough at the heel, to prevent its riding up above the shoe, which is a great fault, though frequently to be met with."

\section{COSSACKS, Dia. 3, Plate 6.}

"Cossack Trowsers have lately been very fashionable, and although they cannot lay much claim to elegance, may yet. please from their novelty.

"Notwithstanding the rude shapelessness of this garment, it will be necessary in measuring that you take the three principal lengths, namely, the hip, knee, and bottom; also the waistband, and that is all you need take; the casting point at the knee may generally be taken at about 3 inches from the edges at the side; and the Os Coccygis (so called by anatomists) or technically by the trade the fork point, is frequently thrown an inch forwarder than the rule, the thigh frequently measuring 12 or 13 inches across the top. The top of the front of the forepart may be cut from 12 to 15 inches wide, and when cut to an extreme, ought not to be all in front but proportionally at the top of the side-see the Plate.

"The extra width is to be plaited or gathered into a band, or top welt, across the front, and they are best made with a whole flap; the fulness, or plaiting, is shewn in the engraving by those short parallel lines drawn from the top; the lower part is very wide and loose, with a ribband to draw round the bottom.

"Recollect that you cast the circular line (for the top of the hindpart) from the real, or proportionate crutch point, for it is evident, if you were to cast from any position wider than this, it would throw the seat so much higher in proportion to its width, for whatever change takes place at the centre must of course produce a corresponding alteration at the circumference.

"The Sailor's Trowsers (or as called by them the gun-mouth'd trowsers) are cut in the usual manner upwards; and from the crutch downwards, resemble the Cossacks, being, perhaps, yet wider at the bottom, the length of the foot being a rule for the half width; but no drawing ribband for Jack!

"The common plain trowsers are somewhat like the last, but not so wide, and are sometimes hollowed principally about the 
bend of the knee; see the dotted line from the crutch to the bottom in the Plate."

It is very evident, from the prominence given to the Method of Cutting Breeches by our author, that they were the fashionable nether garment of the period. We are also introduced to the knowledge of the existence of various forms of garments whose names only exist in the dead past. But who shall say that they will not be revived, and blossom forth as new fashions, or novel inventions, in the not distant future? The modern form of trousers seems to have been gradually developed, and not invented. First we have the breeches, pure and simple; these are prolonged to the ankles, and they become pantaloons. A slit is made in the centre of the top side of the pantaloons, about $4 \frac{1}{2}$ inches in length, and a gaiter tongue inserted, forming a combination of pantaloon and gaiters; these 'were called Moschettos. Another form was produced by continuing the pantaloons to the full length of the leg, making them the same width at bottom as at the calf, and then calling them pantaloon trousers. The military, it appears, adopted this form, only fastening them from the calf downwards, with loops or buttons; they were then called Wellingtons. Besides these there were the Cossacks, or plaited trousers, such as we now make for dressing trousers only; and the Sailors, or gunmouthed trousers, cut full as at the present time. The common plain trousers, we are told, are "somewhat like the last but not so wide, and are sometimes hollowed, principally about the bend of the knee." By this very curt description they could have been very little worn, and of very little importance, or else they would have received more attention, and required a fuller description.

The Breeches System is very simple and crude. The manner of obtaining the length of the leg seam by a definite quantity of three inches and one-fourth of the measure from hip to knee, seems very faulty. The width of top side and the size of fork, are obtained from divisions of the waist measure. The curve of the fork is got by sweeping, a practice quite abandoned by modern cutters. The system produces a close fitting breeches about the hips and thighs. The cut is open, with a large fork, and a straight seat. It is well to remember that these characteristics prevail among the breeches makers of the present day. This class of breeches are what we should call full or even foul at the fork, and custorners will submit to wear riding breeches cut by these gentlemen, that they would not endure from ordinary tailors. Breeches makers assert (and quite right from their style of cut) that this length, or rather width of fork, must exist or else there would not be sufficient room in the breeches when in the saddle. The straight seat 
gives a shortness and cleanness of seat, while the width of fork must provide some of the extra length required by the wearer when in that position.

Taking the works of Mr. Golding, as a whole, I think we may agree there was considerable merit in the productions. That there were serious defects in the construction of his system there can be little doubt, but that they were improvements on such works as those issued by the Society of Adepts, there can be equal positiveness. I feel confident that Mr. Golding will rank as one of our honoured predecessors, and his name merit the grateful remembrance of the trade.

\section{MINISTER'S SYSTEM.}

One of the best known and most honoured names in connection with the history of our craft is that of Mr. Edward Minister. It is scarcely credible that the author of a new and complete System of the Art of Cutting, published in 1820, was still living in 1885 ; and, although physically weak from his advanced years, is apparently as in full possession of his mental faculties in his ripened years as he was in his early manhood.

Mr. Minister states, and there is no reason for doubting the perfect accuracy of his statement, that his system is original. When he arranged his original method, the systems in use by cutters were very few and very imperfect. Seeing this, and having acquired some knowledge of geometry when he was at school, he applied his knowledge and experience to the construction of a system, which he contends was superior to those in use at that period.

The most noteworthy feature of this system is the introduction of the principle of the square for drafting purposes. This principle is one which distinguishes and characterises the various changes and improvements on the original method, which time, changes in fashion, and ripened judgment have dictated. The old practice of casting the shortest curves instead of drafting them by free hand prevails in this system, thereby making the outlines rigid and uniform, instead of allowing freedom for the exercise of taste.

Following the plan I have laid down, I shall give the opportunity to the author to speak for himself, and his diagrams to illustrate his meaning, so that intelligent readers may by comparison form a sound judgment of its merits.

"To form the Back (Dia. 4, Plate 7.)-Suppose A the bottom of the cloth, and A, C, B, the double edge (observing the wool to run to bottom of the back), from $A$ to $B$ is the length of the coat, and from $\mathrm{B}$ to $\mathrm{C}$ the length of the waist. ing.

"Mark from C to D, one-twelfth of breast for back hollow- 
"Draw a line from $\mathrm{D}$ to $\mathrm{B}$, and continue to $\mathrm{E}$, $\mathrm{E}$ being onehalf the breast measure from $B$.

"Make a centre at $\mathrm{E}$, and cast the top of the back from B to $\mathrm{F}$.

"Mark from B to $\mathrm{F}$ any width you please; mark from $\mathrm{B}$ to $\mathrm{G}$ one-third of the breast, and draw a line square with the back seam to $\mathrm{H}$, for the top of the side seam.

"Mark the width of the back from $\mathrm{G}$ to $\mathrm{H}$ any width you please; and so from $\mathrm{H}$ to $\mathrm{I}$, for the length of the back scye; and from $\mathrm{D}$ to $\mathrm{J}$, for the width at the bottom of the waist.

"Draw a line from $\boldsymbol{J}$ for the plait, and allow one inch and one quarter parallel with $\mathbf{J}$ to go under the plait.

"To form the Forepart (Dia. 5, Plate 7.)-Suppose L to be the bottom of the cloth, take the length of the back skirt from $J$, and mark the same from $\mathrm{L}$ to $\mathrm{M}$.

"Mark from $\mathrm{M}$ to $\mathrm{N}$ one-eighth of the breast; mark from $\mathrm{N}$ to $\mathrm{O}$ the length of the side seam, and draw a line from $\mathrm{N}$ to $\mathrm{O}$.

"Mark on the back from $\mathrm{P}$ to $\mathrm{Q}$ one-third of the breast, from $\mathrm{P}$ to $\mathrm{R}$ one-half; and from $\mathrm{R}$ to $\mathrm{S}$ one-fourth (or threefourths from $\mathrm{P}$ to $\mathrm{S}$, which will be the same as one-fourth from $R$ to $S, R$ being one-half from $P$ ).

"Close the back on the line drawn from $\mathrm{O}$ to $\mathrm{N}$, the top of the side seam to $\mathrm{O}$, and opposite $\mathrm{S}$.

"Place the square in a line with the back seam, making the length from $\mathrm{S}$ to $\mathrm{T}$ the bigness of the breast; and mark from $\mathrm{T}$ to $\mathrm{U}$ one-half the breast, allowing one-quarter of an inch for the back seam, $\mathrm{U}$ and $\mathrm{T}$ being square with the back seam.

"Place the corner of the square at $U$ in a line with $R$, and mark from $\mathrm{U}$ to $\mathrm{V}$ the same as from $\mathrm{T}$ to $\mathrm{U}$, that is, half the breast and a seam.

"Mark from V to W, one-fourth of the breast, and from W to $\mathrm{X}$, one-fourth of the breast square with $\mathrm{V}$ and $\mathrm{W}$.

"Draw a line from $\mathrm{Q}$ to $\mathrm{X}$, which will be the exact bigness of the breast. (This will be invariably the result of the system, if the proportions have been correctly taken).

"Mark from $Q$ to $Y$, half the bigness of the breast, for the centre of the scye, and $\mathrm{Q}$ to $\mathrm{Z}$, two-thirds of the breast, for the front of the scye.

"Cast the scye from $\mathrm{Z}$ to the top of the side seam, making a centre at $\mathrm{Y}$.

"Cast the neck from $\mathrm{V}$ to $\mathrm{X}$, making a centre at $\mathrm{W}$, which casts a military neck.

"To ascertain where the shoulder seam should be placed, place the top of the back at V, and lay the back seam in a line with $\mathrm{U}$; and wherever the shoulder seam of the back falls, the shoulder seam of the forepart must meet it, which renders it 
quite immaterial what width the back is cut, length of the back scye, or width at top of back.

"Mark from V to 4, one-eighth of the breast, and draw a line from 4 to $\mathrm{Y}$; continue to the bottom of the skirt; and parallel with that, from the waist, will give the proper spring for the skirt.

"Take the bigness of the breast at 5 , and the waist at 6 , and shape the front to the front of the neck, and bottom of the lapell."

The illustrations I have given show that when this system was published, coats were not cut across the waist. As time progressed, various changes took place in the style of dress, and Mr. Minister published certain improvements on his original system to meet the different requirements. In one of his treatises he claims that he embodied three entirely original principles in the art of cutting, viz., firstly, "the use of the square for finding the balance; secondly, the plan of finding a line on which to place the back when closed at the shoulder, so as to render the shape of back entirely optional ; and thirdly, the method of producing the forepart and skirt together."

In the year 1847, Mr. Minister, in conjunction with his son, Mr. George Minister, published his principal work, "The Complete Guide to Practical Cutting." It was issued in eight parts or two volumes. The work contains systems for cutting all styles of coats, as well as uniforms and liveries, breeches and gaiters, trousers and vests, and ladies' riding habits. Besides, it contains articles on making up and disproportion, and a concise theory of alterations. The method is what is known as a breast measure system, that is to say, the various points are found by proportions of the breast measure. In later editions, however, Messrs. Minister, yielding to the teachings of experience, have cut their corpulent men's coats by divisions of a scale proportionate to the front of scye measure. They found by experience that a corpulent man's coat, when cut by proportions of his breast measure, produced a coat too large behind, and consequently too small in front, and they have thus given the results of their ripened experience for the benefit of their students. The system is simple in use, easily acquired, and extensively used by those who prefer the breast measure as a principle of cutting.

A comparison of the first system with the last is very instructive, as it shows the great advance which has been made in systematic cutting, and this is brought more forcibly before our minds, as they are both, broadly speaking, the productions of the same author.

I understand that Messrs. Minister and Son claim the credit of being the original introducers of the central line as a basis 
for the construction of trousers. This claim I have every reason to believe is most justly made, and has never to my knowledge been either questioned or disputed. That alone would make them worthy of our grateful remembrance. I have introduced their trousers system here, because their works may be more conveniently considered together. This system was published in 1847 .

Minister's Trousers System (Dia. 4, Plate 9).-The measures are $2,26,43,15(18), 7 \frac{1}{4}, 8 \frac{1}{2}, 32$. Draw the line A B, which we term the plumb line; make a line across at $\mathrm{C}$ for the top of the upper side. Mark from $\mathrm{C}$ to $\mathrm{D}$ the length from the top to the hollow of waist (2); continue to $\mathrm{E}$ for the length of the knee-bone (26); and to B the full length of side seam (43). Mark up from B to $F$ the length of the leg seam (32), less one seam. Draw the line $\mathrm{G} H$ across at $F$. Mark from $F$ to $G$ one-fourth seat measure $\left(4 \frac{1}{2}\right)$, and from $\mathrm{G}$ to $\mathrm{H}$ two-thirds of the seat measure (12); from $\mathrm{F}$ to $\mathrm{I}$, half of $\mathrm{F} \mathrm{H}\left(3 \frac{3}{4}\right)$. Mark from $\mathrm{D}$ to $\mathrm{K}$ one-fourth of the waist measure $\left(3 \frac{3}{4}\right)$, and draw the line from $\mathrm{K}$ to $\mathrm{I}$. To find the fork, mark from I to $\mathrm{L} 13$. inch, and shape the fall seam through this point to $H$. From $D$ to $M$ mark one-fourth of the waist measure ( $\left.3 \frac{3}{4}\right)$, and to $N$ one-eighth of the waist measure from M. Form the upper part of the side seams both of the top and under sides, bringing each to the point $G$, and springing them out gradually at top above the hollow of the waist. Mark from $\mathrm{C}$ upwards on the plumb-line one-fourth $\left(4 \frac{1}{2}\right)$, and then form the top of the under side from the side seam intercepting this point. Try the size of the waist to $\mathrm{O}$, allowing half an inch for the side seams, and form the seat seam as diagram, by drawing a straight line from $\mathrm{O}$ to $\mathrm{H}$, hollowing it a little opposite the point $\mathrm{L}$, and carrying it out three-quarters of an inch beyond the point of fork. This completes the upper part of the trousers. Mark from $\mathrm{E}$ to $\mathrm{P}$ three-quarters of an inch more than half the measure of the knee-bone, and from $\mathrm{P}$ to $\mathrm{Q}$ whatever width is intended. To determine the correct position of the bottom of the leg seam, mark from $B$ to $R$ one inch less than half the size ( $\left.3 \frac{1}{4}\right)$, and the remainder from $B$ to $S$. The distance from $B$ to $R$ is $3 \frac{1}{4}$ inches, and from B to S $5 \frac{1}{4}$, making $8 \frac{1}{2}$ inches. Form the leg seam by the points $\mathrm{H}, \mathrm{P}$, and $\mathrm{R}$, and complete the side seam from $\mathrm{G}$ through $\mathrm{Q}$ to $\mathrm{S}$.

\section{WYATT'S SYSTEM.}

One cannot but regard with surprise and satisfaction the evident progress that has been made in our profession during the last fifty years. What was then the height of fashion, we now look upon as an absurdity; what was then sufficient for the 
purposes of the cutter, would now be lamentably insufficient. If little was required, certainly little was given, for the information afforded is very meagre compared with what is promised by the title pages of our old authors.

A second edition, corrected, enlarged and improved, of the "Tailors' Friendly Instructor," was published by J. Wyatt, in 1822. It purported to be " an easy guide for finding the leading and principal points essential to the art of fitting the human shape, \&c., designed on the principles of practical geometry," \&c. Of geometry, there is more in the title than in any other part, for beyond the fact that a portion of a paragraph is devoted to showing that circles, or rather segments of circles, may be drawn from different centres, geometry is conspicuous by its absence. It is somewhat strange to find the author saying "he has made several valuable improvements by the aid of the square," an instrument whose introduction he attributes to Mr. Read; it was once considered by many to be an unnecessary appendage to the cutting board, and he adds, "Mr. Hearn suspended a square over his cutting board by way of derision to the person who used it." At the present time it is scarcely conceivable how cutters could have proceeded without the use of such a simple, useful, and invaluable aid to systematic cutting as the square. But it was an innovation on old customs, and as such was first despised, then ridiculed, and lastly adopted, when everybody wonders why its use was not discovered long before.

It would appear that the inch measure was not yet in general use, for the writer says, "It is immaterial whether a person measures by inches or a parchment measure, the snips on one designate the different lengths and widths, the same as the number of inches on the other, and each requires the same proportions."

Our author has thought it necessary to disfigure his pages with adverse remarks on Mr. Hearn's system. Posterity will conclude that he and others had better left it to judge of their comparative and respective merits.

"Method of forming the Back (Dia. 1, Plate 7.) - The line A represents the double edge of the cloth, the length of the coat is 36 inches, and the waist 16 inches; place 36 inches at the bottom $\mathrm{A}$, and extend the measure to the waist 16 inches, and make a point $1 \frac{1}{2}$ inch within the edge, as at $\mathrm{D}$; then measure the length of waist from $\mathrm{D}$ to $\mathrm{C}$; next place the angle of the square at $\mathrm{D}$, and draw the back seam line to $\mathrm{C}$; while the rule is in that position mark the bottom at the side seam oneeighth of breast measure $2 \frac{1}{4}$ inches, then place the angle of the square at $\mathrm{C}$, and mark the width at top one-eighth of breast measure, observe the top of shoulder seam is marked above the 
square, as one side of it lays along the back seam; then place the angle of the square 6 inches from the top $C$, and draw a line acruss the width of back one-third of breast measure, 6 inches; that determines the top of side seam; then mark the length of back scye one-eighth of breast measure. Having thus found the points, the shape of the seams may be found by circular lines from different centres; mark the skirt the same width at bottom as at top, and allow as much for the plait as your fancy may suggest, then draw the plait line, and the form of the back is complete.

"Method of forming the Forepart (Dia. 2, Plate 7).-The line $\mathrm{B} B$ represents the selvedge edge of the cloth, but before you begin to mark the forepart, draw a line down the back seam from the top to the bottom $\mathrm{E}$, and put a mark 6 inches from the top. If you intend to mark the forepart at the top of the cloth, place the back so as the line $\mathrm{E}$ may be 3 inches from the edge, as from $\mathrm{E}$ to $\mathrm{F}$. Observe the back lays smooth upon the board, in such a position as will enable you to draw a line square with the back seam, the length of three-fourths of the breast measure, $13 \frac{1}{2}$ inches, before it goes off the cloth, that will prevent your cutting cloth to waste at the top of the shoulder seam; but this line must be continued the length of the breast measure 18 inches, as from the top of back seam to $\mathrm{G}$, then draw the front line from $\mathrm{G}$ to $\mathrm{H}$, that produces a square the size of the breast. To form the different points of the forepart by the square, proceed as follows: first mark 4 inches from the front angle $G$ to $I$, that is half an inch less than one-fourth of breast measure, then mark one-eighth of breast measure, $2 \frac{1}{4}$ inches, from I to $\mathrm{K}$; next place the angle of the square rule at the mark 0 inches from the top of the back seam, and draw a line from 6 to $\mathrm{L} 11 \frac{1}{2}$ inches, that is, half an inch less than two-thirds of breast measure; then mark on that line half the distance between the bottom of back scye and $\mathrm{L}$ at the front of forepart scye, then from that point mark one-eighth of breast measure down to $\mathrm{M}$, and from $\mathrm{M}$ to $\mathrm{N} 2 \frac{3}{4}$ inches, that is half the distance between the back scye and $\mathrm{L}$; then from point $\mathrm{N}$, as a centre, cast the lower part of scye from the top of side seam to L. The next point to be observed is $\mathrm{O}$; to get that point exact, mark the distance from $\mathrm{M}$ to $\mathrm{P}$ $8 \frac{1}{4}$ inches, and from $\mathrm{P}$ to $\mathrm{O} 4 \frac{1}{4}$ inches, which makes the distance from $\mathrm{M}$ to $\mathrm{O} 12 \frac{1}{2}$ inches, that is half an inch more than two-thirds of breast measure; to take the width from $\mathrm{P}$ to $\mathrm{O}$ correctly, place $4 \frac{1}{4}$ inches on one side of the square rule at $\mathrm{P}$, and let the other side touch the point $K$, then mark the point $\mathrm{O}$ at the angle of the square, and draw a line from $\mathrm{O}$ to $\mathrm{K}$, then make $G$ the centre, and form a quarter of a circle from I to $\mathrm{Q}$. The next object that requires your attention is the 
Plate 7.

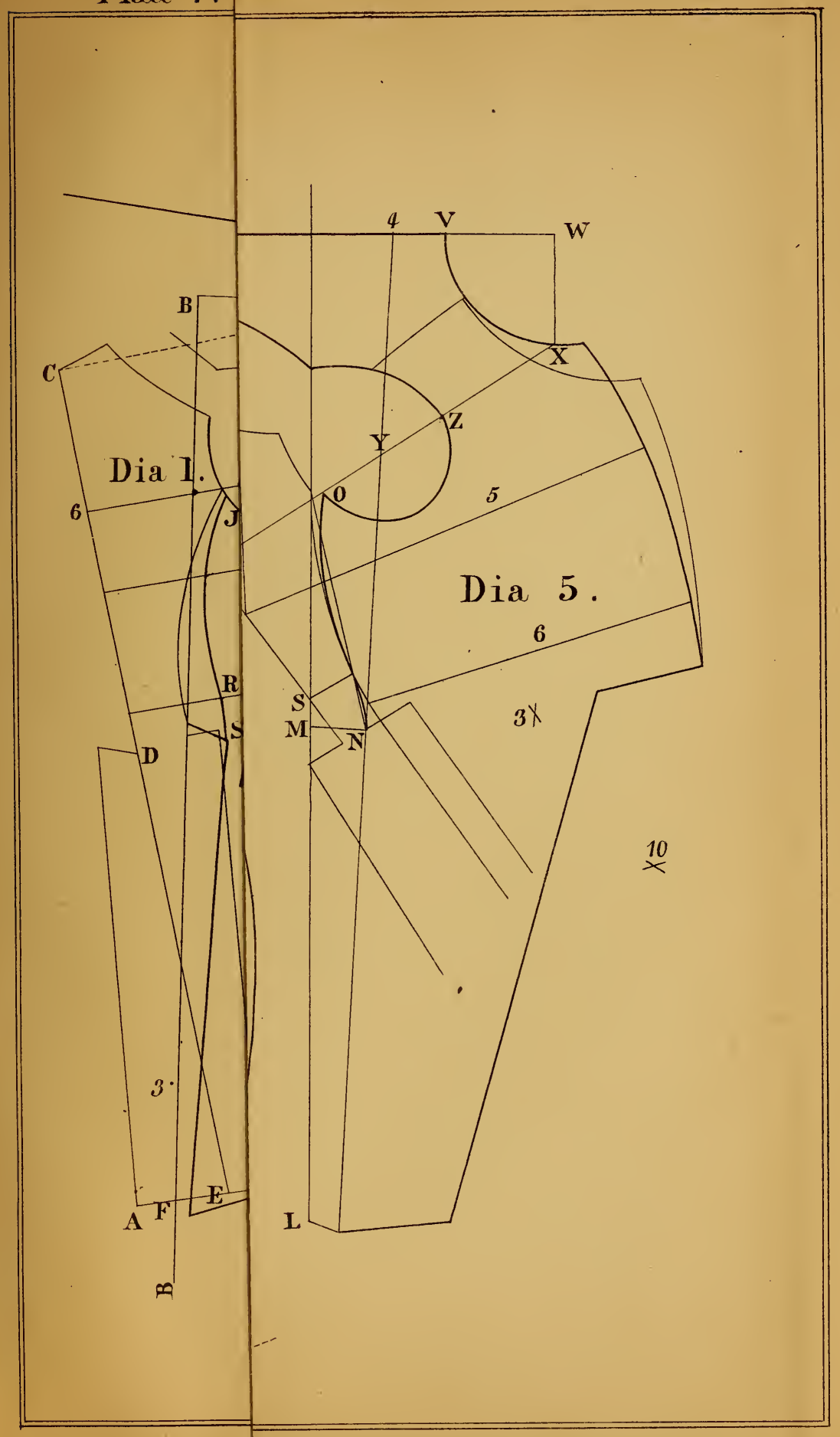




\section{Plate 7.}

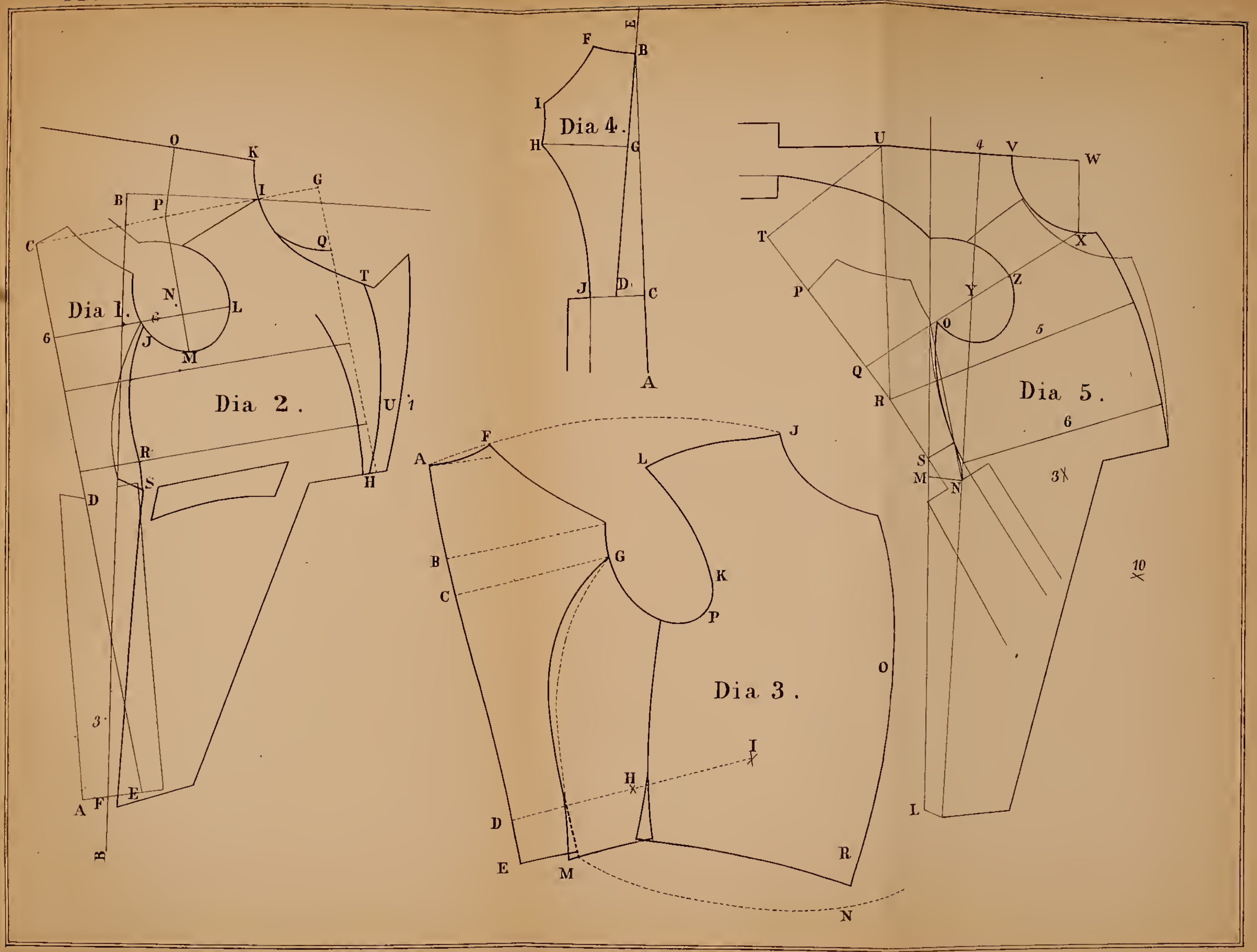



quantity to be taken out at the hollow of the waist between the back and the forepart side seams, say $1 \frac{1}{2}$ inch; mark $1 \frac{1}{2}$ inch from the back side seam to $R$, you may then move the back from the square, and place the back seam on the line $\mathrm{OK}$, so that the top of the shoulder seam touches the point I when the back lays in that position; mark the shoulder seam of the forepart by it; the upper part of the scye may be formed by a part of a circle, by finding a centre between the top of back scye and $\mathrm{L}$ at the front of forepart scye by 5 inches; the side seam may be formed by finding a centre between the points $R$ and $J$ by two-thirds of the breast measure; from that centre, cast the line from $J$ to $R$, which forms the upper part, the lower may be formed by a reverse curved line from $R$ to $S$; then take the width of breast 18 inches, and belly $16 \frac{1}{2}$ inches, by placing the back in the closing position as it will lay when joined; if you require a full chest to the coat, mark as much beyond the breast measure as fancy may direct, say $1 \frac{1}{2}$ inch, take the belly measure the exact size; the gorge formed by a quarter of a circle from I to $\mathrm{Q}$ is only suitable to a coat that is intended to button close round the neck, therefore, mark the gorge down according to your taste (say, 6 inches), mark from $\mathrm{G}$ to $\mathrm{T} 6$ inches, and find a centre between $\mathrm{I}$ and $\mathrm{T}$ by half the breast measure, 9 inches, and cast the gorge as from $\mathrm{I}$ to $\mathrm{T}$; the round of the chest may be formed by a circular line from a centre found between $\mathrm{T}$ and $\mathrm{U}$, the distance of three-fourths of breast measure, terminating the round at $U$ opposite the hollow of the waist; the bottom part may be formed by either a straight or curved line from $\mathrm{U}$ to $\mathrm{H}$; next take the length of lapel from $K$ to $H 21$ inches, and mark the bottom of the lapel square with the line $\mathrm{H}$, and likewise mark the top of the flap square with that line, and draw the plait line $1 \frac{1}{2}$ inch beyond the point $\mathbf{E}$; that gives as much spring beyond the back seam line as is taken out of the hollow of the waist between the side seams; the bottom of the skirt should be marked square with the back seam line to prevent the front from hanging too low; the skirt may be made any width you please; the line the buttons are to stand on may be formed as the line $\mathrm{T} \mathrm{U}$, by finding a different centre, and the front should be shaped according to it; mark the top of the lapel to your own taste, and the formation of the forepart is completed."

It is interesting to observe that Mr. Wyatt's system, as laid down by him, is not a purely breast measure one, for the element of lieight is introduced by using a proportion to fix the top of the side seam of the back, viz., 6 inches from the top, C. It seems evident that the author had found that the breast measure pure and simple is an unsafe guide for determining the depths. In his instructions for cutting a coat for a corpu- 
lent man, this is made quite clear, for he says, "I have selected for a model of delineation a figure of a large size in proportion to the height, the size of breast 24 in., and belly $26 \mathrm{in}$.: the height, $5 \mathrm{ft} .6 \mathrm{in}$. I regulate the bottom of back scye by the height and not by the size, as is very general with many teachers. The line the back scye rests upon is 6 inches from the top of the back seam, the same as the proportionate man of that height; the back scye and back neck are 3 inches, i.e., oneeighth of breast measure, and the width across 8 inches, that is, one-third of breast measure." Here we have the principle in embryo of height governing depth, and width regulating width, which has been carried out more fully and logically in Dr. Wampen's, the West-End System, and others.

It is worthy of remark that at this period (1822) coats do not appear to have been cut across the waist according to this author, for neither of his illustrations give us an example of it; we may feel assured that he would have shown it, and the more so if it had been a novelty. Mr. Wyatt had the reputation of being a good cutter, and was a man much respected by those who knew him.

\section{KILLEY'S SYSTEM.}

Mr. John Killey, of Liverpool, published in 1821 a small pamphlet of 18 pages, entitled "A New System of Cutting, made familiar to any capacity, in which is introduced a number of things never before made public," \&c., \&c. The very lengthy titles to these pamphlets seem peculiar to them. Unfortunately, the contents rarely correspond with the title page; for when this pamphlet is examined, it is found to be simply a pretentious improvement on Mr. Minister's system, with some few instructions added for stature measurement, or, as we should now call it, self-measurement, and the application of the measures for customers living abroad. The publication of such a small pamphlet, containing such a minimum amount of information, at the high price of eight shillings and sixpence, is a proof in itself of the poverty of knowledge of the period. A comparison of this and similar books with the works of the present day is quite a revelation, whether we regard the quality or the quantity given, as well as the price charged.

\section{BENJAMIN READ'S SYSTEM.}

Among the curiosities of tailoric literature should be classed "The Proportionate and Universal Table, being a Compendium of Arithmetical Calculation for finding the principal and only leading points in the Art of Cutting to fit the Human Shape," \&c., \&c., by Benjamin Read. This small work had reached a 
fifth edition in 1822 , so we must conclude that it had had an extensive circulation. The author states in his preface that he "conceives that a preface is scarcely necessary with the fifth edition of the Art of Cutting." But how any sane person could by any stretch of his imagination conceive or profess this to give any insight into the Art of Cutting will puzzle any reader.

The contents consist simply of a proportionate table or tables, in which all sizes from 20 inches to 60 inches, whether of breast or waistband, are subdivided into ten varied parts placed in columns. These quantities are to be used to form garments from a specified straight line, but no illustrations are given, so that it would be an absolute impossibility for any student to learn to draft any one garment by the directions given; and yet it attained to a fifth edition, and the author found it necessary to make an affidavit before the Lord Mayor that he was the sole inventor, perfector, and first teacher of this mode of cutting.

This arithmetical calculation of Mr. B. Read's first appeared in 1815. It can scarcely be called a System of Cutting, or else it would have merited being noticed before.

In 1848 "A New Scientific System of Cutting," by Read $\&$ Co., appeared, and it is stated by approbation of Her Majesty Queen Victoria and H.R.H. Prince Albert. Its form is a large folio, showing, when opened out, diagrams and explanations of the system. It comprises five parts or, rather more accurately, five plates with letterpress description. The Coat system is simply a graduated one, worked by graduated measures, which, it may be presumed, is the new scientific part. The 1st part gives the Coat system; 2nd, Chesterfields ; 3rd, Box Coats ; 4th, Breeches, Trousers, and Vests; and the 5th, Ladies' Habits. All these are drafted by graduated measures. The Trousers system is simple; it produces an open cut, with a straight seat and a rather large fork; a style of cut which was generally favoured at that time. Instructions are also given for cutting gaiter bottom Trousers with sewed-on straps.

\section{J. S. PEELE'S SYSTEM.}

At Whitchurch, Hants, in the year 1823, a small volume was issued by Mr. J. S. Peele, entitled, "Peele's Treatise on the Art of Cutting in all its various branches on a Quadrangular system by Geometrical proportions." This is a small work of thirty-six pages, and one sheet containing nine diagrams. The title is high-sounding enough, but the system is simply drafted in a square, the quadrangular system I presume; and the geometrical proportions are simply divisions of the breast 
measure. A not inconsiderable part of the letterpress is devoted to depreciating the merits of the author's contemporaries, presumably by so doing intending to extol his own merits by comparison. The profession was not much enlightened by this work, and it would not have had much cause to regret had it never been written, for the information is so meagre that one is puzzled at this period to inagine the sufficient cause for its publication.

\section{BYFIELD'S SYSTEM.}

A very curious old work was published in 1825 , by Robert Byfield, entitled "the Sectum, being the universal directory in the Art of Cutting, containing unerring principles upon which every garment may be made to fit the human shape with ease and elegance. Illustrated by copper-plate engravings and numerous tables of calculations."

In the Preface the author says : "The Work is so arranged that it describes every kind of garment, divided into sizes, each bearing an equal proportion, with a plan for laying down each size in the most accurate manner, together with the proper width and quantity required for each (including every different article which can be imagined of use in clothing), with descriptive and explanatory tables of sizes and plans annexed, and I find I have succeeded in rendering the useful Art of Economical Cutting perfectly infallible." The italics are mine. The profession to give a plan for laying down every imaginable garment is not so illusory as will be imagined, for directions are given to produce some garments that would astonish and puzzle most tailors; for instance, we have, amongst others, Men's Duffell Coats, Men's Flushing Coats, Boys' Millwright Frocks, Ladies' Corsets and Shifts, Men's Camblet Boat Cloaks, Capôts, Negroes' Jackets and Trousers, Negro Women's Petticoats and Negro Girls' Bedgowns, \&c.

The "unerring principles" are simply lay-downs for cutting out the curious assortment of garments mentioned, with very few and indefinite rules for producing them.

As a fair example, or rather a full example, I would direct attention to a Diagram of a single-breasted Frock (Dia. 4, Plate 6), which is given in the Frontispiece, the full directions for cutting which are as follows:- "Frontispiece, a Man's single-breasted Frock Coat with the measuring lines. From 1 to 2 is the length of the waist, from 2 to 3 the full length of the coat, from 4 to 5 half the width of the back between the shoulders, from 5 to 6 the elbow, from 6 to 7 the full length of sleeve, from 5 to 8 from point to point; 9 , the small of the sleeve; 10 , half round the breast; 11 , half round the waist. 
The pivot is a third and the sixth of a third of the breast measure; the proof line two-thirds of the breast, from the back seam to the front of scye; the two balance lines the same length."

The only rule or principle used is that of the old thirds, and that only in two instances; the one for finding the pivot from which to balance the shoulder, and the other to find the front of scye. These very simple and inefficient rules must have been of very little aid or use to a cutter, but they may be considered useful in the sense of being better than no rules at all.

\section{HADFIELD'S SYSTEM.}

When reading some of the old masters, one is sometimes surprised to see the sound sense and keen intelligence which seem to have guided their proceedings; more especially is this so when one reflects upon the small basis on which they had to found their knowledge. This remark especially applies when reading the "Tailor's Preceptor," by H. Hadfield, published in 1826 , for the author seems to have been a man in advance of his time. For instance, read the following instructions to find the height of back: "suppose a line to be drawn from the bottom of one back scye to the other, which will cross the back seam, then place the end of the measure even with the top of the back seam, pass it along this line and mark it on the measure. It is better in this case to be governed by a proportion of the person's height measure, than by a proportion of the breast measure. The width should govern the width, and the height the same." The italics are mine. The principle which the author propounds is, without doubt, a sound one, and shows the writer to have been a man who reflected deeply, and formed his conclusions after having well thought out the subject in its various bearings. The value of the enunciation of this principle will be better estimated if we remember the time when it was propounded, a time when the inch tape was only partly in use; and this is evident from the fact that instructions for measurement are given both by inch tape, notched brown paper, or parchment.

The work is entitled "The Tailor's Preceptor, or the Art of Cutting Garments to fit the Human Form with Ease and Elegance"; illustrated with twelve copper-plate engravings, containine upwards of thirty models of different garments. To which are added twenty-six tables, showing the necessary quantity of cloth required for each garment; and a receipt for making a compound to mark braiding designs on cloth, by H. Hadfield (of Manchester), London, 1826.

This system, like many others, is very imperfect; but it is 
distinctly an advance upon those who only used one quantity for subdivision to produce garments. This early glimmering of a fact is encouraging, showing as it does that thoughtful writers were not satisfied with the theory nor the practice that prevailed at that period.

\section{G. T. GOULDESBOROUGH'S SYSTEM.}

As illustrations have been given of the earlier methods of cutting, it will not be necessary, except in special cases, to give examples of the different systems; so a notice will suffice of the crude and imperfect system which was published in 1829, by G. T. Gouldesborough. It has as usual a long title, and is professedly on geometrical proportions: the cruder the system the greater the profession of geometrical principles in these early works. This work is entitled "A Treatise on the Art of Cutting in all its various branches on a Quadrant System by Geometrical Principles." It comprises a small pamphlet of twenty-four pages, and a sheet of ten diagrams. The following extracts from the preface and the concluding remarks will show sufficiently the quality of the work: "The rules laid down in the engraving are very simple and easy to be obtained; they are formed on principles of practical geometry, whereby the form of all garments is mathematically described. Those who possess this book, and wish to comprehend the system clearly, should duly examine the references in the models as they read, and mark the points as directed; they will then plainly see that there is a rule to draw every line by in the garment. The author assures the trade that he has made it his entire study for the last eight years, and has found that cutting coats across the waist puts every proportion out of its place that before had been taken correct; for whatsoever is taken out of the hollow of the waist must be taken off the top of the forepart, otherwise the coat will never sit close to the waist when unbuttoned. The coat in the plate possesses every good property that can be laid down. They are warranted to keep close to the waist when unbuttoned, the same as when buttoned, and to have a graceful appearance."

"Remarks on Practical Cutting.-I have now laid down a system for a proper proportionate figure, and when the figure is disproportionate, I leave the reader to his own judgment, as nothing can be more absurd than to attempt, as some teachers do, to lay down systematic rules for disproportionate forms."

The system itself is simply a breast measure one, and drafted in a square. The rules are very few and imperfect, and it cannot be considered from any point of view an improvement on its predecessors. 


\section{JOHN JACKSON'S SYSTEM.}

"The Tailor's Director or Anatomical Critic," by John Jackson, was published in London in 1830. It is illustrated with engravings of two full-length figures, and contains criticisms of Read's, Minister's, Wyatt's, and Killey's systems, and every other publicly known system. The egotism of this author is evident on every page; in the preface we meet with the following remarks, which exemplify the character of the writer: "Having accomplished what others have in vain sought to do, viz., a complete knowledge of all the causes and effects produced upon garments and clearly elucidated them to every capacity"; he drops the pen with good wishes to those who have not been so industrious in the field of discovery. Again, "It will clearly demonstrate the errors of all the preceding authors," \&c. In his description of the anatomical lines, as he terms some measures which he takes on the body, I observe one remarkable measure, viz., "from the top of the back seam through the crutch, and up to the neck in front is the position line." Mr. Read's proportionate system he pronounces to be absurd. $\mathrm{Mr}$. Hearn's to be impracticable, although he gives Mr. Hearn credit for his endeavours. He also gives some credit to Mr. Wyatt for his friendly instruction, "because his was the first attempt towards dividing the lengths from the widths." The author criticises very severely both the coat and habit systems of Mr. Minister. The works of Messrs. Killey, T. Good, Peele, and Golding, all share his disapprobation. There is only one point in which I can coincide with him, it is in his insistence that widths must be distinguished from heights.

The coat system which he teaches in his Improved Tailors' Era, is a purely admeasurement system, and I conclude, after some slight examination, a very uncertain and faulty one, when compared with the direct measurement systems of the present day.

\section{LOUIS STUMBKE'S SYSTEM.}

Another small pamphlet, of great pretension but of little merit, was published by a Mr. Louis Stumbke, in 1830. Its lengthy title is, "A Short and Easy Mathematical Mode of Cutting for the Human Figure," \&c., \&c., accompanied with a beautiful engraving of fourteen mathematical figures and several well-executed portraits, by Louis Stumbke, many years practical cutter in England as well as in Germany, who warrants this work superior to any other offered to the trade in Europe. This superior work is a simple pamphlet of 16 pages and 14 diagrams. The first four pages comprise the title page and introduction, containing some unmeaning absurdities which the 
author calls jokes; and of the 14 diagrams 7 are replicas. The Coat and Vest Systems are drafted in the square by proportions of the breast measure. With respect to trousers, the author says :- " Trousers are not in the engraving, as I consider that system is but of very little use to cut that part of dress. I can only say, from long experience in the Army Department, that the straighter they are cut in the front the better." Our knowledge is certainly not advanced in any respect by anything this author has written.

\section{INTRODUCTION OF THE TAPE INCH MEASURE AND SQUARE.}

Mr. Wyatt, in his work of 1820 , gives the credit of the introduction of the inch measure and square to Mr. B. Read; but Mr. George Atkinson, of 23 Castle Street, Falcon Square, claims the credit of having first introduced them. In a circular he says, "I am well known to the trade, and can say without fear of contradiction that I was the first person who used the inch measure and square, and reduced the trade of a tailor to a system, and this arose from an accidental circumstance. Mr. Butterfield, who lodged with me in 1799, had a pair of boots made by a Mr. Tucker, of Tiverton; on the bill of parcel sent there was the figure of a boot and instructions for gentlemen to measure themselves with a tape, and apply it to a scale of inches. I thought gentlemen might be measured for clothes on a similar principle. I made an inch measure of parchment, marked it with inches, halves, and quarters; I applied it and found it practicable. I considered a foot square would be useful in marking the cloth. I had one made: marked it with inches, halves, and quarters; this led to a square of two feet by one, which is the square in use at this time. From the use of the inch measure, the square, and great application, I reduced the trade of a tailor to a system. When I first began to use the inch measure, I was laughed at and ridiculed by the trade in general, as being of no utility. I had confidence in its use, as I found it more convenient to have the measures of gentlemen entered alphabetically in a book, than having a parcel of slips of parchment or paper hanging on a peg or line, liable to be torn or lost, and subject to increase or decrease according to the variation of the weather. A further use I found of the inch measure; that, by constantly using it, I could judge the size of a gentleman by my eye, which, by the old mode of measuring, never could be done. It is now 40 years since I commenced it, and $I$ have the gratification to see and know that it is not only used in this country, but in every known part of the globe where we have communication. I am as proud or vain of the 
name of a tailor as any gentleman or nobleman may be of the gift of a ribbon or garter from his monarch.

' Merit or disgrace from all conditions rise,

Act well your part, and there the honour lies.'

"My trade is the most ancient on record, and from the highest pinnacle of honour."

This has the ring of the sentiments of a good tailor. One can almost see his cheerful, smiling, ruddy face, and hear his clear voice as he uttered the above sentences, and feel that we should like to shake hands with him, feeling assured beforehand that we should have a hearty greeting.

This is the first printed claim met with for this decided honour, and if words can convey correct impressions, the tone indicates truthfulness and sincerity, and I should have little or no reluctance, especially in the absence of any other evidence, in awarding the merit claimed by Mr. George Atkinson.

\section{THE OLD THIRDS.}

In the course of my investigations, one thing has surprised me more than any other, and that is the total absence of any work containing the system so universally known as the Old Thirds. This is the more astonishing, because both French and German trade historians admit that to England belongs the credit of originating the "old thirds." For instance, Mons. Canneva, in his "History of Costume" (Paris, 1838), says: "The English have for a long period used a measure divided according to the calculations of a yard. This use had caused them to remark the comparative relations which exist between the various parts of the body, and to compare all the other parts with one of them, the measure of the chest of a man taken under the arms. They found that the length of the waist is the same as the half of that size, the breast onethird, the back one-third, the scye one-third, the side of the body one-fourth, and the height of the back one-sixth; they fixed the hollow of the waist-seam at the hips at two inches and one-quarter. A large number of French tailors, whose merit we willingly recognise, made themselves masters of this English method. They made some improvements in it-sorne of great, some of little use-and now we actually claim the honour of the invention. We do not wish to destroy an illusion which is flattering to us, but the truth is, this system now belongs to the public, or rather it belongs to everybody." This seems to admit sufficiently the claim of England as the original birthplace of this universal system. But if there remains any doubt, a few moments' enquiry will prove it. Firstly, we know that the length of King Henry I.'s arm was taken as the basis of our 
measurement. This length was called a yard, it was subdivided into thirty-six parts, each part was assumed to be equal to the joint of a thumb or pouce, as the French still call an inch. Now the 18-inch half breast is a number that is most easily subdivided into thirds, \&c., whilst the 19 centimetres half breast measure, which is considered by the French as the proportionate size of chest, cannot be so readily divided into thirds and sixths, \&c. This alone would have deterred its general adoption by the almost uneducated tradesmen of the period. Failing a written proof I applied to, I presume, the oldest English tailor living, who is an esteemed author himself, and would have the best knowledge of the subject "of any one living;" I refer to Mr. Minister, senr., who, at the time of writing, is above 90 years old. He says : "It afforded me much pleasure to see the progress made in producing garments connected with the tailoring trade since I was put to the business in 1802 . There was no such thing as system of cutting in those days, the shape was produced by what was termed the rock of eye system. The eye being globular and a very slippery member, there was no certainty where it would rest; it might be too much to the east, west, north or south. This uncertainty induced me to try and find some unerring principle to produce the shape required. I am sorry I am unable to give you the information relative to the system of cutting by 'thirds.' In the year 1815, I saw Mr. McAra produce a pattern of a coat by his plan, which he termed 'thirds.' Whether it was invented by him I am unable to say. It was the first time I had seen the plan, and think it very probable that he was the inventor." This testimony I consider to be very important and almost conclusive. It is also borne out by Herr Klemm, the German author of the "History of the Art of Cutting," who names London as the place of its origin. He says, "Lastly, there came 'the German Michel,' who helped all out of the difficulty. It was a German master tailor in London, who, in the first twenty years of this century, invented the celebrated 'old thirds.' It was improved partly by the inventor, and partly by others, so that it was very popular for about twenty years, when it was supplanted by better grounded systems of cutting."

The first little work of Michel's was published by Neukirk, of Bale; it was called "A New and Infallible System of Cutting, arranged in the newest arithmetical system, and calculated on the size of the human body," and was illustrated with three tables of proportion. This little book bears no date, which was very common of the books then published; still, I think I can with certainty say it was not printed before the year 1818, because Neukirk, the bookseller who published Michel's work, only commenced business in that year. And here we have personal 
living testimony that Mr. McAra drafted a system by thirds in 1815 , and the expressed opinion that he was probably the inventor. I am forced to the conclusion that whoever was the inventor of the method, it was not published in England, but was handed down from teacher to pupil, and so was spread throughout Europe, and probably the civilized world. The German who obtained it from England was sharp enough to publish it in Germany, and it became the basis of numerous systems being, or professing to be, improvements of it. I remember learning the system from a Mr. John Little, a teacher and professor of cutting, in West Street, Regent Street, about the year 1846. Mr. Little was successor to Mr. Thomas Bryceson, who also taught and cut by this system; but neither of these professors published any work that I have heard of.

In various systems we have the shoulder neck point obtained by a sweep from one-third in at the natural waist, and the front of scye is generally placed at two-thirds in from the centre of back, but the complete method seems to have been brought down by tradition only.

I have the pleasure to submit, for the inspection and information of my readers, one of the simplest and best methods of cutting by the Old Thirds that I know of. It was to my knowledge used successfully in conjunction with cross measures by my late worthy partner, who was well known as a good old tailor and a successful cutter. As he used it for many years, I feel certain that it is undoubtedly an old version. It is drafted for a proportionate figure 18 breast and 15 waist.

The Back, Dia. 3, Plate 7.-Draw the line A: E, make A to B

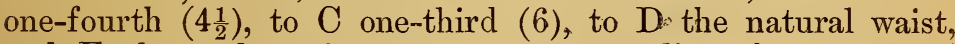
and $\mathrm{E}$ the style waist measure; square lines from each of these points; make $\mathrm{A}$ to $\mathrm{F}$ one-sixth (3), raising it $\frac{3}{4} \mathrm{in}$. above line. $\mathrm{C}$ to $\mathrm{G}$ one-third and one inch (7), B to G* ditto; draw top back, shoulder, back scye, and side seams, as diagram or to taste.

The Forepart, Dia. 3, Plate 7.-Place the back as diagram, square with the back seam, continue the natural waist line $\mathrm{D}$ to $\mathrm{H}$ and I. Make $\mathrm{H}$ one-third (6), and I two-thirds (12), from $\mathrm{D}$. Make $\mathrm{H}$ a centre, and sweep from the point $\mathrm{A}$; on this curve measure from $\mathbf{A}$ to $J$ one inch less than breast measure (17). Make I a pivot, and sweep from the point $J$ to $\mathrm{L}$ the shoulder, same length as back. Make from $\mathrm{C}$ to $\mathrm{K}$ two-thirds (12), and from $\mathrm{F}$ to $\mathrm{P}$ one inch more than twothirds (13), and form the scye through those points.

"Form the side seam by adding $\frac{3}{4}$ inch on round and slightly springing out below natural waist. Make the breast line $2 \frac{1}{2}$ more than chest measure $\left(20 \frac{1}{2}\right)$, from back and from natural waist to $R 1 \frac{1}{2}$ more than waist measure $\left(16 \frac{1}{2}\right)$. Make $J$ a 
centre, and from bottom of side seam at $\mathrm{M}$ strike a curve to $\mathrm{N}$. From one inch above $\mathrm{N}$ draw the waist line, add a little spring at bottom of side body, draw neck and front chest line through $\mathrm{O}$ and $\mathrm{R}$, and complete the diagram."

\section{W. LINDSEY'S SYSTEM.}

In a small pamphlet of eight pages W. Lindsey, of Cork Street, Bond Street, professes to give instructions how to cut Ladies' Habits and Pelisses, Regimentals, fashionable and unfashionable Dress, Frock, and Great Coats, also Boys' Jackets of every description, the result of 15 years' experience in London. The references are by letters. He propounds and illustrates the fact that all men who have six inches difference between breast and waist are not therefore proportionate, for some have extra long necks and round shoulders; short necks and ditto; or short necks, very upright and long necked position, or else medium upright. These figures may be all proportionate, but no proportionate coat will fit any other class than the one it is intended for; then it is evident that all the deviations are in the shoulders, and can only be remedied by a strict adhesion to nature. In conclusion, he says, "As every change of fashion requires a change of rule, which cannot be obtained from the printed figures, I engage to supply with the utmost exactness all the fashions, with the rules adapted, at a small expense yearly." There are no diagrams to illustrate his method, so no opinion can be given respecting its merit.

\section{A PROFESSOR OF CUTTING'S SYSTEM.}

A small and cheap work on "The Art of Cutting on Scientific Principles," \&c., was published in 1833 by a Professor of Cutting. The system is framed on the breast measure principle, and drafted on the square. It calls for no special remark, as it possesses no particular qualities. Like the major part of these small works, it almost-if not entirely-ignores disproportionate figures, and gives only a proportionate system to the poor tailor, with which he is supposed to fit all kinds of figures.

\section{THOMAS DAVEY'S SYSTEM.}

In the "Companion to the Cutting Room," by Thomas Davey, published in 1835, we have a work of greater calibre and value than many of more pretensions. The author is evidently a good practical tailor, a cutter of good practice, and a man of sound observation. Unfortunately, the work in my possession is without Plates, so that it is impossible to form a sound judgment on the merits of the system. In addition to the ordinary measures, he takes the height of back from a line square with the back seam and the bottom of the scye, which 
governs his height of back ; the remaining points are produced by divisions of the breast measure.

\section{H. MAINWARING'S SYSTEM.}

Mr. H. Mainwaring published in London, in the year 1836, a small octavo of 19 pages, which he called "The Tailors' Guide." It contains two sheets of diagrams, and seven tables of quantities of material required, and some very short instructions for cutting garments, certainly too meagre for any tailor to acquire a sound or sufficient knowledge by. The tailors who were dependent on such works as these for instructions in cutting were to be pitied. Their labours must have been attended with much toil and anxiety, and the results could scarcely be creditable to the tailor or satisfactory to the customer. The Coat system is based on the breast measure. The length of shoulder is obtained by a sweep from a point at onethird of the breast in from the natural waist; there is no quantity given for the depth of scye, and the directions for drafting are so imperfect that it is scarcely possible to draft the diagrams by them.

\section{DONALDSON'S SYSTEM.}

One folio, containing diagrams and key to the system, is considered sufficient by Mr. Donaldson to explain his "New and Complete System of Cutting, adapted for the use of Tailors and Clothiers." He says, "This system is so arranged that it will be found on inspection to be suitable to every variation of the human form, and to combine simplicity and beauty of style superior to any method now extant." It is really a system worked by divisions of the breast measure, but with such scant instructions as to make it practically useless. Why any author having so little to teach should rush into print is inconceivable. Folly or vanity seems to be the only valid explanation. It bears no date, but from the fact of the coat being cut across at waist, it would appear to have been published between 1830 and 1840.

\section{JAMES JONES'S SYSTEM.}

Amongst the treasures of the British Museum I chanced to find a large folio-sized sheet of stiff paper. It contains on top three illustrations, on the bottom and sides diagrams, and in the centre the following: "The Anatomical Standard," by James Jones, containing a system of measuring the human frame by means of an instrument, whereby all the various shapes and positions of the body may be fitted with the greatest accuracy; patronised by many of the most experienced practical cutters in the metropolis. As no instrument accompanies 
it, nor any letterpress, it is impossible to express any opinion as to its merits.

\section{DR. WAMPEN'S SYSTEM.}

The works of Dr. Henry Wampen demand more than ordinary attention, because no other scientific man has devoted so many years of study to our art, and his works have acquired a reputation unequalled by any other author or authors in England. It was a singular circumstance which first induced Dr. Wampen to engage in the study of garment cutting, and which shall be related as nearly as possible in his own words: "I went as a student to Berlin, to complete my studies. I took great interest both in art and philosophy, and a question was then much discussed whether the Grecian ideal of beauty was simply ideal or founded upon scientific bases? In reading up this question I was induced to measure certain statues, and I came to the conclusion that the Grecian sculptors worked on scientific bases. I had made some rough drawings of parts of the body and their sections. These lay on my table. One day a tailor who worked for me, a Mr. Freitag, came to try my clothes on; he saw my sketches on the table, when he said, 'You are just the man we want; you must write something. for us tailors.' I thought what nonsense, how can I, a simple student, write anything interesting or instructive to tailors. I must here explain to you that in consequence of our endeavours to instruct our people, there was a general upheaval and a desire for progress in art, science, and trade. A prize was offered for the best essay on the subject, and this it was my tailor, Mr. Freitag, insisted that I should compete for. He brought me a variety of books on the subject, some very good, others indifferent, but I gleaned something from all. I sent in my composition, and to my surprise gained the prize. I was highly complimented by some, others thought very little of my essay. This was how I came to write upon and study the art of draping the human figure."

It is rather remarkable that whilst he has gained such a high reputation in England, we do not hear of him in Germany, although, according to Herr Klemm, his first work, entitled "The Mathematical Art of Cutting Garments according to the different formation of Men's Bodies," was published by Herold, in Hamburg, in 1834. He adds, "the work contained five lithographed plates, and was, according to the author, recommended by fifty master tailors of Hamburg, and must, therefore, have been of some real value, as the author was not a master tailor, but according to the title of the book, a teacher of mathematics, anthropometry, and drawing. It contained besides the mathematical method of cutting, which, in the most important parts, was founded upon the system of "thirds," also an 
insufficient calculation of the proportions of the length of men's bodies, but which was of an unimportant use for practical cutting. The work appears to have had but a small circulation, as the first edition was not sold out in the year 1842, when the whole stock of the book was lost through the great fire of Hamburg."

His first work published in this country is dated January, 1837. It bears an elaborate title page, which will give some slight insight to the learned Doctor's ideas and principles. It reads as follows: "Instructions in Mathematical Proportions and Constructions of Models for Gentlemen's Dresses, applicable to the various shapes of the human body and to every fashion, with 15 plates including 87 figures, by $\mathrm{H}$. Wampen, professor in mathematics ; translated from the German."

In a preface of ten pages the author describes his aims and desires. The following extract will show that the author has ever written to elevate our craft, and has also indicated the means to be adopted: "As now culture of the mind is the first element wherefrom arises all that civilizes and improves us, and by which means all men become equalized; farther, when tailoring shall have been raised to an equally scientific degree, with so many other professions; when they shall have established academies for the young men who devote themselves to their business, for the purpose of obtaining scientific instructions, as a great many other trades enjoy; when the masters have also, about every fortnight, a meeting at which they are instructed by a lecturer of their own station, where their profession would be compared with that of other countries, as well as all that is useful for every enlightened citizen to know in addition to that respecting their general business; when all this would meet with due attention, support, and execution, all members of the trade would certainly become more extensive thinkers."

Many tailors have remarked that Dr. Wampen's works were written too scientifically and too abstrusely for ordinarily educated tailors to study with advantage. One great error underlies this opinion, which is, that the works are intended for selfinstruction, whereas, as the Doctor stated to the writer, that his works are intended to serve as text books for his pupils, and not for general or self-instruction. If this opinion has some force with regard to the later editions of his works, and every self-student will accord with it, how much more would it apply to the work under consideration? for it must be admitted that the terms used are abstruse, and the system itself is much more complex than the later editions.

Dr. Wampen next issued his measures for constructing models (i.e., graduated measures), and a four page pamphlet.

In the year 1850 he published his "Anatomy," preparatory 
to "Anthropometry," and fourteen years later his "Anthropometry." What tailors will consider his great work, is entitled "Mathematic Instruction in Constructing Models for Draping the Human Figure," by Henry Wampen, Ph.D., Professor of Mathematics, second edition, published 1863.

The work on anatomy is intended to give a sufficient knowledge of external anatomy to prepare the student to undertake the study of anthropometry. His work, "The Science of Anthropometry or Man Measurement," is, according to the Doctor, his greatest claim to originality and highest merit. In it he applies the principles of geometry to the measurement of the human body, and demonstrates their results with scientific accuracy. The students of this science acquire a knowledge of the principles embodied in the author's systems. Most tailors will rather accept them as indisputable than devote the necessary time and labour to master them. Those who have the inclination to learn, the capacity to understand, and the industry to persevere, will be rewarded by an accumulation of knowledge that the few, the very few, alone possess.

Dr. Wampen's is one of the most complete and elaborate systems of cutting that has been published in England. It contains plans for constructing models for almost every garment demanded of tailors. Amongst these the coat system has been most lauded by cutters. The method provides almost unlimited scope for adaptation to the ever-changing vagaries of fashion, and permits the exercise of a cultivated taste, whilst restraining the practisers within the bounds of scientific accuracy.

The principles which Dr. Wampen teaches and bases his works upon may be crudely stated in a few words. He states that as every body in nature possesses the two proportions of height and breadth, they must be both taken with consideration in draping the human figure. Every human figure can be placed under one of these categories, i.e., 1, The height proportion will be Equal to the width; 2, Greater than the width; or 3 , Less than the width. He urges that as tailors have to clothe the human body some knowledge of its structure is requisite. By applying geometrical measurement to the various parts of the figure he was enabled to deduct positive principles, which in his "Mathematical Instructions," he has adapted to the practical requirements necessary for draping the human figure.

It is true that the same principles had been advocated in a minor degree previous to these works; but it remained for Dr. Wampen to propound, consolidate, and systematise them in a scientific manner. But we shall fail to arrive at a just conception of the value of these works unless we are aware that they form the basis of a number of systems more or less 
Plate

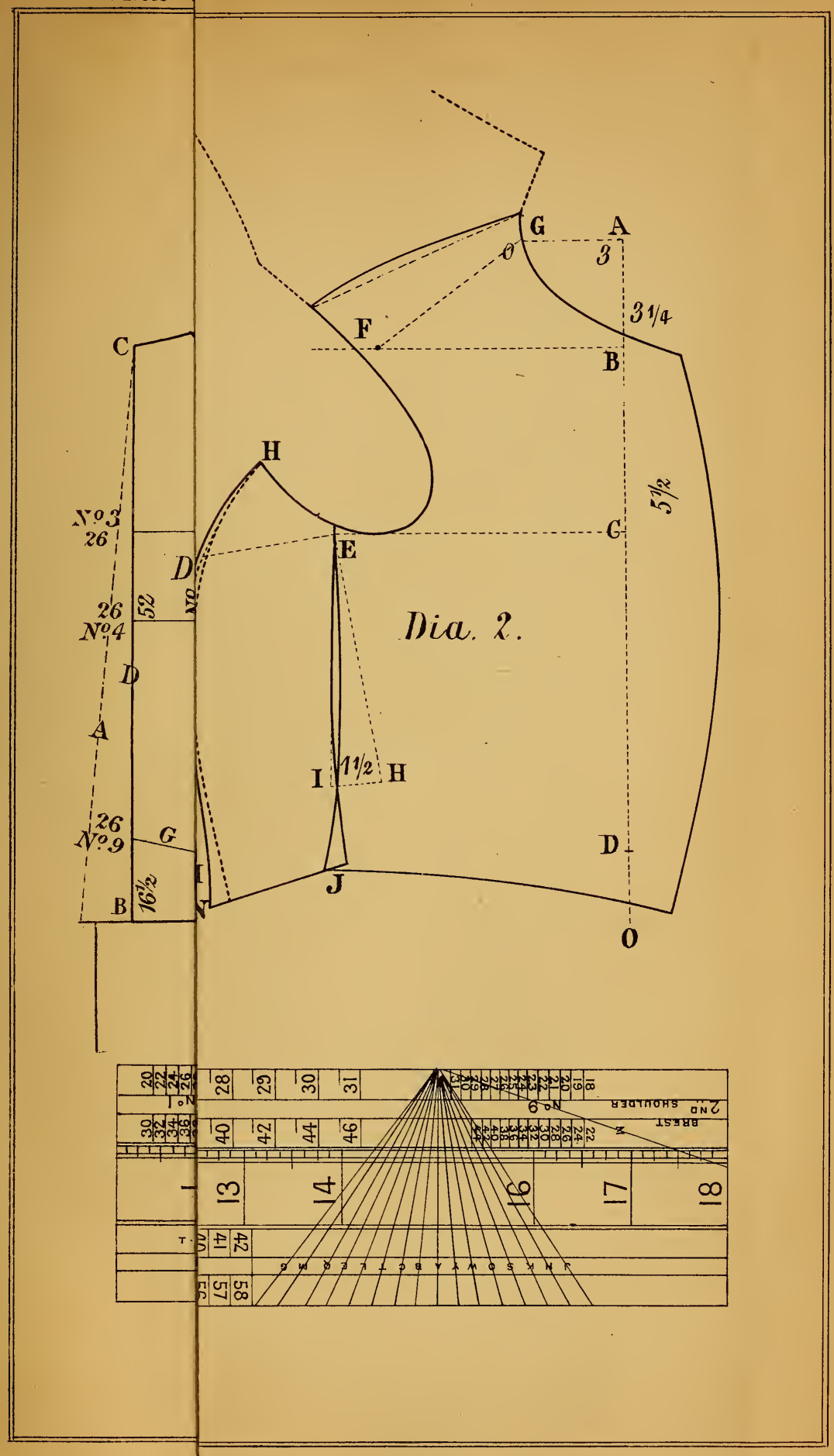




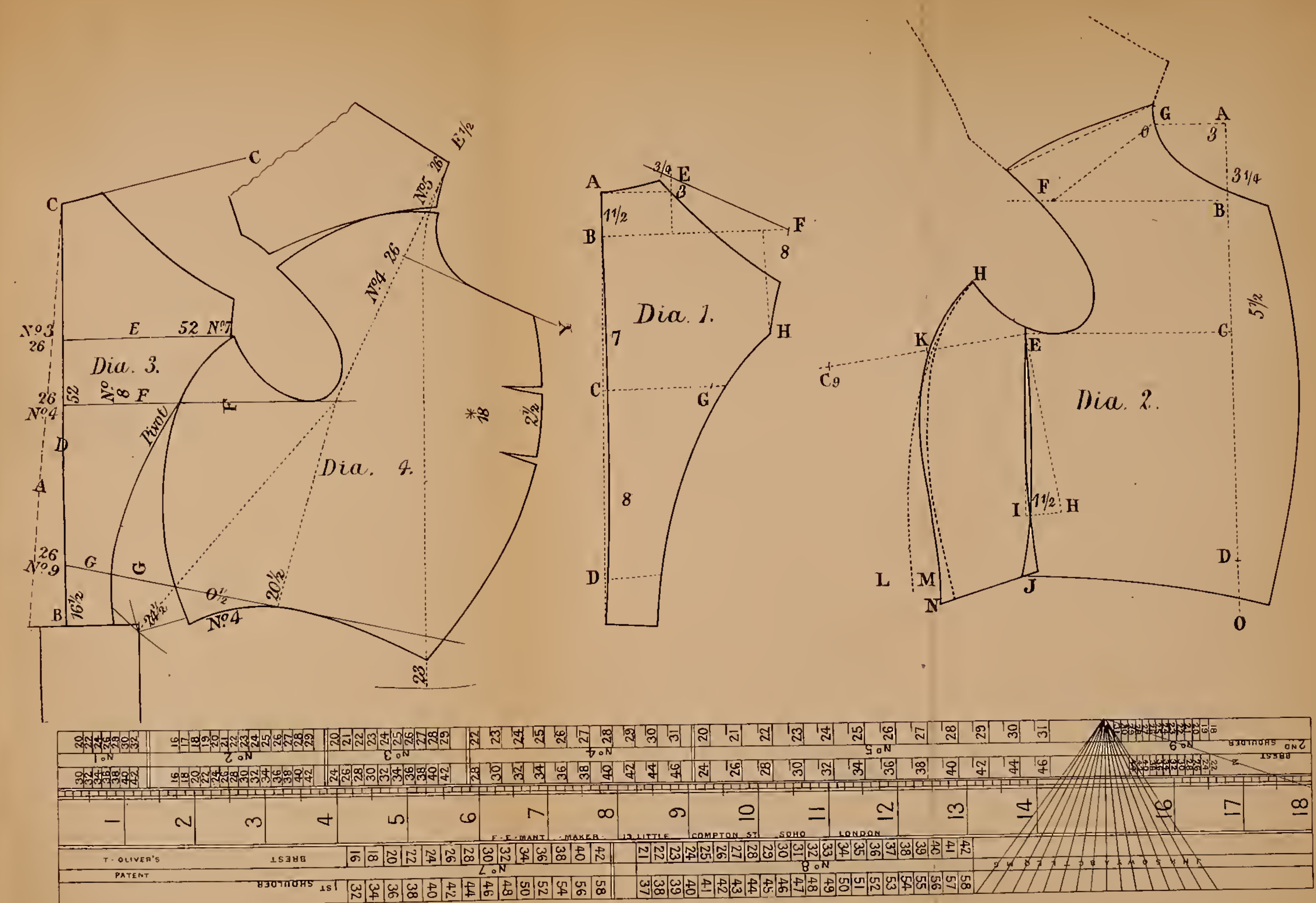

Dia. 5. 

valuable, each author professing to have made some greater or less improvement, or still worse, ignoring the source, wishing to be thought original instead of a mere copyist.

One feels that it is scarcely possible to do justice to the merits of these works without being suspected of undue adulation. The combination of labour, patience and scientific knowledge is unequalled in our profession. Various modifications and simplified renderings of his system have been and will continue to be published, possibly better adapted to the average intelligence of the ordinary tailor, but the principles which underlie them will remain, for they are based on scientific truth and the results of extended experience.

The following are Dr. Wampen's instructions for constructing a model for a proportionate figure 18 breast, 15 waist, and $5 \mathrm{ft} .4 \mathrm{in}$. high : "The models are constructed by placing their co-ordinates under right angles, and making them as large as the proportion numbers denote, which are given with them; for example, in the Back (Dia. 1, Plate 8), it is seen that A to $\mathrm{B}=1 \frac{1}{2} ; \mathrm{B}$ to $\mathrm{C}=7$; and $\mathrm{C}$ to $\mathrm{D}=8$. To continue, $\mathrm{A}$ to $\mathrm{E}=3 ; \mathrm{B} \mathrm{F} 8 *$ and $\mathrm{C} \mathrm{G}=4 \frac{1}{2}$.

"The Forepart (Dia. 2, Plate 8).-The co-ordinates A G, $\mathrm{A} \mathrm{B}, \mathrm{B} \mathrm{C}, \mathrm{B}$ F, are here again placed under right angles, and define through their proportion numbers. $\mathrm{A} B=3 \frac{1}{4}, \mathrm{~B} \mathrm{C}$ $=5 \frac{1}{2}$; but $\mathrm{C} \mathrm{D}$ is equal to $\mathrm{C} \mathrm{D}$ of the back. Farther, $\mathrm{A} \mathrm{G}=$ $3^{*} ; \mathrm{B} \mathrm{F}=7 \frac{3}{4} ; \mathrm{G} \mathrm{E}=9$, as is seen by a reference to the numbers. It must be particularly observed that $\mathrm{C} \mathbf{E ~} \mathbf{J}$ is equal to a right angle, and that $\mathrm{K} \mathrm{E} \mathrm{H}$ also must be taken equal to a right angle in the construction. The line $\mathrm{I} \mathrm{H}=1 \frac{1}{2}$ defines the position of the $\mathrm{E} H$."

"Placing the parts of the Models.-After we have constructed the hindpart of the model, and proceeded so far with the forepart as instructed, then we place the hindpart, Dia. 1, with its acromial point $\mathrm{F}$ in the acromial point $\mathrm{F}$ of the forepart, so that the levator line $\mathrm{E} \mathrm{F}$ of the hindpart falls in the levator line $\mathrm{F} \mathrm{G}$ of the forepart, and the levator vertex $\mathrm{O}$, is fixed. In this position of the hindpart to the forepart there needs only the shoulder line $\mathrm{F}$ of the forepart to be drawn, and a quarter of a unit added to the round of the shoulder; second, place the scapula point $G$ of the back part in the scapula point $K$ of the side part, so that the two scapula lines $\mathrm{C} G, \mathrm{~K} \mathrm{E}$, lie in a straight line, $\mathrm{E} \mathrm{K} \mathrm{C}$; afterwards draw the scye and side seam of back, $\mathrm{H} \mathrm{L}$, and make $\mathrm{L} \mathrm{M}=1 \frac{1}{2}$. Keep the hindpart fixed in the scapula point $G$ and move it round this fixed point $G$, with the point $L$ of the back part in the point $\mathrm{M}$ of the side part. Holding the parts of the model fixed in this position, draw first the side

* These two quantities are the later quantities given by Dr. Wampen. 
line as dotted line, and then draw the side seam as diagram, and the remainder according to diagram also."

It is evident from the above extracts, which $I$ have given as nearly as possible in Dr. Wampen's words, that his work never can become a popular trade instructor. The terms used are too abstruse, and unsuited to the greater number of our trade who have not had some instruction in mathematics. It is only just to Dr. Wampen to say that he never intended it for self-instruction or for general use, but as Dr. Wampen informed the writer, "I intended it to be a text book for my pupils." This will explain why it is not generally studied, and why it is not adapted for general use.

\section{EDWARD COGDON'S SYSTEM.}

An "Improved System of Cutting" was published by Edward Cogdon in 1837. It was issued in four parts, but unfortunately I have been able to see but three parts, the most important part-the Coats-being deficient. But I am led to conclude that it was purely a breast measure system, as in the introduction to the third part-on Breeches, Trousers, \&c., he says: "Many a careless man in measuring has made an excellent fit in a coat by only getting the breast measure correct, as all the other essential points will in a very great degree bear a regular proportion of thirds and fourths to that measure." The trousers system produces an open trousers with a straight seat.

According to this author a waistcoat is a most difficult garment to cut. This I venture to think is contrary to the experience of the present. He states: "At the present day waistcoats are more difficult to cut than coats, as there are so many different kinds worn." He continues, "The principal reason why waistcoats are more difficult to cut than coats is the impossibility of their being altered in making up (when made up), like a coat." The Vest System is a breast measure method, easily drafted, but with one great defect-a too short back.

The third part contains systems for drafting ladies' habits and children's dresses. These productions are very curious and not at all suitable to our present style of dress; still, they are interesting as specimens of the productions of the old masters, and the style and kind of garments worn at that period.

Messrs. Cogdon \& Co. also issued Plates of Gentlemen's Fashions every six months, according to an announcement on the cover of the System, but I have no means of judging of their character or quality.

\section{W. POWER'S SYSTEM.}

Another voluminous but yet complete work of its kind is "The Tailor's Scientific Instructor, or Foreman's Unerring 
Guide to Cutting," published by the author, W. Power. In the instructions, he says: "the author flatters himself that the system of measurement fully laid down in this work, and which is offered as the student's guide, although unique, and is consequently of the greatest value to the student as well as to his senior in this branch of the art. It will utterly refute the plan adopted by some formerly, that of taking all proportions from the size of the breast." "The measures which he alludes to comprise the upper, lower, and centre shoulders, the measure from nape of neck to natural waist, and the height of neck measure. It is so far interesting that these measures seem intended for use as supplementary ones, for he does not use them in the working of his system, which is a breast measure one with one height measure, viz., the distance from top of back to level with the back scye, which is obtained by one-twelfth of the height for a proportionate figure, and one-thirteenth for a corpulent one. This work is undoubtedly a credit to the author, for it must have required considerable knowledge of our craft and great perseverence to have compiled it. The work contains ninety pages of letterpress and numerous diagrams; besides which there is an appendix, showing lays for economical cutting, model order, cutting room, work delivery, log and pattern books, and in addition, two pages of useful receipts, a journeyman's $\log$, and a wages table.

\section{JOSEPH COUTTS' SYSTEM.}

A quaint old book is that published by Joseph Coutts somewhere between 1840 and 1850 or earlier. He called it "A Practical Guide to the Cutting Room," \&c. The style is peculiar to himself, for no other author I have met with has adopted the colloquial style of instruction. Besides, he commences by teaching how to cut garments for a child six years old, a very peculiar method, and then proceeds to youths, and afterwards, all kinds of men's garments, including liveries, uniforms, and clerical gowns, as well as ladies' riding habits. The work is illustrated by twenty-seven Plates, each containing two figures. Each Plate represents some event or action, as the playfellows, boys about to play, as well as the special dress. Each of these Plates is well drawn and has a special character, forming a unique collection of types of dress.

According to the author he, in conjunction with the late Mr. Duncan McAra, introduced the tape measure in 1809. He adds, it was first graduated by McIntyre of Glasgow; but no one who knew the author personally would place implicit reliance on his statements. It is very curious that not one of his contemporaries mentions his name, and this at a time when personal controversy raged amongst them. 
The system is founded on the breast measure principle, and is worked by subdivisions of it; some check measures are added to assist the cutter in his work. The diagrams are very well executed, the book is well printed and forms a handsome volume. Throughout its pages are scattered hints and instructions most valuable to the student, which prove that the author had a good knowledge of his subject, and was a thoroughly practical tailor. Altogether, the work reflects great credit on all concerned in its production.

\section{W. E. WALKER'S SYSTEM.}

Our old authors seem to have had a great fancy for highsounding titles to their works; as, for example, Mr. W. E. Walker, who published a work on cutting in 1839, and called it "The Tailor's Philosophy, or Complete Science of the Art of Cutting, in which the unerring principles of science are fully attained and laid down as a basis for the full development of the proportions of the human body," \&c., \&c. The book contains 100 pages. More than half of it is devoted to preface, introduction, and observations. The system is illustrated by three plates of diagrams, one of which is devoted to the coat system, another to the frock skirt, and the remaining one to the vest and trousers systems.

In the introduction, the author relates the following curious incident, which gives us an insight into the state of knowledge and practice of some of the cutters of that time. Says he: "An old man applied to me for employment, and to convince me of his superior talents, told me that he formerly filled the situation of foreman in a first-rate establishment in England. To try his abilities I invited him to display some of his geometrical knowledge upon the art of cutting, and indeed he was not deficient of confidence, for without the least hesitation he proceeded to comply with my request. Considering the old adage "that neither wise men nor fools can work without tools,'I laid before him the requisites for performing his operations, amongst which was the square; but this last mentioned article he scorned the use of, adding that he would show me how to cut without so troublesome an article. He commenced by first laying his left hand upon the cloth where he intended the neck to be, and marking from his, wrist round by the end of his fingers, he produced the neck to the shoulder point; he proceeded through the system, marking the shoulders, side seam, scye, \&c., by the dictation of his judgment, some application of the measure, and now and then spanning across the cloth for the different points in which he appeared astray: To conclude, this artist, when he had finished this extraordinary figure, assured me that it was excellent, a point which I did not 
dispute, but taking some more hints I bid him good morning, promising him at the same time that if I should require such a person, the next time he would be passing I would let him know."

There is one and only one noteworthy point in this work, and that is where the author asserts that the length of the forepart should be produced by the height, and the widths by the breadth measures of the figure. His rule for obtaining the proportionate height to the breast is original. He considers a proportionate figure should measure $36 \mathrm{in}$. and be $5 \mathrm{ft}$. $8 \mathrm{in}$. high. He says, " $5 \mathrm{ft}$. $8 \mathrm{in}$. is $68 \mathrm{in}$. ; if you double 36 it becomes 72 , $\frac{1}{18}$ part of 72 is $4 \mathrm{in}$., which deducted from 72 leaves 68 , and that is the proportionate height; consequently, if you take from any proportionate size, whether of man or boy, $\frac{1}{18}$ of double the breast measure, the remainder will be the proportionate height." In this one idea the whole value of the contents of the work is contained. The system is based on division, in which twelfths and twenty-fourths frequently occur, and a very crooked forepart with very little taste is the result. The whole rhodomontade about science is simple noise and bluster. One can only wonder that so small an amount of instruction should be thought worthy of publication, for no man by studying this work alone could hope to become a cutter.

\section{ADAMS'S SYSTEM.}

However Mr. Adams could have had the assurance to price his "Anatomical Self-varying System of Cutting" at thirty shillings, it is almost impossible to comprehend, as thirty pence is more than the real value. He had the bad taste and worse judgment to devote two-thirds of his letterpress to denouncing and imputing motives to members of the London trade. To any casual reader, personal rancour and disappointment are so self-evident that he approaches the system with great expectations if he be inexperienced, but with caution and even suspicion if he has read the same kind of querulous complaints over and over again, and found on examination they were the offsprings of diseased vanity. The self-varying consists in drafting out garments according to a scale arranged by the author. But a few glances at the ill arranged and worse drawn diagrams are sufficient to cause any reader to dismiss it to the regions of eternal forgetfulness.

\section{OLIVER'S SYSTEM.}

A system was introduced into London in the year 1840 by Mr. Thos. Oliver, of New York. It was announced with a great flourish of trumpets, and proclaimed to be of such great excellence, that it would supersede all methods that had been 
published. The London cutters were challenged and defied, and other equally questionable means used to make the system known and induce purchasers. The system is founded on shoulder measures, and is drafted by means of a ruler with divisions of those measures marked on it, and a protractor marked on the ruler is necessary to define certain angles. The use of this ruler and protractor makes it one of the most mechanical methods I have met with. The production of the system is by no means remarkably good, a short shoulder being its principal characteristic. The aid of a ruler and protractor being necessary to its use, must have been a serious drawback, as the loss or misplacement of these indispensable adjuncts is too serious an inconvenience for a cutter to contemplate. A second method is given by which the draft is produced by a combination of direct measures and divisions of the shoulder measures. This system, ushered in by so much boasting, lingers only in the memory as a past and gone failure. Still, as it is an exemplar of the early, if not earliest, shoulder measure systems, it will no doubt be of some degree of interest for those who desire to study various systems, and justifies my insertion of it here.

"Explanation of Ruler (Dia. 5, Plate 8).-The end at which the inches commence we will call the front, the other the lower end. The divisions marked Nos. 1, 2, 3, 4, 5, and 9 are divisions of the second shoulder measure. These divisions are used in getting the lengths, as from top of back to 26 on No. 3 , and 26 on No. 4, while Nos. 7 and 8 are used in getting the widths as from 26 on back to 52 on top of side seam, and 52 at front of scye. The second row of figures are proportionate divisions of the breast measure. Where you see a half-circle on plate, there place the centre of protractor and angle out by corresponding letter at the end of line.

"Measures for the Protractor System.-First, measure length of waist $16 \frac{1}{2}$, ditto 36 , elbow 21 , hand 34 . Place your measure at top of back and measure length of lapel 23; continue the same measure to haunch bone, or as low down as you want your waist seam $20 \frac{1}{2}$. Continue the same measure to centre of back at waist $24 \frac{1}{2}$, and to centre of back 23 , continue up to top of back 26. Place your measure at centre of back 3 or 4 inches down the back, bringing the measure over the shoulder, around the front and bottom of scye back to the same place, continuing the measure round either arm, bringing it back to the same place 52 , breast 36 , waist 30 .

"Back (Dia. 3, Plate 8).-First, draw line A on edge of cloth, measure down length of waist $16 \frac{1}{2}$, and full length; place your protractor at top of back and angle out by letter $\mathrm{C} \frac{1}{2}$. Place front end of ruler at top of back, the ruler extending along line 
D ; while there at 26 on No. 3, and without moving the ruler, mark at $26^{\circ}$ on No. 24 , or whatever the person's second shoulder measure may be; you now place lower end of ruler at bottom of back, and draw line B at waist, and mark at 26 on No. 9 ; at this point place the centre of protractor and mark at $0 \frac{1}{2}$. Draw line $G$; this line is used for getting the length of breast at front for a proportionate form. You next square out lines $\mathrm{F}$ and $\mathrm{E}$, place front end of ruler at centre of back, at 26 on No. 3, and mark at 52 on No. 7 (or whatever the person's first shoulder measure may be) for width of back. The remainder of back form to fashion or fancy.

" The Forepart (Dia. 4, Plate 8).-First, make side seam by the back; from the back draw lines $G$ and F, place 52 on No. 8 , on centre of back, and mark at front of ruler for front of scye. At this point place the centre of protractor and mark at letter $\mathrm{E} \frac{1}{2}$ on protractor; draw this line and place front end of ruler at star at front of scye, and mark at 26 on No. 4, and at the same time mark at 26 on No. 5 ; place your protractor at 26 on No. 4, and angle out for front of breast a neck gorge by letter $\mathrm{Y}$; from 26 on No. 5 angle the opposite way by letter $\mathrm{B} \frac{1}{2}$; take your back and place top of it at 5 , extending along $B \frac{1}{2}$, and mark shoulder seam, neck, gorge, and scye; you next place your finger on star at side seam, and draw in your back till it corresponds with the balance measure, or till the bottom of back seam touches the sweep of the balance measure, which is got by placing No. 1 on your inch tape at star at letter E, bringing it down front of scye ; then take your chalk in your left hand, and from front of scye sweep by your balance measure $24 \frac{1}{2}$, mark side seam by the back, sweep bottom of forepart by the distance from star at front of scye to No. 4; lay your back as if joined, and measure out thickness of waist; measure out to front of breast, one half of the breast measure and three inches, or as much as fashion may require, then form breast. If your back is cut wider than the usual distance, it is necessary to mark your pivot at the same place as usual, and when bringing in your back at waist, place your finger on pivot instead of edge of back; if you are drafting a coat for a crooked or straight form, apply one-half of your first measure from centre of back seam at 52, round bottom and front of scye to shoulder point, raising or lowering this point to the measure. You next apply your measure from the same place to the same distance down the other back, raising or lowering the shoulder point at scye. Provided you have shortened the shoulder strap by lowering it for a crooked person, you sink the scye somewhat deeper in front, and for a straight person reverse all these points, after you have ascertained the correct length of shoulder strap ; you next apply your balance measure, bringing it in at the waist, or letting it 
out according to the measure, instead of angling up by letter $\mathrm{E}$; for front of shoulder point, apply one-third of the first shoulder measure from top of back seam at letter $\mathrm{C}$ to star at letter $\mathrm{E}$, throwing it forward or bringing it back, according to the measure; this measure the more the person is forward will it throw the coat, and the straighter he is will it be the reverse. By strict attention to these rules, the most deformed person can be fitted."

\section{J. JOHNSTON'S SYSTEM.}

It is very difficult to determine the date of publication of nearly all works of cutting, from the fact that as a rule they are published without any. It is only by comparison that I am able to judge that it was about 1840 that Mr. J. Johnston published his "New and Easy Method of Cutting to fit the human frame with ease and elegance; illustrated with six plates, containing diagrams for all the principal garments now in use." The author, in his address, says: "I have discovered that one system cannot produce a fit for all sizes, therefore I have invented three, which will be found in practice to answer every expectation." These systems are founded on divisions of the breast measure. It is certainly remarkable that the author should think it necessary to arrange three different systems instead of adopting one to suit different figures. The second system produces a remarkable looking forepart, not at all coinciding with modern productions.

\section{G. WALKER'S SYSTEM.}

A work without any date of publication was issued by $\mathrm{Mr}$. G. Walker. It is called "The Tailor's Masterpiece," but why it was so called is not evident. On examination it proves to be the old work of Mr. Hearn's, entitled "Rudiments of Cutting Coats of all sizes." In the second edition it announces on the title-page, revised and corrected by G. Walker, successor to the late W. Hearn; but in the third edition Mr. Hearn's name disappears entirely, and "revised and enlarged by G. Walker" remains. Whatever merit attaches to Mr. Walker for the modernizing of the diagrams, and the additions and improvements he made in the diction (for there were improvements), should be readily awarded him. But posterity will denounce the barefaced appropriation of the results of another and a greater man's brain, and stigmatize as he deserves the man who trades on another's reputation. The original work has already been spoken of in terms of commendation, and the latest edition is equally commendable, for it preserves the same main features as the original, which is the English parent of direct measure- 
ment. The system of Mr. Hearn's was simplified and modernised. All vestiges of the "old thirds" had disappeared, and the depth of scye was obtained by measuring down the back seam to a spot level with the bottom of scye, which might be obtained by placing a square under the arm, or an inch tape around the body, and round was given for the blade-bone. Provision is made for cutting the coat across the waist. This seems to have been an unusual or novel proceeding, for the author thought it necessary to explain the cause and effect of cutting a coat across the waist. He says, "In the first place it may be said to be one of the best seams or methods adapted towards completing the set of the coat to the person, which no doubt adds much to the general effect of the noble figure of man." The measures and the manner of taking them were both curious. Firstly, the measures were taken over the coat, the breast measure being 36 and the waist 31 . These show a relatively smaller chest and larger waist measure than what we consider proportionate figures. It is surprising that so little is known at the present time of this system, which must have had a large sale and some renown in the middle of this century.

\section{JOHN JONES'S SYSTEM.}

I ought probably not to pass over without the briefest notice a work which was published in the Welsh language, by Mr. John Jones, of Liverpool, in 1841. It is entitled "Cynnorthwy I'r Ysingydd" (Tailor's Assistant). I may confess that my linguistic attainments do not extend beyond asking in Welsh for the commonest necessities; and I am entirely unable to translate it for the benefit of my readers ; and if I simply made an extract from it I am afraid they would not be considerably edified.

\section{THOMAS GOOD'S SYSTEM.}

In the year 1842, Mr. Thos. Good published the "True Principles of Scientific Cutting," \&c., but he had as early as the year 1826 published a system of cutting coats, according to his statement, in a critical review of Mr. Jackson's work, "The Improved Tailor's Ara." I have not seen the work, therefore cannot express any opinion of its merits. Mr. Good seems to have been a teacher in advance of many of his contemporaries, for he says in his introduction: "The governing length or height by size, must in the nature of things be erroneous. The height of the back cannot be regulated by the size of the figure, although it may correspond with it when applied to a proportionate man." This he proceeds to demonstrate by showing 
that the height of back for a proportionate figure might be $\frac{1}{4}=$ $4 \frac{1}{2}$ inches, whilst for a figure of the same height, but measuring $22 \mathrm{~B}, \frac{1}{4}$ would give $5 \frac{1}{2}$, in which would make the top of back 1 inch too high, and the waist 1 inch too short; and concludes, "from the remarks it will be seen that every part of a garment should be regulated by its relative part of the body." Unfortunately, Mr. Good adopts the common practice of depreciating the productions of his contemporaries, instead of leaving them to the judgment of posterity. But perhaps some allowance ought to be made for him when we find that it was the general practice of other authors. Probably, as teachers of the art of cutting, their interests clashed, and friction and illwill were the necessary consequences; and while we at this period condemn the proceeding, it should form an example to deter our modern authors from following such a pernicious practice.

\section{T. GOOD, JUN., AND G. BARNETT'S SYSTEM.}

In "Scientific Cutting simplified in a complete and comprehensive self-varying system," by Messrs. Thomas Good, jun., and G. Barnett, published in 1845, we have a comprehensive work containing systems for producing all necessary garments, combined with good sound advice on many debatable points, which show that the authors were good practical tailors. The system is based on a combination of the height and width measures. 'The height of back is formed by a proportion of the waist length, the other points by proportions of the breast measure. The work possesses also one great advantage, the same method is applied to all body garments, only varying in degree and application.

\section{A MASTER TAILOR'S SYSTEM.}

The "Tailor's Desire, or a Practical Method of Cutting a Coat, based on scientific principles, by a Master Tailor," is the title of an illustrated sheet published without date. It is a shoulder measure system, combined with balance measures. The balance measures are taken from a point made at one-third of the waist in from the natural waist. The principal measure is the upper shoulder measure, which is taken at four inches down the back from the collar seam; the tape is carried over the shoulder and back round to the starting point, 26 inches. This 26 inches is the scale by which the coat is cut, and from which the sub-divisions are made, as shoulder measure-26 in.

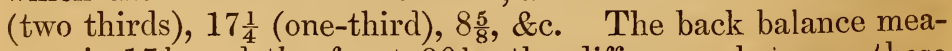
sure is $17 \frac{1}{4}$, and the front $20 \frac{1}{2}$; the difference between these two measures of one-eighth of the shoulder measure ( $\left.3 \frac{1}{4}\right)$ shows that the figure is proportionate. The degree of straightness is 
ruled very properly by the size of the shoulder. It is obtained by casting a curve from the top of the back, and the waist point as a centre; a mark is made on this curve at two-thirds (17 $\left.\frac{1}{4}\right)$ distant from back. A line is then drawn from the waist point through this point on the curve; beyond this point, and on the same line, a mark is made one-eighth $\left(3 \frac{1}{4}\right)$ distant. On this point the top of back is placed, which governs the position of the neck point. This system is worthy of notice as a combination of shoulder and balance measures, and has certainly some good points in connection with it. It produces, according to the diagrams, a very fair looking forepart; but in default of an upper shoulder measure, or some other height measure, it would, in my opinion, fail to produce a satisfactory result for either high or low-necked figures. The author gives his reasons for adopting a shoulder measure; he says, "In all my researches after knowledge in the Art of Cutting amongst the renowned artists of this great metropolis, I was obliged to conclude that the praise due to them was to be attributed more to their judgment and experience than to their science; and as they could not convey to me either of the qualifications, I was left after all short of what I was seeking for, and that caused me to think more for myself (and yet not neglecting any opportunity that I thought would afford information, and by this means I got the idea of a shoulder measure), and the result of my study I now publish for the benefit of those who now are, as I was, dissatisfied with what they have." So according to the author this contribution to our trade literature is an original production.

\section{ELLARD'S SYSTEM.}

In Mr. D. Ellard's "Gravitating Balance System," we have another example of the recognition of the principles, that height and width are both required to the proper formation of garments. The system is worked on a centre line, drawn at right angles with the back, the line at one-fourth down is prolonged to the full chest measure; at the distance of half the breast on this line, and through a point at waist, situate at onetwelfth less than the breast, the centre line is drawn. The height of back is worked according to the height, the other divisions of lengths and widths are proportions of the chest measure. There are directions for various kinds of figures, sizes and positions, as well as systems for producing trousers, vests, and habits. As Mr. Ellard was well known as a thorough practical tailor and an experienced cutter, his work is deserving of some attention and consideration. This work is published without date, but from internal evidence it may have been published about 1850 . 


\section{WHITELAW'S SYSTEM.}

Messrs. Whitelaw and Son, for many years teachers of cutting in John Street, Golden Square, published a System of Cutting, but, as usual, without date. Their coat system is founded on the breast measure, and is marked by divisions of that quantity. It has the usual weakness of breast measure systems when applied to corpulent men's coats. The authors treat these figures as if they were all of the same length of shoulder, whether they are $6 \mathrm{ft}$. 4 in. or $5 \mathrm{ft}$. $4 \mathrm{in}$. Respecting the back height they say, "These figures are also short-necked in proportion to the chest measure;" their method of ascertaining the height is to measure across the width of the back, and also from the top of neck seam to the bottom of back scye. But failing this angle measure, "Take half an inch off at top of back for a 20 inch B., gradually increasing it to one inch for a 24 B.; keep the back top the same width, reduce the back shoulder, and then take off the forepart the like quantities." The trousers system is so far peculiar that it is worked by a front line, at the distance of one inch more than the waist measure from the side line. The fork is formed by half an inch more than one-third of the tight thigh measure, and one inch extra on the underside at top of fork; the slope of seat is formed by a line drawn from point of fork through a point, the remainder of waist $\left(7 \frac{1}{2}\right)$ distant from side seam. For a corpulent figure, this would make an absurdly close draft, but the authors modify the rule by making a nominal waist measure, in proportion to the tight thigh measure, and which they consider to be five inches in excess of it. Any quantity the real waist measure is in excess of this measure, they treat as disproportion of waist. The coat system has had a very fair reputation, and the trousers system I have heard highly spoken of.

\section{W. ALEXANDER'S SYSTEM.}

It is somewhat surprising to see printed as the heading of "The Tailor's Directory," by W. Alexander, 1844, "Third Edition." The suspicion arises involuntarily that it must have commenced with the third edition, as the information it contains is so meagre. The only reasonable explanation is, that the curiosity of the trade was aroused by the announcement that the pamphlet is by W. Alexander, late Practical Cutter in Paris, "who warrants this to be his true and secret system." This affectation of secrecy must have been attractive, if it really reached to a Third Edition, as it was its principal if not only attraction. For a breast measure system which gives one-half the breast measure to produce the depth of the scye, without any qualification as regards height, is so far behind the ascer- 
tained facts of the period, as not to merit much attention or study. Some few ordinary instructions regarding making-up, are dignified on the title page, as "A Complete Practical Treatise on the Art of Making-up." Little if anything was added to our knowledge by the publication of this small pamphlet.

\section{W. CREES' SYSTEM.}

Some considerable advancement in scientific cutting was made by Mr. William Crees, in his "Practical Treatise on Cutting Garments," published in 1844. This work has not had the reputation its good qualities deserved, or I certainly should have heard it mentioned or seen it before I was told of its existence by a friend, to whom I am indebted for its perusal. A very modest introduction prefaces the instructions, in which the author states very forcible reasons for not using a proportion of the breast measure to determine the depth of the scye, and gives as examples of the futility of the breast measure, that of a youth $6 \mathrm{ft}$. high and 32 in. breast, and a short stout man $5 \mathrm{ft}$. high and 44 in. breast. The author proposes to meet these deficiencies by taking proportions of the height instead of the breast to obtain the required depth. The System produces a straight forepart with a large scye. The height of back is obtained by measuring across to the centre of the back pitch, and from there diagonally to the top of the back seam. An increased scye measure is used to obtain some widths, i.e., the scye measure plus 1 inch, as 17 scye and 1 inch $=18$ inches. The depth of scye is got by half the natural waist length and $\frac{5}{8}$ inch added. The straightness of shoulder is at 1 inch more than breast measure from the back seam. The application of these principles to corpulent men's coats is evident, as for a man measuring 24 breast, 17 inch natural waist, and 21 scye, a much smaller coat behind, a higher scye, and shorter back, would result than from a coat produced by a purely breast measure system, without the application of some arbitrary rule or the exercise of what is called judgment, but which for an inexperienced cutter simply means guess.

\section{T. PICKLES' SYSTEM.}

A work on cutting was issued by Mr. Thos. Pickles, not bearing any date of publication, but evidently a production of the middle of this century. The coat system is a breast measure one pure and simple, with all its inherent defects. The singular distinction is made between the frock and dress coat drafts, that the former is produced one inch longer in the back than the latter, and also one inch longer in the shoulder; 
because, says the author, "in my opinion, when a coat is required longer in the waist (this one is 19 waist), a deeper shoulder should be cut, not that any improvement can be made in the fit by so doing, but merely in appearance, for after all this is but a matter of taste." A remarkable opinion, indeed, for it indicates how shallow must have been the knowledge of the teacher, and grave doubts arise as to whether he could possibly have been a practical cutter. In the corpulent man's coat very little provision is made for the disparity between the height and the breadth; except that for a man measuring 23 breast and 24 waist, the coat must be cut as for a 22 breast and 24 waist, and the depth of back pitch must not be quite onethird of the adopted breast measure.

\section{“THE TAILOR."}

Messrs. Houlston and Wright published a small work entitled "The Tailor," in their Industrial Library. It is a work of 96 pages, in which the author enters rather fully into the subject, taking into consideration the choice of a trade, the apprentice's duty, the various stitches he has to learn; also some rules to cut a suit of clothes, as well as a brief historical sketch of the trade, and concludes with some excellent advice to apprentices and journeymen.

\section{J. WOODS' SYSTEM.}

In a small pamphlet of 16 pages, accompanied by two sheets of diagrams, Mr. John Woods published, in 1847, "A New and Complete Practical System for Cutting Trousers of every Description and Style, both French and English." The system is a centre line one. The centre line is found by one-fourth of the waist measure and three-quarters of an inch at top, and a fourth of the size of bottom at the bottom. The diagrams show various styles of bottoms, such as the French and gaiter bottoms, and those with sewed-on straps. Compared with the plain style of trousers now worn, these seem to be fearfully and wonderfully shaped. Mr. Woods' system is well worthy of study, and is remarkable as the first separate work on Trousers Cutting, as far as I have ascertained. It produces a moderately open trousers, with a medium sized fork, and an average degree of crookedness.

JAMES H. CHAPPELL'S SYSTEM.

In the year 1847, a system was published by James H. Chappell, which he named "The Ellipsis System, being a delineation of form and proportion by angles and right lines, and just application of two simple measures for the fitting 
principles." The said method is worked by the use and comparison of the Transfer instrument, which the author asserts to be "not a perfect and infallible guide, but superior in correctness and dispatch, and that it is capable of correcting the faults of the great majority of rules based on the division of the breast or waist measures, or measures of heights, lengths, or proofs." The author adds, "The Franklin Institute of Philadelphia, and the Master Tailor's' Society of Paris, have awarded it certificates of merit, and the Masters' and Foremen's Societies of Edinburgh have adopted it in practice." And yet I am bold enough to say that at the present time neither of those bodies are aware of its existence. A large sheet of diagrams, very nicely drafted, evidently the production of a skilled tailor, accompanies the duodecimo pamphlet and paper instrument which is used for drafting the method.

\section{W. E. WALKER'S CARD.}

Mr. W. E. Walker published what he entitled "The only true Tailor's Card," containing the various heights, with their correct proportionate chest measures, and aliquot parts of chest measures. The title seems to explain sufficiently its purpose and use.

\section{T. BARTLE'S SYSTEM.}

Following on the lines of Mr. T. Oliver, although differing in several respects, is the "New and original System on the Art of Cutting Coats, Habits, \&c., founded upon the shoulder, scye, and breast measures, calculated to fit every size and shape," \&c., by Thomas Bartle, without date, but published I believe in 1850. The author's aim will be evident in the following seutences: "It will be seen by reference that I ground iny system upon the shoulder, scye, and breast measures, and apply the different measures to find their own proper parts in a simple and efficient manner." He states that "you can take six men all measuring 36 breast, and all varying in their shoulders, yet the breast measure method would produce the same form for all. The first attempt to remedy this defect was made by $\mathrm{Mr}$. Oliver, but he used too many measures, a fault which the author avoids." The height of back is obtained by measuring across from top of back seam to bottom of back scye, $8 \frac{1}{2}$. The upper shoulder measure is also taken from nape, under arm, and back again to the nape, 26 . The scye is also measured $15 \frac{1}{2}$. It is worthy of notice that this system is grounded upon the upper shoulder and scye measures. The system is worked out by divisions of those measures, and produces a very satisfactory looking forepart. Only five plates of diagrams are given, and the instructions on variations are contained in five paragraphs. 
The author in conclusion says, "I feel convinced it is utterly impossible to command a good fit in any but the most strictly proportionate figures by a breast measure system, but that by properly combining shoulder, scye, and breast measures, a good fit must be produced without exception of any shape or size."

\section{LIVERPOOL CUTTING SOCIETY'S SYSTEMS.}

A work of a peculiar character was published in 1855 by the Liverpool Cutting Society. It was entitled "A Collection of Rules for Cutting, comprising forty different systems, selected and approved by the Liverpool Cutting Society, with diagrams to each rule." As there is neither introduction, preface, nor any explanation given for publishing these various systems, we are left to our own imagination to supply the omissions. The book contains 10 plates with diagrams on each, and some letterpress of quantities to draft the diagrams by. The 40 diagrams comprise two vests and two trousers systems, the remaining number are coats or parts of coats. The systems are more remarkable for their variety than any other quality; some of the productions cannot be otherwise justly described than extraordinary. The coat systems are all produced by divisions of the breast measure except one sheet, the diagrams of which are to be enlarged or diminished by a geometrical scale. In two cases only are supplementary measures used, and those are of the simplest; the first simply takes the measure down to opposite the centre of the back scye, and the other measure in addition the width of back, and from there to the centre of the back seam, some traces of the old thirds can be found in several of these systems, but the greater part display only constructive ingenuity without any guiding principle, while others are evident reproductions of patterns framed into systems.

It is difficult to conceive what useful purpose the publication of heterogeneous systems was intended to serve, or why they were published.

\section{HANGER'S SYSTEM.}

A "Shoulder Measure System," by Messrs. Hanger, was published as usual without date. Rather curiously, I am able to fix it very closely, as those gentlemen appropriated, without any acknowledgment, a portion of the first paper I contributed to the West-End Gazette in February, 1863. I ought possibly to feel flattered, but the suspicion does crop up, as I know they have unscrupulously appropriated some letterpress ; may they not have taken the same freedom with some other author's system? In the introduction we are told that "a good work on Cutting, one that has unerring principles for its foundation, and will not lead 
even the most unskilful astray, has long been wanting; such a work is the one before you." Again, "in every instance where the system has been applied, not one single misfit or alteration has been the result." "It is regrettable to find these claims for infallibility so persistently urged, as they excite expectations in the inexperienced which are certainly doomed to be unfulfilled. The authors use five measures above the usual ones to draft their system, viz., front of scye, height of back, lower shoulder, shoulder, and attitude measures. The last one is the difference between the lower shoulder and shoulder measure, and is as far as I know original. One error seems glaring, i.e., the shoulder scye point of the back is placed on the half breast line, so that the forepart would be made crookeder or straighter according to the width of the back, which is purely a style dimension. This system seems to have received some considerable favour, for it reached a third edition according to the copy before me. Still, it is one little heard of among quite modern cutters; but it affords further evidence of the progress of the shoulder measure being considered by many as the proper basis for division, although improved methods may have superseded this one.

\section{COMPAING AND DEVERE'S SYSTEM.}

A very important addition was made to our trade literature in 1856 by the publication in England of "The Tailor's Guide," by Messrs. Ch. Compaing and Louis Devere. This work was founded upon an original method by Mons. Compaing, sen., and published by him in Paris in 1820, with the title "L'Art du Tailleur." "The system is founded on certain direct measures taken on the client. The original one required 24 measures. These were reduced in 1852 and 1856 to 17 , in 1860 to 11, and in 1866 to 6 measures for ordinary structures. The latest work by Messrs. Compaing and Devere, entitled "The Complete Manual of Cutting," Part I., published in 1875, is a handsome folio edition, containing, besides numerous other illustrations, four excellent anatomical illustrations. The letterpress and general appearance of the work are a credit to the publishers and the trade. As I have indicated, progressive improvement, by simplifying the application of the method without departing from the fundamental principles of the original, has been the prevailing idea of the authors. Therefore, it is not surprising to read in the concluding paragraphs of this work the following excellent observations : "We will observe, that our ideas and aspirations are always on the side of progress and advancement, and we believe that further progress in our art will be in the further combination of anatomy and physiology, with true mathematical principles of cutting." Messrs. C. and D.'s system is both unique and original. Their centre point or fixed 
measuring station is not used in the same manner by any other author. Their works descend to the minutest details, which make them rank amongst the most complete and best representatives of measurement principles and methods that we possess in our literature.

\section{TROUSERS SYSTEM.}

Dia. 5, Plate 9.-The principai measures are : side, 41 inches; leg, $31 \frac{1}{2}$; waist, $15 \frac{3}{4}$; and seat $18 \frac{3}{4}$.

Front.-First, 0 to $31 \frac{1}{2}$, the length of leg seam. Second, 0 to 41 , side measure. Third, $31 \frac{1}{2}$ to $36 \frac{1}{4}$ is $4 \frac{3}{4}$ for the level of seat measure. Fourth, inside, from $31 \frac{1}{2}$ we mark $3 \frac{1}{8}$, or one-sixth of seat $\left(18 \frac{3}{4}\right)$ for the dress fork point of front. Fifth, from $36 \frac{1}{4}$ to $9 \frac{3}{8}$ is half the seat measure. Sixth, from 41 to $7 \frac{7}{8}$ is half the waist measure.

BACK.-The fork point is $5 \frac{1}{2}$ wide, and $\frac{3}{4}$ below the fork point of back. On the seat measure line there is allowed $1 \frac{1}{2}$ inches extra width for ease of movement. At the top there is extra width allowed beyond the half waist for the large fish over the seat.

\section{BEDFORD'S SYSTEM.}

A system of cutting by direct measurement was issued in 1870, by Mr. Bedford, entitled, "The British Reformed Practice of Cutting Gentlemen's Coats and Ladies' Riding Habits." This author labours under the same infatuation as many of his predecessors - of over praising his own production. He states that he wishes to exhibit "the art in all its simplicity," and that his "explanations are full and perfect, and will enable any tradesman to cut all kinds of coats accurately without fitting on." When the system is examined, I find to draft it requires fifteen extra measures to be taken, and four marks made on the coat for stations. The forepart is covered by such a mass of lines as to make it very complex. Besides, the impracticability of any system measuring from the points on the front, chest, and waist, has been again and again demonstrated, because if one measure is wrong the whole superstructure is erroneous.

It is very much to be regretted that authors and inventors do not make themselves acquainted with the works of their predecessors, for it would save them an immense waste of time. For instance, this gentleman claims the discovery of the front and back balance measures as original, whereas they were well known to the trade long before he wrote, and, personally, I used them twenty years before he published this work. These two measures were also applied in a Direct Measurement System by Mr. F. T. Prewett, which was published in the first number of the West-End Gazette, in July, 1862. 


\section{R. MORGAN'S SYSTEM.}

A pretentious work was published by R. Morgan, called "The Art of Cutting on an entire new plan, made thoroughly comprehensible without the aid of a master, on unerring principles, adapted to garments of every description, by R. Morgan." As usual, when so much is professed, there is really less information to be gained. The letterpress of the work is contained in 16 pages, nine of which contain the introductory remarks, and the remainder the instructions. These do not err on the side of prolixity ; for instance, "The Backs :" "These are given in full and require no particular remark." Then follow some few general remarks but no further instructions. Again, "The Coat Draft:" "The coat draft is so simple that any description of it would only tend to make it less so, so I may be excused from attempting it." The system, if such it may be properly called, is a method of copying certain varieties of sizes which Mr. Morgan has laid down in 17 full-sized plates. How any young man could become a cutter with or without a teacher with this method I am really unable to devise.

\section{B. TILLEY'S SYSTEM.}

After reading the very modest Introduction to Mr. B. Tilley's "Tailor's Tutor," one is certainly prepossessed in its favour. The form and price of the work leave little to be desired, except the impossibility of its being a complete work in such a small compass. That I am perfectly justified in this remark will be clear when I quote what the author says, under the heading of Overcoats, \&c.: "Knowing, as I do, that the mind of any man, even that of the merest tyro in the trade, if he have a head on his shoulders, and if he has gone through this work, will readily suggest to him how to cut all kinds of overcoats," \&c. This is a very easy way of teaching how to cut overcoats. The instructions on disproportion are almost, though not quite, as crude. The book has 42 pages, and contains systems for drafting dress coats, vests, habits, cloaks, trousers and gaiters, and alterations for erect and stooping figures. The coat system is founded on the breast measure, with an additional measure for the height of neck, and is of average merit. It is a sufficient index of our progress that no one in the present time would think such a meagre work would supply the intellectual demands of our trade.

\section{H. JOHNSON'S SYSTEM.}

Two pages of diagrams, and two pages of letterpress contain the improved systems published in 1862 by Mr. H. Johnson. 
The coat system is an adaptation of the Old Thirds; where the improvement comes in the author does not state, and we are left to conclude it is only in the title. The systems seem to merit no special remark, neither of praise nor condemnation. It is not possible that the author considered they comprised a complete method of cutting, and that they were intended as such. They appear to me to be intended to serve as a text-book for the author to use to give fuller and more detailed instructions in propria persona.

\section{THE WEST-END SYSTEM.}

A special and peculiar interest is attached to the publication of the "West-End System," because it is a method which is extensively practised throughout the world, and probably more than any other system, by English cutters. It is peculiar for various reasons. One is that it originally appeared in the West-End Gazette, the first part being published in the number for January, 1871, and it was continued until January, 1874. It was first published in book-form in July, 1875, revised and improved. In the preface to the third edition the authors announce that they have still further improved the System, but "without violating the principles of the work." The peculiarity of this System is that it is the joint production of five experienced practical tailors. To this remarkable fact; as well as to its intrinsic merit, may be attributed its extraordinary success. The principles upon which this System is founded may be properly described in the authors' own words, in the first article in 1871: "We have, after due consideration, decided to form our coat system upon a combination of the height and width measures"; and this they carry into effect by means of the natural waist, scye, and shoulder measures. Respecting the changes, the authors say that "should the trade at any future time require another addition, and should we feel convinced that any improvement might be possible, we should be equally ready and willing to place it at the service of our students, being fully convinced that it is only by constantly endeavouring to improve that we shall attain perfection."

The System is simple and easily drafted, being produced mostly by square lines, and so easily acquired. It possesses one great advantage, that the same method is used to produce all kinds of coats for gentlemen, as well as jackets, habits, \&c., for ladies. In the three volumes containing the complete System, articles on trying-on, alterations, \&c., are added, making a very comprehensive work. In March, 1887, this System had reached the Sixth Edition. 


\section{Plate 9.}

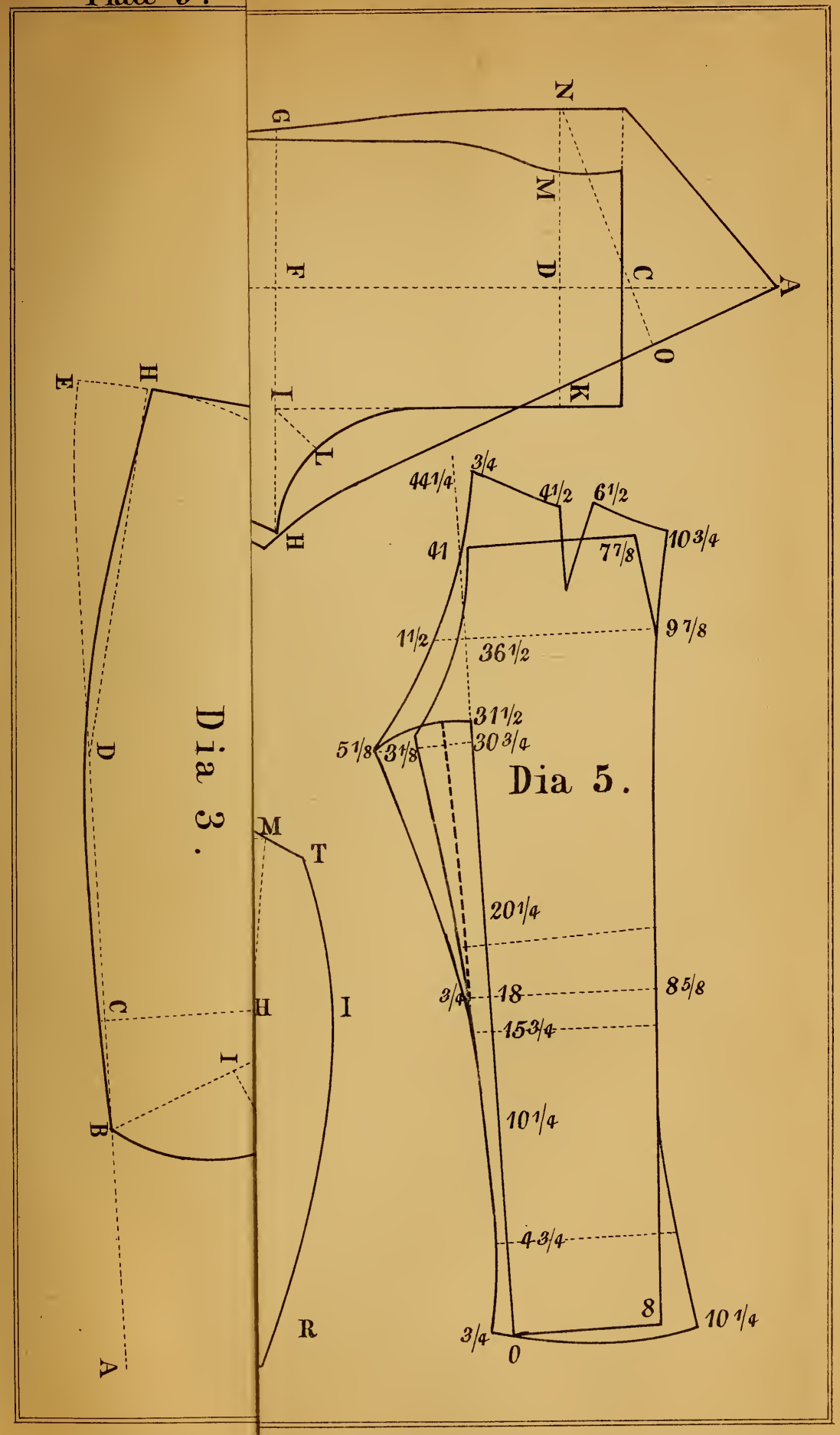




\section{Plate 9.}

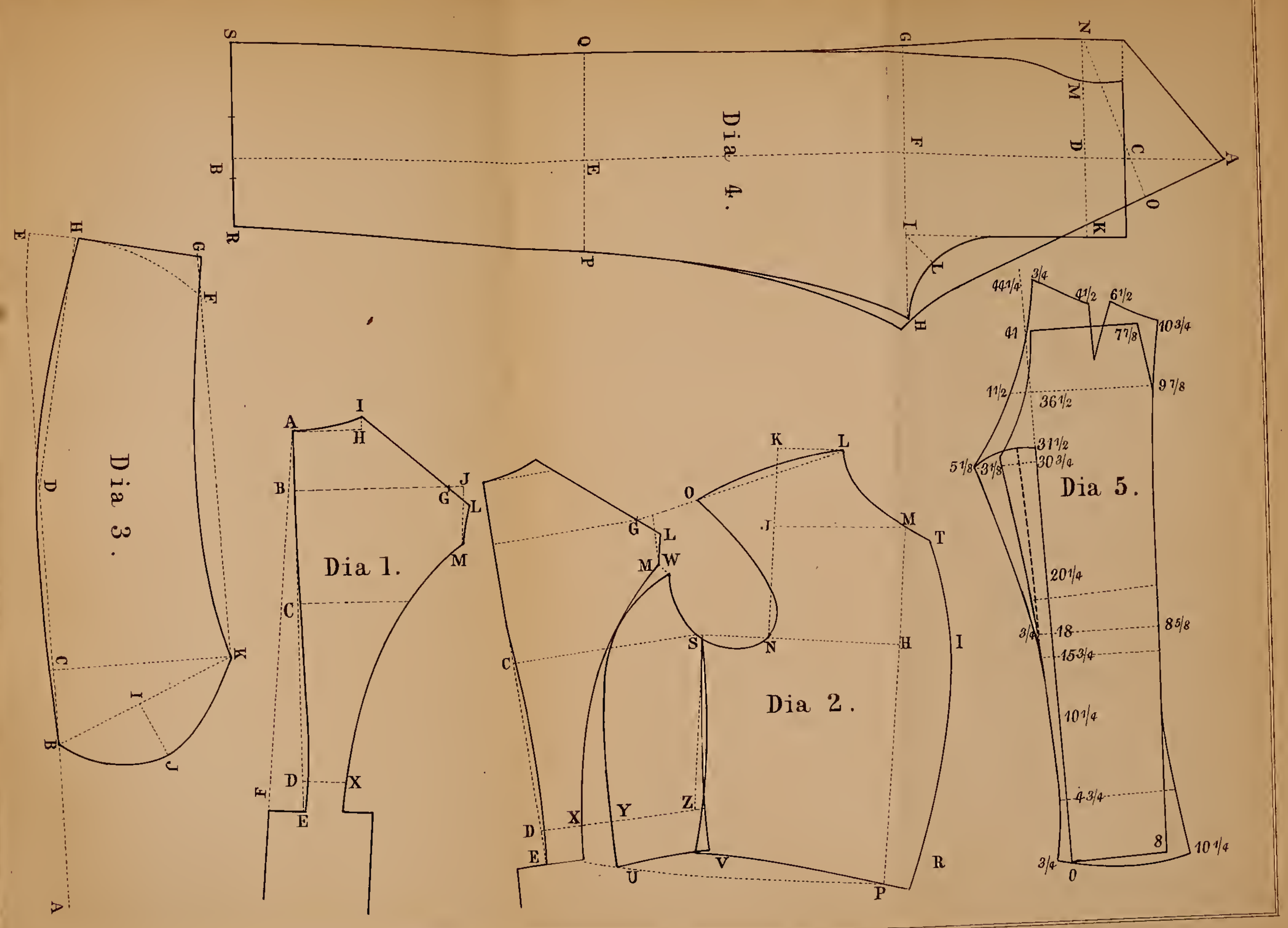



The following are the instructions for drafting the System :

\section{DIRECTIONS FOR MEASURING.}

From the nape of the neck to the hollow of the waist (termed the natural waist length), $16 \frac{1}{2}$, continue to length of waist required by fashion or fancy, 18 ; thence to the full length of skirt. From back seam to width required $7 \frac{1}{2}$; to elbow, 21 ; to full length of sleeve, 31 ; take the measure of the scye $\left(16 \frac{1}{2}\right)$, and then the width of sleeve at elbow and wrist. The breast, 18 ; waist, 15 ; and shoulder measures, 27 , follow, all to be taken under the coat.

\section{DIRECTIONS FOR DRAFTING.}

Dia. 1, Plate 9: The Back.-Mark the line A F the full length of the garment. From $\mathrm{A}$ to $\mathrm{E}$ the fashion length of waist. Mark in from the line $\mathrm{A} \mathrm{F}$ one inch and a half to $\mathrm{E}$ for back tacking. Then draw the line $\mathrm{A}$ to $\mathrm{E}$, and on this line mark from $\mathrm{A}$ to $\mathrm{B}$ one-sixth of the natural waist length $\left(2 \frac{3}{4}\right)$; from $\mathrm{B}$ to $\mathrm{C}$ onethird of the circumference of scye $\left(5 \frac{1}{2}\right)$ and $A$ to $D$ the natural waist length. From A to $\mathrm{H}$, square with the back seam, mark one-sixth of breast (3), and, square with this line, mark upwards to I five-eighths of an inch, and curve from A to I for the top of back. Square B to J, and mark at G one inch more than one-third (7), and farther on to $J$ the desired width of back. Draw the line at $\mathrm{C}$ square with the back seam. Draft the shoulder seam from I through G to L. Draw the line J M square with $\mathbf{J} \mathbf{B}$, and mark the width of back scye to taste, throwing it slightly forward, as seen at L. D to X, two inches, or to taste, draw a graceful curve from $\mathrm{M}$ through $\mathrm{X}$ to waist seam, hollow the back seam at natural waist, add at least one inch for plaits, and complete the back.

Dia. 2, Plate 9: The Forepart.-Square with the back at point C, draw the blade line C S, half an inch less than half the breast measure $\left(8 \frac{1}{2}\right)$, and at $\mathrm{D}$ the natural waist line $\mathrm{D} Z$. Take out between $\mathrm{X}$ and $\mathrm{Y}$ one-twelfth of the natural waist length $\left(1 \frac{3}{8}\right)$. Measure the width from D to X, place that quantity at point $\mathrm{Y}$, and make point $\mathrm{Z}$ one-third of waist measure (5). Draw S Z, and square base line $\mathrm{S} \mathrm{H}$ by S Z. From S to N one-sixth of breast (3). Make $\mathrm{H}$ the breast measure from $\mathrm{C}$ (18), and from $\mathrm{H}$ to $\mathrm{I}$ two and a half inches. Square with $\mathrm{N}$ $\mathrm{H}$ mark the front balance line $\mathrm{N} \mathrm{K}$. From $\mathrm{N}$ to $\mathrm{J}$ one-third of circumference of scye $\left(5 \frac{1}{2}\right)$, and from $J$ to $\mathbf{K}$ one-sixth of breast (3). From $J$ to $\mathrm{M}$ draw the gorge line, and by it square the line M H P through the point $\mathrm{H}$. Draw from $\mathrm{K}$ to $\mathrm{L}$ the position line. Mark $\mathrm{L}$ one-sixth of the breast from $\mathrm{K}(3)$, and draw the front shoulder line from $\mathrm{L}$ to $\mathrm{G}$. Mark on this line the 
length of shoulder seam of the back as at $\mathrm{O}$, and add on about three eighths of round above the line, as shown on the diagram. Make the bottom of the side seam of back a centre, and sweep a line from the side seam point. On this line mark to $W$ half an inch. Draw the scye from $\mathrm{O}$ through $\mathrm{N}$ and $\mathrm{S}$ to $\mathrm{W}$. Draw the side seam from $\mathrm{W}$ to the bladebone line, and from there through $\mathrm{Y}$ to $\mathrm{U}$; make the top of side seam a pivot, and cast the length at $U$ from the bottom of back. Draw the gorge from $\mathrm{L}$ through $\mathrm{M}$ to $\mathrm{T}$. Make $\mathrm{D}$ to $\mathrm{R}$, when in a closed position, one inch more than waist measure (16). H to $\mathrm{P}$ one inch and half longer than distance from $\mathrm{C}$ to $\mathrm{E}$ on the back, or to measure. Draw a straight line from $\mathrm{U}$ to $\mathrm{P}$, and then draft the waist seam, hollowing it one inch at V. Make M to $\mathrm{T}$ one inch, or to taste, according to the break required, draw the front line from $T$ through $I$ to $R$, draw the side body seam, adding on a little spring for hip below the natural waist as diagram, and complete the forepart.

Dia. 3, Plate 9: The Sleeve.-Draw the perpendicular line A E. Mark from A to $\mathrm{B}$ the width of back, $\mathrm{A}$ to $\mathrm{C}$ one inch less than 2-3rds of the breast measure (11), A to D the length to elbow, and to $\mathrm{E}$ the full length of sleeve. Make D a centre, and cast the curve from $\mathrm{E}$ to $\mathrm{H}$. Draw $\mathrm{C} \mathrm{K}$ square with $\mathrm{C} \mathrm{D}$ $\mathrm{E}$; and make $\mathrm{C} \mathrm{K}$ half the scye measure $\left(8 \frac{1}{4}\right)$, and then draw the oblique line from $B$ to $K$. Divide the distance at $I$, and square to $J$ one-sixth of the scye measure. Form the sleeve head by drawing the curve from $\mathbf{B}$ through $\mathrm{J}$ to $\mathrm{K}$. Draw the line $\mathrm{K}$ G square with the line $\mathrm{K} \mathrm{C}$. Mark from $\mathrm{G}$ to $\mathrm{H}$ the width of sleeve required at the hand; now place the angle of the square at $\mathrm{H}$ with the right arm of the square intercepting $\mathrm{D}$ at the elbow, and draw the lines $\mathrm{H} \mathrm{G}$ and $\mathrm{H} \mathrm{D}$. Hollow the fore-arm to fashion; also add on to elbow the quantity either to measurement or to fashion, and draft the hind-arm seam.

\section{F. W. HOLSTON'S SYSTEM.}

The introduction to some works raises our expectations that we have before us a system of a superior character to the general number of methods; but when we come to examine and test them, we frequently find a great difference between the promise and the performance. When we take up a work professing to teach an anatomical system, and the author states in his introduction that "the study of anatomy would enable him (the tailor) to understand the true proportion of the human frame, the cause of the various disproportions, and the true scientific mode of treating them," one is led to anticipate some really scientific work. Further on the author says that he has "been enabled to produce the present work simplified to a 
degree, the why and the wherefore carefully excluded. This statement excites one's surprise, for really the crux of a good system is that the why and the wherefore are present to the minds of the students, so that their study is not the blind following of a teacher, but the study and practice of sound principles which command their respect by the reasonableness of the theory and the tests of experience.

The Anatomical System for every description of coats, vests, trousers, \&c., based on purely anatomical principles, and which, according to the title page, "may with truth be termed Cutting by Sight," is, in fact, only a humble imitation of Dr. Wampen, but without those teachings of principles which convince and satisfy the enquiring and logical mind. This system, by F. W. Holston, is explained by a series of diagrams from $\mathrm{A}$ to W. These diagrams may be increased or diminished in size according to a printed scale. No quantities are given on the diagrams, but the points are indicated by letters. This printed scale is in fact a substitute for graduated tapes, with the disadvantage that it would soon wear out in the cutting room if used.

The author follows Dr. Wampen in taking the height measure from nape to heel, and the following remarks show that he endeavours to imitate the Dr.'s teachings: "The breast measure must be taken for all widths, the corresponding height measure for all depths; for instance, suppose the customer has bulk sufficient for a man six feet high and he only measures five feet, the measure for the five feet man must be taken for all depths, and the breast measure corresponding to his breast referred to for all breadths; thus, however short the man, his scye will never be too low; every point is obtained on purely anatomical principles." Yes, but his scye will not be low enough, which the author would have known had he studied more deeply Dr. Wampen's teachings.

\section{H. B. MORRIS'S SYSTEM.}

Some authors rush into print without any adequate reasonwithout considering whether they have anything really to teach. The notion that they have something different to that which has already been placed before the trade or the public is a sufficient incentive; or else they set themselves up as teachers, and therefore require to have something different-to qualify themselves as teachers-this something being an improvement or otherwise. If this is not so I am at a loss to account why authors of the stamp of $\mathrm{Mr}$. H. B. Morris issue such works as his Tailor's Self-Instructor. His method is simply a breast measure system, without any special feature to commend it before a score of breast measure systems which have preceded 
it. The model for a proportionate figure is well drawn, but the method by which it is drafted is to my thinking uncertain and unsatisfactory.

The second edition of the Art of Scientific Cutting, by B. H. Morris, is a work of a very different character to the Tailor's Self-Instructor. I presume this work is by the same author, and that the placing of the initials is simply a printer's error. There is no comparison between the two works. The latter is a great improvement in every respect upon the former one, for it is a work of a comprehensive character, displaying no small amount of practical and scientific knowledge. The primary system is purely a breast measure one, but when we arrive at the usual difficult point in all breast measure systems, where principle pure and simple utterly fails, and where some arbitrary arrangement or modification becomes absolutely necessary, our author resorts to the use of two breast measures as he calls them. One the actual circumference of the chest, the other measure corresponding to the height of the customer. He says, "We will suppose we have a short, stout man to cut for, say 44 breast and only $5 \mathrm{ft} .6 \mathrm{in}$. in height. In this case we use 22 to cut widths by, and find another breast measure proportionate to the height to cut lengths by. The breast measure proportionate to $5 \mathrm{ft} .6 \mathrm{in}$. is 35 , therefore in this case we use 22 (to draft the widths by) and $17 \frac{1}{2}$ to draft (the depths by) the system." A plan is also given whereby admeasurements could be applied to the system. In addition to the usual garments required of tailors for which he gives methods to cut, he has added diagrams showing the alterations required for the various disproportions of the human figure.

The author shows that he had the advantage of a knowledge of the works of the more eminent of his predecessors, and that he was willing to avail himself of their knowledge where his judgment coincided with them. Altogether the work contains some amount of useful knowledge, which is stated in plain comprehensible language.

\section{JOHN JONES'S SYSTEM.}

A contribution was made to our trade literature in 1872 by Mr. John Jones, of Liverpool, in a work entitled "Sartor Novus: A Scientific Method of Cutting Coats, Vests and Trousers." One is predisposed in favour of the work by the unpretending modesty of the Introduction. The system is a shoulder measure system, and is drafted by four extra measures: 1. A measure to get the height of shoulder. 2. Hip measure, socalled, taken from neck to the hollow of waist. 3. Blade-bone measure, i.e., lower shoulder measure : and 4th, second shoulder 
measure, i.e., upper shoulder measure. The idea endeavoured to be embodied in the system is best explained perhaps in the author's own words: "The idea suggested itself to my mind of dividing the shoulder measure, and governing its application by the hip measure."

The method is original, but rather complex, and as such is open to criticism, but no doubt the author will have since simplified it by dint of practice and observation.

The last fifteen years have been the most fertile of literary activity in the history of our trade. Although it is not within the scope of my purpose to enter into a critical examination of the merits of the various productions during this period, and this for obrious reasons, still, I should fail in my intention, and render myself liable to misrepresentation, or misunderstanding, if I omitted to express my high appreciation of the labours of my contemporaries. I purpose, then, to give a brief notice of the various works published in the period referred to, and which I have omitted to notice previously. I may have been led into errors of omission or commission by inadvertence, but certainly not by purpose, as my sincere wish is to duly record my appreciation of every attempt to contribute to the thought and culture of our trade, even when I am not able to agree with the tone, manner, or the kind of contribution.

Among modern authors who have most distinguished themselves is Mr. Thos. Darwin Humphreys, who, I believe, has contributed more material to the literature of our trade than any other writer during this period, whether considered as a contributor to our journals, as author, or editor. This gentleman, as early as the year 1848, published the "Cutters' Guide" in English and Welsh; and in 1860 a collection of trousers systems, with many illustrations, and ample criticisms of the various principles on which they were constructed, displaying an amount of knowledge of the subject which at once stamped a character on the writer. Since the publication of this work, his pen has been most prolific. Besides the editing of two periodicals, he has written and published "Coat Cutting," by T. Darwin Humphreys, in 1867 ; "Scientific Cutting," by Dr. Humphreys, in two parts ; "Vest Cutting;" the "Student's Guide to Systematic Trousers Cutting;" the "Student's Guide to Practical and Scientific Cutting;" "Trousers Cutting;" the "Polytechnic Coat System" and the "Polytechnic Vest System;" the "Academy Trousers System;" and "Coat Cutting Practical and Critical," issued in 1887.

The whole of this writer's works form a monument of the industry, resource, and intelligence of the author.

The name of Mr. John Anderson, of Edinburgh, is one well known in the trade, principally through his very striking and 
original contributions to the periodical press. Originality of thought and high purpose are not so common amongst our authors as to be passed by without notice or eulogy. It was the renown of his ability that caused some degree of expectation to arise, when the publication of "The Tailor's Complete Instructor in Cutting," by John Anderson, Edinburgh, was announced in 1876 . This work was equal to the reputation of the author, but the language used was too scientific and abstruse to suit the general acquirements of the trade, and, besides, it did not contain a practical system which might and would probably have commended itself to, and obtained the patronage of, the trade. A second volume has not yet appeared.

A very important work on practical tailoring, entitled "Garment Making," the joint production, I am informed, of Messrs. Charles Green and John Williamson, was published, containing the most minute detailed instructions how to make every kind of garment required of tailors. The instructions, although so minute, are written as clearly and precisely as it is possible to give them. I can only speak in the most unqualified terms in praise of the production, and I consider I am a competent and unbiassed judge; for in the year 1869, I commenced to write a series of papers on the same subject in the West-End GazeTte, so I know something of the difficulties attending the composition of such a work. This book ought to be in the possession of every tailor, and I know of no more suitable or necessary present to every apprentice to our trade than this work. It must become, from its uniqueness and quality, a classic in our trade literature. To Mr. John Williamson is also due the credit of writing "Our Cutting Class, a series of elementary lessons on the principles of Cutting," the "School of Art Examinations," and the "Student's Preparatory Instructor and Guide."

I have in a separate chapter noticed our periodical press, but this alone does not fully show the power and influence for good that it has wielded. For a variety of works by various authors has been the outcome of its labours; many of these have been in the form of essays, the result of prizes which had been offered. It would be superfluous to mention more than the principal ones. Mr. Robert Williamson, of Peebles, has distinguished himself as the author of two first-prize essays on "Coat Cutting" and "Trousers Cutting"; Mr. Falconer wrote "The Art of Cutting by Model Patterns"; Mr. Z. W. Shaw "The Art of Trying On" ; and Mr. W. L. Dobson "Cutting by Block Patterns," published in 1884. The late Mr. J. Hepple also published "A Condensed System of Cutting to Measurement," which reached to a third edition.

Another contributor to our trade literature is well worthy of mention. I refer to Mr. Thomas Hogg, who in 1871 published 
"Belfast's System for Trousers and Breeches." This on its appearance was rather severely criticised, yet it had, I understand, a large circulation, which induced the author afterwards to publish a "Coat and Vest System," and a "System for Drafting Ladies' Garments," which were also well received by the trade.

A direct measurement system of cutting has been issued by Mr. P. J. Vetter, under the heading of "The Art of Practical Cutting, adapted for self-teaching." It is published in two volumes, and is the work of a good practical tailor; this I can say with confidence, for he was employed in our establishment in both capacities, as workman and foreman. This work being the production of a practical tailor and cutter, is in my estimation a valid recommendation.

I find the names mentioned of some systems of cutting which I have not been able to examine. I refer to the "New System of Drafting," published by L. Phylocky, and Salisbury's work on "Measurement and Drafting," and also works by B. Tilley, and G. Withey.

A gentleman, Mr. J. F. Davies, who is well known to the readers of our periodical literature for the clearness and incisiveness of his articles, has written and published the undermentioned works since 1875: viz., "A Review of Ladies' Garment Cutting"; "The Reliable Coat, Vest, and Breeches Systems"; "Reliable System of Ladies' Garments"; "Utility's Trousers System"; "Pioneer System for Cutting Cloaks, Dolmans, \&c."; "Conformateur"; "Private Ladies' Cloak and Ladies' Vest"; "Scientific System of Dress Cutting"; "Cyclopœedia of Alterations"; "The Student's Guide"; (1) "Breast Measure"; (2) "Admeasurement"; (3) "Threeseamers and Overcoats"; a work on "Disproportion"; and, last but not least, "A New Ladies' Book," this work being of a comprehensive character, and containing a large number of plates. This list comprises seventeen works. The immense amount of labour, time, and thought required to produce these works, can only be fairly appreciated by those who have been engaged in literary work of a similar character.

One of the latest, if not the most recent author of works on cutting is Mr. T. H. Holding, who has published four works in a very short space of time. The first contains a coat system founded on the breast measure principle; the second, trousers and vest systems; the third, systems for producing ladies' garments; and the last, but not the least important, a concise work "On Alterations," giving practical instructions for making the necessary alterations to various garments which tailors seem "heirs to." These various works are of such recent production that no doubt they are in the hands of those of my readers who take an interest in our trade literature. 


\section{MEASURING MACHINES.}

No history of the Art of Cutting would be complete without some notice, however short, of the machines which have been invented for measuring the human body, with the view of applying their results for the production of garments. These machines have varied much in their character, although the same in purpose. Some are more ambitious and extensive in their aim than others. The greater number are intended to take measurements of the surface of the upper part of the body only, with the view of being applied. Some few have a wider scope, and are designed to take the measurements of the upper and the lower parts of the body. Another class has been produced, with the two-fold purpose of taking the measures and forms, and modelling the draft by the direct action of the machine.

It may be stated that no machine has yet been invented which has met with the support of the trade, or which has been in any sense in common use.

The cause of these failures most probably is the great difficulties the inventors have to overcome, and which up to the present have been insuperable. It seems to an ordinary mind almost impossible to take an accurate measure of the surface of a complex yielding body, with its many convexities and concavities, and to transfer this measure accurately to a plane surface. Although this purpose has not yet been accomplished, it is no proof that it cannot possibly be done; and no doubt men of a mechanical turn of mind, and possessed of the inventive faculty, will continue to endeavour to overcome the many difficulties that seem inseparable from the project.

It is not my intention, nor within my province, to do more than simply note the fact that numerous inventions have been from time to time introduced for the purpose of accurately measuring the body, and also to record the further indisputable fact, that no inventor has yet succeeded in producing a machine which has been used by any considerable number of cutters. An inventor might possibly use a machine of his own invention successfully, but that is not sufficient to commend it for general adoption by the trade. Any enquirer who will visit the Patent Museum and examine the specifications deposited there, will be surprised at the mechanical ingenuity displayed by many of the inventors of measuring machines, and will smile inwardly at the folly, vanity and presumption of others. It would be invidious to particularize any one machine, or set of machines, without giving a complete list. One thing is evident, that the same principle underlies all these futile efforts, and that it has not yet been demonstrated as practicable. 
If it would not be thought presumptuous on my part, I wish to utter a word of caution or advice to all inventors of measuring machines. I should like to tell them with all the emphasis that language is possible, that before devoting their time, thoughts, and money to mechanical inventions of this nature, that they should, in duty to themselves, ascertain by enquiry or examination, what machines of a similar kind have been invented, and wherein they have failed. It would save them many heartburnings and waste of time and effort.

\section{OUR TRADE PRESS.}

A very important factor in our modern history, and in the dissemination of knowledge pertaining to our craft, is the expansion of our periodical literature within the last quarter of a century. Up to that period there had only been two or at the most three journals of the kind published in England. At the present time there are five journals, two of which are issued monthly and weekly, and the remaining three monthly only. The amount of their circulation has also enormously increased, so as to be beyond any comparison with that of the journals issued previously. These journals are conducted with a considerable amount of literary and artistic skill, and contain a large quantity of scientific and practical knowledge, as well as detailed illustrations and explanations of the most fashionable costumes of the period.

By their means many thoughtful men have been enabled to communicate their valuable ideas to our craft; theories have been explained and examined, and the results of extended practice and repeated experiment have been made known. At no period since the existence of our trade has there been such a sound and extensive knowledge of its principles and practice spread abroad, resulting in the fact that our fellow cutters are more intelligent and capable than was possible for their predecessors.

\section{THE "CYCLOPADIA OF BRITISH COSTUME."}

The earliest specimen of a purely English Fashion Journal which has come under my notice is the "Cyclopædia of British Costumes," published by Mr. W. Hearn. The first number must have appeared in the spring of 1823 , according to the date of the number before me. It was published halfyearly - spring and winter. It contained five plates of costumes and two plates of naval dress, and had thirteen pages of letterpress descriptive of the illustrations. The plates were coloured, and presumably correct representations of the dress of the period. No method of cutting any garment was given; it was simply a journal of gentlemen's fashions, and nothing more.

The trade is indebted for this journal to the industry and 
intelligence of Mr. Hearn, of whose valuable contributions to the literature of our trade I have already spoken. This journal adds another claim by him to our gratitude and kindly remembrance of the departed trade worthies. The present and succeeding generations of thoughtful tailors, will, I hope, treasure their memories.

Two specimens of the dress of this period are copied from this magazine, and printed on Plate I.

\section{THE “GENTLEMAN'S MAGAZINE."}

The "Gentleman's Magazine of Fashions, Fancy Costumes, and the Regimentals of the Army," must have appeared in 1828, according to a volume in the British Museum, dated January, 1830, Vol. 3. Although giving two plates of fashion each month, its contents prove that it was more intended for the public than for tailors. For instance, besides the description of the plates of fashion, the articles are: "Talk in London;" "Plays, Playhouses, and Players." The tailor is only remarkable by his absence. A specimen of the description of Fig. 1, in Vol. 9, January, 1836, will suffice: "A Walking Dress.-A claret great-coat, double-breasted, with fur collar and cuffs, the skirts are lined with chequered frieze, and the coat is of napped Harrington; the pockets are put in with a slashed welt, and the edges must of course be bound. A light blue lappeled coat, double-breasted, with gilt buttons, and buttoned up to the neck, is in excellent taste both in colour and style. The trousers are of lavender buckskin, of moderate width with gaiter tongues at bottom." A simple reference is made to the tailor by the announcement that patterns may be had of W. Chevin, Tailor, 13, Vine Street, Regent Street. Diagrams were sometimes given of the garments, but no quantities to aid the tailor. Occasionally full-sized diagrams were also given. The styles of dress at this period differ so considerably from those of our own time that they appear to us now as caricatures; still we must remember that probably fifty years hence our descendants will gaze with wonder and surprise on, to them, the extraordinary habiliments of the present age. These volumes must in some sense have been intended as guides for tailors, or else the editor would scarcely have given model patterns. What seems to us now so remarkable is that no method of cutting is given or even alluded to in the whole eleven volumes. This fact supplies further evidence of the paucity of knowledge of the Art of Cutting during this period, likewise the small demand by tailors for that article, or else the publisher and editor would doubtless have been shrewd enough to supply it.

The second series of the "Gentleman's Magazine" appeared on January 1, 1839, and now we have a veritable magazine of 
fashion, for it is illustrated with a monthly plate containing 10 figures dressed in the height of fashion. The colours and the forms appear to us now absurd and ugly, but in those days they, were the correct ton. The engraving is entitled "The Tailors' Monthly Pattern Card of Gentlemen's Fashions, approved of by London fashionables of the clubs of St. James's Street, and decided upon by a committee of celebrated London fashionable tailors." There is a letterpress description of the plates, and observations on gentlemen's fashions, but they seem more intended to instruct gentlemen than to help tailors. With the number for December, 1839, is given full-sized diagrams of a frock coat and waistcoat. These were labelled as Bell's scientifically practical patterns. Tailors seem to revel in high-flown names, their appropriateness being seemingly of a secondary consideration, but these diagrams prove that the interests of tailors were not entirely ignored. The magazine was continued, but from 1840 to 1847 without diagrams.

In December, 1847, an improved series appeared under the auspices of Mons. Louis Devere. Diagrams were reintroduced, illustrations of fashion with descriptions were given, and also some instructions for drafting and cutting out garments. This was, from our point of view, a great improvement, for it became a journal really devoted to tailoring, and was very similar in style to its present form.

This is indisputably the oldest English Fashion Journal for tailors in existence, as it is a continuation of the 1828 edition, of which Mr. John Browne Bell, of 229, Strand, and Craven Street, was the founder and sole proprietor up to December, 1847.

\section{THE “LION."}

On the 1st of May, 1845, appeared the first number of "The Lion," a journal of the newest gentlemen's fashions, published in London and Paris every month. The prevalence of French fashions is here distinctly shown. The coloured plates are undisguised French productions; the title of "Le Lion," and the instructions at the foot of the plate, are in the French language. The London edition was published in Paris, and the article headed "Fashions," is announced as translated from the French. This journal contained eight pages of readable matter, a plate of diagrams, and a coloured plate of French fashions. Various systems were given for constructing garments, and special articles on making up were inserted.

The proprietors of this journal also issued a quarterly publication, called "The Artist." In autumn and spring large coloured plates were published, containing eighteen figures. This plate, we are informed, was engraved, printed, and coloured in Paris. Three sheets of patterns accompanied it. 


\section{THE “TAILOR'S ADVOCATE."}

A weekly journal, devoted to the interests of the trade, called "The Tailor's Advocate," was published in 1845, under the direction of the executive committee of The United Tailors' Protection Society of Great Britain. The following sentiments, extracted from No. 3, are highly commendable. It says: "Association has chiefly failed among the industrious orders because it has unthinkingly been made to breathe only a pecuniary, when it should have breathed a moral purpose. But make it the emblem of fraternity, of generous aims, of just endeavour, and association, from being felt as an obligation, will become a pleasure and a pride. The Protection Society offers the hand of fraternity to all its brethren, and asks only justice between the employer and the employed."

\section{"MINISTER'S GAZETTE OF FASHION."}

"Minister's Gazette of Fashion " was established on May 1st, 1846 , and has continued to be published under the same auspices up to the present. Messrs. Minister assert, in their introduction to the first number, that they had been publishers of a somewhat similar work for twenty-six years. They must have alluded to "The Report of Fashion," a bi-annual plate of fashions which they published. The Gazette contains eight pages of letterpress, a sheet of diagrams, and three plates of fashions. It has been conducted from the first in a manner highly creditable to the proprietors and advantageous to the trade. It excelled its contemporaries by admitting to its pages systems and articles from various correspondents, which from the commencement have added considerably to its value and influence.

The fashion plates were imported from France as well as the fashions. English taste, it seems, had not developed to such a degree as to require to be worthy of illustrating. But when the trade became dissatisfied with the highly-coloured and extravagant character of the French fashions, and another journal (the "West-End Gazette") had introduced and adopted lithographic illustrations of English costumes as distinguished from the French-this journal was the first to follow its example, a laudable practice, which is still continued.

\section{THE "LONDON WEST-END GENTLEMEN'S FASHIONS."}

In September, 1861, appeared the "London West-End Gentlemen's Fashions," edited by a Metropolitan cutter, under the superintendence of a committee of fashionable tailors. Price, one shilling. Contents : two coloured plates, sheet of diagrams, a pattern, and four pages of letterpress. Only one number was published. It purported to be a continuation, but the publishers state this was an error. 
THE “WEST-END GAZETTE."

The first number of the "West-End Gazette" was published in October, 1861. It was edited by Mr. Thos. Gilham (late foreman to $\mathrm{H}$. Poole \& Co.). It contained three pages of letterpress, a sheet of diagrams, two coloured plates, and a pattern. It had but a small circulation under his guidance. The copyright was purchased from him for the Metropolitan Foremen Tailors' Society, and his last number appeared in June, 1862 .

In the early part of 1862 , the copyright of the "West-End Gazette" was offered to and purchased by the Society. On July 1st, 1862, appeared the first number under its auspices. It comprised only four pages, three of letterpress and a title page, a sheet of diagrams, and two coloured plates of gentlemen's costumes. These plates of fashion, like those of the other journals, were imported from Paris, where they were produced wholesale and retailed to any number of journals, thus supplying them at a much less cost than it was possible to produce them specially. But as one of the principal objects of the journal was to illustrate genuine English fashion, the Editorial Committee determined to make an effort in this direction. The first attempt made was to send over to Paris photos of garments worn by members, and to have a plate specially designed and executed for their journal. This first plate was issued in March, 1863. The outcome of this was that the cost of the plate alone was more than that number of the journal realised. This result prevented the plan being carried out monthly, but it was determined that a special plate should be produced each season, so the next plate accordingly appeared in November, 1863.

Not only were the styles of garments issued in the "WestEnd Gazette," in common with the other journals, French fashions, which offended our national pride, but the colourings were so tawdry and unsuitable that no English gentleman would think of donning such glaring garments. Although the committee were not satisfied that they had not succeeded, they issued special plates in October, 1864, and April, 1865 , but it was not until Uctober, 1865 , that they were able to issue a special uncoloured lithographed plate. This first attempt was so far satisfactory, that they were induced to instruct M. Guichard, a French artist residing in London, to design and lithograph a plate of boys' figures, which they gave as an extra plate in January, 18t6. Unfortunately this was so far inferior, in artistic style, to the Parisian plates that the series could not be continued. Undeterred by this failure, the committee arranged with a Parisian artist to design and lithograph two special plates monthly for the "West-End 
Gazette." The first plates were published in January, 1868, and were so successful that lithographic plates have been continued since that time. The French artist died, and unfortunately his successor was not equally skilful, so the committee determined to make an earnest effort to obtain an English artist. After many unsuccessful attempts, they succeeded in engaging with a gentleman, whose first production appeared in the number for May, 1869. The designs have continued to be executed by the same artist, and lithographed by the same lithographer up to the present. I have entered thus fully into detail because this is the history of the development of English lithographed fashion plates, and the disuse of coloured French fashion illustrations. Other journals have followed this example, and now lithographed plates are the usual means of illustrating English fashions.

The "West-End Gazette," being the property of the Metropolitan Foremen Tailors' Society, is a special means of intercommunication between the members of this large Society. It has always endeavoured to keep a high standard of excellence, both as regards artistic and literary merit, and to avoid all personal controversy.

Since March, 1886, it has been enlarged to sixteen pages of letterpress. It also contains two specially designed plates of English fashions and a large plate of diagrams.

\section{THE “TAILOR AND CUTTER."}

The "Tailor and Cutter" was first started in London in the year 1866-the year before the great strike in London. The journal, under another name, was originally started in Glasgow, in connection with a Scotch movement among the tailors there, the editor and proprietor having previously written a pamphlet entitled an "Earnest appeal to the Journeymen Tailors of Scotland," with the result, that a national conference of the tailors of scotland met in Glasgow, at which it was resolved to publish a journal for the advocacy of the reforms which had previously been sketched forth in the "Earnest Appeal," to be edited and conducted by John Williamson. In the same year Mr. Williamson removed to London and started the "Tailor," its object being to assist the movement in London for the improvement of the position of the workmen.

After the strike had failed, and the agitation had cooled down, the editor introduced simple lessons in cutting, and changed the name of the journal to the "Tailor and Cutter"; so that from being a journal devoted exclusively to the interests of the workmen, it has developed into a journal for plates of fashion, for teaching the science of cutting, and for the advocacy of all movements connected with the elevation of the trade, \&c. 
This journal has a deservedly large circulation both at home and abroad.

\section{THE “SARTOR."}

A journal devoted to fashion and cutting, called the "Sartor" was brought out in November, 1870 , by Mr. Charles Green. It was a weekly journal, price $3 \mathrm{~d}$. Each number contained six pages of well-printed matter on toned paper. It gave also a lithograph plate of two figures, and a pattern. This journal was conducted with considerable ability, but was discontinued in March, 1872. It contained much useful practical instruction, which reflected great credit on the editor.

\section{THE " RECORD OF FASHION."}

The first number of the "Record of Fashion" appeared in January, 1876, it being founded by Messrs. T. D. Humphreys and Charles Green. The last-named retired from the proprietorship on January 1st, 18x0, Mr. Humphreys still continuing the editorship. It was published weekly, and also in monthly parts. It was conducted with a considerable amount of ability. A large quantity of varied information was published in its pages, the fertility of the brain and pen of the editors being not the least remarkable feature of the publication. Numerous diagrams illustrated the varied systems, and illustrations of costumes and patterns of garments were amongst its attractions.

When Mr. Humphreys vacated the editorial chair in January, 1884, he was succeeded by Mr. T. H. Holding, who is conducting this journal in a very vigorous and able manner. On the change of editorship an additional title was prefixed, and it has since been published as "The London Tailor and Record of Fashion."

\section{"THE TAILORING WORLD."}

Some two or three numbers of a journal entitled "The Tailoring World," was issued in November, 1883, under the auspices of Mr. J. F. Davies, of the "Tailor and Cutter." It was a weekly paper and had a somewhat favourable reception. As Mr. Davies rejoined the staff of the "Tailor and Cutter" he discontinued the publication.

These journals have, thanks to the spread of education, and consequently increased intelligence of our trade, penetrated to the remotest villages, and the most outlandish parts of our kingdom and its colonies; so that no one can calculate the extent and power of their influence. Neither can any one reasonably doubt that the whole trade has been raised, principally by their means, to a greater elevation in the scale of knowledge than it had ever before attained.

These various journals contain a great variety of systems for cutting the different kinds of garments required of tailors, 
some of greater, others of lesser merit. The various principles on which these methods are founded are explained and discussed, and their merits extolled or defects exposed. The more active and intelligent members of our craft often make them the medium to convey their wisest and best thoughts to their fellow craftsmen; so that these periodicals contain a fount of tailoring undefiled, which the earnest and enquiring student may examine with profit and advantage. Any impartial inquirer reading these journals with an unprejudiced mind, and reflecting that they contain articles emanating from the pen of craftsmen, and that they are edited by craftsmen, will, I feel assured, give great credit to the intelligence and capacity of our trade.

\section{CONCLUSION.}

In bringing this historic account to a termination, I am of opinion that we may draw some useful conclusions from its due consideration. To over-estimate the value of the past is as unwise as to despise it. The wise will gather up wisdom from the experience of their predecessors, the foolish or the ignorant alone will either over-value or despise it.

It is with no small degree of surprise that many of us have heard that Cutting by System had not been practised in Europe -and that, I presume, included the civilised world--until within these last three hundred years, and that was in Spain. In France systematic cutting has only been practised a little more than two hundred years, and in England it is less than one hundred years since the first work on cutting was published here. These important facts are intensely interesting from a historic point of view, as they furnish us with starting points from which to commence and pursue our researches.

Being without any system for their guidance, the old tailors were obliged to resort to patterns, which were the results of repeated experiments. We can then easily conceive the great value which was placed upon well-tested patterns, and their being worshipped and looked upon as "gods"-of course in a trade sense.

The first departure from this old practice was the "rock of eye" plan, which we see exemplified in the work by the Society of Adepts, or at most this was the first departure from that rude and ready plan, because the simplest rudiments of a system are to be discovered in it. Between the publication of $\mathrm{Mr}$. Hearn's System and the Society of Adepts' work we have no positive data to form conclusions on. Undoubtedly there must have been systems in use more or less imperfect, and it is very prcbable that few, if indeed any, were thought worthy, or were worthy, of being published. The gap is too great between the 
two for them to have spanned it at once. I am of opinion that the "Old Thirds" system originated about this time. We can very well understand that varied versions of this method were in use; the first would be more or less faulty, improvements were made by first one, then another, but neither of them being sufficiently important to justify the improver to incur the risk and expense of publication. It is, however, possible that various systems were published, but in a pamphlet form, which did not survive the authors, and which were indeed considered then of little moment, although they would have possessed a special interest for us at the present time. Then we come to the important personal testimony of the late Mr. E. Minister, who told me that he saw Mr. Duncan McAra draft a system by "thirds" in 1815, but he never knew of its being published. These seem to me the only rational means of accounting for the non-publication in England of the best known system of cutting in the world. This non-publication is the more remarkable, as I have clearly demonstrated that to English tailors belong the credit of its invention and application.

We next come to the systems published by that veteran tailor, Mr. Hearn. The first coat system he published was a breast measure one; but even at this early period he felt the necessity of obtaining the height of neck by measurement. But the most remarkable fact is that he was the founder of direct measurement systems in this country, which is proved by the publication of his direct measurement system in 1823. To Mr. Hearn must we then accord the honour, according to the statement of the late Mr. E. Minister, of having published the first system of cutting, and, as we have seen also, the first direct measurement system. He was also, I believe, the first publisher of plates of fashions in this country.

Little progress seems to have been made until the year 1840, when Mr. Thomas Oliver, of New York, published his shouldermeasure system in this country. He created some sensation in the Metropolis amongst cutters. His system possessed the charm of novelty; and, besides, it had some sound reasons for its recommendation. But it never took a general hold of the trade, and at the present time is not heard of, and probably is not practised by any cutters; or, if so, by a very limited few.

According to Mr. Madison, editor of the "American Tailor and Cutter," Mr. Oliver was not the originator of the shouldermeasure method. He says : "The upper and lower shouldermeasures, and the blade-measure, were first taken and introduced by Otto Madison in 1827." Mr. Oliver travelled for some time as his agent, teaching his system; after which, he brought out one very similar to it, based on the same measurements.

The next great advance in the art of cutting was the publica- 
tion by Dr. Wampen of a system of cutting based on the application of the principles of geometry to the measurement of the body. He had already published a translation of his German work in 1837, but it was not till after the issue of his improved and simplified system, in 1863, that his system became generally known, and the principles on which it is based understood. The same principles were adopted by the authors of the WestEnd System, and embodied by them in that method, but in a simpler, easier, and more readily comprehended form.

These four principles comprise the foundations of the whole of the systems, published under whatever name. But there is an additional plan, rather than a principle, which is applied indifferently to methods based on three out of four of the abovenarned principles. I refer to the practice of admeasurement, which consists of taking one or several measures to aid the cutter's judgment, and to be applied only to those specific parts which he intended. This practice is in almost general operation amongst the great numbers of cutters I have met.

There is another practice, rather than a system, which is much practised in large establishments. I refer to the plan of cutting by block patterns. The principle which lies at the basis of this practice is, that like causes produce like effects, other things being equal; that is to say, a pattern having fitted a man of a given size and position, it would fit any other man of identical proportions and posture. I have never heard this plan sincerely advocated as the best method for producing garments, but as being the readiest and quickest means to accomplish a great amount of work.

Some estimation of the efforts to instruct our trade may be formed, when I say that since between 1796 and 1872 we have published, to my knowledge, fifty-three coat systems, twentyfour of which are based on the breast-measure principle, four on the direct measurement, five on the shoulder-measure, and eleven on the combination of height and width principles, whilst the remaining nine may be described as miscellaneous.

But this will give but a faint idea of the number of systems produced up to the present, for to the periodical press we are indebted for systems without number; and it is to it that we must look for progress in the future, for there systems are criticised, their defects exposed, or advantages extolled-an ounce of just criticism being of more real worth than a pound of unmerited praise.

Vest systems have received but little attention from the various authors I have read. There is only one, Mr. Cogdon, who thinks "waistcoats are more difficult to cut than coats." In fact, a vest is the easiest and simplest garment we have to cut, and less difficulty is found in its fabrication than any other; 
so authors have wisely given only that attention to it which it requires and deserves.

It will probably be observed that attention has been principally devoted to coat systems; and this for the reason that coats are more various and difficult to produce, and also because there has been a greater number of systems published, and a greater variety of principles employed in their production.

In the earliest works on cutting there are either no systems for cutting trousers, or else they are of the most primitive kind, and the most defective style. Simply, trousers were not then worn by gentlemen, therefore no pains were taken in their production. Breeches was the garment worn by gentlemen and people in general, and to these were the tailors obliged to devote their attention. After breeches we see a variety of nether garments in use. For example, Moschettos, which were similar to Pantaloon Trousers, but made with a slit in the centre of the top side at the bottom. In this slit was inserted a gaiter tongue, to come over the front part of the shoe. Besides these there were the Cossacks or plaited trousers, and the full straight Sailor's trousers. Close-fitting breeches seem to have been the favourite lower garment generally worn by all classes during the introduction of these more novel or fashionable styles.

Pantaloons were worn with Hessian boots; then Pantaloon trousers, which were simply long pantaloons; but when loops or buttons were placed at the bottom of the side seams, they were called Wellingtons. At last we arrive at the trouser's proper. These do not seem to have come into general wear until about the year 1825 .

There can be no question that the trousers is a most difficult garment to produce satisfactorily in every respect ; for all move-ments of the lower limbs are affected by them, such as sitting, stooping, walking or riding. To give facilities for these varied movements, and still to preserve an elegant and fashionable form, is indeed a most difficult task. The old masters used the side line as a starting point to produce their trousers from; the fork was generally produced by proportions of the waist measure. All their systems produced a large fork, straight seat and open legs, consequently possessing the advantages of this style and also its inherent defects. I believe that the late Mr. Minister was the introducer of the central line as a guide to produce trousers. I am not aware who first introduced the front line for a basis to produce trouser's, but I may point out Messrs. Compaing and Devere's well-known method as an instance of what I refer to.

These three bases constitute practically the whole of the bases which are used to construct trousers upon. Some authors 
use proportions of the waist measure, others of the tight thigh measure, but the greater number use proportions of the seat measure for producing the body part of the trousers. But these are the results whatever system is used; the trousers are more or less open in the legs, more or less forward in the body, crookeder or straighter in the seat, and smaller or larger in the fork. The size and style depend on the measurements taken.

The study of the origin and progress of the various methods of cutting should be interesting to our fellow craftsmen. It will show them positively what progress has been really made, by comparing the present state of our knowledge with the past. The imperfect and unreliable methods which sufficed to produce the simple garments worn by our forefathers would be unfitted to construct the complex and artistic productions demanded of the present generation of tailors. Our young fellow craftsmen will discover that increased skill and intelligence are required from them to cater for the wants, whims, and fancies of the present race of clients. With the increased knowledge and more cultivated taste of our patrons, a greater demand has arisen on the practical skill and talent for design amongst tailors. Competition in business is so keen that indolence or unskilfulness will inevitably lead to failure. The young aspirant has therefore every incentive to study and to gain experience, for by their aid alone can he maintain his position, much less can he without it surpass his compeers.

I feel assured that no calm and reflective man can compare the knowledge conveyed in the older works on cutting, and the practices of past years, without coming to the conclusion that great and abiding progress has been made; that a greater amount of information has been spread abroad than was possible previously; and that in the remotest towns and villages there exists a greater amount of knowledge of the Art of Cutting than could have been possible in days gone by. And if this were not so it would reflect seriously on the intelligence of our trade writers and the members of our craft. It is an indisputable truth, and the world knows and acknowledges it, that our craft is intelligent. We can point with justifiable pride to our trade literature as a measure of the intelligence and desire for progress in our trade. It will, I believe, bear favourable comparison with the literature of any other trade which is produced and conducted by craftsmen. This should be an encouragement to us to educate ourselves, and to persevere in the noble course we have hitherto pursued. 
7 

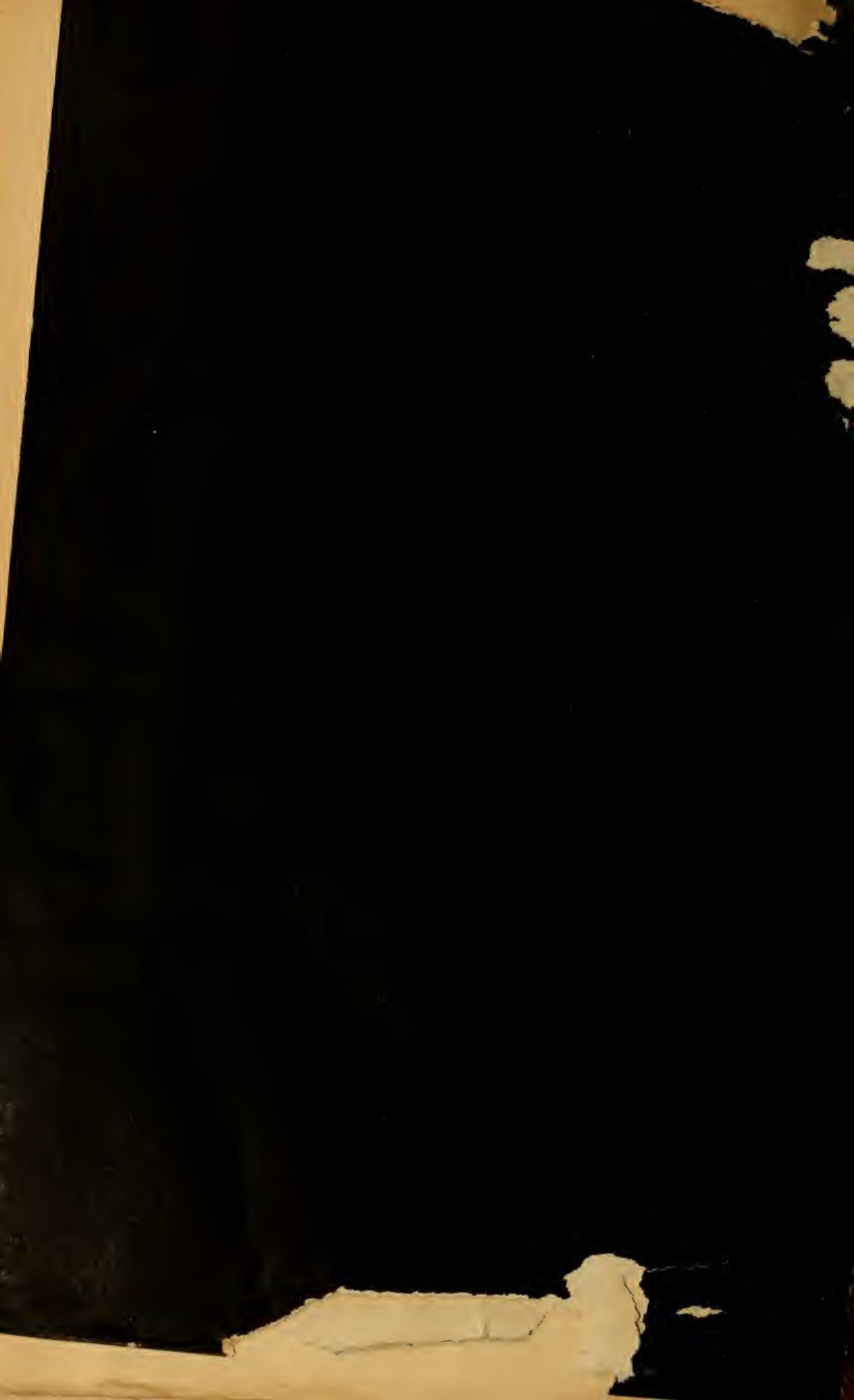


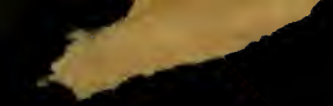

3

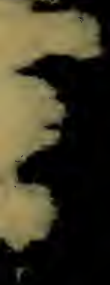

$\rightarrow$ 


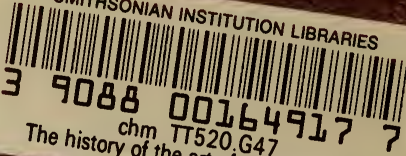

of cutting in Eng 